\author{
Universidade de São Paulo \\ Faculdade de Filosofia, Letras e Ciências Humanas \\ Departamento de Geografia \\ Programa de pós-graduação em Geografia Humana
}

José Eustáquio de SENE

As reformas educacionais após a abertura política no Brasil e na Espanha: uma análise crítica do Ensino Médio e da Geografia

São Paulo

2008 


\author{
Universidade de São Paulo \\ Faculdade de Filosofia, Letras e Ciências Humanas \\ Departamento de Geografia \\ Programa de pós-graduação em Geografia Humana
}

\title{
As reformas educacionais após a abertura política no Brasil e na Espanha: uma análise crítica do Ensino Médio e da Geografia
}

José Eustáquio de Sene

Tese apresentada ao Programa de PósGraduação em Geografia Humana do Departamento de Geografia da Faculdade de Filosofia, Letras e Ciências Humanas da Universidade de São Paulo, para obtenção do título de Doutor em Geografia Humana

Orientador: Profa. Dra. Nídia Nacib Pontuschka 


\section{São Paulo}

2008

\section{Agradecimentos}

A experiência vivenciada no doutorado, desde minha entrada em meados de 2004 até o final do trabalho, foi muito prazerosa e intelectualmente enriquecedora. Foram momentos de muitas leituras, reflexões e troca de idéias; algumas certezas e muitas dúvidas, mas é a dúvida o motor do avanço do conhecimento. Não tenho a pretensão intelectual de esclarecê-las todas, mas espero que este trabalho contribua para o movimento do conhecimento. Durante sua elaboração, convivi com diversas pessoas que, de uma forma ou de outra, deram generosa contribuição para sua execução. Queria que todas soubessem de minha gratidão, e a algumas gostaria de agradecer nominalmente.

O conhecimento se constrói com base em leituras, observações, reflexões, enfim, com pesquisa, com método, com a razão; mas também com envolvimento pessoal, com afetividade, com a emoção, sem o que não se chega ao final de um trabalho. O filósofo Miguel de Unamuno tem toda emoção quando diz:

El hombre, dicen, es un animal racional. No sé por qué no se haya dicho que es un animal afectivo o sentimental. $Y$ acaso lo que de los demás animales le diferencia sea más el sentimiento que no la razón. Más veces he visto razonar a un gato que no reír o llorar. Acaso llore $o$ ría por dentro, pero por dentro caso también el cangrejo resuelva ecuaciones de segundo grado. (UNAMUNO, 1984, p. 27).

Assim, gostaria de agradecer imensamente:

- à professora Nídia Nacib Pontuschka, do Departamento de Geografia da FFLCH-USP e da Faculdade de Educação da USP, pela orientação entusiasmada e pelo generoso apoio ao longo de todos estes anos;

- às professoras Maria Laura Silveira e Lea Francesconi, do Departamento de Geografia da FFLCH-USP, pelas sugestões na banca de qualificação; 
ao Arno e ao Claudivan, pelas sugestões no momento da qualificação, ao Marcos, à Vivian, à Dulcinéia e, mais uma vez, ao Claudivan, pelas sugestivas críticas às vésperas da finalização da tese, e a todos os colegas do grupo, pelos agradáveis momentos de reflexão e debate.

- finalmente, à Mariana e à Sandra, da Editora Scipione, pela revisão do texto.

Gostaria de agradecer também aos colegas espanhóis, que me receberam com tanta atenção, pelos livros e revistas, pelos almoços e cafés, enfim, por me ajudarem a compreender o emaranhado das reformas educacionais que vêm sendo implantadas recentemente naquele país:

- Xosé Manuel Souto González, da Fundació Primer de Maig (Valência) e do grupo de renovação pedagógica Gea-Clio;

- Alberto Luis Gómez e Jesús Romero Morante, professores da Faculdade de Educação da Universidade de Cantabria (Santander) e membros do grupo Asklepios;

- Mercedes Tatjer e Joaquim Prats Cuevas, professores do Departamento de Didática das Ciências Sociais da Universidade de Barcelona;

- e especialmente o professor Horacio Capel Sáez, da Faculdade de Geografia da Universidade de Barcelona, por sua orientação sempre atenciosa e entusiasmada e por me colocar em contato com os colegas espanhóis acima mencionados.

Agradeço imensamente ao Jesús, pela leitura crítica do capítulo em que analiso as diversas reformas ocorridas na Espanha, e ao Xosé, pela leitura do capítulo conceitual - reformas e currículo - e do capítulo sobre as reformas espanholas. As críticas e sugestões de ambos muito contribuíram para aperfeiçoar a análise das reformas realizadas naquele país.

Não posso deixar de agradecer à Lunalva Gomes, do Ministério da Educação (MEC), de Brasília, pela atenção e por me enviar os documentos necessários para o estudo da reforma curricular brasileira; e ao Juan Medina, do Ministério de Educación y Ciencia (MEC), de Madri, pela atenção durante minha pesquisa sobre os documentos das reformas espanholas. 
Por fim, meus agradecimentos ao Rafael e à Camila, pelo apoio logísticofraternal em Barcelona, ao André, em São Paulo, e à Fernanda, mesmo a distância, em Wyndmoor, pelo apoio logístico-filial. 


\section{Resumo}

Esta tese pretende analisar comparativa e criticamente as leis responsáveis pelas reformas educacionais implantadas no Brasil e na Espanha após a redemocratização, período que tem como marco as respectivas Constituições, de 1988 e de 1978.

Como as reformas educativas são um fenômeno complexo e multidimensional, serão analisadas somente do ponto de vista estrutural - atendo-se ao ensino médio - e curricular - atendo-se à disciplina Geografia. Com base nos documentos do Ministério da Educação (Brasil) e do Ministério de Educación y Ciencia (Espanha), procurar-se-á investigar as justificativas, as contradições e os conflitos de interesse político-econômicos e ideológicos envolvidos nos processos reformistas. Serão pesquisadas ainda as divergências epistemológicas e teóricometodológicas subjacentes à modalidade curricular das reformas.

Para tanto, é importante desvendar especialmente 0 conceito de sociedade do conhecimento, uma das justificativas mais recorrentes para tais reformas, além dos conceitos de reforma educacional, currículo, conhecimentos, competências, ideologia, entre outros. Serão discutidos também os conceitos e as categorias da Geografia, especialmente nos documentos brasileiros, procurando desvendar eventuais incoerências e conflitos teórico-metodológicos existentes nesse campo disciplinar.

Para atingir os objetivos enunciados acima, a pesquisa se fundamentará no método de abordagem crítico-dialético. Para sua constituição, serão buscados subsídios na teoria crítica dos pensadores da Escola de Frankfurt, especialmente em Horkheimer e Habermas, e na lógica dialética, particularmente como interpretada por Lefebvre. Com base nos pressupostos desse método de abordagem, é importante verificar se os processos de reforma têm contribuído ou não para a emancipação dos sujeitos - professores e alunos - a que se destinam. Isso exige uma discussão sobre o significado de "emancipação". 
Palavras-chave: reformas educacionais, currículo, ensino médio, Geografia, emancipação. 


\section{Abstract}

The purpose of this thesis is to analyze comparatively and critically the laws responsible for the educational reform implanted in Brazil and Spain after the redemocratization, which is marked by the Constitutions of 1988 and 1978 .

Due to the fact that education reforms are a complex and a multidimensional phenomenon, they will be analyzed solely from the structural aspect - restricting them to high school - and curricular - restricting them to Geography subject. The justifications, contradictions, as well as the ideological and politicaleconomic conflicts, involved in reforming process will be examined based on documents from Ministério da Educação (Brazil) and from Ministério de Educación y Ciencia (Spain). In addition to that, it will be researched the epistemological and theoretical-methodological divergence underlying the curricular modality of reforms.

Therefore, it is important to unveil especially the concept of knowledge society, which is one of the most appellant reasons for such reforms, beyond concepts of educational reforms, curriculum, knowledge, competencies, ideology and so on. It will be discussed also concepts and categories of Geography, especially in Brazilian documents pursuing unveil eventual contradictions and theoreticalmethodological conflicts existing in the field of Geography.

To achieve the purposes mentioned above, the research will be substantiated in the critical theory and the dialectical method. In order to establish it, subsidies on the critical theory of Frankfurt School thinkers will be pursued, especially Horkheimer and Habermas, and on the dialectic logic, particularly interpreted for Lefebvre. Based on prior conjecture of this method of approach, it is important to verify if the processes of reform have contributed or not to the individual's emancipation - teachers and students - for whom they are designated. That demands a discussion about the meaning of "emancipation". 


\section{Resumen}

Esta tesis pretende analizar comparativa y críticamente las leyes responsables por las reformas educativas hechas en Brasil y en España en el postredemocratización, período que tiene como marco las respectivas Constituciones, de 1988 y de 1978.

Como las reformas educativas son un fenómeno complejo y multidimensional serán analizadas solamente desde el punto de visto estructural ateniéndose a la enseñanza secundaria - y curricular - ateniéndose a la disciplina Geografía. Con base en los documentos del Ministério da Educação (Brasil) y del Ministerio de Educación y Ciencia (Espanha), procurársela investigar las justificativas, las contradicciones, así como los conflictos de intereses políticoeconómicos e ideológicos, involucrados en los procesos reformistas. Serán pesquisadas aún las divergencias epistemológicas y teórico-metodológicas subyacentes a modalidad curricular de las reformas.

Para tanto, es importante desvendar especialmente el concepto de sociedad del conocimiento, una de las justificativas más utilizadas para tales reformas, además de los conceptos de reforma educativa, currículo, conocimientos, competencias, ideología, entre otros. Serán discutidos también los conceptos y las categorías de la Geografía, especialmente en los documentos brasileños, procurando desvendar eventuales incoherencias y los conflictos teóricometodológicos existentes en ese campo disciplinar.

Para lograr los objetivos enunciados arriba, la pesquisa se fundamentará en el método de investigación crítico-dialéctico. Para su constitución serán buscados subsidios el la teoría crítica de los pensadores de la Escuela de Frankfurt, especialmente en Horkheimer y Habermas, y en la lógica dialéctica, particularmente como interpretada por Lefebvre. Con base en los presupuestos de ese método de investigación, es importante verificar si los procesos de reforma han contribuido o no para la emancipación de los sujetos - profesores y alumnos - a que se destinan. Eso exige una discusión del significado de "emancipación". 


\section{Lista de figuras}

Figura 1. Pirâmide informacional

Figura 2. Distribuição do rendimento dos alunos em matemática - PISA 2003

Figura 3. Capa da revista Educación y Gestión

Figura 4. Bacia do Pacífico: a) mapa "convencional", b) mapa do tempo-espaço

Figura 5. O encolhimento do mapa-múndi

\section{Lista de quadros}

Quadro 1. Interesses constitutivos do conhecimento e currículo

Quadro 2. Modos de operação da ideologia

Quadro 3. Matérias do núcleo comum da LDB 5692/71

Quadro 4. Sistema Educativo LGE

Quadro 5. Sistema Educativo LOGSE

Quadro 6. Espanha: sistema educativo obrigatório e pós-obrigatório

Quadro 7. Clase, género y etnia ante la educación

Quadro 8. Sistema Educativo LOE

Quadro 9. Sistemas educacionais: Brasil e Espanha

Quadro 10. Conceitos de Geografia: PCN + Ensino Médio

Quadro 11. Resumo dos conceitos-chave de Geografia: PCN + Ensino Médio

Quadro 12. Conceitos-chave de Geografia nos documentos do MEC

Quadro 13. Conceitos estruturantes e articulações: OCEM

Quadro 14. Competências-chave para a aprendizagem ao longo da vida 


\section{Lista de tabelas}

Tabela 1. Resultados da busca de termos na opção "a web" do Google Brasil (em 12 março 2008)

Tabela 2. Brasil: investimento público em educação básica (em bilhões de reais)

Tabela 3. Brasil: investimento público em educação (em \% do PIB)

Tabela 4. Brasil: investimento em educação básica por esfera de governo

Tabela 5. Brasil: evolução das matrículas no ensino médio

Tabela 6. Brasil: número de matrículas (em 29 março 2006)

Tabela 7. Brasil: taxa de desemprego por anos de estudo (2005)

Tabela 8. Vestibular FUVEST 2007: inscritos na prova

Tabela 9. Vestibular FUVEST 2007: convocados para matrícula

Tabela 10. Espanha: número de alunos matriculados em educação secundária e universitária (ano letivo 2007-2008)

Tabela 11. Distribuição dos alunos de educação primária e secundária por titularidade/financiamento (ano letivo 2004-2005)

Tabela 12. Gasto com educação por estudante em países selecionados, segundo o nível de ensino (2003, em US\$)

Tabela 13. Monográficos da Revista Iber dedicados à Geografia e outros temas da didática das Ciências Sociais 


\section{Lista de abreviaturas e siglas}

AGB - Associação dos Geógrafos Brasileiros

AGE - Asociación de Geógrafos Españoles

ANDE - Associação Nacional de Educação

APEOESP - Associação dos Professores do Ensino Oficial do Estado de São Paulo Arena - Aliança Renovadora Nacional

BA - Bahia

BID - Banco Interamericano de Desenvolvimento

BIRD - Banco Internacional de Reconstrução e Desenvolvimento (Banco Mundial)

BOE - Boletim Oficial del Estado

BUP - Bachillerato Unificado Polivalente

CE - Ceará

CEB - Câmara de Educação Básica

CEFET - Centro Federal de Educação Tecnológica

CENP - Coordenadoria de Estudos e Normas Pedagógicas

CEPAL - Comissão Econômica para a América Latina e o Caribe

CINTERFOR - Centro Interamericano para el Desarrollo del Conocimiento en la Formación Profesional

COU - Curso de Orientación Universitaria

DCN - Diretrizes Curriculares Nacionais

DCNEM - Diretrizes Curriculares Nacionais do Ensino Médio

DIEESE - Departamento Intersindical de Estatísticas e Estudos Socioeconômicos

EEPSG - Escola Estadual de Primeiro e Segundo Graus

EGB - Educación General Básica

EJA - Educação de Jovens e Adultos

EMBRAPA - Empresa Brasileira de Pesquisa Agropecuária

ENEM - Exame Nacional do Ensino Médio

ESO - Educación Secundaria Obligatoria

FFLCH - Faculdade de Filosofia, Letras e Ciências Humanas 
FMI - Fundo Monetário Internacional

FP - Formación Profesional

FUNDEB - Fundo de Desenvolvimento e Manutenção da Educação Básica e Valorização dos Profissionais da Educação

FUNDEF - Fundo de Manutenção e Desenvolvimento do Ensino Fundamental e de Valorização do Magistério

FUVEST - Fundação Universitária para o Vestibular

GPS - Global Positioning System (Sistema de Posicionamento Global)

IBGE - Instituto Brasileiro de Geografia e Estatística

INEP - Instituto Nacional de Estudos e Pesquisas Educacionais Anísio Teixeira

IPEA - Instituto de Pesquisa Econômica Aplicada

IRES - Investigación y Renovación Escolar

LDB - Lei de Diretrizes e Bases

LGE - Ley General de Educación

LOCE - Ley Orgánica de Calidad de la Educación

LODE - Ley Orgánica del Derecho a la Educación

LOE - Ley Orgánica de Educación

LOGSE - Ley de Ordenación General del Sistema Educativo

LOPEG - Ley Orgánica de la Participación, la Evaluación y el Gobierno de los

Centros

MDB - Movimento Democrático Brasileiro

MEC - Ministério da Educação

MEC - Ministerio de Educación y Ciencia

$M G$ - Minas Gerais

MRP - Movimento de Renovação Pedagógica

OCDE - Organização de Cooperação e Desenvolvimento Econômico

OCEM - Orientações Curriculares para o Ensino Médio

OIT - Organização Internacional do Trabalho

OSPB - Organização Social e Política Brasileira

PAU - Pruebas de Acceso a la Universidad

PCN - Parâmetros Curriculares Nacionais 
PCN+ - PCN + Ensino Médio: Orientações Educacionais Complementares aos Parâmetros Curriculares Nacionais

PCNEM - Parâmetros Curriculares Nacionais do Ensino Médio

PDS - Partido Democrático Social

PDT - Partido Democrático Trabalhista

PE - Pernambuco

PFL - Partido da Frente Liberal

PIB - Produto Interno Bruto

PISA - Programme for International Student Assesment (Programa Internacional de Avaliação de Alunos)

PL - Projeto de Lei

PLC - Projeto de Lei da Câmara

PMDB - Partido do Movimento Democrático Brasileiro

PNLD - Programa Nacional do Livro Didático

PNUD - Programa das Nações Unidas para o Desenvolvimento

PP - Partido Popular (Espanha)

P-P - Primária-Profissional

PPC - Paridade de Poder de Compra (dólar)

PSD - Partido Social Democrático

PSDB - Partido da Social Democracia Brasileira

PSOE - Partido Socialista Obrero Español

PST - Partido Social Trabalhista

PT - Partido dos Trabalhadores

PTB - Partido Trabalhista Brasileiro

PUC - Pontifícia Universidade Católica

QI - Quociente de Inteligência

RJ - Rio de Janeiro

SC - Santa Catarina

S-S - Secundária-Superior

UCD - Unión de Centro Democrático

UDN - União Democrática Nacional 
UERJ - Universidade do Estado do Rio de Janeiro

UNESCO - Organização das Nações Unidas para a Educação, a Ciência e a Cultura

UNESP - Universidade Estadual Paulista

UNICAMP - Universidade Estadual de Campinas

UNICEF - Fundo das Nações Unidas para a Infância

USAID - United States Agency for International Development (Agência dos Estados

Unidos para o Desenvolvimento Internacional)

USP - Universidade de São Paulo

\section{Sumário}

Introdução

Parte I: A fundamentação teórico-Metodológica

1. Reforma educacional e currículo

Reformareformareforma...

Currere $\rightarrow$ curriculum $\rightarrow$ currículo

2. O método: a dialética e a teoria crítica

Introdução ao método

Método de abordagem

Os métodos científicos

O método dialético

A teoria crítica

Abordagem crítica em Educação: algumas possibilidades

Tópicos sobre ideologia e cultura

Método de procedimento

Corpus dos documentos analisados na pesquisa

3. A sociedade do conhecimento e as reformas educacionais

Conceitos informacionais

O advento da sociedade do conhecimento

Competências 
As reformas educacionais, a sociedade do conhecimento e o currículo

Parte II: A reforma estrutural no Brasil e na Espanha: ensino médio

1. O sistema educacional brasileiro e as mudanças no ensino médio

Antecedentes: a LDB 5692/71

A LDB 9394/96

A tramitação da lei

Uma lei minimalista

Reforma do ensino médio: DCNEM, PCNEM...

Adaptação à sociedade do conhecimento

Propedêutico, técnico ou preparação básica para o trabalho

2. O sistema educativo espanhol e as mudanças na educação secundária 138

Antecedentes: Ley General de Educación (LGE)

Ley Orgánica Reguladora del Derecho a la Educación (LODE)

Ley de Ordenación General del Sistema Educativo (LOGSE)

Ley Orgánica de Calidad de la Educación (LOCE)

Ley Orgánica de Educación (LOE)

3. Comparação entre o Brasil e a Espanha

Parte III: A reforma curricular no Brasil e na Espanha: Geografia

\section{A Geografia no ensino médio brasileiro}

Antecedentes: A Geografia no currículo do segundo grau

O currículo do ensino médio

Conhecimento interdisciplinar ou disciplinar? E as competências?

E o papel dos professores?

A Geografia nas propostas curriculares para o ensino médio

Os PCNEM e o espaço geográfico: conceito estruturante

As OCEM e o espaço: conceito ou categoria?

2. A Geografia no ensino secundário espanhol

Antecedentes: a Geografia na $L G E$

A LOGSE e as enseñanzas mínimas 
Educación Secundaria Obligatoria

Bachillerato

As enseñanzas mínimas sob o governo dos Populares

Educación Secundaria Obligatoria

Bachillerato

A LOE e as enseñanzas mínimas

Educación Secundaria Obligatoria

Bachillerato

3. Comparação entre o Brasil e a Espanha

(In)conclusões

Referências bibliográficas 


\section{INTRODUÇão}

Vou começar falando um pouco de mim, não por egocentrismo, mas porque a definição de um objeto de pesquisa, e especialmente o desenvolvimento de uma tese na tentativa de esclarecê-lo, é resultado de um longo percurso. Sintetizam, muitas vezes, experiências, dúvidas e reflexões de toda uma vida de estudos e de trabalho. Além disso, o método que embasa esta pesquisa não aceita a separação entre sujeito e objeto, entre teoria e prática. Estou envolvido com o objeto a ser estudado, e minha experiência profissional - meu contexto - será levada em conta em muitas passagens deste texto. Não dá para entender o texto sem o contexto.

Estudei o primeiro grau em escolas públicas estaduais de Barueri e Carapicuíba, na Grande São Paulo. No segundo grau, fiz o curso técnico de agrimensura no Instituto Tecnológico de Osasco, escola técnica municipal, que apesar de barata era paga. Depois desisti de ser técnico e prestei vestibular para o curso de Geografia da Universidade de São Paulo (USP). Antes mesmo de me formar, tornei-me professor.

Ao longo de quinze anos lecionei em escolas públicas e privadas de ensino médio e em cursos pré-vestibular da Grande São Paulo e do interior. Comecei, em 1985, na Escola Estadual de Primeiro e Segundo Graus (EEPSG) Dom Duarte Leopoldo e Silva, no bairro do Socorro, zona sul paulistana. Em minha estréia como professor, estava tão-somente no $2^{\circ}$ semestre do $1^{\circ}$ ano do curso de Geografia. Evidentemente pouco sabia dos conteúdos dessa disciplina, muito menos de didática, mas tinha entusiasmo e vontade de aprender a aprender, aprender a ensinar e ensinar a aprender. No segundo ano da faculdade, em 1986, lecionei no EEPSG Antonio Raposo Tavares, em Osasco. Naquele mesmo ano comecei a fazer plantão de dúvidas no Curso Anglo da mesma cidade e no ano seguinte tornei-me professor de cursinho pré-vestibular. Trabalhei no Anglo, nas unidades de Guarulhos, Sorocaba, Osasco e São Paulo. 
Em 1989, no último ano da faculdade, comecei a lecionar no Curso Stockler, no Brooklin, zona sul de São Paulo, onde permaneci por dez anos e aprendi muito. Além de escrever as apostilas de Geografia - primeiro ensaio para os livros que depois viriam -, como havia poucos alunos por sala, conseguia acompanhá-los de perto e detectar as principais dificuldades que traziam do ensino médio.

Muitas das experiências que tive, das soluções empíricas e intuitivas que encontrei, especialmente no Dom Duarte, no Raposo Tavares e no Stockler, só fui compreender muito tempo depois. Só mais tarde percebi o quanto elas foram importantes para produzir livros didáticos e chegar às reflexões que ora desenvolvo nesta pesquisa.

Em 1998, publiquei meu primeiro livro pela Editora Scipione - Geografia geral e do Brasil: espaço geográfico e globalização -, voltado para o ensino médio. Desde essa época, escrevi diversos livros didáticos de Geografia para o ensino fundamental e médio. No processo de divulgação desses livros, venho tendo a oportunidade de fazer palestras em diversos lugares do Brasil e conhecer muitos professores, com os quais tenho estabelecido uma enriquecedora troca de experiências. Esse contato intersubjetivo, somado à observação das realidades diversas do país, procurei levar em consideração em determinadas passagens deste trabalho.

Deixei o magistério no final de 1999, quando lecionava exclusivamente no Curso e Colégio Stockler. Antes disso, porém, em 1998, além de no curso prévestibular, passei a dar aulas para a primeira turma do colégio, que acabara de abrir, com a qual tive a oportunidade de utilizar meu livro de ensino médio recémpublicado. Naquele momento as atividades editoriais tornaram-se incompatíveis com o trabalho docente e tive de concentrar-me nos livros, para os quais direcionei o trabalho de educador.

Essa experiência acumulada levou-me a refletir sobre a educação em geral e, em especial, sobre o ensino de Geografia no nível médio. Isso, conseqüentemente, levou-me a questionar alguns de seus fundamentos, de seus 
objetivos, e a procurar compreender melhor o sistema educativo brasileiro como um todo.

Aliado a isso, a produção de uma dissertação de mestrado, defendida em 2001, permitiu-me aprofundar a reflexão sobre as características do atual momento do capitalismo informacional. Essa pesquisa, desenvolvida no Departamento de Geografia da FFLCH-USP sob orientação do professor André Martin, transformouse, dois anos depois, no livro Globalização e espaço geográfico, publicado pela Editora Contexto.

A revolução técnico-científica, o processo de globalização e o advento da chamada sociedade do conhecimento têm criado novas demandas para os trabalhadores-cidadãos (duas dimensões da pessoa que são inseparáveis) e isso inevitavelmente tem implicações na Educação.

Desde há muito me parece que a escola não vem conseguindo enfrentar as novas e ampliadas demandas do mundo contemporâneo, marcado por rápidas transformações econômicas, tecnológicas, políticas e culturais. Tenho pensado sobre as conseqüências dessas transformações no sistema educacional, em especial no ensino médio. A educação secundária, a que mais sofre com essas mudanças, vem enfrentando alguns dilemas no mundo todo, e não é diferente no Brasil. Assim, colocam-se algumas questões: a educação média deve propiciar uma formação propedêutica, técnica ou uma formação básica para o trabalho? E, nesse contexto, como fica a formação da pessoa? Deve ser calcada na disciplinaridade ou na interdisciplinaridade? E qual é o lugar da Geografia? Seus conceitos permitem compreender o mundo atual?

Há ainda muitas outras indagações: quais são as mudanças ensejadas na educação secundária pela revolução informacional e pela emergência da sociedade do conhecimento? Como os governos, por meio de seus Ministérios da Educação, têm buscado dar respostas a elas?

Para elucidar algumas dessas indagações, decidi estudar comparativamente as reformas educacionais no Brasil e na Espanha. Para embasar a análise dos documentos dos governos dos dois países, busquei construir uma fundamentação teórico-metodológica ancorada nos pressupostos da teoria crítica e 
da lógica dialética. Com isso, espero fazer uma análise do momento presente orientada por um comportamento crítico, na busca de desvendar as contradições existentes, os conflitos de interesse entre setores da sociedade e também identificar o potencial emancipatório do processo ou os bloqueios existentes.

Antes de debruçar-me sobre a pesquisa, pensava que a escola deveria dar respostas diretas às demandas do sistema produtivo, do mercado de trabalho. Talvez por minha longa experiência em cursos pré-vestibular, tinha, devo admitir, uma visão um tanto instrumental da educação escolar. Entretanto, à medida que pesquisava e refletia, dei-me conta de que o papel da educação escolar deveria ir muito além de simplesmente dar respostas às demandas da economia. Tinha como hipótese a priori que a educação não estava se adaptando às mudanças impostas pela atual revolução técnico-científica. E, à medida que lia os documentos oficiais das reformas, confirmava essa minha impressão inicial. De fato, como veremos ao longo do trabalho, entre as principais justificativas para as constantes reformas educacionais predomina a necessidade de adaptação ao atual momento do capitalismo, marcado pela revolução informacional, dando origem à chamada sociedade do conhecimento. Isso está muito presente nos documentos brasileiros e espanhóis. Assim, ao que parece, as possibilidades de emancipação são muito limitadas porque a pessoa foi subsumida pelo trabalhador na formação escolar, quando deveria ser o contrário.

Parece-me oportuno o estudo dessas questões no momento em que a Lei de Diretrizes e Bases da Educação Nacional (LDB 9394/96) já completou mais de dez anos e os Parâmetros Curriculares Nacionais do Ensino Médio (PCNEM), lançados em 1999, estão caducando sem se tornarem efetivos. "Tal proposta não se concretizou", na opinião do então Secretário de Educação Básica, Francisco das Chagas Fernandes ${ }^{1}$ (BRASIL, 2004a). Seu formato inicial está sendo questionado e novas propostas foram lançadas por meio do documento PCN + Ensino Médio: Orientações Educacionais Complementares aos Parâmetros Curriculares Nacionais, de 2002, e das Orientações Curriculares para o Ensino Médio (OCEM). Uma versão

\footnotetext{
Francisco das Chagas Fernandes era o Secretário da Educação Básica na época do lançamento da versão preliminar das Orientações Curriculares do Ensino Médio; atualmente o mesmo cargo é ocupado por Maria do Pilar Lacerda Almeida e Silva. (Secretaria de Educação Básica. MEC. Disponível em: $<$ http://portal.mec.gov.br>. Acesso em: 20 out. 2008).
} 
preliminar desse documento foi publicada em 2004 e suscitou a realização de cinco Seminários Regionais e um Seminário Nacional sobre o currículo de ensino médio. Com base nesse acúmulo de reflexões, foi elaborada a versão final da proposta, publicada em 2006.

Em outros países, os governos também têm promovido reformas educacionais. Na Espanha, em 2004, o Ministério de Educación y Ciencia lançou o documento "Una educación de calidad para todos y entre todos: propuestas para el debate", base para discussão e propostas visando à consecução de mais uma reforma educativa. No final de 2005, foi aprovada no parlamento a Ley Orgânica de Educación (LOE), sancionada pelo rei Juan Carlos no início de 2006. Essa é a quinta reforma educativa desde a promulgação da Constituição de 1978, marco do processo de redemocratização do país.

A escolha da Espanha para o estudo comparado com o Brasil tem várias justificativas. Em primeiro lugar, deve-se à influência das propostas educacionais daquele país não apenas no sistema educativo brasileiro, mas no de outros países da América Latina. Além disso, trata-se de um país que pertencia à periferia da União Européia, à qual se juntou apenas em 1986, desde quando vem se empenhando para se integrar competitivamente na economia comunitária e global; dentro desse contexto, a Educação assumiu um papel fundamental. Situação análoga ocorre no Brasil, país que ainda pertence à periferia do capitalismo e tem feito grandes esforços para se integrar à economia global. Porém, ao que parece, a sociedade brasileira ainda não se deu conta plenamente da importância crucial da Educação nesse processo.

Embora o Brasil tenha uma população 4,3 vezes maior que a da Espanha ${ }^{2}$, ambos os países têm economias de tamanho equivalente, o que significa que o país europeu é mais rico em termos per capita ${ }^{3}$ e apresenta indicadores de

\footnotetext{
De acordo com o relatório World Development Report 2008 (THE WORLD BANK, 2007), em 2006 a população total do Brasil era de 189 milhões de habitantes e a da Espanha, de 44 milhões.

De acordo com o mesmo relatório do Banco Mundial, em 2006 o PNB do Brasil era de US\$ 893 bilhões e o da Espanha, de US\$ 1.201 bilhões. Quando se considera o PNB em dólar PPC, que leva em conta a paridade de poder de compra das respectivas moedas, o PNB brasileiro passa a US\$ (PPC) 1661 bilhões e o da Espanha a US\$ (PPC) 1221 bilhões. O PNB per capita do Brasil era de US\$ 4730 e US\$ (PPC) 8800, o da Espanha era de US\$27570 e US\$ (PPC) 28030.
} 
desenvolvimento humano mais elevados ${ }^{4}$. Os indicadores educacionais da Espanha também são mais elevados que os do Brasil. Durante a análise das reformas educacionais implementadas nos dois países, sobretudo no capítulo 3 da parte II, serão elencadas mais informações socioeconômicas, especialmente educacionais, que permitirão melhor comparação entre eles.

Os dois países viveram um longo período de regimes de exceção - a ditadura de Francisco Franco na Espanha (1939-1975) e a ditadura militar brasileira (1964-1985). A promulgação de uma nova Constituição, tanto lá, em 1978, como cá, em 1988, foi o divisor de águas para a abertura política e a consolidação da democracia. Por isso vou concentrar a análise nas leis educacionais do período pósabertura política de cada um desses países.

Há também uma questão afetivo-subjetiva na escolha da Espanha. Nas quatro vezes que visitei o país, senti-me "em casa", especialmente na última, em que permaneci cinco semanas para conhecer melhor seu sistema educativo e os documentos das reformas. Estive em contato com o professor Horacio Capel da Universidade de Barcelona e conheci diversas pessoas em universidades, no Ministério de Educación y Ciencia, em bibliotecas etc. Todos foram muito solícitos em me auxiliar: cedendo ou indicando livros e documentos, respondendo a indagações e esclarecendo dúvidas.

Por fim, acredito que esta pesquisa pode contribuir para compreender comparativamente as reformas educacionais no Brasil e na Espanha, especialmente em suas modalidades estrutural e curricular: suas injunções políticas, suas contradições, os conflitos de interesses, a (in)adequação às demandas do mundo atual, sua contribuição ou não para a emancipação dos sujeitos envolvidos na relação ensino-aprendizagem.

Vejamos a seguir um resumo dos objetivos - geral e específicos - desta pesquisa. Ao longo dos três capítulos da parte I, que tratam da fundamentação teórico-metodológica, esses objetivos serão contextualizados e mais bem explicitados.

De acordo com o Relatório de Desenvolvimento Humano 2007/2008 (PNUD, 2007)), em 2005 a Espanha apresentava um Índice de Desenvolvimento Humano (IDH) de 0,949, o $13^{\circ}$ do mundo. Portanto, é um país de alto IDH. O Brasil no mesmo relatório tinha um IDH de $0,800,70^{\circ}$ colocado no mundo, último entre os países de alto IDH. 


\section{Objetivos da pesquisa}

\section{Geral}

Analisar, da perspectiva crítico-dialética e de forma comparada, com base nos documentos do Ministério da Educação (Brasil) e do Ministério de Educación y Ciencia (Espanha), as reformas educacionais implementadas após a abertura política nos dois países. Discutir tais reformas em sua modalidade estrutural centrada no ensino médio - e curricular - focada na Geografia. Buscar as justificativas, as contradições, as divergências teórico-metodológicas e os conflitos de interesse - político-econômicos e ideológicos - envolvidos. Verificar se contribuem ou não para a emancipação dos sujeitos aos quais se destinam.

\section{EsPecíficos}

1. Analisar comparativa e criticamente as leis responsáveis pelas reformas do ponto de vista estrutural - atendo-se ao ensino médio - com base nos documentos do Ministério da Educação e do Ministério de Educación y Ciencia, buscando suas justificativas, suas contradições e os conflitos de interesses político-econômicos e ideológicos envolvidos. Desvendar especialmente o conceito de sociedade do conhecimento, uma das justificativas mais recorrentes para tais reformas.

2. Analisar comparativa e criticamente os documentos dos respectivos Ministérios da Educação responsáveis pelas reformas do ponto de vista curricular - atendo-se à Geografia -, buscando suas justificativas, suas contradições e as divergências epistemológicas e teórico-metodológicas 
envolvidas. Analisar conceitos e categorias da Geografia, especialmente nos documentos brasileiros, procurando desvendar eventuais incoerências.

3. Elucidar o método de abordagem crítico-dialético que embasa esta pesquisa, buscando subsídios na teoria crítica dos pensadores da Escola de Frankfurt e na lógica dialética, especialmente como expressada por Henri Lefebvre. Verificar se os processos de reforma contribuem ou não para a emancipação dos professores e alunos aos quais se destinam.

4. Delimitar conceitos e categorias de análise utilizados nesta pesquisa, tais como reforma educacional, currículo, sociedade do conhecimento, revolução informacional, conhecimentos, competências e ideologia. Discutir a coerência desses conceitos e categorias, procurando desvendar o que têm de heurístico ${ }^{5}$ e de ideológico.

5 "Heurístico (do grego heuriskein: encontrar). Que se refere à descoberta e serve de idéia diretriz numa pesquisa, de enunciação das condições da descoberta científica." (JAPIASSU; MARCONDES, 2006, p. 131). Abbagnano (1998, p. 605) define heurística simplesmente como "busca ou arte da busca". Para "encontrar", para "descobrir" é preciso "buscar", mas com método e conceitos coerentes. 


\section{Parte I}

A FUndamentação teórico-MEtodológica 


\section{Reforma eduCACIONAL E CURRículo}

\section{Reformareformareforma...}

Com este subtítulo inusitado, gostaria de indicar que as reformas educacionais $^{6}$ são um processo sem fim, permanentemente inacabado. Desde que foram organizados, formados, os modernos sistemas educativos passam periodicamente por reformas, ganhando nova organização, nova forma. As grandes rupturas são raras - aliás, é por isso que se chama "reforma" educacional. Há uma certa continuidade no processo reformista: a nova reforma vai se imbricando na anterior, criando, muitas vezes, como no caso espanhol, um emaranhado de leis superpostas. Mas, como definir "reforma educacional" e por que recentemente há uma profusão delas em diversos países?

Considerando que, como afirma Gimeno Sacristán (2006), a Educação é um subsistema da cultura, podemos considerar uma reforma educacional um processo ou movimento social. Johnson (1997, p. 155, grifo do autor), em seu Dicionário de Sociologia, considera que movimento social "é um esforço coletivo contínuo e organizado que se concentra em algum aspecto de mudança social. Um movimento de reforma tenta melhorar condições em um sistema social, mas sem modificar seu caráter fundamental". Fairchild (1997, p. 250), em seu Diccionario de Sociología, define reforma como "mejora en un rasgo social particular, más bien en el aspecto funcional que en la estructura". Na mesma linha, Gimeno Sacristán (2006, p. 31) acredita que "reforma es aquello que se propone, proyecta o ejecuta como innovación o mejora en algo, que lo transforma (cambia de forma)". Lerena (1999), mais cético, para enfatizar que as reformas educativas estão voltadas mais para

\footnotetext{
Utilizarei indistintamente os termos "educacional" e "educativo" para me referir ao sistema de ensino e às reformas na área da educação tanto da Espanha como do Brasil, porque, tanto em espanhol como em português, essas palavras são sinônimas, embora, em espanhol, seja mais comum se falar em "reforma educativa" e, em português, em "reforma educacional". "Educacional" e "educativo", no dicionário da Real Academia Española (2007), aparecem como "perteneciente o relativo a la educación” e, no Houaiss (2008), aparecem como "relativo à educação". "Educativo" também aparece com a acepção "que educa o sirve para educar" naquele dicionário, e "que contribui para a educação", neste.
} 
conservação do que para mudança de uma estrutura social de classes, fala em "reforma reformista".

O termo "reforma" aplicado à Educação se impõe na década de 1970 no contexto dos debates internacionais sobre o tema. O informe da UNESCO Aprender a ser - elaborado em 1973 pela Comissão Faure afirmava:

Una de las características de los sistemas educativos contemporáneos es que están sometidos, y se someten ellos mismos, a un proceso continuo de adaptaciones, de mejoras, de modernizaciones, en una palabra, de reformas parciales que, sin modificar a fondo las instituciones o las prácticas existentes, preceden por lo general, acompañan a menudo y suplen a veces las transformaciones más profundas de carácter innovador. (FAURE, 1973, p. 261 apud GIMENO SACRISTÁN, 2006, p. 37).

Como se percebe pelas transcrições acima, o conceito de reforma apresenta uma conotação positiva e está sempre associado à mudança de um sistema visando a uma melhora. Mesmo nos dicionários comuns o vocábulo apresenta entre outras acepções: "2. mudança introduzida em algo para fins de aprimoramento e obtenção de melhores resultados; nova organização, nova forma; renovação; 3. melhoramento introduzido em âmbito moral ou social." (HOUAISS, 2008) e "3. nova forma; 4. mudança para melhor; melhoramento" (MICHAELIS, 1998).

Porém, melhora exatamente do que se está falando, já que o sistema educativo é complexo e multidimensional? Cesar Coll, um dos artífices da reforma espanhola de 1990, chama a atenção para o fato de que uma verdadeira reforma educativa não deve limitar-se a um conjunto de mudanças estruturais e de ordenação do sistema educacional, mas precisa estar voltada, antes de tudo, para a melhoria da qualidade de ensino. Para ele, "el único cambio educativo de interés es el que tiene como objetivo mejorar la calidad de la enseñanza". (COLL, 1992, p. 34). De fato, as mudanças estruturais (incluindo as curriculares) e organizativas do sistema educativo só fazem sentido se forem meios para atingir um fim maior: a melhoria da qualidade da relação ensino/aprendizagem, possibilitando condições para que os professores ensinem melhor e, especialmente, para que os alunos aprendam melhor. Entretanto, muitos desconfiam dos conceitos de "melhora" e "qualidade", de que esteja havendo sua instrumentalização. Para Romero Morante e 
Luis Gómez (2008, p. 2) "la insistencia en los 'estándares' y en los 'resultados' de los alumnos propende a redefinir las nociones de 'mejora' y 'calidad' desde una óptica productivista, acentuada por el creciente impacto normativo de las evaluaciones internacionales".

Disto emana uma questão fundamental: quem introduz essa mudança supostamente para melhor no campo da Educação? A explicação de Viñao (2006, p. 43) é esclarecedora: "Las reformas educativas son intentos de transformación o cambio educativo generados e impulsionados desde los poderes públicos ya se trate de los gobiernos centrales o estatales, autónomos, regionales o municipales.". Nesse sentido, distingue reforma de inovação ou outros processos de renovação pedagógica. Aquela é gestada no aparelho de Estado, em geral na esfera central, é fruto de uma lei; estas, embora possam contar com o apoio do Estado, são promovidas por grupos de renovação pedagógica compostos por professores, como os vários que existem na Espanha ${ }^{7}$.

Essa distinção é importante porque permite esclarecer que este trabalho vai se concentrar apenas na análise das reformas educacionais, ou seja, das leis orgânicas (e legislações complementares delas derivadas) que induzem a mudanças legais no sistema educativo. Permite também levantar uma questão fundamental: se a Educação é um subsistema da cultura e as sociedades são heterogêneas, quem garante que a reforma é uma mudança para melhor? Essa dúvida justifica o termo "supostamente" algumas linhas acima. De fato, embora a melhora seja a intenção dos sujeitos que impulsionam uma reforma, como as sociedades são heterogêneas e contraditórias, o que é considerado melhoria para determinados setores sociais pode não ser para outros. Isso sem dúvida ocorre no caso brasileiro e mais explicitamente no espanhol. Como veremos no capítulo 2 da parte II, a Espanha é marcada por um nítido bipartidarismo no plano político, com grupos de apoio muito delimitados e com algumas posições político-ideológicas frontalmente antagônicas, o que torna difícil um acordo sobre a "melhora". O que um grupo considera melhora,

\footnotetext{
Na Espanha são conhecidos como Movimientos de Renovación Pedagógica (MRP), por exemplo: Investigación y Renovación Escolar (Ires), de Andaluzia; Cronos, de Salamanca; Ínsula Barataria, de Aragão; o Asklepios, de Cantábria; Gea-Clío, de Valência; Aula Sete, da Galícia; e Pagadi, de Navarra. Todos esses grupos fazem parte da Federación Icaria. (FedIcaria. Disponível em: <www.fedicaria.org/miembros.html>. Acesso em: 10 set. 2008),
} 
avanço, o outro considera piora, retrocesso, e vice-versa; um terceiro grupo, "alternativo", pode avaliar que as mudanças foram insuficientes.

Para Álvaro Marchesi, professor de Psicologia Evolutiva da Universidade Complutense de Madrid e um dos responsáveis pelo desenho e aplicação da Ley de Ordenación General del Sistema Educativo (LOGSE) de 1990, houve melhora:

La mejora de la calidad de la enseñanza fue uno de los grande objetivos de la LOGSE. Además de ser la perspectiva general de la mayoría de las propuestas que en ellas se hacían, recibió un tratamiento específico en su título quinto. En él se señalaron un conjunto de factores que favorecen la calidad y la mejora de la enseñanza: la cualificación y formación del profesorado, la programación docente [...]. (MARCHESI, 2005, p. 17).

Para Pascual Tamburri, professor de História do Instituto San Adrián (Navarra), articulista de Elsemanaldigital.com e um dos críticos mais ferozes da LOGSE, houve piora:

La sociedad española ha experimentado en las últimas dos décadas un proceso de transformación en gran medida enriquecedor y positivo, pero en algunos aspectos esenciales indudablemente negativo. Algunos principios que se han considerado irrenunciables desde los albores de nuestra civilización han sido sustituidos por valores alternativos cuya imposición definirá en breve una cultura diferente. En el terreno educativo, ese cambio se simboliza, sí, en la aplicación de la LOGSE socialista [...]. (TAMBURRI, 2007, p. 17).

No caso da sociedade brasileira, embora não tão polarizada, há também divergências sobre o que pode ser considerado "melhora" na Educação, como veremos no capítulo 1 da parte II.

Reforma educacional é um processo complexo de mudanças de maior ou menor espectro que de tempos em tempos ocorre no sistema educativo de todos os países. Entretanto, desde os anos 1970, essas mudanças se tornaram mais freqüentes em diversos países, especialmente a partir dos anos 1990.

$\mathrm{Na}$ Espanha, considerando apenas a lei principal que regulamenta o sistema educativo, da qual se desdobram leis complementares e decretos, desde a Ley General de Educación (LGE), de 1970, que modificou um sistema que vinha sendo regulado pela mesma lei desde 1857 (Ley Moyano), foram elaboradas seis reformas! A última, que está atualmente sendo posta em prática, é a Ley Orgánica 
de Educación (LOE), de 2006, que substituiu todas as anteriores, exceto a Ley Orgánica del Derecho a la Educación (LODE), de 1985.

No Brasil os legisladores foram mais comedidos: tivemos a Lei de Diretrizes e Bases para o Ensino de $1^{\circ}$ e $2^{\circ}$ graus $n^{\circ} 5692$, de 1971, e mais recentemente a Lei de Diretrizes e Bases da Educação Nacional n. 9394, de 1996, que substituiu aquela. Entretanto, por ser um texto legal enxuto, delegou para leis complementares a responsabilidade da reforma, pelo menos em sua modalidade curricular. É nesse contexto que entram as Diretrizes Curriculares Nacionais (DCN) e os Parâmetros Curriculares Nacionais (PCN). Os PCN vêm sendo elaborados e reelaborados desde a segunda metade da década de 1990 e pretendem ser uma referência curricular em nível nacional.

Mas não é só o Brasil e a Espanha que têm feito reformas educativas recentemente; novas leis educacionais têm sido elaboradas em diversos outros países, como Chile (1990, 2007), México (1993), Argentina (1993, 2006), Colômbia (1994), Bolívia $(1994,2007)$ e Estados Unidos (2004). Por que essa coincidência?

As reformas, as leis orgânicas de educação, são extremamente complexas, têm um caráter multidimensional, porque procuram ordenar e regular diversos aspectos do sistema educativo do país onde são elaboradas, discutidas, votadas, aprovadas e aplicadas.

Gimeno Sacristán (2006) não se arrisca a fazer uma classificação das reformas educacionais. Afirma que são tantos os aspectos envolvidos na Educação - objetivos, práticas, agentes implicados etc. - que se torna difícil caracterizar nitidamente as reformas educativas e fazer uma tipologia clara delas.

Viñao (2006), entretanto, elabora uma tipologia das reformas educacionais classificando-as em quatro modalidades. Dependendo da ênfase dada a um ou outro aspecto do sistema escolar, elas podem ser estruturais, curriculares, organizativas e político-administrativas. Com base nesse autor, as reformas são:

- estruturais: quando modificam os níveis, etapas ou ciclos do sistema e, com isso ou não, os requisitos para ingressar neles, os títulos ou certificados que são expedidos em sua conclusão e seu valor ou efeitos acadêmicos; 
- curriculares: quando buscam estabelecer, por via legal ou administrativa, determinada concepção do currículo em relação com os conteúdos que se ensina, com a metodologia utilizada para ensinar e com a avaliação;

- organizativas: quando afetam a organização e a estrutura das escolas, desde seus órgãos de direção e gestão até sua organização e estrutura acadêmica;

- político-administrativas: quando modificam o modo de dirigir, administrar e gerir os sistemas educativos no que se refere à divisão de competências entre os diferentes poderes públicos e também entre os órgãos de gestão e inspeção desses poderes.

Coll (1992), por sua vez, nos chama a atenção para o fato de que há reformas de caráter global e parcial. Uma reforma global, como o próprio nome sugere, preocupa-se com a transformação, em maior ou menor grau, de todos os aspectos do sistema educativo. Já uma reforma parcial preocupa-se com a mudança de algum aspecto particular do sistema, de maneira isolada, como a administração, o currículo, a formação docente etc., ou com um nível específico: educação infantil, primária, secundária ou superior.

Na Espanha, a Ley General de Educación (LGE), profunda reforma realizada em 1970, que alterou o sistema educativo herdado da Ley Moyano de 1857, abarcou as quatro modalidades apontadas por Antonio Viñao. Trata-se, portanto, de uma reforma global, como nos sugere Cesar Coll. A Ley Orgánica del Derecho a la Educación (LODE), de 1985, foi uma reforma eminentemente organizativa, mas, por entrar na questão da repartição de competências entre o Estado central e as Comunidades Autônomas, pode ser também qualificada de político-administrativa.

A Ley de Ordenación General del Sistema Educativo (LOGSE), de 1990, segundo Viñao (2006), foi sobretudo uma reforma estrutural e curricular e, pelo mesmo motivo da $L O D E$, também teve um caráter político-administrativo. Coll (1992), entretanto, considera que essa lei subsidiou uma reforma global, que 
abarcou todos os níveis não universitários do sistema educativo espanhol. E ele a conhece bem, afinal foi o principal responsável por sua elaboração.

A lei atualmente em vigor, a Ley Orgânica de Educación (LOE), não imprimiu grandes mudanças à ordenação da Educação espanhola. Herdou da $L O D E$, única lei anterior não anulada por ela, o caráter organizativo do sistema educacional, e da LOGSE, apesar de anulada, a estruturação dos níveis de ensino, e de ambas a organização político-administrativa. Na prática, como veremos, a $L O E$ promoveu mais mudanças no plano curricular. As outras reformas feitas na Espanha nos anos 1990 tiveram caráter parcial.

No Brasil, as duas Leis de Diretrizes e Bases (LDB), a n. 5692, de 1971, e n. 9394, de 1996, são exemplos de reformas globais, que abarcam as quatro modalidades descritas por Viñao (2006).

Aproveito o ensejo para esclarecer que, no desenvolvimento deste trabalho, focalizarei a análise nas modalidades estrutural e curricular das reformas implementadas no Brasil e na Espanha, buscando compreender o papel das leis especialmente das mencionadas acima. Para compreender as reformas atuais, é necessário buscar sua gênese nas anteriores, por isso o recorte temporal desta pesquisa será a abertura política que ocorreu na Espanha a partir da promulgação da Constituição de 1978 e no Brasil a partir da Constitução de 1988. No que tange à estrutura do sistema de ensino, concentrar-me-ei no estudo do nível médio ou secundário, e com relação ao currículo farei uma análise particular da disciplina Geografia.

Há diversos fatores que vêm impulsionando essas reformas: alguns particulares de cada país, como a alternância de partidos políticos no poder e a polarização político-ideológica, visível no caso espanhol; outros mais gerais, que aparecem como justificativa nos preâmbulos das leis de quase todos países. Toda lei reformista, de um modo ou de outro, busca adaptar o sistema educativo do país onde é elaborada às mudanças - políticas, socioeconômicas e tecnológicas - que estão ocorrendo no momento presente do capitalismo, com destaque para as novas necessidades do mercado de trabalho. Na Espanha, como consta no preâmbulo da Ley Orgánica de Educación (LOE), busca-se preparar o país para a competição 
globalizada, para a chamada "sociedade do conhecimento"8 (ESPAÑA, 2006a, p. 31). No Brasil, o documento Parâmetros Curriculares Nacionais do Ensino Médio (PCNEM) - um desdobramento da LDB 9394/96 -, ao discutir o papel para "O novo Ensino Médio", propugna a necessidade de levar em conta as mudanças provocadas pela "revolução do conhecimento", que vem "alterando o modo de organização do trabalho e as relações sociais" (BRASIL, 2002a, p. 16).

Autores dos mais variados matizes teóricos e político-ideológicos muitas vezes convergem sobre as justificativas das reformas, o que muda são os caminhos apontados para a adaptação a elas. Francisco López Rupérez, catedrático de Instituto e ex-Secretario Geral de Educação do governo José Maria Aznar, situado no campo político-ideológico conservador, afirma que:

\begin{abstract}
Los gobiernos de los países avanzados están cada vez más interesados en los resultados de sus respectivos sistemas educativos y hacen esfuerzos permanentes por mejorarlos. Existen razones de muy distinta índole que explican ese reforzado interés por los resultados. En primer lugar, los progresivos avances en el proceso de globalización se ven acompañados por una evolución de la economía y de la sociedad hacia estadios en los cuales el conocimiento desempeña un papel fundamental. (LÓPEZ RUPÉREZ, 2006, p. 21, grifo do autor).
\end{abstract}

Para Antonio Viñao, professor da Universidade de Murcia e teórico situado no campo progressista, as justificativas mais comuns, presentes nos preâmbulos das leis que as regulamentam, são:

[...] las referencias a una supuesta crisis de la educación, a la baja calidad de la enseñanza, al elevado fracaso escolar, a la necesaria adaptación a los cambios sociales y tecnológicos sobrevenidos en los últimos años, a las exigencias y a los nuevos retos de la globalización económica, de al llamada sociedad del conocimiento y de la información y del proceso de convergencia europea, así como a la necesidad de educar para toda a la vida. (VIÑAO, 2006, p. 46).

Outros autores progressitas vêem as reformas como mero estratagema de mudança, sem mexer na estrutura mais profunda da sociedade, de forma que tudo permanece igual. Guijarro Gutiérrez (1997; CAPEL, 1997) qualifica as reformas espanholas depois de 1970 de "reformismo lampedusiano", em alusão a idéia expressa pelo Príncipe de Lampedusa no romance O leopardo (II gatopardo). José

Os conceitos de "sociedade do conhecimento" e congêneres, como "sociedade da informação", serão analisados no capítulo 3 da parte I. 
María Rozada, ao analisar a sucessão de reformas na Espanha, concorda com Guijarro Gutiérrez e também faz referência ao mencionado caráter "lampedusiano" delas. Afirma ainda que à Educação sempre coube o papel de ser "la alegria de la huerta" (ROZADA, 2002, p. 17), ou seja, o papel de desviar a atenção sobre os verdadeiros problemas sociais.

O sociólogo Fernández Enguita (2006a) usa a mesma metáfora - mas fala em reforma "gatopardesca" - para denunciar esse papel dissimulador das reformas educativas. Embora defenda a necessidade delas, argumenta que reformar a Educação não é o mesmo que reformar a sociedade. A primeira reforma é parte da segunda, mas a segunda não pode reduzir-se à primeira. Se isso ocorre, como é freqüente, então a reforma educativa acaba "convertida en una reforma gatopardesca o menos que eso: cambiar algo para que nada cambie". (FERNÁNDEZ ENGUITA, 2006a, p. 220). Argumenta que as reformas educacionais são feitas para desviar a atenção da necessidade de reformas mais urgentes em outros setores da sociedade, como, por exemplo, na estrutura da propriedade e na distribuição de renda. Para Fernández Enguita (2006a, p. 221): "Se reforma la educación, pues, porque resulta menos costoso económicamente y menos conflictivo politicamente que reformar cualquier otra área relevante de la sociedad.". Enfim, muda-se a Educação para não mudar a sociedade.

Lerena (1999) também aponta o caráter diversionista das reformas educacionais, que servem para desviar a atenção de questões que se situam na sociedade de classes e nas relações de poder. Já Viñao (2006, p. 57) é menos cético, porém ainda assim afirma que:

[...] es obvio que una reforma educativa sólo puede introducir cambios y mejoras en la educación si va acompañada o, mejor aún, si esta inserta en un conjunto de medidas y cambios políticos, sociales, culturales e familiares del que dicha reforma es un aspecto o elemento más de las mismas.

Em seguida, alerta para o fato de que atuar somente sobre a Educação, sem tocar o resto dos sistemas, hábitos e espaços sociais, é assegurar que a reforma em questão passe à História como mais uma das reformas fracassadas (VIÑAO, 2006). 
Enfim, as reformas educativas fazem mais "ruído" do que trazem mudanças sociais efetivas, pelo simples fato de que atuam em uma dimensão das sociedades - a Educação - condicionada por outras dimensões, como a Política e a Economia, sobre as quais pouco podem interferir, pelo menos não diretamente e no curto prazo.

Como já foi dito, há vários tipos de reformas educacionais, entretanto uma das modalidades que mais desperta interesse e causa polêmica é a curricular. Isso porque está mais diretamente associada ao objeto principal de qualquer sistema de ensino: o conhecimento, suas concepções, sua seleção, sua difusão, enfim, ao "o que ensinar", "como ensinar", "como avaliar". Tendo isso em vista, é importante neste momento fazer uma primeira aproximação ao conceito de currículo (o conceito de conhecimento será discutido no capítulo 3 da parte I). 


\section{Currere $\rightarrow$ curriculum $\rightarrow$ currículo}

Currículo, do latim curriculum, deriva, para Goodson (2005), do termo scurrere, correr, e refere-se ao curso (ou carro de corrida). Pacheco (2005) diz que vem do étimo latino currere ${ }^{9}$ (caminho, jornada, trajetória, percurso a seguir). Kemmis (1998) afirma que, em latim, curriculum significava uma pista circular de atletismo (às vezes se traduz como "pista de corrida de carros"). Conforme Goodson (2005, p. 31): "As implicações etimológicas são que, com isso, o currículo é definido como um curso a ser seguido, ou, mais especificamente, apresentado.". Assim, o vínculo entre currículo e prescrição já vem de sua etimologia e com o tempo só foi reforçado com sua associação com disciplinas, classes e níveis. É interessante que, num dicionário comum, como o Houaiss (2008), a primeira acepção para currículo seja "ato de correr, corrida, curso" e que apenas na terceira acepção apareça "programação total ou parcial de um curso ou matéria a ser examinada". No Michaelis (1998), aparece como "1. ação de correr; 4. conjunto de matérias de um curso escolar". Portanto, no Brasil, nos principais dicionários e no senso comum, currículo é sinônimo de matérias de um curso. Em espanhol, o dicionário da Real Academia Española (2008) define currículo como "plan de estudios; conjunto de estudios y prácticas destinadas a que el alumno desarrolle plenamente sus posibilidades".

Embora sua matriz etimológica seja latina ${ }^{10}$, a palavra só foi utilizada pela primeira vez em 1633 na Universidade de Glasgow (GOODSON, 2005; KEMMIS, 1998). No Oxford English Dictionary, consta dessa época o registro mais antigo da acepção educacional da palavra curriculum. A utilização dessa palavra latina está nitidamente associada com o nascimento de uma seqüência completa e ordenada de escolarização. Na opinião de Kemmis (1998, p. 32-33):

9 O Dicionário Houaiss (2008) assinala que o substantivo latino curricùlum (corrida, carreira, lugar onde se corre $[. .]$.$) vem do verbo currère (correr).$

10 No mundo clássico, em lugar de curriculum, falava-se em trivium e quadrivium. O trivium, composto pelas disciplinas de lógica, gramática e retórica, era voltado para a formação básica dos cidadãos; o quadrivium, composto por aritmética, astronomia, geometria e música, para seu aperfeiçoamento. A educação das elites esteve assentada no trivium e no quadrivium até o final da Idade Média. 
Los términos primitivamente empleados para describir los cursos académicos fueron disciplina (utilizado por los jesuitas desde fines del Siglo XVI para manifestar un orden estructural más que secuencial) y ratio studiorun (que se refiere a un esquema de estudios, más que a una tabla secuencial de contenidos o syllabus). La palabra "curriculum" acaparó ambas connotaciones, combinándolas para producir la noción de totalidad (ciclo completo) y de secuencia ordenada (la metáfora del progreso en una carrera de atletismo) de estudios.

Por que em Glasgow?, indaga Goodson. Citando Hamilton e Gibbons, acredita que o senso de disciplina ou ordem estrutural que o currículo ganhou provém mais das idéias de João Calvino do que de sua origem clássica:

À medida que, no final do século XVI, na Suíça, Escócia e Holanda, os discípulos de Calvino conquistavam uma ascendência política e também teológica, a idéia de disciplina - "essência mesma do Calvinismo" - começava a denotar os princípios internos e o aparato externo do governo civil e da conduta pessoal. Dentro desta perspectiva percebe-se uma relação homóloga entre currículo e disciplina: o currículo era para a prática educacional calvinista o que era a disciplina para a prática social calvinista. (HAMILTON; GIBBONS, 1980, p. 15 apud GOODSON, 2005, p. 32).

Em seguida acrescenta, a título de especulação, que aqui se encontra um primeiro exemplo da relação entre conhecimento e controle. Kemmis (1998), tendo como referência os mesmos autores citados por Goodson, associa a utilização dessa palavra como parte do processo de transformação da educação da Universidade de Glasgow no início do século XVII.

Pacheco (2005), ao tentar conceituar o vocábulo "currículo", cita o mesmo trecho acima. Embora corroborando-o, chama de "interessante especulação de Goodson" a associação entre a emergência do currículo e o calvinismo. Em seguida acrescenta que, na perspectiva religiosa de João Calvino, a vida seria uma "corrida" ou uma "pista de corridas". Assim, de acordo com Pacheco (2005), Calvino teria se apropriado do termo curriculum para descrever a trajetória, o percurso, a forma de vida que os adeptos de sua doutrina deveriam seguir.

Kemmis (1998) não vê essa associação como especulação e acrescenta que o trabalho de Hamilton e Gibbons relaciona a emergência do termo curriculum a circunstâncias sociais, econômicas, políticas e históricas específicas: a época da Reforma Calvinista Escocesa. Assim, seria incorreto falar de curriculum, referindo-se à Educação, antes dessa época. 
A definição do conceito de currículo não é nada trivial ${ }^{11}$, é bem mais complexa e problemática. Trata-se de um conceito polissêmico que acabou banalizado no cotidiano das escolas, sendo associado simplesmente a programa ou plano. Na perspectiva dos professores, de forma geral, trata-se de uma noção externa, um programa imposto de fora, e nesse sentido fortemente reificada ${ }^{12}$ (e ideológica, claro), como fica patente nas palavras de Kemmis:

Para muchos profesores y para otras personas relacionadas con la escolarización, la noción de "curriculum" no plantea problemas: su significado es de por sí evidente. El "curriculum" se desarrolla con el trabajo mismo, tal y como viene. Se considera simplemente como la organización de lo que debe ser enseñado y aprendido. Con frecuencia, se toma como algo establecido fuera del marco de una determinada clase o escuela o, al menos, mediante un proceso de toma de decisiones en donde el profesor individual tiene poco que decir. Se piensa que se refiere a aquello que los profesores "tienen que" enseñar, sobre lo que ellos ejercen solamente un control muy limitado. Desde este punto de vista, difícilmente puede verse el curriculum como la realización de un proyecto educativo de un profesor o de una escuela para sus alumnos, su comunidad y la sociedad en su conjunto. (1998, p. 11, grifo do autor).

Estabelecer a sinonímia entre currículo e programa de conteúdos imposto de fora aos professores é uma primeira aproximação, entretanto limitante, porque não capta a relação dialética que se estabelece entre o que "está escrito" e o que é "posto em prática", entre o currículo manifesto e o currículo real.

A conceituação de currículo é problemática. Gimeno Sacristán (2000, p. 15-16) depois de fazer uma longa lista com uma mostra panorâmica dos significados tradicionais de currículo e de criticá-los, tenta dar sua definição:

O currículo é uma práxis antes que um objeto estático emanado de um modelo coerente de pensar a educação ou as aprendizagens necessárias das crianças e dos jovens, que tampouco se esgota na parte explícita do projeto de socialização cultural nas escolas. É uma prática, expressão da função socializadora e cultural que determinada instituição tem, que reagrupa em torno dele uma série de subsistemas ou práticas diversas, entre as quais se encontra a prática pedagógica desenvolvida em instituições escolares que comumente chamamos ensino.

Pacheco (2005) alerta para o fato de que insistir em uma definição abrangente de currículo pode ser extemporâneo e negativo, haja vista que não há

\footnotetext{
11 A palavra "trivial” tem a mesma raiz latina da palavra trivium. Num jogo de palavras, poderíamos dizer que a definição de currículo é no mínimo "quadrivial".

12 No capítulo 1 da parte I, a reificação será discutida como um dos modus operandi da ideologia, porém vale destacar desde já que o currículo como prescrição, reificado, é visto como algo dado, natural e, portanto, desprovido de contradições e de interesses antagônicos.
} 
um acordo sobre seu significado. Entretanto, não vê isso como algo negativo, ao contrário, para ele essa falta de consenso é um dos aspectos positivos do pensamento curricular, obrigando os especialistas a uma problematização cada vez mais frutífera. Em seguida acrescenta:

Existe, porém, consenso - o que permite falar de um campo epistemológico específico - quanto ao objeto de estudo, que é de natureza prática e ligado à educação, e quanto à metodologia, que é de natureza interdisciplinar, no quadro das ciências sociais e humanas. (PACHECO, 2005, p. 35).

Tanto José Gimeno Sacristán como José Pacheco seguem na mesma senda analítica trilhada antes por Shirley Grundy. Essa pesquisadora, após constatar que no capítulo inicial de muitas obras que tratam de currículo aparecem diversas conceituações idealistas, afirma:

Sin embargo, el curriculum no es un concepto, sino una construcción cultural. Es decir, no se trata de un concepto abstracto que tenga alguna existencia aparte de y antecedente a la experiencia humana. Es, en cambio, una forma de organizar un conjunto de prácticas educativas humanas. (GRUNDY, 1994, p. 19-20).

Reforçando esse argumento, vale lembrar que o termo já nasceu associado a uma "reforma" visando à transformação das práticas educativas da Universidade de Glasgow.

Enfim, o currículo, mais do que como um conceito, pode ser encarado como uma práxis, como uma construção social, mais especificamente educacional, e é assim que buscarei apreendê-lo no contexto das reformas espanhola e brasileira. Procurarei apreendê-lo sob o marco analítico da teoria crítica (que discutirei no próximo capítulo) e mais especificamente com base na teoria dos interesses cognitivos, proposta por Habermas (1994), o maior herdeiro daquela corrente de pensamento.

Buscando desvendar parte das contradições, dos conflitos de interesses políticos e econômicos permeados por enfrentamentos epistemológicos e ideológicos que atravessam as reformas educacionais, especialmente em sua modalidade curricular, utilizarei como método de abordagem a teoria crítica e a lógica dialética. 


\section{O MÉTODO: A DIALÉTICA E A TEORIA CRÍTICA}

\section{Introdução ao método}

A definição metodológica é uma das etapas mais importantes da pesquisa científica e deve ser o primeiro passo no processo de apreensão do objeto. É o método que define os caminhos a serem trilhados pelo pesquisador nesse processo. O método define a apreensão do objeto, mas o objeto também orienta a definição do método. Apesar de sua importância, reinam confusões, seja entre métodos e técnicas, seja entre método e teoria.

Para Sartre (2002, p. 20), "a filosofia caracteriza-se como um método de investigação e de explicação". Depreende-se disso que o método científico é transdisciplinar e sua base é a filosofia.

Porém, talvez mais importante do que definir um método de investigação e de explicação da realidade, seja operacionalizá-lo. Muitos trabalhos acadêmicos, não só na área de Geografia, definem a fundamentação teórico-metodológica em sua primeira parte; em seguida, o tratamento do objeto, a parte empírica, como é tradição especialmente em nossa disciplina, não incorpora o que foi definido a priori. Assim, saem dois trabalhos: um teórico, outro empírico; enfim, uma empresa metafísica, no sentido atribuído por Lefebvre (1991, p. 50), para quem "metafísicas" são "as doutrinas que isolam e separam o que é dado efetivamente como ligado". Aliás, como veremos, dicotomias "metafísicas", como teoria-prática, sujeito-objeto, sociedade-natureza, ainda são muito presentes nas ciências, especialmente na Geografia.

Há diversas definições de método, portanto pouco consenso entre os autores. Para Durozoi e Roussel (1996, p. 324):

O método designa um encaminhamento pelo qual se obtém um certo resultado, não necessariamente previsto de antemão, ou (é principalmente o sentido em Descartes) um conjunto de procedimentos ou de "regras" utilizados para chegar à meta desejada. 
Japiassu e Marcondes (2006) nos lembram que a palavra "método" deriva do latim tardio methodus, que vem do grego methodos, de meta (por, através de) e hodos (caminho). Assim, definem método como: "Conjunto de procedimentos racionais, baseados em regras, que visam atingir um objetivo determinado. Por exemplo, na ciência, o estabelecimento e a demonstração de uma verdade científica." (JAPIASSU; MARCONDES, 2006, p. 186).

Depreende-se dessas duas definições que método científico é sinônimo de método de procedimento: ambas falam em método como um "conjunto de procedimentos" para atingir uma meta ou um objetivo na ciência. Entretanto, deve-se estabelecer uma clara distinção entre método de abordagem e método de procedimento, como fazem Marconi e Lakatos (2005), ou entre método de interpretação e método de pesquisa, como fazem Moraes e Costa (1987). O método de abordagem ou de interpretação da realidade é a base filosófica, a visão de mundo do cientista, sua posição quanto às questões da lógica e da ideologia. Sua definição é importante para que o pesquisador possa se posicionar frente à realidade, frente ao objeto de pesquisa. O método de procedimento ou de pesquisa refere-se às técnicas de desenvolvimento da investigação, os passos que permitem operacionalizar o método de abordagem ou de interpretação da realidade.

É exatamente isso que diz Severino (2002, p. 162, grifo do autor), ao falar de métodos e técnicas: "Entende-se por métodos os procedimentos mais amplos do raciocínio, enquanto técnicas são procedimentos mais restritos que operacionalizam os métodos, mediante emprego de instrumentos adequados.". Mas a distinção entre método e técnica nem sempre é fácil, como argumenta Roger Brunet, embora também concorde que as técnicas são uma das formas de aplicação de um método:

Em geral, é difícil delimitar a diferença entre método e técnica. O primeiro termo impressiona mais e por isso muitas vezes é usado erroneamente no lugar do segundo. A técnica é acima de tudo uma das formas ou vias possíveis e práticas de se aplicar um método. (BRUNET et al., 2005, p. 328, tradução nossa).

Chama a atenção também para o fato de que é comum a confusão entre método e teoria; argumenta que o método é um instrumento da teoria. Poder-se-ia dizer, então, que a técnica é um instrumento do método. 
Habermas (1994), ao analisar a relação entre conhecimento e interesse, fala em ciências empírico-analíticas, nas quais está implicado um interesse técnico do conhecimento; ciências histórico-hermenêuticas, nas quais vigora um interesse prático; e ciências de orientação crítica, nas quais impera um interesse emancipatório. Para Sposito (2004), há três correntes teórico-metodológicas utilizadas na apreensão do real: empírico-analíticas, fenomenológico-hermenêuticas e crítico-dialéticas.

Severino (2001), por sua vez, menciona três dimensões do método. A primeira, de natureza epistêmica, está associada à subjetividade e às possibilidades do próprio conhecimento. A terceira, de natureza operacional, diz respeito às técnicas de pesquisa. Na segunda, uma articulação entre os elementos epistêmicos e técnicos, ele propõe o que chama de "metodologia", que se trata na prática do conjunto de procedimentos da pesquisa. Chama atenção para o fato de que:

[...] todo o investimento que vem sendo feito em termos de investigação científica na esfera da educação envolve-se profundamente, embora nem sempre de forma assumida e explícita, com os aspectos epistemológicos situados, obviamente, no plano dos pressupostos e das premissas. (SEVERINO, 2001, p. 13).

Ou seja, apesar de sua definição ser um tanto obscura, demonstra uma preocupação com o método de abordagem da realidade, situado no plano filosófico, no plano epistemológico.

Penso que é melhor falar simplesmente em método de abordagem e método de procedimento. Meu intento a seguir será definir o método de abordagem desta pesquisa, ancorado na lógica dialética e na teoria crítica, o investimento mais importante e mais complexo. No final deste capítulo farei uma breve explanação sobre o método de procedimento.

\title{
Método de abordagem
}

\author{
Os MÉTODOS CIENTÍFICOS
}


O método científico tornou-se dominante a partir da revolução científica do século XVI e foi sendo desenvolvido nos séculos seguintes. Vários pensadores e cientistas contribuíram para isso, entre os quais o matemático e astrônomo polonês Nicolau Copérnico (1473-1543), o físico e astrônomo pisantino Galileu Galilei (1564-1642) e o matemático e físico inglês Isaac Newton (1643-1727) (JAPIASSU; MARCONDES, 2006). Entretanto talvez a maior contribuição para a sistematização do método científico tradicional tenha sido dada pelo filósofo francês René Descartes (1596-1650). Na visão do sociólogo português Boaventura de Sousa Santos, o método científico, segundo o paradigma dominante oriundo das ciências naturais, está ancorado em pressupostos cartesianos. Em suas palavras:

As idéias que presidem à observação e à experimentação são as idéias claras e simples a partir das quais se pode ascender a um conhecimento mais profundo e rigoroso da natureza. Essas idéias são as idéias matemáticas. [...] Deste lugar central da matemática na ciência moderna derivam duas conseqüências principais. Em primeiro lugar, conhecer significa quantificar. $O$ rigor científico afere-se pelo rigor das medições. As qualidades intrínsecas do objeto são, por assim dizer, desqualificadas e em seu lugar passam a imperar as quantidades em que eventualmente se podem traduzir. O que não é quantificável é cientificamente irrelevante. Em segundo lugar, o método científico assenta na redução da complexidade. O mundo é complicado e a mente humana não o pode compreender completamente. Conhecer significa dividir e classificar para depois poder determinar relações sistemáticas entre o que se separou. (SOUSA SANTOS, 2002, p. 60).

No trecho acima, ficam evidentes as referências à segunda e à terceira regra do Discurso do método de Descartes, essa "maravilhosa autobiografia espiritual", segundo Sousa Santos (2002, p. 61). O sociólogo português identifica em Descartes a origem de duas das regras básicas do método científico: dividir o que é complicado de ser apreendido para facilitar o entendimento e iniciar do mais simples e fácil para o mais complexo e difícil. Nas palavras do próprio Descartes ${ }^{13}$ (1978, p. 40):

13 O Discurso do método foi publicado pela primeira vez em 1637. A citação que aparece aqui é da $14^{\mathrm{a}}$ edição de uma publicação mexicana de 1978, cuja primeira edição data de 1937. Assim como neste caso, vão aparecer outros em que o ano da publicação consultada (conforme normas de citação) será muito mais recente do que o da obra original. Para minimizar esse problema, procurarei mencionar ao longo do texto a data de publicação original das obras clássicas citadas. Apenas para registrar: na primeira regra do método, Descartes (1978) reafirma a crença na razão, evitando a precipitação e o prejulgamento; na quarta, destaca a importância de revisões para assegurar um bom resultado da pesquisa. 
El segundo, dividir cada una de las dificultades que examinare, en cuantas parte fuere posible y en cuantas requiriese su mejor solución.

El tercero, conducir ordenadamente mis pensamientos, empezando por los objetos más simples y más fáciles de conocer, para ir ascendiendo poco a poco, gradualmente, hasta el conocimiento de los más compuestos, e incluso suponiendo un orden entre los que no se preceden naturalmente.

A ligação entre Filosofia e Ciência, através do método, se manifesta em várias passagens, de diversos pensadores. Sartre (2002, p. 21) reafirma isso, reforçando o que já foi mencionado na introdução deste trabalho, e busca em Descartes o primeiro "momento" desta ligação:

Se a filosofia deve ser, a uma só vez, totalização do Saber, método, Idéia reguladora, arma ofensiva e comunidade de linguagem; se essa "visão do mundo" é também um instrumento que trabalha as sociedades carcomidas, se essa concepção singular de um homem ou de um grupo de homens torna-se a cultura e, às vezes, a natureza de uma classe inteira, fica bem claro que as épocas de criação filosófica são raras. Entre os séculos XVII e XX, vejo três que designarei por nomes célebres: existe 0 "momento" de Descartes e de Locke, o de Kant e de Hegel e, por fim, o de Marx. Essas três filosofias tornam-se, cada uma por sua vez, o húmus de todo o pensamento particular e o horizonte de toda a cultura, elas são insuperáveis enquanto o momento histórico de que são a expressão não tiver sido superado.

Seguindo essa trajetória traçada por Sartre, o método começa com a metafísica, baseada na lógica formal de Descartes; passa pela metafísica de Hegel, porque ainda baseada numa dialética idealista; para chegar à dialética materialista de Marx. Lembrando com Lefebvre (1991, p.52) que a metafísica "consiste sempre numa teoria desligada da prática, sem unidade com a prática, sem ligação direta e consciente com a mesma. A metafísica encontra seu domínio favorito da vida real nas nuvens, num além do mundo físico". Porém, nessa trajetória linear Sartre (2002) não mencionou o filósofo francês Augusto Comte (1798-1857), criador do positivismo, método mais influente nas ciências naturais, nas ciências empíricoanalíticas.

O grande problema foi que, ao longo da História do desenvolvimento do conhecimento, buscou-se aplicar às ciências sociais os mesmos métodos desenvolvidos para as ciências naturais. A Geografia, em particular, sofreu muito com isso e, com sua indefinição entre ciência humana ou natural, ficou durante muito tempo sob o jugo positivista. De acordo com Boaventura, para o positivismo "só há duas formas de conhecimento científico - as disciplinas formais da lógica e 
da matemática e as ciências empíricas segundo o modelo mecanicista das ciências naturais". (SOUSA SANTOS, 2002, p. 65). Aprisionadas dentro do modelo mecanicista das ciências naturais, já que não se encaixavam nos paradigmas da lógica e da matemática, as ciências sociais nasceram para ser empíricas. Esse autor distingue duas fases do desenvolvimento metodológico das ciências sociais:

[...] a primeira, sem dúvida dominante, consistiu em aplicar, na medida do possível, ao estudo da sociedade, todos os princípios epistemológicos e metodológicos que dominavam o estudo da natureza desde o século XVI; a segunda, durante muito tempo marginal mas hoje cada vez mais seguida, consistiu em reivindicar para as ciências sociais um estatuto epistemológico e metodológico próprio, com base na especificidade do ser humano e na sua distinção radical em relação à natureza. (SOUSA SANTOS, 2002, p. 65).

Essa segunda fase abriu possibilidades para o desenvolvimento de outras correntes metodológicas, como o materialismo dialético, mas isso apenas a partir do final do século XIX. Como veremos mais adiante, não deixa de ser curioso que Engels, na contramão desse processo, tenha tentado aplicar à natureza um método - a dialética - que nasceu nas ciências sociais.

Descartes enunciou quatro regras de método, mas foi a segunda, na qual propõe dividir o objeto de estudo para sua melhor apreensão, que se tornou o principal pilar do método científico, pelo menos do positivista. Como assevera Sousa Santos (2002, p. 65): "A consciência filosófica da ciência moderna, que tivera no racionalismo cartesiano e no empirismo baconiano as suas primeiras formulações, veio a condensar-se no positivismo oitocentista.".

Milton Santos, em seu livro Espaço e método, ao buscar definir um método de apreensão da realidade geográfica, também faz uma remissão à segunda regra cartesiana quando afirma:

O espaço dever ser considerado como uma totalidade, a exemplo da própria sociedade que lhe dá vida. Todavia, considerá-lo assim é uma regra de método cuja prática exige que se encontre, paralelamente, através da análise, a possibilidade de dividi-lo em partes. Ora, a análise é uma forma de fragmentação do todo que permite, ao seu término, a reconstituição desse todo. (SANTOS, 1997, p. 5).

Eis um problema que historicamente acompanha as ciências "positivas" e a Geografia recebeu muito desta influência -, em grande medida ainda 
aprisionadas à metafísica, à lógica formal: muitas vezes, o objeto é fragmentado e depois não é reconstituído. Ou seja, como diz Lefebvre (1991), sua apreensão fica no nível do entendimento, da análise, que fragmenta o objeto, que vê a parte; não chega no nível da razão, da síntese, que restabelece as relações, que vê o todo. A análise é a morte do objeto, sua negação; a síntese é a vida do objeto, sua afirmação, como bem sabia Milton Santos, conhecedor da obra de Henri Lefebvre. No movimento do conhecimento, entendimento e razão não estão separados, mas em interação dialética.

Sartre (2002), mesmo criticando o marxismo ortodoxo, sua instrumentalização pelo Estado comunista e a subsunção do homem à História (contra o que propôs o existencialismo), nunca negou a importância do "momento" de Marx na filosofia e sua contribuição ao método de interpretação da realidade, com a dialética materialista.

O método dialético tem muito a contribuir para as Ciências Humanas, especialmente para a área da Educação, como veremos. Há diversos educadores de variadas nacionalidades, entre os quais estudiosos do currículo, que defendem uma abordagem crítico-dialética para a área educacional (APPLE, 2006; FREIRE, 2005, 2006; GIMENO SACRISTÁN, 1999, 2000, 2006; GRUNDY, 1994; PACHECO, 1996, 2005; SEVERINO, 2001). Isso se deve ao caráter histórico-social e cultural da Educação, ao fato de ser uma prática teleológica impulsionada por sujeitos conscientes. Deve-se a seu caráter eminentemente práxico (FREIRE, 2005, 2006; SEVERINO, 2001), ou seja, ao fato ser ao mesmo tempo ação e reflexão, teoria e prática. Consideram ainda que o currículo expressa uma relação dialética escolasociedade-cultura.

O brasileiro Antônio Severino, depois de criticar o paradigma tradicional da ciência, ancorado nas ciências naturais, a exemplo do que fez Sousa Santos (2002), e afirmar que este é inadequado para estudos na área educacional, defende que:

[...] quando entramos no campo da ciência da educação, impõe-se agregar um outro elemento do olhar científico, que possa dar conta da praxidade de seu objeto, ou seja, do caráter eminentemente práxico da educação. Ora é o paradigma dialético que tem 
se revelado, até o momento, como a perspectiva mais fecunda para responder a esse desafio. (SEVERINO, 2001, p. 17, grifo nosso).

O espanhol José Gimeno Sacristán, seguindo na mesma linha, assevera:

O currículo modela-se dentro de um sistema escolar concreto, dirige-se a determinados professores e alunos, serve-se de determinados meios, cristaliza, enfim, num contexto, que é o que acaba por lhe dar o significado real. Daí que a única teoria possível que possa dar conta desses processos tenha de ser do tipo crítico, pondo em evidência as realidades que o condicionam. (2000, p. 21, grifo nosso).

O norte-americano Michael Apple, no prefácio à edição de $25^{\circ}$ aniversário de seu influente livro Ideologia e currículo, também defende o paradigma crítico como método de abordagem em Educação (ao mesmo tempo em que critica a abordagem técnica), por encará-la como uma relação dialética com a sociedade. Para ele:

[...] um estudo verdadeiramente crítico da educação precisa ir além das questões técnicas de como ensinar eficiente e eficazmente - que são em geral as questões dominantes ou únicas questões levantadas pelos educadores. Esse estudo deve pensar criticamente a relação da educação com o poder econômico, político e cultural. (APPLE, 2006, p. 7, grifo nosso).

No decorrer do mesmo livro explicita mais claramente seu método de abordagem e sua filiação ao marxismo. Para isso, utiliza categorias de análise caras a essa corrente de pensamento, como ideologia e hegemonia, e destaca as relações entre Educação e Economia, conhecimento e poder. Para compreender essas questões, que para ele são estruturais, Apple (2006) diz lançar mão de uma tradição neomarxista de argumentação, que lhe parece o modelo mais convincente para organizar o pensamento e a ação relativos à Educação.

Concordo com esses autores sobre a relevância do "paradigma dialético", de uma "teoria do tipo crítico" ou de um "estudo verdadeiramente crítico" para o desenvolvimento de pesquisas na área educacional. Entretanto, pelo menos na bibliografia consultada, não explicitam claramente o que seria o método crítico ou dialético. Como é relativamente comum, não se preocupam em fazer uma genealogia do método adotado em suas pesquisas. Assim, falar, como faz Apple, (2006) que seguirá uma tradição neomarxista de argumentação é um tanto vago. 
Como nos lembra Moraes (2000), nessa tradição poderia se falar em "leninistas", em "trotskistas", em "lukacsianos", em "austromarxistas". Nessa lista acrescentaria a "teoria crítica".

Por isso procurarei definir o mais claramente possível a fundamentação teórico-metodológica deste trabalho. Pretendo elaborar um método de abordagem ancorado nos pressupostos da teoria crítica, especialmente com base no modelo crítico iniciado por Max Horkheimer, e da lógica dialética, como foi (re)formulada por Henri Lefebvre.

\section{O MÉTODO DIALÉTICO}

O método dialético ou materialismo dialético, muitas vezes é situado como sinônimo de marxismo, porque esse método de abordagem da realidade foi desenvolvido por diversos teóricos, com base nas formulações de Marx e Engels, embora, muito provavelmente, Marx não tivesse concordado com essa sinonímia, especialmente após o materialismo dialético ter sido alçado à condição de "método" de um partido, de um Estado. Com o stalinismo, o materialismo dialético petrificouse, deixou de ser um método de interpretação e passou a ser um "método" de deturpação da realidade, operando uma cisão entre teoria e prática. Isso é apontado por Sartre (2002) em sua Crítica da razão dialética.

Para o filósofo existencialista francês, o marxismo, instrumentalizado pelo Estado soviético, deturpou completamente o método dialético, foi metafísico e, pior, idealista absoluto porque "submetiam-se a priori os homens e as coisas às idéias; se a experiência não confirmava as previsões, é porque estava equivocada." (SARTRE, 2002, p. 31).

Lefebvre (1991, p. 23) também denunciou a fossilização da dialética sob o stalinismo:

De conhecimento, aquele dos movimentos históricos, e de projeto revolucionário para transformar o "mundo", o pensamento dialético se converte em projeto de ação estatal para coagular 0 mundo, estancando a história: destruição do movimento, autodestruição de si enquanto movimento, afirmação enquanto metalinguagem. 
Segundo Aron (2005), a expressão "materialismo dialético" não é encontrada, ou talvez raramente, nos escritos de Marx, nem em obras de sua juventude, nem nas de sua maturidade. O termo vai aparecer, sob a pena de Engels, na segunda parte de sua existência, especialmente no Anti-Dühring, publicado em 1878.

Nesse livro, Engels reconhece que Hegel foi o primeiro a conceber 0 mundo da natureza, da História e do espírito como processo, como movimento, embora ainda à sua maneira idealista. Feito isso, afirma que a consciência da inversão promovida pelo idealismo alemão necessariamente levaria ao materialismo. Para ele "o materialismo moderno é substancialmente dialético e já não há necessidade de uma filosofia superior para as demais ciências". (ENGELS, 1990, p. 23). Disse mais, naquele estilo provocativo, quase arrogante, que the era peculiar: "Marx e eu fomos, sem dúvida alguma, os únicos que salvaram da filosofia idealista alemã a dialética consciente, incluindo-a na nossa concepção materialista da natureza e da história." (ENGELS, 1990, p 10).

De acordo com Aron (2005), na fecunda parceria de Marx e Engels, aquele acabou desempenhando mais o papel de economista e esse mais o de filósofo. Os textos filosóficos de Marx praticamente estão restritos ao livro Ideologia alemã, escrito entre 1845-1846 em parceria com Engels (só publicado em 1930, por divergências com os editores). Marx escreveu o capítulo 1, "Feuerbach", e Engels 0 restante da Ideologia alemã.

Entretanto, é importante lembrar que, sob o método rotulado como "marxismo", a interpretação materialista da História no livro Ideologia alemã, como enunciada no trecho a seguir, ainda não é a interpretação dialética do livro AntiDühring. Esta, embora com a anuência de Marx, foi desenvolvida por Engels.

A produção das idéias, representações, da consciência está a princípio diretamente entrelaçada com a atividade material e o intercâmbio material dos homens, linguagem da vida real. O representar, o pensar, o intercâmbio intelectual ${ }^{14}$ dos homens aparecem aqui ainda como afluxo direto do seu comportamento material. O mesmo se aplica à produção intelectual como se apresenta na linguagem da política, das leis, da moral, da religião, da metafísica etc., de um povo. [...]

14 No texto original estava intercâmbio espiritual e produção espiritual; optamos por intelectual como consta da tradução da coletânea organizada por Florestan Fernandes (2003, p. 192). 
Em completa oposição à filosofia alemã, a qual desce do céu à terra, aqui se sobe da terra ao céu. Isto é, não se parte daquilo que os homens dizem, imaginam ou se representam, e também não de homens narrados, pensados, imaginados, representados, para daí se chegar aos homens em carne e osso; parte-se dos homens realmente ativos e com base no seu processo real de vida apresenta-se 0 desenvolvimento dos reflexos e ecos ideológicos deste processo de vida. (MARX; ENGELS, 1981, p. 29).

Depois dessa crítica ao idealismo, Marx e Engels (1981, p. 30) enunciam a principal máxima do materialismo: "Não é a consciência que determina a vida, é a vida que determina a consciência.". Essa inversão, ou desinversão - esse "subir da terra ao céu" - deixará marcas profundas no método de interpretação das relações sociais no processo histórico. A junção do materialismo com a dialética redundará num método que será a base do "marxismo de Marx", no dizer de Aron (2005), e nos "marxismos" descendentes dele.

Agora, a questão central na discussão sobre o método dialético, que por definição é materialista, é responder: o que é dialética? Para Lefebvre (1991, p. 21): "A lógica dialética acrescenta, à antiga lógica, a captação das transições, dos desenvolvimentos, da 'ligação interna e necessária' das partes no todo.”. Segundo ele, só há dialética se existir movimento e só há movimento se existir processo histórico: História.

Raymond Aron, no livro O marxismo de Marx, define a dialética como sendo:

[...] uma concepção materialista das relações entre a realidade que é dada e o pensamento que elaboramos a partir da realidade, sendo esse pensamento cópia ou reflexo da realidade. A dialética não se define de maneira prioritária pela intervenção do homem, do pensamento ou da força negativa do espírito; ela se define como uma característica da própria realidade natural. A realidade natural é dialética porque está em movimento, porque as coisas se tornam, porque as coisas nascem e acabam. (ARON, 2005, p. 479).

Aron buscou essa concepção de dialética em Engels, no Anti-Dühring. Então, vamos à fonte. Para Engels, a natureza e a sociedade sempre foram dialéticas, antes mesmo que os homens soubessem. De acordo com ele, coube a Hegel descobrir as leis da dialética:

Muito antes de saber o que era dialética, o homem já pensava dialeticamente, da mesma forma porque, muito antes da existência da palavra escrita, ele já falava. Hegel 
nada mais fez que formular nitidamente, pela primeira vez, esta lei da negação da negação, lei que atua na natureza e na História, como atuava, inconscientemente, em nossos cérebros, muito antes de ter sido descoberta. (ENGELS, 1990, p. 121).

Enfim, a dialética faz parte da sociedade e da História, ou seja, do movimento da vida, e cabe ao pesquisador desvendá-la. Claro, aqui estamos falando da dialética hegeliana, porque em sua origem platônica essa palavra significava a arte do diálogo como método de interrogação, talvez elaborado por Zenão de Eléia, praticada por Sócrates e cuja colocação em forma literária foi feita por Platão (DUROZOI; ROUSSEL, 1996).

O trecho transcrito na página anterior explicita um acirrado debate travado entre os seguidores de Marx e Engels e especialmente entre seus críticos. Há mesmo uma dialética da natureza? Ou a dialética só é aplicável às ciências sociais?

$\mathrm{Na}$ introdução à Dialética da Natureza, livro inconcluso publicado após sua morte em 1895, Engels não deixa dúvidas de que sua resposta para as duas perguntas é afirmativa:

As leis da dialética são, por conseguinte, extraídas da história da Natureza, assim como da história da sociedade humana. Não são elas outras senão as leis mais gerais de ambas essas fases do desenvolvimento histórico, bem como do pensamento humano. (ENGELS, 2000, p. 34).

Em outro trecho, o filósofo materialista alemão justifica o porquê da produção daquele livro: tentar mostrar a existência da dialética nas ciências naturais. Em suas palavras: "Não nos propomos redigir um tratado de dialética, mas apenas ressaltar que as leis dialéticas são leis reais do desenvolvimento da Natureza e, por conseguinte, válidas no que diz respeito à teoria das ciências naturais." (ENGELS, 2000, p. 34-35).

Entre os autores que não acreditam em uma dialética da natureza, situam-se nomes de peso, como Sartre (2002). Para o filósofo existencialista francês, se algo como uma razão dialética existe, ela só faz sentido se estiver associada à práxis humana, aos homens situados em determinada sociedade em movimento, portanto uma dialética da natureza não passa de uma hipótese metafísica. Finaliza suas críticas apontando o erro de Engels em seu livro Dialética da Natureza: 
O erro de Engels, no texto citado, consiste em ter acreditado que podia extrair suas leis dialéticas da Natureza por meio de procedimentos não dialéticos: comparações, analogias, abstrações, indução. De fato, a Razão dialética é um todo e deve fundamentar-se em si própria, isto é, dialeticamente. (SARTRE, 2002, 154-155).

Ou seja, para Sartre, Engels procurou a dialética onde não existia e, pior, não foi dialético em sua procura. Lefebvre, por sua vez, também acreditava na possibilidade de uma dialética na natureza quando escreveu:

A lógica concreta, ou teoria dessas leis universais do movimento no pensamento e no real, é o resumo de todo o conhecimento (de toda a história do conhecimento) e também da natureza. Ela resume ao mesmo tempo, como anunciamos, experiências humanas inumeráveis e exigências racionais. Da razão dialética, pode-se dizer que ela "é" dialética no sentido pleno da palavra "ser". Não apenas supera o pensamento formal e o entendimento, mas funda-se diretamente, imediatamente, sobre 0 conhecimento da natureza e sobre a própria natureza. É dialética porque a natureza "é" dialética. (LEFEBVRE, 1991, p. 186, grifo do autor).

Porém, seu conceito de natureza é ampliado em relação à concepção original do pensamento marxista, ou pelo menos como está proposto por Engels (2000) no Dialética da Natureza. É ampliado mesmo em relação ao que Sartre (2002) considera natureza no Crítica da razão dialética. Tanto para Engels como para Sartre, natureza é apenas o mundo natural. Refutando as dicotomias típicas da lógica formal e da metafísica, para Lefebvre (1991) o homem e sua obra, construída a partir da natureza natural, compõem a natureza.

A dialética é uma lógica da sociedade, no entanto, como a sociedade se relaciona com a natureza, em sentido strictu ou em sentido lato, vive dela, a transforma e interfere nos processos naturais, uma dialética da natureza só poderia ser uma dialética da relação sociedade-natureza. Uma segunda natureza, e, evidentemente, sob os auspícios do homem. É isso, creio, que o filósofo existencialista quis dizer ao afirmar: "é no interior de uma sociedade que já possui suas ferramentas e instituições que descobriremos os fatos materiais - pobreza ou riqueza do subsolo, fator climático etc. - que a condicionam e em relação aos quais ela própria se definiu”. (SARTRE, 2002, p. 153, grifo do autor).

Mas, como dar conta das leis da dialética, como propõe Engels, na apreensão do movimento da realidade e do conhecimento? Para ele, há três leis: "1) 
A lei da transformação da quantidade em qualidade e vice-versa; 2) A lei da interpenetração dos contrários; 3) A lei da negação da negação." (ENGELS, 2000, p. $34)$.

Sartre, depois de citar essas mesmas três leis, lembrando que foram desenvolvidas por Hegel, à sua maneira idealista, como simples leis do pensamento, questiona Engels: "Por que existem três leis, em vez de dez ou uma só? Por que as leis do pensamento são aquelas e não outras? De onde vêm?" (SARTRE, 2002, p. 152).

Lefebvre (1991, p. 237-239), por sua vez, fala em cinco leis do método dialético:

a) lei da interação universal (da conexão, da "mediação" recíproca de tudo o que existe). [...]

b) lei do movimento universal. [...]

c) lei da unidade dos contraditórios. [...]

d) transformação da quantidade em qualidade (lei dos saltos). [...]

e) lei do desenvolvimento em espiral (da superação).

A lei da interação universal evidencia que, na realidade, nada é isolado, que cada fenômeno existe dentro de um conjunto de relações e que isolá-lo pelo entendimento metafísico é privá-lo de sentido, de conteúdo, é não apreendê-lo em sua essência. Essa proposta é, em termos filosóficos, exatamente o oposto da segunda regra do método cartesiano que impregnou a ciência moderna.

A lei do movimento universal enuncia que, ao apreender os fenômenos no seu conjunto, o método dialético reintegra-os em seu movimento: no movimento interno, oriundo deles mesmos, e no movimento externo, dado pelo devir universal. Busca penetrar (apreender) no que já tende para seu fim e no que já anuncia seu nascimento. Busca o movimento profundo (essência) que se oculta sob o movimento superficial.

A lei da unidade dos contraditórios corresponde à segunda lei enunciada por Engels (2000). Prega que, diferentemente da lógica formal, que mantém os contraditórios à margem um do outro, numa relação de exclusão, a contradição dialética é uma inclusão dos contraditórios um no outro; e ao mesmo tempo, é uma exclusão ativa. Nas palavras de Lefebvre (1991, p. 238): "O método dialético busca captar a ligação, a unidade, o movimento que engendra os 
contraditórios, que os opõe, que faz com que se choquem, que os quebra ou os supera.". A vida, a realidade, é plena de contradições, mas como ele nos alerta:

Não existe, dialeticamente, a "contradição" em geral; existem contradições, cada qual com seu conteúdo concreto, com seu movimento próprio, que deve ser penetrado em suas conexões (cf. a $2^{\mathrm{a}}$ lei), em suas diferenças e semelhanças. (LEFEBVRE, 1991, p. 238).

Enfim, as contradições devem ser buscadas na realidade, no universal concreto, no movimento da História.

A lei da transformação da quantidade em qualidade, a primeira enunciada por Engels (2000), é talvez a lei mais fácil de perceber na natureza. É sintomático, aliás, que ele tenha enunciado três leis no Dialética da Natureza, mas desenvolvido só a primeira. Com exemplos da Química e da Física, afirmava que as mudanças qualitativas só podem se realizar por acréscimos ou por subtração quantitativa de matéria ou de movimento. Citando Hegel, Engels diz que o exemplo mais recorrente disso é o da mudança de estado da água em função da variação da temperatura.

Assim, por exemplo, o grau de temperatura da água é, no começo, indiferente quanto ao seu estado líquido; mas, ao aumentar ou diminuir a temperatura da mesma, chegará um ponto em que seu estado de coesão se modifica e a água é transformada em vapor ou gelo. (HEGEL, Obras Completas, t. VI, p. 217 apud ENGELS, 2000, p. 36).

Lefebvre não dá nenhum exemplo dessa lei, nem na natureza nem na sociedade, embora admita que ela é válida para ambas. Limita-se a dizer que essa, que ele também chama de lei dos saltos, é a grande lei da ação. Ou seja, valoriza o sujeito, o movimento e o devir.

O momento da ação, do fator "subjetivo", aparece quando - reunidas já todas as condições objetivas - basta um fraco impulso proveniente do "sujeito" para que o salto se opere. Isso pode ocorrer em todos os tipos de dispositivos experimentais (onde basta apertar um botão, fazer passar uma fraca corrente elétrica, etc.), bem como na vida psicológica e social. (LEFEBVRE, 1991, p. 239).

Lembrando Hegel, afirma que o conjunto de transformações solidárias forma uma "linha nodal" e que a crise de uma civilização, por exemplo, pode consistir numa crise da cultura, da economia, da política, da vida social, do 
pensamento. Cada crise tem suas particularidades. Para Lefebvre (1991, p. 239): "O salto dialético implica, simultaneamente, a continuidade (o movimento profundo que continua) e a descontinuidade (o aparecimento do novo, o fim do antigo).".

Talvez a lei mais identificada com a dialética seja a terceira enunciada por Engels (2000), a lei da negação da negação ou, como denomina Lefebvre (1991), a lei do desenvolvimento em espiral (ou da superação). Assim como o método cartesiano ficou mais conhecido pela segunda regra, o método dialético ficou mais conhecido pela terceira lei (das três enunciadas por Engels). É a conhecida fórmula da tese-antítese-síntese, que Lefebvre chama de movimento em espiral. No movimento do pensamento, em sua relação com a sociedade, sempre ocorre um retorno acima do superado para dominá-lo e aprofundá-lo, para elevá-lo de nível, libertando-o de seus limites. Para o filósofo marxista francês:

A contradição dialética é já "negação" e "negação da negação", visto que as contradições estão em luta efetiva. Desse choque, que não é um choque "no pensamento", no abstrato, no plano subjetivo (embora dê lugar a um "choque de pensamentos"), surge uma promoção mais elevada do conteúdo positivo que se revela e se libera no e pelo conflito. (LEFEBVRE, 1991, p. 240).

Em suma, a negação da negação é uma lei da realidade e não do pensamento, como muitas vezes se imagina, embora ela também se manifeste no pensamento, na medida em que este é uma tentativa de apreender a realidade.

Lefebvre (1991) chama a atenção para o fato de que essas leis dialéticas constituem pura e simplesmente uma análise do movimento e apresentam uma unidade fundamental. Porém, lembra que cada uma delas pode ter maior ou menor destaque dependendo do objeto a ser apreendido, que nesse processo a ênfase pode ser posta, alternadamente, sobre essa ou aquela lei. Em certos casos, a lei da contradição - a negação da negação - será mais conveniente para a análise, pois na contradição está a raiz, o fundamento do movimento sócio-histórico. Mas as próprias contradições resultam de um movimento mais profundo que as condiciona, as atravessa, e para desvendá-lo entra em ação a lei da interação universal.

O método deve apreender o particular do universal concreto e suas leis devem ser concretas no sentido de que permitam apreender o objeto, a realidade em movimento. O método deve expressar leis do real e leis do pensamento; leis do 
movimento da matéria e leis da idéia. Enfim, o método deve ser operacional e heurístico. Penso que a dialética é, especialmente associada à teoria crítica. Como diz Freitag (2004, p. 48): "a dialética, elemento constituinte da teoria crítica, nunca se contenta com o presente ou com o status quo, mas representa o esforço permanente de superar a realidade cotidiana rotinizada".

Entretanto, devo admitir que soa estranho falar em "leis da dialética", afinal a palavra "lei" está fortemente associada às ciências empírico-analíticas e à idéia de controle. Em um dicionário comum, a primeira definição de lei é "regra categórica", sob a rubrica filosofia consta como "expressão definidora das relações constantes que existem entre os fenômenos naturais, como, por exemplo, o enunciado de uma propriedade física verificada de maneira precisa" (HOUAISS, 2008). Daí se falar em leis da física, da química, da astronomia etc.

Durozoi e Roussel (1996, p. 281) definem lei científica, ou lei da natureza (eles fazem essa sugestiva ressalva), "como uma relação invariável, constante e mensurável entre os fenômenos". Para Japiassu e Marcondes (2006, p. 165, grifo do autor): "Lei científica: aquela que estabelece, entre os fatos, relações mensuráveis, universais e necessárias, permitindo que se realizem previsões.". Todos eles não explicitam, mas estão falando de um certo tipo de ciência, orientada por determinado interesse, que não tem nada de dialético. Portanto, vou tomar como licença metodológica o uso da palavra lei associada à dialética, como fizeram Engels (2000) e Lefebvre (1991). Aliás, nesse caso, a palavra "leis" deveria vir sempre entre aspas. Assim como não faz sentido falar em "leis" da dialética, faz muito menos ainda falar em dialética da natureza, essa sim regida por leis, sem aspas. Dialética é uma lógica que busca apreender o movimento sócio-histórico, que, por definição, é imprevisível, irregular, contraditório, prenhe de múltiplas determinações, em uma palavra: dialético.

Assim, vou lançar mão da lógica dialética neste trabalho para buscar apreender o movimento sócio-histórico das reformas educacionais no Brasil e na Espanha, já que são impulsionadas por sujeitos conscientes. Com isso, vou procurar desvendar suas interações e conexões no interior de cada sociedade, suas contradições e a possível superação. Gostaria de lembrar, finalmente, que não é 
possível, no movimento do conhecimento humano e, portanto, numa pesquisa que busque apreendê-lo, ser dialético o tempo todo.

\section{A teoria CRítica}

A teoria crítica foi formulada inicialmente por Max Horkheimer no ensaio Teoria tradicional e teoria crítica, publicado em 1937. Ele foi o primeiro a formular essa idéia na forma de um conceito, em oposição à idéia de teoria tradicional (NOBRE, 2008). Em outro ensaio - Filosofia e teoria crítica -, escrito em resposta aos julgamentos suscitados e como contribuição ao debate que seguiu, Horkheimer deixou claro que a teoria crítica segue a tradição marxista de argumentação e foi inspirada na crítica da economia política de Karl Marx.

Em meu ensaio "Teoria tradicional e teoria crítica" apontei a diferença entre dois métodos gnosiológicos. Um foi fundamentado no Discours de la méthode, cujo jubileu de publicação se comemorou neste $a 0^{15}$, e o outro, na crítica da economia política. (HORKHEIMER, 1980b, p. 155).

A teoria tradicional, objeto de sua crítica, tem origem no racionalismo cartesiano, espinha dorsal da ciência moderna, passando pelo positivismo, e baseiase nas idéias matemáticas, na quantificação, como já nos falou Sousa Santos (2002). Disso resulta uma das características mais importantes da ciência moderna: a separação sujeito-objeto, a exterioridade do sujeito frente ao objeto. Para Horkheimer, essa separação não existe:

A teoria crítica da sociedade, ao contrário, tem como objeto os homens como produtores de todas as suas formas históricas de vida. As situações efetivas, nas quais a ciência se baseia, não é [sic] para ela uma coisa dada, cujo único problema estaria na mera constatação e previsão segundo as leis da probabilidade. O que é dado não depende apenas da natureza, mas também do poder do homem sobre ela. (1980b, p. 155).

15 Horkheimer se refere a 1937, ano da publicação do referido artigo na Zeitschrift fuer Sozialforschung. (N. dos T.) 
A teoria crítica geralmente é associada à Escola de Frankfurt $^{16}$,
aparecendo muitas vezes como seu sinônimo, mas extrapolou os teóricos geralmente associados ao Instituto de Pesquisa Social. O que há em comum aos seguidores dessa linha teórico-metodológica é a filiação crítica, não dogmática, ao marxismo. Referindo-se ao artigo Teoria tradicional e teoria crítica, Roith (2007) afirma que esse título tem um intento camuflador: ao evitar a denominação de teoria marxista, evidencia que Horkheimer e seus colaboradores já não se identificavam com a teoria marxista em sua forma ortodoxa.

Com o passar do tempo vai havendo um crescente distanciamento crítico em relação ao pensamento original de Marx, até que Horkheimer e Adorno se vêem em um impasse metodológico-filosófico, como discutiremos a seguir, ao depararem com a impossibilidade de uma revolução proletária, com o completo bloqueio à emancipação na forma pensada por Marx. Freitag (2004, p. 39-40), comentando a argumentação de Horkheimer no artigo Teoria tradicional e teoria crítica, afirma:

Como se pode ver, Horkheimer se encontra, nessa argumentação, ainda muito próximo de Marx, como aliás todos os trabalhos do Instituto publicados na Zeitschrift nessa época. Essa proximidade vai sendo minada no decorrer dos anos subseqüentes, nos quais Horkheimer perde toda e qualquer esperança em relação à possibilidade e necessidade de uma revolução proletária.

A teoria crítica está ancorada em quatro pressupostos principais que the dão singularidade em termos metodológicos: o comportamento crítico, a orientação para a transformação social e a emancipação humana, a análise critica do momento presente, mas orientada para o futuro, e a auto-reflexão ou autocrítica (FREITAG, 2004; HORKHEIMER, 1980a, NOBRE, 2004, 2008). Nesse sentido, todo pesquisador que manifestar essas preocupações em sua práxis, que em sua atividade seguir no todo ou em parte esses pressupostos, pode ser considerado um

16 Escola de Frankfurt é o nome pelo qual ficou conhecido o Instituto de Pesquisa Social (Institut fuer Sozialforschung), que inicialmente funcionava na Universidade de Frankfurt, Alemanha. Foi oficialmente criado em 3 de fevereiro de 1923 e seu primeiro diretor foi Carl Grünberg. Horkheimer assumiu a direção Instituto em 1930 e o dirigiu até sua aposentadoria em 1967, quando foi substituído por Adorno. Em 1933, com a chegada de Hitler ao poder, o Instituto foi transladado ao exterior, primeiramente para Genebra, Suíça, e no ano seguinte para Nova York, Estados Unidos, onde passou a funcionar num edifício cedido pela Universidade de Columbia. A Escola de Frankfurt foi também uma "Escola de Nova York", já que nessa cidade as principais obras do grupo foram produzidas, incluindo o mencionado texto que deu origem à teoria crítica. Com o final da Segunda Guerra, em 1950, o Instituto de Pesquisa Social retornou a sua sede original, em Frankfurt, onde funciona desde então. (FREITAG, 2004). 
teórico crítico. Grundy (1994, p. 38), uma educadura crítica, chega até mesmo a afirmar:

En primer lugar, el interés emancipador genera teorías críticas. Son teorías acerca de las personas y sobre la sociedad que explican cómo actúan la restricción y la deformación para inhibir la libertad. La psicología freudiana constituye un ejemplo de teoría crítica sobre la inhibición de la libertad en los individuos; el marxismo es un ejemplo de teoría crítica acerca de la inhibición de la libertad en sociedades enteras, y distintas teorías de la ideología tratan también el problema de cómo la interacción puede resultar deformada o reprimida por determinados intereses. Ciertas ramas de la cristiandad están desarrollando también teorías críticas, por ejemplo, la Teología de la Liberación.

Não abriria tanto assim o leque. Parece-me mais prudente circunscrever a "teoria crítica" ao pensamento neomarxista, como uma corrente de pensamento herdeira do "marxismo de Marx" (ARON, 2005), proposta de seus próprios formuladores.

A teoria crítica, como filosofia e método de abordagem da realidade, é transdisciplinar e interdisciplinar. Isso vem de sua própria origem: o "materialismo interdisciplinar" dos primeiros frankfurtianos (NOBRE, 2004). Inicialmente os pesquisadores da Escola de Frankfurt desenvolviam estudos em diversas disciplinas e se pautavam por uma visão do mundo orientada pelo materialismo histórico e dialético de Marx e Engels, portanto para além da fragmentação cartesianopositivista.

Lefebvre (1991, p. 80) também acreditava na interdisciplinaridade ao afirmar: "A ciência tende, a partir de seu próprio seio, a quebrar os limites fechados e a criar um espírito de equipe.”. Assim é possível estabelecer um paralelo entre o livro Teoria tradicional e teoria crítica, de Horkheimier, e o livro Lógica formal lógica dialética, escrito por Lefebvre em 1946-47, e dizer que a lógica formal está para a teoria tradicional assim como a lógica dialética está para a teoria crítica. Freitag (2004, p. 49) afirma que "a dialética, ao contrário da lógica formal, é capaz de incluir em seus conceitos os elementos da contradição e da transformação, e de abarcar o não-idêntico em um mesmo conceito". Embora muitos possam não concordar, para Lefebvre, não há dúvidas de que a dialética, além de lógica, é também um método: 
Para Aristóteles, a lógica (Organon, Analíticos) é a teoria do Logos em ato: razão e raciocínio, coerência do discurso, linguagem do cidadão que vivia na cidade política, buscando os meios de deduzir para convencer (não para seduzir), meios diferentes da sofística, da erística, da dialética ou arte do diálogo. Mas não absolutamente diferentes. Do que decorre uma ambigüidade que durou séculos. De modo que a filosofia chamou às vezes de "dialética" aquilo que chamamos de "lógica", e viceversa, sem ver na dialética, na lógica, um método. (LEFEBVRE, 1991, p. 6, grifo do autor).

Horkheimer (1980a, p. 133) faz claramente esse paralelo quando afirma: "A suposição da invariabilidade social da relação sujeito, teoria e objeto distingue a concepção cartesiana de qualquer tipo de lógica dialética.”. Para ele, a lógica formal é parte da teoria tradicional e a lógica dialética é constitutiva da teoria crítica. Por ser tributária do pensamento de Marx, essa teoria claramente incorpora a dialética em suas reflexões.

A orientação para a emancipação da classe trabalhadora e o papel do teórico como crítico da realidade e estimulador do processo transformador ficam evidentes no seguinte trecho:

[...] a função da teoria crítica torna-se clara se o teórico e a sua atividade específica são considerados em unidade dinâmica com a classe dominada, de tal modo que a exposição das contradições sociais não seja meramente uma expressão da situação econômica concreta, mas também um fator que estimula e que transforma. (HORKHEIMER, 1980a, p. 136).

Entretanto, parece-me uma postura um tanto elitista, diria até intelectualmente arrogante, que fica mais evidente no trecho a seguir: "Cabe ao teórico introduzir essa tenacidade nos grupos mais avançados das camadas dominadas, pois é justamente dentro dessas camadas que esses grupos se encontram ativos." (HORKHEIMER, 1980a, p. 139). Trata-se da concepção do intelectual orgânico, que Horkheimer, embora sem conhecê-lo, desenvolveu simultaneamente com Antonio Gramsci, teórico marxista italiano, autor do livro Os intelectuais e a organização da cultura (FREITAG, 2004).

$\mathrm{Na}$ área educacional, além dos autores que foram mencionados anteriormente, um dos grandes teóricos críticos foi, sem dúvida, Paulo Freire. Em seu livro Pedagogia do oprimido, escrito no exílio em Santiago (Chile), entre 1967 e 1968, deixa claro o papel emancipador da educação problematizadora, libertadora, 
em contraposição ao que ele chama de educação "bancária", legitimadora da dominação. "Para a educação problematizadora, enquanto um quefazer humanista e libertador, o importante está em que os homens submetidos à dominação lutem por sua emancipação." (FREIRE, 2005, p. 86). Esse ponto de vista é reforçado no livro Pedagogia da esperança, escrito em São Paulo, em 1992, no qual o autor se reencontra com Pedagogia do oprimido, 25 anos depois. Paulo Freire afirma que a esperança é uma necessidade ontológica, mas deve ser crítica e ancorada na prática para se tornar concretude histórica. Enfatizando a Educação como um ato político e práxico, alerta: "Pensar que a esperança sozinha transforma o mundo e atuar movido por tal ingenuidade é um modo excelente de tombar na desesperança, no pessimismo, no fatalismo.". Em seguida, reafirmando seu otimismo de educador crítico e humanista, ressalva: "Mas, prescindir da esperança na luta para melhorar o mundo, como se a luta pudesse reduzir a atos calculados apenas, à pura cientificidade, é frívola ilusão." (FREIRE, 2006, p. 10).

Ao contrário de Horkheimer (1980a), Freire (2005) primava pela humildade intelectual, acreditava que a busca da transformação social e da emancipação era algo a ser construído numa relação dialógica e não "introduzida" pelo teórico (ou professor) nas "massas oprimidas" (e incultas, pode-se inferir da fala de Horkheimer) da sociedade. Sua prática pedagógica sempre levou em consideração o saber, o conhecimento tácito dos "oprimidos"17.

A noção de emancipação - do sujeito envolvido com o objeto que busca transformar, além de vivenciar sua própria autotransformação, deixando evidente a modalidade política da teoria (e também da educação) - pode ser buscada, parafraseando Aron (2005), no "marxismo de Marx" (e também de Engels). O último número do jornal Nova Gazeta Renana, do qual Marx era um dos articulistas, publicado em 19 de maio de 1849, antes de ser fechado pelo governo da Prússia, trouxe uma proclamação de despedida dos redatores endereçada aos operários de Colônia: "a última palavra do jornal será por toda parte e sempre: Emancipação da classe operária!" (MARX, 1978, p. 131, grifo do autor). Essa idéia fica mais

\footnotetext{
17 Freire (2005) ora fala em "oprimidos", ora em "massas", ora em "massas oprimidas".
} 
evidente no Manifesto comunista, panfleto revolucionário lançado no ano anterior (foi publicado pela primeira vez em Londres, em fevereiro de 1848).

Naquele momento, para Marx e Engels, a emancipação, a libertação do proletariado, exigia a revolução social. Passava necessariamente pela tomada do poder político e pela expropriação da propriedade privada, base da exploração da classe operária pelos detentores do capital. Ou seja, exigia a implantação do socialismo. "Em lugar da antiga sociedade burguesa, com suas classes e antagonismos de classes, surge uma associação onde o livre desenvolvimento de cada um é a condição do livre desenvolvimento de todos." (MARX; ENGELS, 1985, p. 38). Para isso, finalizavam seu panfleto conclamando todos os trabalhadores do mundo à ação, já que a revolução socialista - pensavam - necessariamente teria de ser internacional: "Proletários de todos os países, uni-vos!" (MARX; ENGELS, 1985 , p. 55, grifo do autor).

Conforme o modelo crítico desenvolvido na década de 1940, especialmente no livro Dialética do esclarecimento ${ }^{18}$, Horkheimer chega à conclusão de que as possibilidades de esclarecimento e emancipação da classe trabalhadora naquele momento estão completamente bloqueadas. Isso é resultado da consolidação do capitalismo administrado (ou tardio), do surgimento de uma aristocracia operária, da integração das massas à sociedade de consumo e do império da razão instrumental, que perpassa todos os setores da sociedade. A razão instrumental, segundo Horkheimer e Adorno (1985), transformou a razão iluminista em mito e minou seu potencial esclarecedor e emancipador. $O$ bloqueio à emancipação também é resultado da expansão e do fortalecimento dos meios de comunicação e da hegemonia da "indústria cultural". Diante disso, para eles o pensamento esclarecedor (a teoria) passa a ser a única possibilidade de transformação, entretanto admitem estar diante de uma aporia ${ }^{19}$ : "A aporia com que

Esse livro, escrito com Adorno, foi publicado em 1947.

19 Segundo o Houaiss (2008), o vocábulo "aporia" vem do grego "aporía, as 'embaraço, incerteza em uma discussão ou pesquisa', de áporos 'que não tem passagem', daí 'que está embaraçado"”; portanto, trata-se de uma "dificuldade ou dúvida racional decorrente de uma impossibilidade objetiva na obtenção de uma resposta ou conclusão para uma determinada indagação filosófica". Durozoi e Roussel (1996, p. 33) assim definem "aporia": "Em filosofia moderna e principalmente em Kant, o termo é considerado num sentido mais forte para designar uma dificuldade lógica insolúvel.". Para Abbagnano: "Este término ha sido usado en el sentido de duda racional, es decir, de dificultad inherente a un razonamiento, y no de estado subjetivo de incertidumbre. Por lo tanto, es la duda objetiva, la efectiva dificultad de un razonamiento o de la conclusión, 
defrontamos em nosso trabalho revela-se assim como o primeiro objeto a investigar: a autodestruição do esclarecimento." (ADORNO; HORKHEIMER, 1985, p. 13).

Para Habermas $(1993,2003)$, principal herdeiro e continuador da teoria crítica, a aporia com que defrontaram Adorno e Hokheimer (1985) se explica pelo fato de que a visão de emancipação que possuíam ainda se baseava no pensamento de Marx, na noção de revolução sob o comando do proletariado politicamente organizado, enfim, no paradigma da filosofia da consciência. Considerando a análise do momento presente, e nisso Harbermas não discordava da interpretação de Adorno e Horkheimer, a emancipação deveria ser desvinculada da noção marxista de revolução. Deveria ser buscada nos mecanismos de participação próprios do Estado democrático de direito. Indagado sobre que tendências identificava nos processos de emancipação de sua época, assim responde Habermas (1993, p. 101-102):

Eu penso na liberdade individual, na segurança social e na co-gestão política, existentes nas regiões mais mimadas de nosso planeta, que conquistaram para a vida do indivíduo um valor maior, uma maior consideração. Antes da Revolução Francesa, antes dos movimentos dos operários europeus, antes da propagação da escolaridade formal, antes dos movimentos feministas, antes da domesticação das condições violentas no interior das famílias, prisões, hospitais, etc., a vida de uma mulher ou de um homem singular era menos valiosa - naturalmente não na nossa visão, mas na perspectiva dos contemporâneos.

Embora concorde com Habermas que não faz mais sentido a concepção de emancipação do tempo de Marx, não deixa de ser lamentável que só se possa falar em emancipação, sob essa nova perspectiva, para as regiões "mais mimadas" do planeta, entre as quais se encontra a Europa, de onde ele escreve. De fato, nas regiões "menos mimadas" do mundo, como a América Latina, de onde escrevo, apesar do avanço da democracia, a vida de uma pessoa ainda não tem "um valor maior", não tem "uma grande consideração". E a valorização da pessoa humana deve ser o principal fim de qualquer processo emancipatório.

Os atuais partidos de origem operária, como o Partido dos Trabalhadores (PT) e o Partido Socialista Obrero Español (PSOE), ambos no poder, respectivamente, no Brasil e na Espanha, também não acreditam na emancipação 
como pensada nos tempos de Marx. Mesmo no Manifesto de fundação do PT, em 1980, isso já ficava evidente:

O Partido dos Trabalhadores nasce da vontade de independência política dos trabalhadores, já cansados de servir de massa de manobra para os políticos e os partidos comprometidos com a manutenção da atual ordem econômica, social e política. Nasce, portanto, da vontade de emancipação das massas populares. (PT, 1980, grifo nosso).

Porém, essa "independência política", essa "emancipação" dos trabalhadores, não passa pela ruptura da ordem política e econômica, pela revolução socialista (expressão que não aparece em nenhum momento no manifesto). Pressupõe, isto sim, o fortalecimento do Estado democrático de direito, a maior participação dos trabalhadores na tomada de decisões políticas e a melhoria de suas condições de vida, como fica patente pelo trecho a seguir:

Em oposição ao regime atual e ao seu modelo de desenvolvimento, que só beneficia os privilegiados do sistema capitalista, o PT lutará pela extinção de todos os mecanismos ditatoriais que reprimem e ameaçam a maioria da sociedade. O PT lutará por todas as liberdades civis, pelas franquias que garantem, efetivamente, os direitos dos cidadãos e pela democratização da sociedade em todos os níveis. (PT, 1980).

A chegada do PT ao poder, 23 anos depois de seu surgimento, com a eleição de Luiz Inácio Lula da Silva como Presidente da República, só confirma a coerência com os compromissos assumidos no Manifesto de fundação.

$\mathrm{Na}$ Espanha, o $\mathrm{PSOE}^{20}$, ao chegar ao poder com a eleição do primeiroministro Felipe González, em 1982, abriu mão dos compromissos históricos do partido com a revolução socialista e passou a investir na consolidação da democracia parlamentar, no fortalecimento da economia capitalista e na integração européia. Na interpretação de Judt (2008, p. 524-525):

20 É importante notar que o PSOE nasceu socialista. Foi criado em 1879, época em que a revolução socialista era alternativa real posta aos partidos operários. Só muito mais tarde, em outro contexto político e socioeconômico, deixou de apostar na revolução. Já o PT foi criado em 1980, exatamente no momento em que o PSOE estava deixando de ser socialista. De fato, o PT nunca acreditou realmente na revolução socialista. O máximo que prega é a construção do socialismo democrático, como consta no artigo $1^{\circ}$ de seu Estatuto: “O Partido dos Trabalhadores (PT) é uma associação voluntária de cidadãs e cidadãos que se propõem a lutar por democracia, pluralidade, solidariedade, transformações políticas, sociais, institucionais, econômicas, jurídicas e culturais, destinadas a eliminar a exploração, a dominação, a opressão, a desigualdade, a injustiça e a miséria, com o objetivo de construir o socialismo democrático." (PT, 2001). 
As mudanças de rumo não tornaram González benquisto aos socialistas da velha guarda, cujo partido ele agora conduzia para longe do antigo compromisso marxista. [...] Segundo a estimativa de González o futuro da Espanha não estava no socialismo, mas na Europa.

Os acordos sociais, iniciados com os Pactos de Moncloa em 1977, entre o governo, os empresários e os partidos-sindicatos, criaram ao longo dos anos 1980 uma situação de relativa paz social e de melhoria das condições de vida, levando os trabalhadores a abdicar da luta pela revolução socialista. De acordo com García de Cortázar e González Vesga (1994, p. 630-631): “Aparcando sus convicciones ideológicas, la clase obrera, gracias a ellos, aceptó el sistema socioeconómico definido en la Constitución.".

Voltando aos teóricos: a ação instrumental, objeto da crítica de Adorno e Horkheimer, é monológica, orientada ao êxito, à reprodução material da sociedade. Em contraposição a ela, Habermas propõe um novo tipo de racionalidade, a ação comunicativa, dialógica, orientada ao entendimento, à reprodução simbólica da sociedade (FREITAG, 2004; GARCIA, 2005; NOBRE, 2004). A ação comunicativa implica simetria, exige a existência de igualdade entre os interlocutores em um ambiente de liberdade, no qual haja ausência de coerção e predomine o melhor argumento na busca do entendimento. $O$ melhor argumento é aquele que se atinge por meio do diálogo, do discurso, numa relação dialógica baseada na razão comunicativa. Como explica Freitag (2004, p. 59):

A concepção de uma razão comunicativa implica uma mudança radical de paradigma, em que a razão passa a ser implementada socialmente no processo de interação dialógica dos atores envolvidos em uma mesma situação. A razão comunicativa se constitui socialmente nas interações espontâneas, mas adquire maior rigor através do que Habermas chama de discurso. $\mathrm{Na}$ ação comunicativa cada interlocutor suscita uma pretensão de validade quando se refere a fatos, normas e vivências, e existe uma expectativa que seu interlocutor possa, se assim o quiser, contestar essa pretensão de validade de uma maneira fundada (begründet), isto é, com argumentos.

Porém, trata-se de uma situação ideal, que na prática quase nunca ocorre, como diz o próprio Habermas (2003, p. 46, grifo do autor): "Considerada como proceso, se trata de una forma de comunicación infrecuente y rara, por tratarse precisamente de una forma de comunicación que ha de aproximarse suficientemente a condiciones ideales.". É exatamente esse o argumento de 
Habermas: é preciso buscar o ideal para que os elementos bloqueadores da comunicação e, conseqüentemente, da emancipação aflorem. Na leitura de Nobre:

[...] ao orientar sua ação para o entendimento, os sujeitos antecipam necessariamente tais condições ideais, pois sem elas não seria possível uma ação comunicativa; simultaneamente, entretanto, tais condições necessárias não são cumpridas, o que permite, por sua vez, que sejam detectadas todas as distorções da comunicação - aqueles obstáculos que impedem a cada vez a plena realização de uma ação comunicativa. (2004, p. 57, grifo do autor).

Nesse sentido, a ação comunicativa pode ter um importante potencial emancipatório, especialmente para as pessoas habitantes das regiões "menos mimadas" de nosso planeta - parodiando Habermas (1993) ao revés - ao menos por evidenciar os elementos bloqueadores do processo.

Aqui fica mais evidente outro pressuposto da teoria crítica: 0 comportamento crítico. Para Horkheimer (1980a), esse termo indica uma propriedade essencial da teoria dialética da sociedade em movimento. Para esse paradigma teórico, o momento do conhecimento da sociedade já é um momento de ação, o que implica considerar que não pode haver a separação sujeito-objeto. De fato, para a teoria crítica, sujeito e objeto não são separados e se influenciam reciprocamente. Também não é aceita a clivagem teoria-prática: conhecimento é práxis. Conforme palavras de Horkheimer (1980a, p. 145):

O comportamento crítico consciente faz parte do desenvolvimento da sociedade. A construção do desenrolar histórico, como produto necessário de um mecanismo econômico, contém o protesto contra esta ordem inerente ao próprio mecanismo, e, ao mesmo tempo, a idéia de autodeterminação do gênero humano, isto é, a idéia de um estado onde as ações dos homens não partem mais de um mecanismo, mas de suas próprias decisões. O juízo sobre a necessidade da história passada e presente implica na luta para a transformação da necessidade cega em uma necessidade que tenha sentido. $O$ fato de se aceitar um objeto separado da teoria significa falsificar a imagem, e conduz ao quietismo e ao conformismo.

Veja que esse trecho explicita, além do comportamento crítico, outro pressuposto basilar dessa teoria: a orientação para a emancipação, para a transformação social, portanto a negação do conformismo. Isso exige que não haja separação entre o sujeito cognoscente e o sujeito atuante, entre o pensamento e a ação, entre a teoria e a prática, como é característico da teoria tradicional. Essa 
exigência perpassa, além das teorias da Escola de Frankfurt, todo o trabalho de Freire $(2005,2006)$ e aparece também nos escritos de Lefebvre (1991).

Aqui reside a maior crítica à teoria tradicional, na qual prevalecem todas essas dicotomias. Portanto o sujeito não é consciente de sua ação e conseqüentemente não está apto a fazer a análise do momento presente nem a auto-reflexão - outros dois pilares da teoria crítica - e muito menos trabalhar para a transformação da realidade. Como nos alerta Horkheimer (1980a, p. 152): "Ninguém pode colocar-se como sujeito, a não ser como sujeito do instante histórico.”. Seguindo essa tradição de pensamento, Habermas (1994, p. 140) argumenta que não há emancipação - não no sentido da tradição marxista, mas no sentido do agir comunicativo - sem auto-reflexão: "A auto-reflexão está determinada por um interesse emancipatório do conhecimento. As ciências de orientação crítica partilham-no com a filosofia.". Logo em seguida, ao criticar as ciências positivas, completa: "A honra das ciências consiste, pois, em aplicar infalivelmente os seus métodos sem refletir acerca do interesse que guia o conhecimento." (HABERMAS, 1994, p. 145).

Inspirando-se em Sartre, quando este diz que "consciência e mundo se dão ao mesmo tempo", Paulo Freire chama a atenção para o fato de que a educação como prática de liberdade é a negação do homem abstrato, isolado, desligado do mundo, assim como também é a negação do mundo sem homens:

A reflexão que propõe, por ser autêntica, não é sobre este homem abstração nem sobre este mundo sem homens, mas sobre os homens em sua relação com o mundo. Relações em que consciência e mundo se dão simultaneamente. Não há uma consciência antes e um mundo depois e vice-versa. (FREIRE, 2005, p. 81).

Como nos lembra Lefebvre (1991), a vida é movimento e tudo está integrado, ou seja, é dialética. Se o mundo se transforma, a teoria tem que mudar. Daí a importância da análise crítica da época em que vive o teórico e de sua autoreflexão. Ou seja, os pressupostos básicos da teoria crítica são fundamentais para a compreensão do processo educacional no mundo de hoje. Vejamos, então, algumas possibilidades da abordagem crítica em Educação. 


\section{Abordagem crítica em Educação: algumas possibilidades}

$\mathrm{Na}$ época de Teoria tradicional e teoria crítica, Horkheimer, como Marx, ainda acreditava que o sujeito da transformação sociopolítica era o proletariado. Com o passar do tempo, essa crença foi se arrefecendo até mergulhar, com Adorno, num ceticismo aporético na época de Dialética do esclarecimento. Aí reside uma diferença importante em comparação com Freire. Para este educador crítico, porém permanentemente otimista, os sujeitos da transformação libertadora eram os educadores-educandos envolvidos numa relação dialógica. Nessa relação, como proposto por Habermas na ação comunicativa, não pode haver coerção. Nesse sentido, Freire encarava a Educação como uma atividade eminentemente política e com potencial emancipador.

Max Horkheimer (1875-1973) e Theodor Adorno (1903-1969) escreveram nas décadas de 1930-40, Paulo Freire (1921-1997) lançou Pedagogia do oprimido no final dos anos 1960. Acreditavam aqueles (apesar do ceticismo tardio dos frankfurtianos) na revolução social, na emancipação da "classe dominada"; este, na emancipação das "massas oprimidas".

Agora, uma questão crucial que se coloca é: o que vem a ser emancipação hoje? Para tentar responder a essa questão sendo coerente com a teoria crítica, com a análise do momento presente, é preciso considerar as transformações políticas, socioeconômicas, culturais e tecnológicas que estão ocorrendo no mundo e no interior de cada uma das formações socioespaciais.

Algumas páginas atrás, dissemos que Habermas, tentando resolver a aporia em que estavam metidos os fundadores da teoria crítica, indicou algumas possibilidades do que seria emancipação nos dias de hoje. Associou-a claramente à valorização da vida em um Estado democrático de direito, ao restabelecimento do vínculo entre o Estado e o mundo vivido, à valorização do espaço público. Freitag, falando sobre a crise do Estado capitalista contemporâneo aponta dois caminhos: um para frente, o socialismo, outro para trás, o fascismo, que, como vimos, já tiveram formas históricas concretas, e um terceiro, vislumbrado por Habermas: 
Habermas busca um terceiro caminho, qual seja, reinscrever o Estado na modalidade de Lebenswelt [mundo vivido]. Isso significa inseri-lo novamente naquele quadro institucional em que a política deixa de ser uma simples técnica de silenciamento, uma forma de manifestação da racionalidade instrumental, que despolitizara os assuntos de Estado, voltando a ser a polis, ou seja, aquele locus da vida societária em que as grandes decisões são tomadas como um todo, à base do discurso teórico e prático. $\mathrm{O}$ Estado voltaria a ser, como na Grécia antiga, um espaço da Lebenswelt com a integração social assegurada e não um subsistema cooptado ao sistema econômico, regido pelo princípio da acumulação ampliada. (FREITAG, 2004, p. 103-104).

Ao analisar o tempo presente, a realidade atual, é inevitável concluir que essa proposta tem uma elevada dose de utopia, que, entretanto, é necessária para nos fazer avançar, para movimentar o motor da história.

Considerando que o mundo é movimento, que é dialético, e sendo coerente com a teoria crítica, não é tarefa fácil definir categoricamente o que é emancipação hoje, mas é possível fazer algumas aproximações. Certamente não passa, ao menos no presente e num futuro que se possa vislumbrar, pela revolução social como imaginada por Marx e Engels, por Horkheimer e Adorno (apesar do ceticismo tardio) e mesmo por Freire, no livro Pedagogia do oprimido. Alguns caminhos foram apontados por Habermas, como a ação comunicativa e a valorização do mundo vivido, e talvez Freire tenha sido quem melhor conseguiu operacionalizá-la no campo educacional, com sua proposta de educação dialógica, especialmente no livro Pedagogia da esperança.

Conseqüentemente, outra questão sobre a qual é fundamental refletir é a seguinte: a emancipação é uma conquista coletiva ou individual?

Em sua gênese marxista, como vimos, a emancipação era claramente um projeto coletivo associado a uma classe social, o proletariado. Nos primórdios da teoria crítica, continuou sendo um projeto coletivo para o qual o teórico, em unidade dinâmica com a classe dominada, deveria contribuir. Grundy (1994), seguindo essa tradição, acredita que o interesse emancipador está voltado para a emancipação como realidade social, como conquista coletiva. E mais, para essa pesquisadora, a idéia de emancipação individual está associada ao liberalismo:

[...] aunque éste ofrezca a los niños individuales de la clase trabajadora la posibilidad de escapar de la opresión a través de la movilidad social ascendente, esa 
emancipación individual depende de la persistencia de las relaciones sociales desiguales para la mayoría de la clase trabajadora. (GRUNDY, 1994, p. 159)

Por mais que Grundy tenha se inspirado em Habermas, em quem buscou a teoria dos interesses cognitivos (ver quadro 1) para embasar sua discussão sobre currículo, ele pensa de forma diametralmente oposta. O filósofo alemão crê que a emancipação é uma conquista do sujeito, portanto, da pessoa ${ }^{21}$ (coerentemente, ele não usa indivíduo), em seu processo de auto-reflexão, de autocompreensão, de transformação. Em seguida acrescenta:

Entretanto, quando alguém pretende retraduzir essa expressão para o domínio social do qual ela originariamente descende - enquanto expressão jurídica "emancipação" significa a libertação de escravos ou o momento em que a criança passava para a fase adulta - é preciso precaver-se para não recobrir as condições sociais com conceitos de uma filosofia do sujeito, que não servem para aquelas. Não se pode representar os coletivos sociais, nem as sociedades em sentido global, como se fossem sujeitos em tamanho grande. Essa é a razão que me leva a ser muito cauteloso quanto ao emprego da expressão "emancipação" fora do contexto das experiências autobiográficas. (HABERMAS, 1993, p. 100).

Por isso Habermas tem preferido usar, em lugar de "emancipação", os conceitos de "entendimento" e "ação comunicativa" para apreender as relações sociais intersubjetivas.

No "marxismo de Marx" (ARON, 2005), como vimos, a idéia de emancipação tinha uma conotação econômica - estava atrelada à categoria trabalho - e, claro, também política. Sua conquista estava associada a uma classe social consciente, politicamente organizada, que transformaria as relações de propriedade. Portanto, era um projeto eminentemente coletivo e, mais, revolucionário. Embora tenha criticado as limitações do liberalismo para promover a emancipação, Grundy (1994) também pensou esse conceito do ponto de vista econômico, quando o associou à idéia de mobilidade social.

$21 \quad$ Machado (2002) diz que o conceito de pessoa transcende as noções de individuo e mesmo de cidadão. Pessoa, desde sua etimologia latina persona (máscara que os atores usavam no teatro), está associada à idéia de representação de papéis sociais. Uma pessoa é, antes de tudo, um indivíduo (do latim individuum, "que não se divide") e pode ou não ser um cidadão, mas representa outros papéis sociais na família, no trabalho, no clube, na igreja, no bairro, no município etc. Enfim, pessoa é um conceito mais abrangente e indivíduo acabou empobrecido por sua associação com o liberalismo, de onde ganhou derivações pejorativas, como individualismo e individualista. 
A discussão sobre o significado de emancipação não é trivial e muitos autores a evitam, mesmo quando utilizam o termo. Castellar (2003, p. 113), por exemplo, falando sobre a formação docente, afirma:

O professor deve, portanto, atuar no sentido de se apropriar de sua experiência, do conhecimento que tem para investir em sua emancipação e em seu desenvolvimento profissional, atuando efetivamente no desenvolvimento curricular, deixando de ser um mero consumidor de informação genérica.

Esse trecho é reproduzido no documento Orientações Curriculares para o Ensino Médio (BRASIL, 2006, p. 46), do qual Castellar é uma das autoras, porém nem no artigo nem na proposta curricular do MEC há uma explanação sobre o significado de emancipação. O que isso quer dizer? Como o professor poderá "investir em sua emancipação"? Também chama atenção o fato de que as Orientações Curriculares falam em emancipação do professor, mas não do aluno.

O filósofo Marcos Nobre, no debate que se seguiu à conferência Max Horkheimer: a teoria crítica entre o nazismo e o capitalismo tardio, ministrada no Curso livre de teoria crítica ${ }^{22}$, ao meu questionamento sobre qual seria o significado de emancipação hoje, esquivou-se de uma definição fechada. Afirmou que não saberia responder e que, sendo coerente com a teoria crítica, essa definição deveria ser construída no processo sócio-histórico, na luta política do momento atual. No texto de dezoito páginas publicado no livro Curso livre de teoria crítica, no qual reuniu os artigos de todos os conferencistas daquele evento, Nobre (2008) utiliza vinte vezes a palavra emancipação e variantes como "emancipada" (duas vezes, referindo-se à sociedade), "possibilidade emancipatória" e "sentido emancipatório". Coerente com seu discurso, não arrisca uma definição, mas dá vários indícios. Em pelo menos cinco passagens fala em "emancipação da dominação", às vezes acompanhada de "vigente" e "capitalista". Donde se conclui que, em sua leitura de Horkheimer, a emancipação passa pela libertação da dominação capitalista, pela transformação da sociedade. Isso fica mais evidente no seguinte trecho, quando, após denunciar as parcialidades da ciência "objetiva", pretensamente neutra, afirma que a atitude crítica "não se volta apenas para o conhecimento, mas para a própria

22 Palestra realizada no Goethe-Institut São Paulo, em 25 de setembro de 2006, durante o Curso livre de teoria crítica, realizado de 11 de setembro a 27 de novembro de 2006. 
realidade das condições sociais capitalistas, e isso porque o comportamento crítico tem sua fonte na orientação para a emancipação relativamente à dominação vigente". (NOBRE, 2008, p. 45, grifo do autor). Entretanto, não deixa de lembrar que Horkheimer e Adorno não acreditavam mais no proletariado como sujeito desse processo. Quem seria, então, o sujeito responsável pela emancipação da dominação vigente?

Emancipação não é uma noção filosófica, nem mesmo sociológica. Os dicionários dessas disciplinas não a registram; sua origem deve ser buscada no campo jurídico. Como lembra o próprio Habermas (1993, p. 100), citado alguns parágrafos atrás, "enquanto expressão jurídica 'emancipação' significa a libertação de escravos ou o momento em que a criança passava para a fase adulta". De fato, se consultarmos um dicionário comum, como o Michaelis (1998, p. 776), veremos que emancipação significa: "1. Ato ou efeito de emancipar ou de se emancipar. 2. Dir Aquisição da capacidade civil antes da idade legal. 3. Alforria ${ }^{23}$, libertação". Em espanhol esse vocábulo apresenta os mesmos significados. No dicionário da Real Academia Española (2008) só consta a primeira acepção para o substantivo: "Emancipación 1. Acción y efecto de emancipar o emanciparse." Mas quando define o verbo, as outras acepções ficam evidentes: "Emancipar 1. Libertar de la patria potestad, de la tutela o de la servidumbre.".

Silva (2004, p. 511), em seu Vocabulário jurídico, define emancipação como consta abaixo, para em seguida listar as situações em que pode ser concedida ao menor de idade, de acordo com o Código Civil Brasileiro de 2002:

Derivado do latim emancipatio, de emancipare (emancipar), tinha primitivamente o sentido de livre alienação de bens, significando ainda dom ou dádiva da liberdade. Mas, porque pela emancipação o filho-família (menor) fosse autorizado a vender ou dispor livremente de seus bens, veio a designar o próprio ato de liberdade paterna/materna, de liberdade legal ou concessão judicial, em virtude do qual se antecipa a maioridade de uma pessoa, atribuindo-Ihe plena capacidade jurídica para gerir seus negócios e dispor de seus bens.

Assim, em sua origem jurídica, a emancipação era concedida no passado por alguém que detinha a propriedade de uma pessoa, no caso do senhor de

23 O substantivo "alforria" vem do árabe al-hurryah, "liberdade concedida ao escravo" (MICHAELIS, 1998, p. 103). 
escravo, ou a tutela (ou pátrio poder) sobre alguém, no caso dos responsáveis por um menor de idade. O escravo emancipado, alforriado, ganhava a liberdade sobre seu próprio corpo, tornando-se senhor de si, e o direito e ir e vir. O menor de idade emancipado se livrava da tutela familiar e ganhava plenos direitos civis, tornando-se responsável legal por si próprio. Por extensão, o termo "emancipação"24 passou a ser utilizado como sinônimo de libertação de qualquer tipo de tutela, de jugo, de controle.

Pensar a emancipação apenas do ponto de vista econômico e associá-la a uma classe social em particular de fato parece-me limitante e não coaduna com a realidade do momento atual. Embora acredite com Habermas que a emancipação é uma conquista do sujeito, da pessoa, não vejo incompatibilidade com a possibilidade de uma emancipação coletiva, de um grupo social maior, de uma comunidade, afinal coletividades são feitas de pessoas. De qualquer forma, trata-se de uma conquista pessoal mesmo que inserida num projeto coletivo. Digo mais: ainda que uma coletividade possa conquistar a emancipação, nada garante que isso será logrado por todos os seus membros, porque, como afirma Habermas (1993, p. 99):

Emancipação tem a ver com libertação em relação a parcialidades que, pelo fato de não resultarem da causalidade da natureza ou das limitações do próprio entendimento, derivam, de certa forma, de nossa responsabilidade, mesmo que tenhamos "caído" nelas por pura ilusão. A emancipação é um tipo especial de auto-experiência porque nela os processos de auto-entendimento se entrecruzam com um ganho de autonomia.

Interessante perceber que, em sua origem jurídica, a emancipação é quase sempre concedida por alguém que detém a propriedade ou a tutela. No sentido mais amplo, como utilizado pelos teóricos críticos desde Marx e que utilizaremos aqui, a emancipação deve ser conquistada.

Além de todos esses argumentos, defendo que a abordagem críticodialética $^{25}$ é mais indicada para o desenvolvimento de uma pesquisa na área educacional porque:

24 O verbo "emancipar" vem do latim emancipare, "pôr fora de tutela" (HOUAISS, 2008).

25 Agora já possível fazer essa afirmação: falar em abordagem crítico-dialética a rigor implica uma redundância, pois, como vimos, toda a abordagem crítica, tributária da teoria crítica, necessariamente é dialética. Como diz Horkheimer (1879, p, 160): "A teoria dialética não faz a sua crítica a partir da mera idéia.". 
- A Educação é uma atividade ancorada na ação e na reflexão, na teoria e na prática, ou seja, na práxis; tem na relação teoria-prática uma de suas dimensões mais importantes. É um "quefazer" e, como nos ensinou Freire (2005, p. 141), "todo fazer do quefazer tem de ter uma teoria que necessariamente o ilumine. O quefazer é teoria e prática. É reflexão e ação.". Espero estabelecer essa ligação teoria-prática.

- O currículo (e, portanto, a Educação) não é neutro, reflete o conflito de interesses existente na sociedade e os valores dominantes que regem os processos educativos. Espero desvendar esse conflito expresso nos documentos governamentais do Ministério da Educação (Brasil) e do Ministério de Educación y Ciencia (Espanha).

- A Educação, que se materializa por meio do currículo, que, por sua vez, expressa uma seleção de conteúdos culturais a serem ensinados na escola, chamada por Apple (2006) de "tradição seletiva", é uma práxis, ou seja, é uma ação com intencionalidade mediada pela teoria. Procurarei explicitar essa seletividade e essa intencionalidade.

- A Educação é uma relação dialética cultura-currículo, escolasociedade, e vem sendo instrumentalizada pelos interesses econômicos dominantes na sociedade e mais ainda pelas recentes reformas educacionais, que procuram adaptar a escola às novas demandas do sistema produtivo, da chamada sociedade do conhecimento. Buscarei desvendar as contradições e os conflitos de interesse existentes nessas relações, especialmente a contradição entre 0 potencial emancipador da Educação e a hegemonia do interesse técnico que orienta as reformas (ver quadro 1). Como propõe Lefebvre (1991, p. 192), como uma regra do método: "Para determinar o concreto, descubra as contradições.". Para ele a contradição dialética é um sintoma da realidade.

- A Educação, especialmente por meio do currículo, tem um caráter ideológico, no sentido de que, muitas vezes, cria e sustenta relações de dominação. Espero identificar alguns dos modus operandi da ideologia, segundo Thompson (2000), nas propostas de reforma educacional para o ensino médio, tanto no Brasil como na Espanha. 
Adorno (2003, p. 141), ao tentar definir sua concepção de Educação no texto Educação - para quê? rechaça-a como modelagem de pessoas e também como mera transmissão de conhecimentos, afirmando que seu papel é a "produção de uma consciência verdadeira". Maar (2003, p. 61) é peremptório ao interpretar, que com esta frase Adorno: "Pensava, obviamente, na 'falsa consciência', vinculando educação e crítica à ideologia e, portanto, educação à Política.". De fato, Adorno (2003, p. 141-142) destaca o papel político e emancipador da Educação e sugere o que pode ser considerado emancipação nas sociedades democráticas ao afirmar que "uma democracia com o dever de não apenas funcionar, mas operar conforme seu conceito, demanda pessoas emancipadas. Uma democracia efetiva só pode ser imaginada enquanto uma sociedade de quem é emancipado.". Com isso fica claro o papel esclarecedor, desalienador da Educação.

Nesse sentido não se deve buscar na teoria crítica uma proposta pedagógica ou uma teoria cognitiva, mas uma orientação de método de abordagem em Educação que resgate sua dimensão política, sua dimensão esclarecedora, visando à emancipação dos sujeitos envolvidos na relação ensino-aprendizagem e ao conseqüente aprofundamento da democracia.

Entretanto, é possível fazer uma aproximação da teoria dos interesses constitutivos do conhecimento (ver quadro 1), proposta por Habermas (1994), um dos herdeiros e atualizadores da teoria crítica, com uma discussão educacional mais específica, diria mesmo com seu nó górdio: o currículo.

Quando Habermas desenvolveu seus estudos sobre a natureza do conhecimento humano, sobre as relações teoria-prática e os interesses cognitivos, não o fez diretamente a partir de considerações pedagógicas. No entanto, com base em seus estudos é possível fazer conexões com a Educação que podem contribuir para a compreensão das práticas pedagógicas (GRUNDY, 1994). O quadro 1 procura fazer uma síntese das conexões dos interesses cognitivos com a Educação ou, mais especificamente, com seu aspecto curricular.

Quadro 1. Interesses constitutivos do conhecimento e currículo

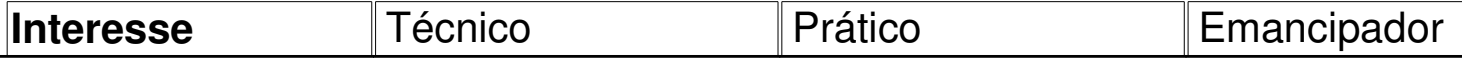




\begin{tabular}{|c|c|c|c|}
\hline \multicolumn{4}{|l|}{ cognitivo: } \\
\hline $\begin{array}{l}\text { Ciência } \\
\text { (método): }\end{array}$ & $\begin{array}{l}\text { Empírico-analítica } \\
\text { (hipotético-dedutivo) }\end{array}$ & \begin{tabular}{|l} 
Histórico- \\
hermenêutica \\
(interpretativo)
\end{tabular} & $\begin{array}{l}\text { Crítica } \\
\text { (dialético) }\end{array}$ \\
\hline Ação: & $\begin{array}{l}\text { Instrumental } \\
\text { (objetiva) }\end{array}$ & $\begin{array}{l}\text { Interativa / prática } \\
\text { (subjetiva) }\end{array}$ & $\begin{array}{l}\text { Comunicativa / } \\
\text { práxica (dialógica) }\end{array}$ \\
\hline Intenção: & Controle & Consenso & Autonomia \\
\hline Orientação para: & Êxito & Compreensão & Emancipação \\
\hline $\begin{array}{l}\text { Resultado da } \\
\text { aprendizagem: }\end{array}$ & Produto & Significados & Consciência crítica \\
\hline $\begin{array}{l}\text { Organização } \\
\text { curricular com } \\
\text { base em: }\end{array}$ & $\begin{array}{l}\text { Objetivos e } \\
\text { resultados (fim) }\end{array}$ & Processos (meio) & $\begin{array}{l}\text { Negociação e } \\
\text { colocação de } \\
\text { problemas (começo) }\end{array}$ \\
\hline
\end{tabular}

Fonte: Organizado pelo autor com base em Grundy (1994) e Habermas (1994).

Deve ser lembrado ainda que, além do currículo escrito, prescrito, orientado por um interesse cognitivo, quase sempre técnico, e atravessado pelos interesses contraditórios e pelos conflitos ideológicos da sociedade que o gestou, há também um currículo oculto, o qual talvez seja ainda mais permeado pela ideologia dominante nessa sociedade. Apple (2006, p. 47), ao refletir sobre como a ideologia permeia a escola, questiona:

Como, concretamente, o conhecimento oficial representa as configurações ideológicas dos interesses dominantes de uma sociedade? Como as escolas legitimam esses padrões limitados e parciais de saber como verdades intocáveis?

Para responder a essas questões, propõe que se examine como as normas diárias da escola contribuem para que os alunos incorporem essas ideologias, como as formas específicas do conhecimento curricular no passado e no presente refletem essas configurações e, finalmente, como essas ideologias se refletem nas perspectivas que os professores empregam para ordenar, orientar e dar significado a seu trabalho docente. Depois disso acrescenta:

A primeira dessas questões refere-se ao currículo oculto das escolas - o ensino tácito de normas, valores e inclinações aos alunos, ensino que permanece pelos simples fato de os alunos viverem e lidarem com as experiências institucionais e rotinas das escolas todos os dias durantes vários anos. (APPLE, 2006, p. 48). 
O currículo oculto não é objeto desta pesquisa (vou me ater ao escrito), entretanto é responsável pela disseminação da ideologia dominante numa determinada sociedade tanto ou mais que o currículo manifesto.

Mas o que é exatamente ideologia? Pode-se falar em ideologia dominante? O conceito de ideologia, por todo seu peso histórico, é um dos que apresentam definição mais complexa.

\section{Tópicos sobre ideologia e cultura}

Para trabalhar com paradigma crítico-dialético em Educação, inevitavelmente é preciso operar com os conceitos de ideologia e cultura. Como nos sugere Apple (2006, p. 36):

[...] devemos complementar a análise de cunho econômico com uma abordagem que se incline mais fortemente a uma orientação cultural e ideológica, a fim de entendermos completamente as complexas maneiras pelas quais as tensões e contradições sociais, econômicas e políticas são "mediadas" nas práticas concretas dos educadores.

A definição do conceito de ideologia, entretanto, não é trivial. Na tentativa de esclarecê-lo, Terry Eagleton listou dezesseis definições em seu livro Ideologia: uma introdução. No entanto, a que tem maior circulação, devido à influência do marxismo, é ideologia como falsa consciência na busca de legitimar a dominação. A quarta definição de sua lista é exatamente "idéias falsas que ajudam a legitimar um poder político dominante." (EAGLETON, 1997, p. 15). O próprio Apple (2006, p. 53-54), em seu livro Ideologia e currículo, afirma que: "Funcionalmente, a ideologia foi avaliada historicamente como uma forma de falsa consciência que distorce o quadro que temos da realidade social e serve aos interesses da classe dominante de uma sociedade.". Embora muito disseminada, esta não é a melhor definição porque é intelectualmente pretensiosa. Para definir ideologia como falsa consciência, como idéias falsas, é necessário que o sujeito se coloque externamente ao objeto e tenha absoluta certeza de que sua consciência, de que suas idéias, são as verdadeiras. Ideologia, assim, é sempre o pensamento do outro. Essa 
exterioridade do sujeito é tudo o que a teoria crítica condena, e essa postura não tem nada de auto-reflexiva nem de dialética. Por isso, numa abordagem crítica, é melhor definir ideologia, conforme faz Thompson (2000), como um embate comunicacional, como uma busca de atribuição de sentido a formas simbólicas na criação e sustentação de relações de poder no interior de cada sociedade. O que Thompson (2000) chama de formas simbólicas são ações e falas, imagens e textos, produzidos por sujeitos e reconhecidos por eles e por outros como construções contextualizadas e significativas.

John Thompson critica a tradição marxista, dominante na conceituação de ideologia. Para ele, essa tradição interpreta a ideologia como uma simples ilusão, como uma imagem invertida e distorcida do que é "real", como idéias ou imagens que refletem de forma inadequada a realidade social que existe antes e independentemente dessas idéias ou imagens. Em seguida propõe que:

As formas simbólicas através das quais nós nos expressamos e entendemos os outros não constituem um outro mundo, etéreo, que se coloca em oposição ao que é real: ao contrário, elas são parcialmente constitutivas do que em nossas sociedades é 'real'. Concentrando o estudo da ideologia no terreno das formas simbólicas contextualizadas, para as maneiras como as formas simbólicas são usadas para estabelecer e sustentar relações de poder, estamos estudando um aspecto da vida social que é tão real como qualquer outro. Pois a vida social é, até certo ponto, um campo de contestação em que a luta se trava tanto através de palavras e símbolos como pelo uso da força física. Ideologia, no sentido que eu proponho e discuto aqui, é uma parte integrante dessa luta; é uma característica criativa e constitutiva da vida social que é sustentada e reproduzida, contestada e transformada, através de ações e interações, as quais incluem a troca contínua de formas simbólicas. (THOMPSON, 2000 , p. 19).

Apple (2006, p. 54), na seqüência da frase citada acima, também incorpora esse ponto de vista quando afirma que a ideologia "também foi tratada, como afirma Geertz, como 'sistemas de símbolos que interagem' e oferecem as principais maneiras de tornar 'significativas situações sociais antes incompreensíveis'.". Em seguida afirma que a ideologia tem três características distintivas: legitimação, conflito de poder e estilo de argumentação. Assim, a ideologia, qualquer que seja ela, é uma tentativa de legitimar a ação de um grupo e sua aceitação social; expressa o conflito entre pessoas e setores sociais que 
buscam ou detêm o poder, e, como estilo de argumentação, no plano da retórica, busca persuadir, mobilizar apoios e converter pessoas para um causa.

Interpretando ideologia como legitimação de ações coletivas, assim a define Habermas (1994, p. 140):

A partir das experiências do dia-a-dia, sabemos que as idéias servem muitas vezes bastante bem para mascarar com pretextos legitimadores os motivos reais das nossas ações. O que a este nível se chama racionalização chamamos-lhe, no plano da ação coletiva, ideologia.

Thompson (2000), por sua vez, aprofunda essa discussão e propõe cinco modos gerais de operação da ideologia com algumas de suas respectivas estratégias de construção simbólica, como mostra o quadro 2. Entretanto, chama a atenção para o fato de que esses cinco modus operandi, além de não serem as únicas maneiras pelas quais a ideologia pode operar, não operam independentemente um do outro, mas, muitas vezes, se sobrepõem ou se reforçam mutuamente. Lembra também que a ideologia pode operar de outras maneiras em determinadas circunstâncias e que as estratégias de construção simbólica não estão necessariamente, mas tipicamente associadas a cada um desses modos gerais de operação. Ressalva que seu objetivo é exemplificar e não fazer uma categorização exaustiva. Finalmente, alerta para o fato de que as estratégicas de construção simbólica não são intrinsecamente ideológicas, mas dependem da forma como são usadas para criar e manter relações de dominação.

\begin{tabular}{|l|l|}
\hline \multicolumn{2}{|l|}{ Quadro 2. Modos de operação da ideologia } \\
\hline Modos gerais & $\begin{array}{l}\text { Estratégias típicas de } \\
\text { construção simbólica }\end{array}$ \\
\hline Legitimação & $\begin{array}{l}\text { - Racionalização } \\
\text { - Universalização } \\
\text { - Narrativização }\end{array}$ \\
\hline Dissimulação & $\begin{array}{l}\text { Deslocamento } \\
\text { - Eufemização } \\
\text { - Tropo* }\end{array}$ \\
\hline Unificação & $\begin{array}{l}\text { - Padronização } \\
\text { - Simbolização da unidade }\end{array}$ \\
\hline Fragmentação & $\begin{array}{l}\text { - Diferenciação } \\
\text { - Expurgo do outro }\end{array}$ \\
\hline
\end{tabular}




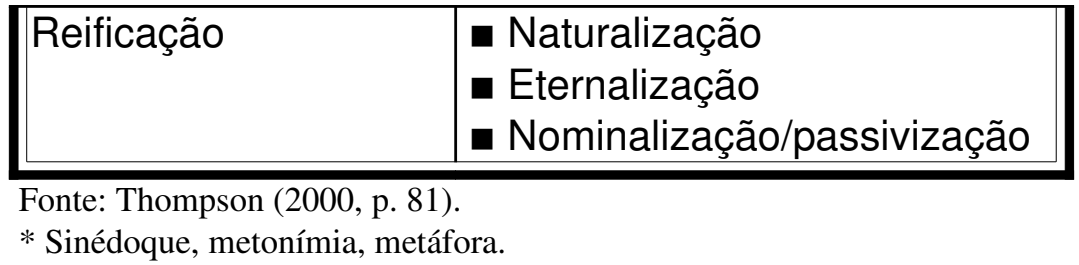

Gostaria de descrever, com base em Thompson (2000), somente os modos gerais de operação da ideologia mais presentes nos textos legais das reformas educacionais e nos documentos curriculares. Nos capítulos em que analisarei as reformas e os currículos de Brasil e Espanha, serão apontadas várias passagens em que aparecem. Os modus operandi da ideologia mais comuns nas leis e nos documentos e suas respectivas estratégias de construção simbólicas são a legitimação (racionalização e universalização), a dissimulação (deslocamento e eufemização) e a reificação (nominalização e passivização).

A legitimação consiste em representar relações de dominação como se, com o perdão da tautologia, fossem legítimas, isto é, como se fossem justas e dignas de apoio. Para isso pode-se lançar mão da estratégia da racionalização. Por meio dela o produtor de uma determinada forma simbólica elabora uma linha de argumentação que busca defender ou justificar um conjunto de relações ou instituições sociais para convencer uma audiência de que ele é digno de apoio. Outra estratégia típica da legitimação é a universalização, por meio da qual acordos sociais, medidas institucionais que servem aos interesses de alguns indivíduos ou grupos em particular, são apresentados como servindo aos interesses de toda a sociedade.

No modo dissimulação, relações de dominação podem ser criadas ou mantidas pelo fato de serem ocultadas, negadas ou obscurecidas ou por serem representadas de forma que desviam a atenção ou passam por cima de relações e processos existentes. Para a operacionalização da ideologia como dissimulação há certas estratégias, entre as quais o deslocamento. Nesse caso um termo em geral usado para se referir a determinado objeto ou pessoa é utilizado para se referir a outro, e as conotações positivas ou negativas desse termo são transferidas para o outro objeto ou pessoa. Outra estratégia muito usada para dissimulação de relações sociais é a eufemização. Caracteriza-se por substituir termos negativos por outros 
que atribuem valoração positiva à descrição de fatos, ações, instituições ou relações.

A reificação como um modus operandi da ideologia consiste na criação ou manutenção de relações de dominação por meio de duas estratégias que se complementam: a naturalização e a eternalização. Nesses casos, ocorre a retratação de uma situação transitória, histórica, como se fosse permanente, ahistórica. Há uma naturalização da História e processos são retratados como coisas, ofuscando seu caráter social e histórico. As estratégias de operacionalização da ideologia como reificação mais visíveis nos documentos das reformas são a nominalização e a passivização. De acordo com Thompson (2000, p. 88):

A nominalização acontece quando sentenças, ou parte delas, descrições da ação e dos participantes nelas envolvidos, são transformadas em nomes, como quando nós falamos em "o banimento das importações, ao invés de [sic] "o Primeiro-Ministro decidiu banir as importações". A passivização se dá quando verbos são colocados na voz passiva, como quando dizemos que "o suspeito está sendo investigado", ao invés de [sic] "os policiais estão investigando o suspeito". A nominalização e a passivização concentram a atenção do ouvinte ou leitor em certos temas com prejuízo de outros.

Tanto uma quanto outra dessas duas estratégias coisificam processos ou acontecimentos, ofuscando ou eliminando o sujeito e a ação. Com isso tais processos ou acontecimentos aparecem naturalizados, como coisas, como se não houvesse responsáveis por eles.

Também é importante levar em conta nesta discussão o conceito de cultura, já que o currículo é uma seleção cultural e a Educação é uma relação escola-sociedade ou escola-cultura. Para Johnson (1997, p. 59): "Cultura é o conjunto acumulado de símbolos, idéias e produtos materiais associados a um sistema social, seja ele uma sociedade inteira ou uma família.”. Thompson (2000) também tem a contribuir nessa discussão. Depois de fazer uma genealogia do conceito de cultura e criticar o que chama de "concepção descritiva", a cientificização do conceito, a partir de Tylor e Malinowski, define o que chama de “concepção simbólica”:

[...] cultura é o padrão de significados incorporados nas formas simbólicas, que inclui ações, manifestações verbais e objetos significativos de vários tipos, em virtude dos 
quais os indivíduos comunicam-se entre si e partilham suas experiências, concepções e crenças. (THOMPSON, 2000, p. 176).

A definição de cultura no plano simbólico, no plano das idéias, da comunicação, é mais adequada para a discussão de seu papel na área educacional, para o qual nos chamam a atenção teóricos críticos da área, como Apple (2006) e Gimeno Sacristán (2000).

É importante também considerar que vivemos em um mundo no qual a cultura foi instrumentalizada, assim como o sistema educacional, pelos interesses do capital. Portanto, torna-se fundamental recuperar os conceitos de "indústria cultural" e de "razão instrumental", desenvolvidos pelos frankfurtianos.

O conceito de "indústria cultural" foi lançado por Adorno e Horkheimer no livro Dialética do esclarecimento, lançado em 1947. O termo busca apreender o fato de que as mídias seguem um modelo, um padrão de produção, tornando-se um negócio. A arte e o lazer passam por um processo de racionalização e se transformam em mercadorias, em bens de consumo. Para eles, com o advento da "indústria cultural", o detalhe técnico se sobrepõe à idéia, à obra: "A indústria cultural desenvolveu-se com o predomínio que o efeito, a performance tangível e o detalhe técnico alcançaram sobre a obra, que era outrora o veículo da Idéia e com essa foi liquidada." (ADORNO; HORKHEIMER, 1985, p. 118, grifo do autor). Além disso, atinge o mundo inteiro, é muito mais penetrante que formas de produção cultural precedentes, impedindo as pessoas de pensar de forma autônoma. Adorno e Horkheimer $(1985$, p. 114) denunciam veementemente o caráter ideológico da "indústria cultural", como fica evidente no trecho a seguir, em que falam do rádio e do cinema: "A verdade é que não passam de um negócio, eles [os dirigentes] a utilizam como uma ideologia destinada a legitimar o lixo que propositalmente produzem.". O que diriam, então, da televisão no mundo de hoje?

Afirmavam, naquela época, que as possibilidades de emancipação estavam bloqueadas, entre outros fatores, pela emergência da "indústria cultural" e pela disseminação da racionalidade técnica. "A racionalidade técnica hoje é a racionalidade da própria dominação." (ADORNO; HORKHEIMER, 1985, p. 114). Se isso era verdadeiro para a época em que escreveram (década de 1940), imagine 
hoje em tempos de globalização, quando o poder da mídia cresceu exponencialmente e a instrumentalização em grau ampliado atingiu todos os setores das sociedades em rede.

Habermas, citando Marcuse, diz que a "razão técnica" transformou-se em ideologia, no sentido de legitimar a dominação: "O conceito de razão técnica é talvez também em si mesmo ideologia. Não só a sua aplicação, mas já a própria técnica é dominação metódica, científica, calculada e calculante (sobre a natureza e sobre o homem)." (MARCUSE, 1965 apud HABERMAS, 1994, p. 46). Como se vê, Habermas, o mais novo dos frankfurtianos, apenas seguiu a trilha aberta por Adorno e Horkheimer. Entretanto, como vimos, Habermas abre uma janela para a busca da emancipação dentro de uma nova perspectiva, ao propor a noção de razão comunicativa, que pode contribuir para impor freios à razão instrumental.

Antes de avançar essa discussão, antes de partir para a análise dos documentos das reformas educacionais no Brasil e na Espanha, são importantes algumas palavras sobre o método de procedimento desta pesquisa.

\section{Método de procedimento}

Como técnica de pesquisa, defini um corpus dos documentos - leis, decretos, pareceres, diretrizes etc. - produzidos pelo Ministério da Educação (MEC), do Brasil, e pelo Ministério de Educación y Ciencia (MEC), da Espanha, a serem analisados (ver lista a seguir). Depois de definir esse corpus, passei a fazer, num trabalho de hermenêutica, uma leitura dos textos legais, buscando interpretá-los para apreender a relação dialética existente nos pares cultura-currículo, escolasociedade e teoria-prática. Nessa leitura interpretativa, à luz do método de abordagem crítico-dialético, busquei desvendar as contradições políticas, as opções teórico-metodológicas e suas eventuais incoerências, os possíveis conflitos de interesses e os pontos de vista ideológicos antagônicos. Evidentemente, contrastei pontos de vista de diferentes autores sobre os mesmos documentos. 
Procurei também mapear nos textos os conceitos e as categorias com os quais teria de trabalhar para dar conta do objeto da pesquisa. Evidentemente que fiz essa primeira leitura com algumas concepções a priori, com alguns conceitos predefinidos, postura que não deixa de ser hipotético-dedutiva. Entretanto, todo pesquisador, por mais dialético que se pretenda, em algum momento tem de ser hipotético-dedutivo, assim como, em outros, hermeneuta. Nesse sentido corroboro com Shirley Grundy as palavras de Hans-Georg Gadamer:

Gadamer afirma que, al tratar de comprender algo, nos aproximamos a ello com ciertas predisposiciones y significados previos (prejuicios). Mediante el proceso de comprensión o de interpretación de un texto, permitimos que nuestros propios prejuicios interactúen con el significado que el autor del texto trataba de comunicar, de modo que el texto resulte "significativo". (GADAMER, 1979, p. 236 apud GRUNDY, 1994, p. 98).

Embora tivesse algumas pressuposições, a seleção dos conceitos e das categorias, de modo geral, emergiu dos documentos. Ao lê-los confirmei, por exemplo, que seria necessário analisar o conceito de "sociedade do conhecimento", como aparece na Ley Orgánica de Educación (LOE), e variantes como "sociedade informática", como consta nos Parâmetros Curriculares Nacionais do Ensino Médio (PCNEM). Isso exige a discussão dos conceitos de informação, conhecimento e competência. Essa leitura também serviu para confirmar se a abordagem críticodialética seria de fato a opção mais adequada para o desenvolvimento da pesquisa.

Neste trabalho também utilizarei o método comparativo. Farei uma comparação entre o sistema de ensino brasileiro e espanhol do ponto de vista estrutural e curricular com base nos documentos dos respectivos Ministérios da Educação. Com isso espero estabelecer semelhanças e diferenças, aproximações e distanciamentos e, sobretudo, apreender as especificidades de cada sistema, tendo em vista as diferenças culturais, demográficas, econômicas e sociais dos dois países.

\section{Corpus dos documentos analisados na PESQUisa}

Do governo brasileiro, especialmente do Ministério da Educação (MEC), serão analisados os documentos a seguir. A Constituição de 1988 evidentemente 
não será analisada, mas será objeto de consulta na medida em que todos os outros textos legais se orientam por ela.

- Constituição da República Federativa do Brasil de 1988. (BRASIL, 1988).

- Lei n. 9394, 20 dezembro 1996. Estabelece as Diretrizes e Bases da Educação Nacional. (BRASIL,1996).

- Parâmetros Curriculares Nacionais do Ensino Médio: ciências humanas e suas tecnologias. (BRASIL, 1999).

- Parâmetros Curriculares Nacionais: Ensino Médio (PCNEM). (BRASIL, 2002a)

- PCN + Ensino Médio: Orientações Complementares aos Parâmetros Curriculares Nacionais. (BRASIL, 2002b).

- Diretrizes Curriculares Nacionais para o Ensino Médio (DCNEM) Resolução CEB n 3, 26 junho 1998. (BRASIL, 2002a).

- Proposta de regulamentação da base curricular nacional e de organização do Ensino Médio - Parecer CEB n 15, 1. junho 1998. (BRASIL, 2002a).

- Orientações Curriculares do Ensino Médio. (BRASIL, 2004a)

- Orientações Curriculares para o Ensino Médio, vol. 3. (BRASIL, 2006)

Nos antecedentes, como contraponto histórico, serão feitas referências às antigas LDB - Lei n. 5692, de 11 de agosto de 1971 (BRASIL, 1971), e Lei n. 4024, de 20 de dezembro de 1961 (BRASIL, 1961).

Em consonância com a LDB 9394/96, com o Parecer CEB 15/98 e com a Resolução CEB 3/98, foi lançada em 1999 a primeira versão impressa dos PCNEM. No portal do MEC há uma versão em formato pdf de 200026. Em 2002 foi lançada outra versão impressa da disponível na internet, porém revisada e com algumas pequenas alterações. As análises aqui feitas tomarão como base a versão impressa de 2002.

O PCNEM é dividido em quatro partes:

26 BRASIL. Ministério da Educação. Parâmetros Curriculares Nacionais Ensino Médio. Brasília: MEC, 2000. Disponível em: <http://portal.mec.gov.br/seb/arquivos/pdf/blegais.pdf>. Acesso em: 21 out. 2008. 
- Parte I - Bases Legais (na qual constam a LDB 9394/96, o Parecer CEB 15/98 e Resolução CEB 3/98);

- Parte II - Linguagens, Códigos e suas Tecnologias;

- Parte III - Ciências da Natureza, Matemática e suas Tecnologias;

- Parte IV - Ciências Humanas e suas Tecnológicas.

Do governo espanhol, especialmente do Ministerio de Educación y Ciencia (MEC), serão analisados ou consultados os seguintes documentos:

- Constitución Española de 1978. (ESPAÑA, 1996).

- Ley Orgánica 8/1985, de 3 de julio, Reguladora del Derecho a la Educación. (ESPAÑA, 1985).

- Ley Orgánica 1/1990, de 3 de octubre, de Ordenación General del Sistema Educativo. (ESPAÑA, 1990).

- Ley Orgánica 10/2002, de 23 de diciembre, de Calidad de la Educación. (ESPAÑA, 2002).

- Ley Orgánica 2/2006, de 3 de mayo, de Educación. (ESPAÑA, 2006a).

- Real Decreto 1007/1991, de 14 de junio, por el que se establecen las enseñanzas mínimas correspondientes a la educación secundaria obligatoria. (ESPAÑA, 1991a).

- Real Decreto 1007/1991, de 14 de junio, por el que se establecen las enseñanzas mínimas correspondientes a la educación secundaria obligatoria. (ESPAÑA, 1991b).

- Real Decreto 1178/1992, de 2 de octubre, por el que se establecen las enseñanzas mínimas del bachillerato. (ESPAÑA, 1992a).

- Real Decreto 1178/1992, de 2 de octubre, por el que se establecen las enseñanzas mínimas del bachillerato. (ESPAÑA, 1992b).

- Real Decreto 3473/2000, de 29 de diciembre, por el que se modifica el Real Decreto 1007/1991, de 14 de junio, por el que se establecen las enseñanzas mínimas correspondientes a la educación secundaria obligatoria. (ESPAÑA, 2001a). 
- Real Decreto 3474/2000, de 29 de diciembre, por el que se modifican el Real Decreto 1700/1991, de 29 de noviembre, por el que se establece la estructura del bachillerato, y el Real Decreto 1178/1992, de 2 de octubre, por el que se establecen las enseñanzas mínimas del bachillerato. (ESPAÑA, 2001b).

- Una educación de calidad para todos y entre todos: propuestas para el debate. (ESPAÑA, 2004).

- Real Decreto 1631/2006, de 29 de diciembre, por el que se establecen las enseñanzas mínimas correspondientes a la educación secundaria obligatoria. (ESPAÑA, 2007a).

- Real Decreto 1467/2007, de 2 de noviembre, por el que se establecen la estructura del bachillerato y se fijan sus enseñanzas mínimas. (ESPAÑA, 2007b). Nos antecedentes, como contraponto histórico, será feita referência à Ley 14/1970, de 4 de agosto, General de Educación y Financiamiento de la Reforma Educativa (ESPAÑA, 1970). 


\section{A SOCIEDADE DO CONHECIMENTO E AS REFORMAS EDUCACIONAIS}

Estamos em meio a uma nova revolução tecnológica. Alguns pesquisadores chamam-na de informacional (CASTELLS, 2000; LOJKINE, 1995), outros, de técnico-científica (SANTOS, 1996a), outros ainda, seguindo a tradição cronológica, de terceira revolução industrial (KUMAR, 1997). Seja lá que nome se utilize para defini-la, o fato é que essa nova revolução tecnológica vem impondo profundas mudanças nas relações sociais, na economia, na cultura, na política e no espaço geográfico, especialmente na experiência do espaço-tempo. De acordo com Leyshon (1995), está havendo uma convergência no tempo-espaço (isso será analisado com base na figura 4). É de esperar, portanto, que a atual revolução tecnológica imponha mudanças também ao sistema educativo, que em quase todos os países vive premido pela necessidade de se adaptar.

A profusão de reformas educacionais que estão sendo discutidas e/ou implementadas em diversos países é um forte indício da busca de adequação da Educação ao sistema econômico atual, marcado por crescente competição entre empresas, lugares e nações, na qual o conhecimento ganha cada vez maior relevância. Como afirma Gimeno Sacristán (2000, p. 20):

A relação de determinação sociedade-cultura-currículo-prática explica que a atualidade do currículo se veja estimulada nos momentos de mudanças nos sistemas educativos, como reflexo da pressão que a instituição escolar sofre desde diversas frentes, para que adapte seus conteúdos à própria evolução cultural e econômica da sociedade.

Apple levanta uma questão que tem tudo a ver com as transformações ocorridas no que vem sendo chamado de sociedade do conhecimento e suas implicações no sistema educacional e na definição do currículo: "De quem é o conhecimento de maior valor?" (2006, p. 21). Com isso, numa perspectiva crítica, lembra-nos, com Gimeno Sacristán, que o currículo expressa uma relação dialética escola-sociedade, uma sociedade, em cada país, marcada por divisão de classes e por conflitos de interesse. Portanto, o currículo espelha essa realidade, não é neutro, como a visão tecnicista tenta nos convencer. Com isso, a organização curricular tem 
sido orientada por um interesse técnico e, portanto, assentada na ação instrumental, voltada para o controle.

As relações entre o processo de produção do conhecimento e a Educação são evidentes. Além disso, vários autores têm afirmado que entramos numa sociedade do conhecimento ou da informação (CASTELLS, 2000; DRUCKER, 1997; GORZ, 2005; HARGREAVES, 2004). Para compreender essas questões, é importante antes elucidar alguns conceitos fundamentais como dados, informações e conhecimentos.

Para analisar o papel do conhecimento no mundo contemporâneo e, conseqüentemente, sua inserção nas reformas educacionais, especialmente nas curriculares, é crucial verificar a mudança de sua natureza ao longo da História. Evidentemente que aqui não será feito um trabalho de epistemologia histórica, mas apenas uma verificação do papel do conhecimento nos vários momentos que marcam o desenvolvimento humano. Para tanto vou apoiar-me na categoria "modos de desenvolvimento", proposta por Castells (2000).

\section{Conceitos informacionais}

No senso comum e, às vezes, mesmo nos meios científicos, os conceitos de informação e conhecimento são utilizados imprecisamente e, muitas vezes, de forma intercambiável. Num mundo em que o conhecimento ganha cada vez mais importância e ao mesmo tempo somos inundados por uma crescente quantidade de informação, parece que esses conceitos têm o mesmo significado. Entretanto, um breve levantamento de algumas conceituações mostra que, na realidade, não é isso o que ocorre. Manuel Castells, por exemplo, citando Porat, afirma que "informação são dados que foram organizados e comunicados". (PORAT, 1977, p. 2 apud CASTELLS, 2000, p. 45). Resta saber o que são dados. Para Japiassu e Marcondes (2006), dado é tudo aquilo que a experiência apresenta ao observador como objeto de simples constatação, ou seja, é tudo o que é imediatamente apresentado ao espírito antes de uma elaboração consciente. De acordo com Simon (1999, p. 17), 
dado "é uma seqüência de símbolos, é um ente totalmente sintático, não envolve semântica como na informação. Os dados podem ser representados com sons, imagens, textos, números e estruturas.". Parece evidente que, para existir informação, o ente semântico, é preciso antes haver a elaboração do dado, o ente sintático, e depois sua comunicação. Assim, podemos afirmar que a informação é o dado com algum significado, com algum sentido.

O próximo passo é a definição do conceito de conhecimento, o que, embora possa parecer, não é nada trivial. Castells (2000, p. 45), na primeira edição do livro $A$ sociedade em rede, diz não ter nada a acrescentar à definição dada por Daniel Bell em seu famoso livro El advenimiento de la sociedad post-industriap7. Então, vamos ao original. O sociólogo norte-americano define o conhecimento como "un conjunto de exposiciones ordenadas de hechos e ideas, que presentan un juicio razonado o un resultado experimental, que se transmite a otros a través de algún medio de comunicación bajo una forma sistemática”. (BELL, 2006, p. 206). Com isso, diz em seguida, busca diferenciar o conhecimento das noticias e dos entretenimentos; das informações, eu diria.

Observe que essa definição sugere que "conhecimento" é sinônimo de "conhecimento científico", sobretudo quando fala em "julgamento ponderado ou resultado experimental". Em outro trecho, reforçando ainda mais essa sinonímia, Bell propõe uma definição mais restrita para fins de política social: "el conocimiento es lo que se conoce objetivamente, una propiedad intelectual, ligado a un nombre o a un grupo de nombres y certificado por el copyright o por alguna otra forma de reconocimiento social (por ejemplo, la publicación)". (BELL, 2006, p. 207, grifo do autor).

Perrenoud (1999, p. 7, grifo do autor) ao afirmar que conhecimentos "são representações da realidade que construímos e armazenamos ao sabor de nossa experiência e de nossa formação", coloca-se no extremo oposto à definição de Bell (2006). Como cada um vivencia a realidade e a representa de forma particular, nesse caso o conhecimento é algo pessoal e, diria, senso comum. Uma definição situada entre as duas anteriores é oferecida por Johnson (1997, p. 48):

\footnotetext{
Do original em inglês The coming of the post-industrial society, publicado em 1973.
} 
Conhecimento é aquilo que consideramos como real e verdadeiro. Pode ser tão simples e banal como dar o laço nos sapatos ou tão abstrato e complexo como a física de partículas. O conhecimento é importante para a sociologia porque é socialmente criado e também porque dele dependemos para nosso senso de realidade

Aqui é necessária uma ressalva. Embora os físicos possam discordar da afirmação de que a física de partículas seja algo abstrato, já que as partículas são constituintes elementares de toda matéria, as pessoas no senso comum e mesmo cientistas de outras áreas, como é o caso do sociólogo Allan Johnson, têm essa impressão. Talvez porque não enxerguemos as partículas elementares que compõem a matéria. Mas, indiscutivelmente, trata-se de um conhecimento muito mais complexo e especializado em comparação com o que assegura nosso senso cotidiano de realidade.

Com base nessas definições, é razoável inferir que conhecimento não é apenas a produção científica, gerada de acordo com os cânones acadêmicos, mas também o conhecimento tácito, o senso comum, intuitivo, as experiências individuais e coletivas que movem as pessoas em seu dia-a-dia. De fato, corroborando essa conclusão, Gimeno Sacristán afirma que "o conhecimento e tudo o que povoa de significados o termo teoria não pode reduzir-se ao conhecimento científico, como pretendeu o cientificismo positivista". (1999, p. 58, grifo do autor).

Entretanto, é responsabilidade da escola avançar do senso comum ao conhecimento que se ancora nos paradigmas da ciência, avançar do conhecimento tácito ao explícito. É interessante o ponto de vista de Lefebvre (1991, p. 67), para quem "o conhecimento humano progride da ignorância à ciência". E isso se dá por meio do desvendamento, do estudo, da pesquisa. Mas, numa perspectiva educacional, vale considerar o alerta de Gimeno Sacristán (1999, p. 59):

As fronteiras entre a ciência e as outras formas de conhecimento não são tão nítidas, porque, por vezes são maneiras heterogêneas que apresentam continuidades e interferências. As pessoas não costumam guiar sua vida pela ciência, mas por outras formas de conhecimento, e essa bagagem não pode ser depreciada quando queremos entender a educação e seus agentes. 
Ou seja, o aluno tem sempre uma bagagem de conhecimentos a priori, nunca parte da total ignorância. Ao mesmo tempo, matizando a afirmação de Lefebvre, mesmo com a ciência, nunca deixaremos completamente a ignorância.

O filósofo francês disse também que o conhecimento é um fato, é prático, é social e tem um caráter histórico. Em seguida enuncia que: "Cada época deve esforçar-se por organizar, sistematizar numa 'síntese', o conjunto de conhecimento sobre a natureza. Mas nenhuma dessas sínteses pode se pretender definitiva." (LEFEBVRE, 1991, p. 67). Com isso coloca a importante questão de que o conhecimento é movimento, é histórico. Daí, como vimos, a importância da análise do momento presente proposta pela teoria crítica.

Assim, ao tentar conceituar as palavras-chave para essa discussão, devemos ter claro que todo conceito é histórico e, conseqüentemente, dinâmico. Como qualquer conceito é sempre uma tentativa de abstrair a realidade, de reconstruí-la no plano do pensamento, caso esta mude, aquele também deve mudar. De fato, como nos lembra Lefebvre (1991, p. 90): "Todo pensamento é movimento.".

Machado (2000), numa tentativa de definir os conceitos acima e antes de tudo organizar sua operacionalização, constrói o que chama de "pirâmide informacional", como mostra a figura 1:

Figura 1. Pirâmide informacional

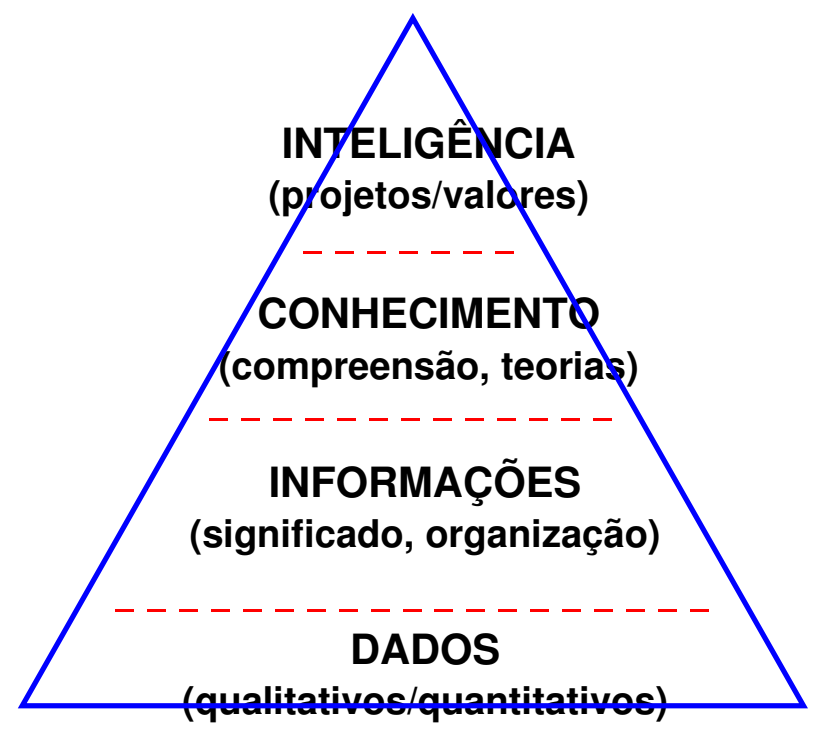


Nessa pirâmide, os dados referem-se aos elementos qualitativos e quantitativos da realidade, podem ser acumulados e processados, remetendo, portanto, à idéia de banco, onde são armazenados. São os elementos mais disseminados na realidade, mas isoladamente não têm interesse. De fato, são as pessoas que manifestam interesse por determinado dado, que o elaboram, que lhe atribuem sentido, produzindo informação com base nele. Noutras palavras, é o sujeito que produz a informação a partir do dado. É a pergunta apropriada ao dado que permite a extração da informação pretendida. Sobre os dados, Machado (2000, p. 66) argumenta que: "Seu valor informacional depende justamente da existência de pessoas interessadas, que os organizem e lhes atribuam significado, transformandoos em informação.". Entretanto, alerta para o fato de que o simples acúmulo de informação não garante a passagem para o terceiro nível da pirâmide, não garante a produção de conhecimentos.

Enquanto o conceito de dado remete a banco, à idéia de acumulação, informação remete a veículo, à idéia de comunicação. De fato, sem comunicação não há informação, como já afirmou Castells (2000). Aliás, sem comunicação também não há conhecimento nem relação intersubjetiva. Quem já não teve a oportunidade de tentar ler um livro num idioma desconhecido sem conseguir extrair nenhuma informação, nem conhecimento, ou tentar se comunicar com uma pessoa que fala uma língua incompreendida?

O conhecimento, o terceiro nível da pirâmide informacional proposta por Machado, remete à idéia de teoria, de compreensão. Mas a comunicação em si não garante a compreensão. Falando sobre a internet, que considera um fato universal importantíssimo, Morin (2008, p. A14) alerta: "Mas os sistemas de comunicação não criam compreensão. A comunicação apenas transmite a informação.". Para atingir o conhecimento e produzir compreensão "é fundamental a capacidade de estabelecer conexões entre elementos informacionais aparentemente desconexos, processar informações, analisá-las, relacioná-las, armazená-las, avaliá-las segundo critérios de relevância, organizá-las em sistemas”. (MACHADO, 2000, p. 67-68). Realmente, como propõe Marina (1995, p. 40): “conhecer é compreender, quer dizer, apreender 
o novo com o já conhecido". Noutras palavras, para a produção do conhecimento científico é necessário inserir as informações num arcabouço teórico-metodológico que permita a compreensão da realidade. Daí a importância da discussão sobre os conceitos e categorias da Geografia, como veremos na parte III deste trabalho, especialmente no capítulo 1.

Porém, mesmo o conhecimento senso comum está ancorado em certas "teorias", ou seja, em crenças, muitas vezes sem nenhuma fundamentação, que buscam explicar a realidade. "Não é possível uma observação sem teoria, porque a quantidade de informações é demasiado grande, demasiado confusa, demasiado incompleta", como diz Marina (1995, p. 40), com quem concordo inteiramente. Machado (2000), remetendo-se a esse filósofo espanhol, afirma que o conhecimento é o meio para as pessoas realizarem seus projetos. Mais do que uma definição, é uma busca de operacionalização do conceito de conhecimento. E falar de pessoas e de projetos implica considerar valores, o que nos remete ao conceito que aparece no topo da pirâmide informacional, a inteligência, ou melhor, as inteligências.

Sem a pretensão de aprofundar esse complexo conceito, até porque pouco vou operacionalizá-lo neste trabalho, gostaria apenas de lembrar que inteligência pode ser concebida como: a) medida, b) espectro de competências e c) interação de projetos e valores.

a) Como medida, esse conceito é utilizado desde o início do século $X X$, quando o psicólogo e pedagogo francês Alfred Binet inventou os primeiros testes de QI (Quociente de Inteligência). Embora esses testes tenham sido aprimorados e utilizados por muito tempo, vêem a inteligência como uma medida unidimensional, o que fez sua importância diminuir muito recentemente (MACHADO, 2000).

b) A inteligência é considerada um espectro de competências pelo psicólogo norte-americano Howard Gardner. Crítico contumaz dos testes de QI, vem desenvolvendo a teoria das inteligências múltiplas desde os anos 1980. Gardner (2000) propõe que há sete inteligências: a lingüística, a lógico-matemática, a corporal-cinestésica, a espacial, a musical, a inter-pessoal e a intra-pessoal. Mais tarde passa a considerar a possibilidade de haver mais duas: a naturalista e a existencial (GARDNER, 2006). Para ele, todas as pessoas têm essas inteligências, 
que funcionam de forma integrada, mas alguns indivíduos, por razões genéticas e ambientais, têm maior potencial para desenvolver umas mais que outras. Por conta dessa sua crença, Gardner (2000) é contrário a uma educação escolar uniforme, como a existente nos Estados Unidos (na Espanha, e especialmente no Brasil, o currículo da escola básica é mais uniforme ainda). Defende uma educação escolar centrada no potencial individual do aluno, com um currículo flexível que se adapte aos diferentes perfis de inteligência. Trata-se de uma formulação que contraria o modelo de escola básica com um currículo uniforme, defendido por muitos, especialmente na Espanha, como veremos no capítulo 2 da parte II, como um ideal democrático.

Gardner (2000) critica não apenas a escola, sobretudo a norte-americana, e os testes de QI, por valorizarem demasiadamente os eixos lingüístico e lógicomatemático, como também o psicólogo e educador suíço Jean Piaget, para quem o conceito de inteligência era sinônimo de inteligência lógico-matemática. Afirma também que o fato de estudantes serem bem-sucedidos (ou não) em testes de QI em geral indica apenas que eles se saem bem (ou não) no ambiente escolar, no qual se valoriza sobremaneira aquele eixo. Há vários exemplos, na História, de pessoas que foram consideradas maus estudantes e depois se tornaram bons profissionais, alguns brilhantes e extremante valorizados em seu campo de atuação. Provavelmente, suas inteligências com maior potencial de desenvolvimento não tenham sido valorizadas ou estimuladas na escola.

Essa discussão sobre cognição humana, embora muito interessante, foge ao escopo deste trabalho. Portanto, limito-me a essas observações apenas para indicar uma promissora possibilidade de pensar a inteligência humana, especialmente sob a perspectiva educacional.

c) Finalmente, a inteligência pode ser definida como interação entre projetos e valores, como propõe Marina (1995, p. 14):

Inteligência é, evidentemente, a capacidade de resolver equações diferenciais, mas acima de tudo é a aptidão para organizar comportamentos, descobrir valores, inventar projetos e mantê-los, ser capaz de libertar-se do determinismo da situação, solucionar problemas, analisá-los. 
Por isso Machado (2000, p. 68) afirma que "a inteligência encontra-se diretamente associada à capacidade de ter projetos; a partir deles, dados, informações, conhecimentos são mobilizados ou produzidos".

O que de fato importa, especialmente numa perspectiva emancipatória, é a realização dos projetos das pessoas e também da comunidade em que vivem. Assim, dados, informações e especialmente conhecimentos passam a ser meios para a realização de projetos pessoais e/ou coletivos. Ou seja, estão a serviço da inteligência humana, que é plural e não pode ser encerrada num teste de papel e lápis. Por mais que vejamos sua associação com coisas, como prédios inteligentes ${ }^{28}$, trata-se de um atributo essencialmente humano.

28 Na Torre Mayor, na cidade do México, considerada um dos primeiros "edifícios inteligentes" do país, nas informações sobre o sistema anti-sismo, consta que "o edifício sabe quando vai haver um terremoto". Esse é um bom exemplo de reificação, de fetichismo que atribui vida própria e, portanto, inteligência ao prédio, obscurecendo o fato de que ele é uma coisa, uma construção humana. Inteligentes são as pessoas, os profissionais, que o projetaram, o construíram e o controlam. 


\section{O advento da sociedade do conhecimento}

Desde que iniciou sua aventura na Terra, o ser humano produz informações e conhecimentos. Por isso, designações como era ou sociedade da informação (CASTELLS, 2000), sociedade ou economia do conhecimento (DRUCKER, 1997; GORZ, 2005) não seriam apropriadas para apreender a especificidade do momento presente, do atual período histórico. Informação e conhecimento sempre fizeram parte da qualquer sociedade ou sistema econômico, em qualquer momento da História. Como nos alerta Postman (1994, p. 70): "Nada pode ser mais enganador do que a afirmação de que a tecnologia do computador introduziu a era da informação.”. Para Postman, a prensa tipográfica de Gutenberg iniciou a era da informação no início do século XVI. Porém, vale questionar: ou teria sido muito antes disso, no momento da invenção da própria escrita? O fato é que a invenção de Gutenberg iniciou a produção da informação em grande escala, o que foi ampliado exponencialmente pelo computador, porém a produção de informação é anterior à prensa.

Castells (2000) chama a atenção para isso na primeira edição de seu livro Sociedade em rede, o primeiro volume da trilogia $A$ era da informação: economia, sociedade e cultura, e, na tentativa de apreender as especificidades do momento presente, propõe denominá-lo de "era informacional" ou "sociedade informacional". Apesar disso, mantém "era da informação" no título da coleção com a justificativa de que títulos são dispositivos que devem ser suficientemente claros e abrangentes para chamar a atenção para o tema tratado. Argumenta que todos fazem uma idéia do que seria uma "era da informação".

De fato, como mostra a tabela 1, em textos e documentos disponíveis em português na internet, o termo "era da informação" é bem mais utilizado que "era informacional", o mesmo ocorrendo com os termos correspondentes em espanhol e em inglês. Entretanto, o termo mais utilizado em português na rede é "sociedade da informação", em espanhol, "sociedad de la información" e, em inglês, "information society". A quantidade de ocorrências na internet expressa a maior ou menor 
utilização de um termo. Independentemente de sua precisão, é uma busca de operacionalização conceitual e pode ser um indício de qual conceito será hegemônico, o que pode nem ser o mais preciso.

A propósito, Machado (2004, p. 123) questiona a precisão conceitual do debate atual quando, de forma irônica, dispara: "Às vezes, a sociedade em que vivemos é rotulada de 'sociedade do conhecimento'; outras vezes, de 'sociedade da informação'. Mas, em grande medida, ela não passa de uma 'sociedade dos bancos de dados'. $29 "$.

\begin{tabular}{|l|c|c|c|}
\hline \multicolumn{4}{|c|}{$\begin{array}{c}\text { Tabela 1. Resultados da busca de termos na opção "a web" do } \\
\text { Google Brasil (em 12 mar. 2008) }\end{array}$} \\
\hline \hline Termos pesquisados" & português & espanhol & Inglês \\
\hline \hline "Sociedade da informação" & 344.000 & 3.700 .000 & 3.780 .000 \\
\hline "Sociedade do conhecimento" & 236.000 & 507.000 & 634.000 \\
\hline "Sociedade informacional" & 6.680 & 14.100 & 22.300 \\
\hline \hline "Era da informação" & 295.000 & 293.000 & 116.000 \\
\hline "Era do conhecimento" & 176.000 & 113.000 & 57.700 \\
\hline "Era informacional" & $2.530^{31}$ & 2.530 & 2.160 \\
\hline \hline "Economia do conhecimento" & 84.800 & 314.000 & 1.190 .000 \\
\hline "Economia da informação" & 52.800 & 228.000 & 955.000 \\
\hline "Economia informacional" & $1.980^{32}$ & 6.250 & 9.810 \\
\hline
\end{tabular}

Fonte: Google Brasil. Disponível em: <www.google.com.br>. Acesso em: 12 mar. 2008.

Buscando dar uma explicação conseqüente para a mudança no papel da informação e do conhecimento ao longo da História, Castells (2000) utiliza a categoria "modo de desenvolvimento". Para o sociólogo espanhol, "os modos de desenvolvimento são os procedimentos mediante os quais os trabalhadores atuam sobre a matéria para gerar o produto, em última análise, determinando o nível e a

29 Na pesquisa feita no Google Brasil, em 12 mar. 2008, "sociedade de dados" obteve 97.200 resultados;

"sociedad de datos", 187.000; e "data society", 21.900.

30 Os termos correlatos pesquisados em espanhol e inglês foram, respectivamente: Sociedad de la información, Information society; Sociedad del conocimiento, Knowledge society; Sociedad informacional, Informational society; Era de la información, Information era; Era del conocimiento, Knowledge era; Era informacional, Informational era; Economía del conocimiento, Knowledge economy; Economía de la información, Information economy; Economía informacional, Informational economy.

31 A pesquisa em "páginas em português" do Google Brasil obteve 1.220 resultados; em "páginas en español" do Google España, 1.130.

32 A pesquisa em "páginas em português" do Google Brasil obteve 1.760 resultados, em "páginas en español" do Google España, 13.800. 
qualidade do excedente". (CASTELLS, 2000, p. 34). Assim, a História humana foi marcada por diferentes modos de desenvolvimento: o agrário, o industrial e o informacional. O que os diferenciam é basicamente o fator de produção mais importante, o que está atrelado ao grau de desenvolvimento tecnológico vigente em cada um deles e ao nível de produtividade.

No modo de desenvolvimento agrário, vigente desde o neolítico, o fator de produção mais importante era a terra. O trabalhador atuava sobre a terra com o objetivo de produzir os meios de subsistência, como os alimentos. Por séculos, diferenças de produtividade estiveram mais ligadas à variabilidade de fertilidade natural dos solos do que aos avanços tecnológicos.

Com o advento das revoluções industriais, a humanidade atingiu o modo de desenvolvimento industrial. A partir da era industrial, os fatores de produção mais importantes passaram a ser as matérias-primas e as fontes de energia. Da perspectiva da Geografia houve uma crescente tecnificação do território, uma enorme expansão do que Santos (1996a) chamou de meio técnico. A partir daí, todas as sociedades industrializadas passaram gradativamente a funcionar segundo a lógica do industrialismo: a produção e a circulação de bens maquinofaturados; a agricultura, com a crescente mecanização; e até a cultura, como nos mostraram Adorno e Horkheimer (1985), ao criarem o conceito de "indústria cultural".

De acordo com a caracterização de Castells (2000), hoje estaríamos vivendo em pleno modo de desenvolvimento informacional. Deixamos de ser agrários e industriais? A terra, as matérias-primas e as fontes de energia deixaram de ser importantes? Nem é preciso dizer que continuamos a nos alimentar, logo nossa espécie continua sendo agrária. A quantidade crescente de produtos maquinofaturados disponíveis também não deixa dúvidas de que continuamos sendo industriais. O que ocorre é que, como aconteceu antes com o industrialismo, a lógica do informacionalismo comanda todos os setores das sociedades contemporâneas, pelo menos das tecnologicamente mais avançadas.

Com o termo "informacional", Castells busca apreender o fato de que o conhecimento transformou-se no principal fator de produção no mundo atual. Em suas palavras: 
No novo modo informacional de desenvolvimento, a fonte de produtividade acha-se na tecnologia de geração de conhecimentos, de processamento de informação e de comunicação de símbolos. Na verdade, conhecimentos e informação são elementos cruciais em todos os modos de desenvolvimento, visto que o processo produtivo sempre se baseia em algum grau de conhecimento e no processamento da informação. Contudo, o que é específico ao modo informacional de desenvolvimento é a ação de conhecimentos sobre os próprios conhecimentos como principal fonte de produtividade. (CASTELLS, 2000, p. 35).

Embora as idéias defendidas pelo sociólogo espanhol tenham tido grande divulgação e aceitação, elas não são originais. O pioneiro nessa senda analítica, como vimos, foi o sociólogo norte-americano Daniel Bell, no livro El advenimiento de la sociedad post-industrial. Nessa publicação, em que criou o termo "sociedade do conhecimento", já afirmava que a economia estava saindo de uma era industrial, na qual a maioria das pessoas estava envolvida na produção de coisas, para uma era pós-industrial, na qual o trabalho estava cada vez mais envolvido com a produção de conhecimentos. De acordo com ele:

La sociedad industrial se caracteriza por la coordinación de máquinas y hombres para la producción de bienes. La sociedad post-industrial se organiza en torno al conocimiento para lograr el control social y la dirección de la innovación y el cambio, y esto a su vez da lugar a nuevas relaciones sociales y nuevas estructuras que tienen que ser dirigidas políticamente. (BELL, 2006, p. 34).

Depois da constatação quanto à mudança do papel do conhecimento, Bell afirma quase a mesma coisa que Castells afirmara acima: "Ahora bien, el conocimiento ha sido siempre necesario para el funcionamiento de cualquier sociedad. Lo que caracteriza a la sociedad post-industrial es el cambio en el carácter del conocimiento mismo." (BELL, 2006, p. 34).

O economista antimarxista norte-americano Peter Drucker também defendeu essas idéias antes de Castells:

O recurso econômico básico - "os meios de produção", para usar uma expressão dos economistas - não é mais o capital, nem os recursos naturais (a "terra" dos economistas), nem a "mão-de-obra". Ele é e será o conhecimento. As atividades centrais de criação de riqueza não serão nem a alocação de capital para usos produtivos, nem a "mão-de-obra" - os dois pólos da teoria econômica dos séculos dezenove e vinte, quer ela seja clássica, marxista, keynesiana ou neoclássica. Hoje o valor é criado pela "produtividade" e pela "inovação", que são aplicações do conhecimento ao trabalho. (DRUCKER, 1997, p. XVI, grifo do autor). 
Drucker defende que, nos primórdios da industrialização, o conhecimento era aplicado às ferramentas, aos processos e aos produtos, o que caracterizou a Revolução Industrial. Em sua segunda fase, iniciada no final do século XIX e culminando com a Segunda Guerra, o conhecimento passou a ser aplicado ao trabalho, caracterizando o que chama de "Revolução da Produtividade", que alçou os trabalhadores à condição de classe média e freou "a guerra de classes e o comunismo". Uma visão conservadora e, portanto, otimista para uma realidade que Adorno e Horkheimer (1985) viam de forma aporética.

Para Drucker, atualmente estamos vivendo uma "Revolução Gerencial": "Hoje em dia, o conhecimento está sendo aplicado ao próprio conhecimento. [...] $\mathrm{O}$ conhecimento está rapidamente se transformando no único fator de produção, deixando de lado capital e mão-de-obra." (1997, p. 4, grifo do autor). Embora exagere quando diz que o conhecimento será o "único" fator de produção, são palavras muito semelhantes às proferidas por Castells (2000). Apesar de seu otimismo de futurologista, afirma ser temerário chamar o mundo em que vivemos de "sociedade do conhecimento": "Pode ser prematuro (e certamente presunçoso) chamar nossa sociedade de 'sociedade do conhecimento'; por enquanto, temos somente uma economia do conhecimento." (DRUCKER, 1997, p. 4). Neste ponto, estou de acordo com ele, porque o conhecimento ainda é fortemente instrumentalizado pelo interesses do capital e não é democratizado.

André Gorz também vê o conhecimento como a principal força produtiva do sistema econômico atual; também fala em "economia do conhecimento" em vez de "sociedade do conhecimento".

Se não for uma metáfora, a expressão 'economia do conhecimento' significa transtornos importantes para o sistema econômico. Ela indica que o conhecimento se tornou a principal força produtiva, e que, conseqüentemente, os produtos da atividade social não são mais, principalmente, produtos do trabalho cristalizado, mas sim do conhecimento cristalizado. Indica também que o valor de troca das mercadorias, sejam ou não materiais, não mais é determinado em última análise pela quantidade de trabalho social geral que elas contêm, mas, principalmente, pelo seu conteúdo de conhecimentos, informações, de inteligências gerais. (GORZ, 2005, p. 29). 
Com isso põe em cheque a histórica noção de mais-valia ${ }^{33}$, já que cada vez mais o que valoriza as mercadorias é o conhecimento e não o trabalho. Entretanto, não desprezemos tão prontamente o trabalho. Formulações como as que pregam que "o conhecimento age sobre o próprio conhecimento" ou "o conhecimento substitui a mão-de-obra" também podem ser situadas como exemplos de reificação, de fetichismo. Tais afirmações mascaram 0 fato de que 0 conhecimento não tem vida própria e, mais ainda, ele só pode se manifestar na pessoa, no sujeito; no caso, no trabalhador especializado. Não é por acaso que o capital exige cada vez mais qualificação (ou competência, veremos isso a seguir) da mão-de-obra e que os trabalhadores mais bem preparados sejam tão valorizados no mercado laboral. Isso tem implicações importantes para a Educação e está na base de todos os discursos reformistas. A propósito, é interessante o paralelo que se pode fazer entre o problema da distribuição, de que fala Fernández Enguita (2006b) no trecho a seguir, e os "modos de desenvolvimento", propostos por Castells (2000). No modo de desenvolvimento informacional, o problema crucial é a distribuição do conhecimento:

En una economía agraria, de hogares en gran medida autosuficientes, el problema distributivo era ante todo, aunque no sólo, el de la distribución de la tierra (y el gran ideal de justicia: la tierra para el que la trabaja); en una economía industrial, cuyo nervio y paradigma es la fábrica, el problema es la distribución de la propiedad del capital ( $y$, el ideal, da socialización de los medios de producción); en una economía post-industrial, de la información, el problema es la distribución del conocimiento (y, el ideal, la igualdad o las oportunidades educativas para todos). (FERNÁNDEZ ENGUITA, 2006b, p. 89)

Dessas afirmações, pode-se depreender que a chamada sociedade do conhecimento é marcada pela crescente instrumentalização deste importante recurso pelo capital e isso fica mais evidente quando se fala em "economia do conhecimento". Como nos lembra Gorz (2005), isso teve início já final do século XIX, na Alemanha, quando Karl Duisberg, por volta de 1880, pela primeira vez industrializou o trabalho de pesquisa na indústria química Bayer. No laboratório, a

33 Conceito central da economia política marxista, define o valor do trabalho não pago ao operário e apropriado pelo capitalista. Para Marx (1978, p. 83, grifo do autor): “A taxa de mais-valia dependerá, se todas as outras circunstâncias permanecerem invariáveis, da proporção existente entre a parte da jornada que o operário tem que trabalhar para reproduzir o valor da força de trabalho e o sobretempo ou sobretrabalho realizado para o capitalista.". 
produção de conhecimento foi submetida à mesma lógica da divisão e hierarquização do trabalho existente na indústria. Hoje em dia, isso foi levado às últimas conseqüências nos Estados Unidos, de longe o país líder em termos tecnológicos. Talvez por isso o uso do termo "economia do conhecimento" é maior em inglês do que nas outras duas línguas (ver tabela 1).

Nos primórdios dessa instrumentalização, o conhecimento em si não era valor de troca, mas as mercadorias, os produtos químicos que o incorporavam e que ele valorizava, sim. De lá para cá, isso tomou um vulto enorme e hoje em dia o conhecimento em si tem se transformado no principal fator de produção, na principal fonte de valor e de lucro. Como diz Hargreaves (2004, p. 34):

Uma economia do conhecimento não funciona a partir da força das máquinas, mas a partir da força do cérebro, do poder de pensar, aprender e inovar. As economias industriais precisam de trabalhadores para as máquinas; a economia do conhecimento precisa de trabalhadores para o conhecimento.

O conhecimento como valor de troca em si tem uma peculiaridade, a sua raridade tem de ser definida artificialmente, daí as restrições de circulação estabelecidas por patentes, direitos autorais, licenças etc. Isso vale especialmente para produtos que, como os programas de computadores, custam muito para serem desenvolvidos e muito pouco para serem reproduzidos. A pirataria é uma forma de tentar burlar isso.

Mas a característica mais "revolucionária" do conhecimento, o que não havia antes e é intrínseco da era informacional, é que ele ganha uma crescente autonomia. Pode, por exemplo, na forma de sistemas computacionais: gerir negócios, indústrias, bancos, bolsas de valores virtuais, em lugares distintos; controlar máquinas, como os robôs, e sistemas de produção flexível, como o just-intime e o kanban. Ou seja, pode fazer o papel de capital fixo (GORZ, 2005). Apesar disso, não podemos esquecer que quem produz e opera esses sistemas computacionais são pessoas - trabalhadores especializados - e que os detentores desse capital fixo, os capitalistas, são movidos por interesses. Disso pode-se inferir que o conhecimento, assim como põe em cheque a mais-valia, é crescentemente responsável pela intermediação e pelo esmaecimento do conflito de classes. 
Para Gorz, o conhecimento destrói mais valor do que produz, economiza mais trabalho do que gera, reduzindo assim o valor de troca monetária de uma grande gama de produtos e serviços. Com isso há menos trabalho incorporado e, conseqüentemente, menos meios de pagamento, menos distribuição de renda, a ponto de Gorz (2005, p. 37) vaticinar: "O 'capitalismo cognitivo' é a crise do capitalismo em seu sentido mais estrito.". Parece uma afirmação um tanto peremptória, já que estamos apenas no começo a era informacional.

O conhecimento é responsável pela valorização dos produtos, dos processos produtivos, dos serviços e também do território, constituindo, nesse caso, o que Santos (1996a) chamou de meio técnico-científico-informacional, segundo ele, a cara da globalização. Então, pode-se dizer que o meio técnico-científicoinformacional é a base territorial da sociedade informacional ou do conhecimento.

O modo de desenvolvimento informacional, na proposição de Castells (2000), encampou os setores que eram típicos dos modos de desenvolvimento precedentes. Hoje em dia a agricultura e a indústria funcionam sob a lógica do informacionalismo.

A soja que o Brasil cultiva no cerrado tropical, por exemplo, é uma criação dos técnicos da Empresa Brasileira de Pesquisa Agropecuária (EMBRAPA), já que o grão é natural de zonas temperadas. Essa soja não é um produto natural, mas uma criação humana, portanto prenhe de conhecimento.

Da mesma forma, um automóvel, produto por excelência da era do industrialismo, mais especificamente da segunda revolução industrial, do regime de acumução fordista (HARVEY, 1993), hoje é um produto informacional. Os carros atuais, mesmo os modelos mais simples e baratos, não têm nada que ver com os pioneiros, como o famoso Ford T. Embora o princípio básico de propulsão ainda seja o mesmo, motores com injeção eletrônica, computadores de bordo, navegação via GPS, entre outros equipamentos gestados na atual revolução tecnológica, transformaram o automóvel num produto informacional.

Enquanto as duas precedentes foram revoluções de energia - a primeira movida por carvão, a segunda por petróleo e eletricidade -, a terceira revolução industrial, a atual, é "movida" pelo conhecimento. Não que a energia tenha deixado 
de ser importante. Um computador, produto informacional por excelência, não funciona sem eletricidade. Porém, essa fonte de energia é originária da segunda revolução industrial. Não há uma fonte de energia nova que movimente a terceira revolução industrial, a base energética atual vem das duas anteriores, sobretudo da segunda. Mas, sem dúvida, o conhecimento é, para o bem e para o mal, o grande motor da era informacional.

Essas mudanças também podem ser interpretadas da perspectiva da chamada "escola da regulação". Para seus idealizadores, a cada regime de acumulação está associado um modo de regulação. De acordo com Lipietz (1991, p. 28), um dos autores regulacionistas, um regime de acumulação expressa:

[...] a lógica e as leis macroeconômicas que descrevem as evoluções conjuntas, por um longo período, das condições da produção (produtividade do trabalho, grau de mecanização, importância relativa dos diferentes ramos), bem como das condições de uso social da produção (consumo familiar, investimentos, despesas governamentais, comércio exterior).

Já o modo de regulação "é a combinação dos mecanismos que efetuam o ajuste dos comportamentos contraditórios, conflituosos, dos indivíduos, aos princípios coletivos do regime de acumulação". (LIPIETZ, 1991, p. 28). É preciso que haja coerência entre os dois para que o sistema capitalista funcione adequadamente. Se um muda, o outro acaba tendo que mudar também.

Desde o final dos anos 1970 o mundo vem vivenciando uma mudança de paradigma produtivo e tecnológico, de regime de acumulação. Estamos saindo do regime de acumulação fordista, associado ao modo de regulação keynesiano, para o regime de acumulação flexível (HARVEY, 1993) ou liberal-produtivista (LIPIETZ, 1991), associado ao modo de regulação liberal ou, mais precisamente, neoliberal. Para Harvey (1993, p. 140, grifo do autor):

A acumulação flexível, como vou chamá-la, é marcada por um confronto direto com a rigidez do fordismo. Ela se apóia na flexibilidade dos processos de trabalho, dos mercados de trabalho, dos produtos e padrões de consumo. Caracteriza-se pelo surgimento de setores de produção inteiramente novos, novas maneiras de fornecimento de serviços financeiros, novos mercados e, sobretudo, taxas altamente intensificadas de inovação comercial, tecnológica e organizacional. 
Em outras palavras, pode-se dizer que o regime de acumulação fordista esteve associado à segunda revolução tecnológica, à sociedade industrial, enquanto o regime de acumulação flexível está associado à terceira revolução tecnológica ora em curso, à sociedade pós-industrial ou sociedade do conhecimento.

Concordo com Hargreaves (2004, p. 34) quando afirma que a "economia do conhecimento não funciona a partir da força das máquinas, mas a partir da força do cérebro". Enquanto as economias industriais precisavam de trabalhadores para operar as máquinas e produzir bens materiais, a economia do conhecimento precisa cada vez mais de trabalhadores que manipulem informações e formas símbólicas para produzir conhecimentos, bens imateriais, que, claro, em grande medida impregnam bens materiais (a economia material continuará sendo a base das sociedades informacionais).

Esse é o aspecto central do que vem sendo chamado de sociedade do conhecimento. Entretanto, para merecer o substantivo "sociedade" que o precede, que é bem mais abrangente que "economia", falta ao conhecimento ser menos instrumentalizado e mais acessível à maioria das pessoas em cada uma das sociedades que compõem o sistema mundial, especialmente nas regiões mais carentes do planeta ou nas menos mimadas, para novamente parodiar Habermas (1993) ao revés. Ao longo deste trabalho, vou utilizar indistintamente os termos "conhecimento" ou "informacional" precedidos de "sociedade" ou "era", nunca de "economia".

De qualquer modo, essas transformações exigem mudanças imediatas, especialmente da perspectiva do sistema produtivo, na formação dos trabalhadorescidadãos. Por isso, nas mais recentes reformas educacionais, está tão em voga falar em competências, como veremos a seguir.

\section{Competências}

O discurso sobre competências está presente nas últimas reformas educativas em diversos países. No Brasil, foi trazido à baila pelas Diretrizes 
Curriculares Nacionais do Ensino Médio (DCNEM) e pelos Parâmetros Curriculares Nacionais do Ensino Médio (PCNEM) e, na Espanha, permeia a Ley Orgânica de Educación $(L O E)$, a última reforma feita naquele país.

Sobre esse fato, Perrenoud (1999, p. 12) indaga: "Por que será que vemos atualmente o que Romainville (1996) chama de uma 'irresistível ascensão' da noção de competência em educação escolar?"

O conceito de competência entrou na escola vindo do mundo do trabalho. Quanto a isso parece não haver dúvidas; resta saber o porquê disso. Para Machado (2002, p. 140): "Em uma sociedade na qual o conhecimento transformou-se no principal fator de produção, é natural que muitos conceitos transitem entre os universos da economia e da educação.". É certo que tem ocorrido esse trânsito, o problema é que a palavra "natural" pode mascarar as contradições e os interesses envolvidos nessa migração. Philippe Perrenoud, respondendo à pergunta feita acima, fala em "contágio":

\begin{abstract}
A explicação mais evidente consiste em invocar uma espécie de contágio: como o mundo do trabalho apropriou-se da noção de competência, a escola estaria seguindo seus passos, sob o pretexto de modernizar-se e de inserir-se na corrente dos valores da economia de mercado, como a gestão dos recursos humanos, busca da qualidade total, valorização da excelência, exigência de maior mobilidade dos trabalhadores e da organização do trabalho. (PERRENOUD, 1999, p. 12, grifo do autor).
\end{abstract}

Aqui, novamente, o problema é que a palavra "contágio" também tem uma conotação naturalizante e pode mascarar os sujeitos e esconder as intencionalidades subjacentes à ascensão da noção de competência no mundo da escola.

É mais plausível que o conceito tenha sido introduzido/incorporado no discurso escolar como uma tentativa de responder às novas necessidades da Economia, do sistema produtivo, mas também da Educação, do sistema escolar. Nesse sentido, concordo com Perrenoud quando afirma que: "Seria muito restritivo fazer do interesse do mundo escolar pelas competências o simples sinal de sua dependência em relação à política econômica. Há antes uma junção entre um movimento a partir de dentro e um apelo de fora." (1999, p. 14, grifo do autor). Entretanto, ao que parece, o "apelo de fora" é mais forte do que o "movimento de 
dentro". Tudo indica que são os interesses do sistema produtivo que, no fim das contas, determinam a disseminação do conceito de competência no sistema escolar. Ou seja, há uma hegemonia desse discurso que perpassa o sistema produtivo e acaba influenciando na adoção do conceito pelo sistema educativo.

O Relatório para a UNESCO da Comissão Internacional sobre Educação para o século XXI, lançado em 1996, corrobora a origem economicista do conceito de competência e identifica seu nascimento em um contexto de busca de adaptação tanto do sistema produtivo como do sistema educativo a uma realidade cambiante do ponto de vista econômico e tecnológico:

$\mathrm{Na}$ indústria especialmente para os operadores e os técnicos, o domínio do cognitivo e do informativo nos sistemas de produção torna um pouco obsoleta a noção de qualificação profissional e leva a que se dê muita importância à competência pessoal. O progresso técnico modifica, inevitavelmente, as qualificações exigidas pelos novos processos de produção. (DELORS, 2001, p. 93).

No trecho a seguir, do mesmo relatório, fica ainda mais evidente que a competência pessoal é uma exigência dos empregadores, a qual a escola tem de se adaptar na formação de seus alunos:

Os empregadores substituem, cada vez mais, a exigência de uma qualificação ainda muito ligada, a seu ver, à idéia de competência material, pela exigência de uma competência que se apresenta como uma espécie de coquetel individual, combinando a qualificação, em sentido estrito, adquirida pela formação técnica e profissional, o comportamento social, a aptidão para o trabalho em equipe, a capacidade de iniciativa, o gosto pelo risco.

Se juntarmos a estas novas exigências a busca de um compromisso pessoal do trabalhador, considerado como agente de mudança, torna-se evidente que as qualidades muito subjetivas, inatas ou adquiridas, muitas vezes denominadas "saberser" pelos dirigentes empresariais, se juntam ao saber e ao saber-fazer para compor a competência exigida - o que mostra bem a ligação que a educação deve manter, como aliás sublinhou a Comissão, entre os diversos aspectos da aprendizagem. (DELORS, 2001, p. 94).

A importância das competências na busca de adaptação a um mundo cambiante também fica evidente no texto introdutório às Diretrizes Curriculares Nacionais do Ensino Médio (DCNEM), aprovadas em 1998:

A facilidade de acessar, selecionar e processar informações está permitindo descobrir novas fronteiras do conhecimento, nas quais este se revela cada vez mais integrado. Integradas são também as competências e habilidades requeridas por uma 
organização da produção na qual a criatividade, autonomia e capacidade de solucionar problemas serão cada vez mais importantes, comparadas à repetição de tarefas rotineiras. (BRASIL, 2002a, p. 71).

O mesmo ocorre com a Ley Orgânica de Educación (LOE) na Espanha, que ainda relaciona a emergência das competências com a necessidade de aprendizagem permanente:

Fomentar el aprendizaje a lo largo de toda la vida implica, ate todo, proporcionar a los jóvenes una educación completa, que abarque los conocimientos y las competencias básicas que resultan necesarias en la sociedad actual, que les permita desarrollar los valores que sustentan la práctica de la ciudadanía democrática, la vida en común y la cohesión social, que estimule en ellos y ellas el deseo de seguir aprendiendo y la capacidad de aprender por sí mismos. (ESPAÑA, 2006a, p. 32).

A parte da $L O E$ que trata das competências, como veremos mais detalhadamente no capítulo 2 da parte II, foi inspirada no documento Proposta de recomendação do Parlamento Europeu e do Conselho sobre as competênciaschave para a aprendizagem ao longo da vida, elaborado por um grupo de trabalho designado pelo Conselho da União Européia. Esse documento, após listar as oito competências-chave para aprendizagem ao longo da vida, relativiza o economicismo embutido nesse conceito:

As competências são definidas aqui como uma combinação de conhecimento, aptidões e atitudes adequadas ao contexto. As competências-chave são aquelas de que todas as pessoas carecem para a realização e o desenvolvimento pessoais, para exercerem uma cidadania ativa, para a inclusão social e para o emprego. (COMISSÃO DAS COMUNIDADES EUROPÉIAS, 2005, p. 15).

Como veremos mais à frente, nas partes II e III, no Brasil o discurso sobre as competências e habilidades chega à escola por meio das DCNEM e dos PCNEM, mas a principal tentativa de sua operacionalização tem sido feita pelo Exame Nacional do Ensino Médio (ENEM), criado em 1998 pelo MEC. Veja como o ENEM: documento básico define competências e habilidades:

Competências são as modalidades estruturais da inteligência, ou melhor, ações e operações que utilizamos para estabelecer relações com e entre objetos, situações, fenômenos e pessoas que desejamos conhecer. As habilidades decorrem das competências adquiridas e referem-se ao plano imediato do "saber fazer". (INEP, 1998, p. 5, grifo do autor). 
Para Machado (2002), há um parentesco semântico entre os termos "competência" e "competição". Ambos originaram-se do verbo competir (com + petere), que em latim quer dizer "buscar junto com", "esforçar-se junto com". Apenas no latim tardio passou a prevalecer o sentido de "disputar junto com", no qual para um ganhar o outro tem de perder. De acordo com o Houaiss (2008), em sua primeira acepção, a palavra competição significa "concorrência a uma mesma pretensão por parte de duas ou mais pessoas ou grupos, com vistas a igualar ou especialmente a superar o outro". Sob a rubrica "economia" aparece como "luta ou rivalidade pela conquista de mercados". Já a palavra competência, com o sentido que vem ganhando no mercado de trabalho e no sistema educacional, pode ser encontrada sob a rubrica "psicologia": "capacidade objetiva de um indivíduo para resolver problemas, realizar atos definidos e circunscritos" (essa é décima acepção, a maioria das nove anteriores está no campo jurídico). De fato, Ramos (2002a) aponta a origem da noção de competência no campo da psicologia.

É interessante que, em espanhol, não há essa distinção existente em português. Segundo o dicionário da Real Academia Española (2008) a palavra "competencia" significa "pericia, aptitud, idoneidad para hacer algo o intervenir en un asunto determinado". Mas "competencia” também significa "oposición o rivalidad entre dos o más que aspiran a obtener la misma cosa" ou, num sentido econômico, "situación de empresas que rivalizan en un mercado ofreciendo o demandando un mismo producto o servicio". Os hispanohablantes até possuem a palavra “competición” em seu dicionário, porém é mais usada com o sentido de disputa esportiva.

Com base nas citações acima, pode-se dizer então que, em português, a competência pessoal está cada vez mais a serviço da competição econômica. Já em espanhol é a "competencia personal" a serviço da "competencia económica".

Entretanto, a definição do conceito de competência (no sentido pessoal do termo) tem maiores implicações, inclusive a necessidade de considerar o conceito de qualificação, para alguns seu antecessor. Aliás, Machado nos lembra que "as pessoas é que são ou não competentes, e toda tentativa de atribuição de competência a objetos ou artefatos parece insólita ou inadequada. A pessoalidade 


\section{é, pois, a primeira característica absolutamente fundamental da idéia de}

competência". (2002, p. 141, grifo do autor).

Celso Ferretti considera que a noção de competência "representa a atualização do conceito de qualificação, segundo as perspectivas do capital, tendo em vista adequá-lo às novas formas pelas quais este se organiza para obter maior e mais rápida valorização". (FERRETTI, 1997, p. 258 apud RAMOS, 2002a, p. 40). Gaudêncio Frigotto vê a noção de competência como uma atualização do conceito de capital humano. Falando sobre as mudanças que estão ocorrendo sob a égide da chamada sociedade do conhecimento, propõe que:

O primeiro desafio é, pois, de qualificar a base histórico-social das quais emergem essas novas exigências educativas e de formação humana - rejuvenescimento da teoria do capital humano - a de decifrar porque as teses de uma formação geral e abstrata, que prepara sujeitos polivalentes, flexíveis e participativos aparecem ao mesmo tempo com as perspectivas neoconservadoras de ajuste no campo econômico-social e no campo educacional mediante as leis de mercado. (FRIGOTTO, 2003, p. 56).

Aqui é preciso, mesmo que brevemente, rastrear a origem da concepção de capital humano, até porque ela influenciou diretamente as leis educacionais de 1970, na Espanha, e de 1971, no Brasil. Beltrán Duarte acredita que teoria do capital humano influenciou até mesmo as reformas educativas espanholas dos anos 1980 e 1990: "Pese a las duras críticas que se le han hecho, esta teoría sigue vigente." (2000, p 43).

A teoria do capital humano foi desenvolvida nos Estados Unidos, nos anos 1950, pelo grupo de estudos do desenvolvimento do Departamento de Economia da Universidade de Chicago, coordenado por Theodore W. Schultz (1902-1998), ganhador do prêmio Nobel de economia em 1979. Ele defendia que o investimento em capital humano, além dos tradicionais investimentos em capital não humano, daria uma contribuição maior para o aumento da capacidade de produção e da produtividade do trabalho. Em um artigo intitulado La inversión en capital humano, publicado originariamente em 1983, comentando a assistência aos países subdesenvolvidos para ajudá-los a crescer economicamente, Schultz (1999) destaca a importância de investir nos seres humanos para ampliar o desenvolvimento. Argumenta que, durante muito tempo, os países desenvolvidos, por meio do Banco 
Mundial e de outras agências de financiamento, "exportaram" doutrinas de crescimento assentadas exclusivamente em investimentos em capital não humano. Com a "exportação" dessas doutrinas, havia a exportação de máquinas e equipamentos, não acompanhadas, entretanto, de conhecimentos e habilidades. A carência de capital humano limitava o crescimento econômico. Em sua visão:

Algún crecimiento puede derivarse del incremento en el capital más convencional, incluso aunque el trabajo de que dispongan carezca de habilidad y conocimiento. Pero la tasa de crecimiento se verá seriamente limitada. Ciertamente, no es posible obtener los frutos de la agricultura moderna y la abundancia de la industria moderna sin hacer grandes inversiones en seres humanos. Verdaderamente, el rasgo más distintivo de nuestro sistema económico es el crecimiento en capital humano. (SCHULTZ, 1999, p. 95)

Beltrán Duarte (2000) argumenta que a teoria do capital humano tem sido criticada porque, se é certo que, em determinados momentos, a escola pode desempenhar um papel importante no desenvolvimento econômico e tecnológico, também é verdade que, em outros, o desenvolvimento pode ser produzido independentemente da modernização da escola - como na Espanha dos anos 1960 - e vice-versa. "Lo que hace pensar que ese desarrollo depende, además y muy directamente, de otros fatores que poco tienen que ver con las reformas educativas." (BELTRÁN DUARTE, 2000, p. 43).

Marise Ramos discorda dos dois enfoques anteriores e propõe que se encare o conceito de competência não como uma atualização da noção de qualificação ou da teoria do capital humano, mas como um "deslocamento conceitual". Para isso, segundo ela, é importante antes analisar o significado de qualificação, um conceito historicamente central na relação capital-trabalho.

[...] o conceito de qualificação, no que apresenta de mais objetivo, ordenou historicamente as relações sociais de trabalho e educativas, frente à materialidade do mundo produtivo. Essa centralidade tende a ser ocupada contemporaneamente, não mais pelo conceito de qualificação, mas pela noção de competência que, aos poucos constitui-se como um conceito socialmente concreto. Não obstante, a noção de competência não substitui ou supera o conceito de qualificação. Antes, ela o nega e o afirma simultaneamente, por negar algumas de suas dimensões e afirmar outras. (RAMOS, 2002a, p. 40-41).

O conceito de qualificação consolidou-se no pós-guerra como uma forma de regulação da relação capital-trabalho. Portanto, tem sua gênese associada ao 
regime de acumulação fordista-keynesiano. Qualificação servia para regular a inserção do trabalhador na relação capital-trabalho definindo padrões de formação, emprego, carreira e remuneração. De acordo com Ramos (2002a, p. 42), a qualificação está apoiada em dois sistemas: "a) as convenções coletivas, que classificam e hierarquizam os postos de trabalho; b) o ensino profissional, que classifica e organiza os saberes em torno de diplomas.". Para Perrenoud (1999, p. 12): "A noção de qualificação tem permitido por muito tempo pensar as exigências dos postos de trabalho e as disposições requeridas daqueles que os ocupam.". Qualificação, assim, ficou muito associada à idéia de profissão, de saberes formalizados e regulados por títulos e diplomas.

Ramos (2002a, 2002b), citando Schwartz (1995), argumenta que a qualificação apresenta três dimensões:

1) conceitual - associada aos conceitos teóricos, aos conhecimentos formalizados, relacionados aos títulos e diplomas;

2) social - situada no âmbito das relações sociais que se estabelecem entre as atividades e o reconhecimento social delas, das normas, dos códigos e dos direitos relativos ao exercício profissional;

3) experimental - relacionada ao conteúdo real do trabalho, formado não apenas pelo conhecimento teórico, formalizado, mas pelos saberes, incluindo os tácitos, postos em prática na realização do trabalho.

As dimensões conceitual (diplomas) e social (profissões) da qualificação se destacavam na época em que vigorava o fordismo, momento relativamente rígido do capitalismo, quando as mudanças eram lentas. Hoje, sob o regime acumulação flexível, período marcado por grande dinamismo e aceleradas transformações econômicas e tecnológicas, cada vez mais se destaca a dimensão experimental (saberes) da qualificação. É essa dimensão da qualificação, que ganha cada vez mais importância, ao lado das atitudes pessoais e articulada com a dimensão conceitual, que se chama de competência.

Para Schwartz (1990) a competência explica a nova articulação entre a dimensão experimental e a dimensão conceitual dos saberes necessários à ação. Com a competência, tomam lugar o saber-fazer proveniente da experiência, os registros provenientes da história individual ou coletiva dos trabalhadores, ao lado dos saberes 
mais teóricos tradicionalmente valorizados na lógica da qualificação. Enfim, fundamentada sobre a valorização da implicação subjetiva no conhecimento ela desloca a atenção para a atitude, o comportamento e os saberes tácitos dos trabalhadores. (RAMOS, 2002a, p. 66, grifo do autor).

Perrenoud (1999, p. 7) define competência como "uma capacidade de agir eficazmente em um determinado tipo de situação, apoiada em conhecimentos, mas sem limitar-se a eles". De fato, seja no mundo do trabalho ou no da escola, não dá para imaginar alguém competente sem dispor de nenhum conhecimento teórico. Machado (2002) chama de "terrível mal-entendido" a idéia muito difundida de que as competências concorrem com as disciplinas e completa que continuaremos a ter professores de disciplinas e que não tem cabimento falar em professor de "competências". O PCNEM chama atenção para isso ao afirmar que:

[...] as competências não eliminam os conteúdos, pois que não é possível desenvolvêlas no vazio. Elas apenas norteiam a seleção dos conteúdos, para que o professor tenha presente que o que importa na Educação Básica não é a quantidade de informações, mas a capacidade de lidar com elas, através de processos que impliquem sua apropriação e comunicação, e, principalmente, sua produção ou reconstrução, a fim de que sejam transpostas a situações novas. (BRASIL, 2002a, p. 289).

A adoção das competências nas recentes reformas educativas, tanto no Brasil como na Espanha, tem provocado muita discussão e uma polarização de opiniões. Nesse debate pode-se dizer que há:

a) educadores otimistas (incluindo evidentemente os envolvidos na elaboração dos documentos governamentais): entusiasmados com a noção de competências e crentes de que sua incorporação ao currículo escolar pode contribuir para a formação de trabalhadores e cidadãos mais preparados para enfrentar o dinâmico mundo em que vivemos;

b) educadores céticos: vêem a adoção da noção de competências no mundo da escola apenas como uma adaptação do sistema educativo ao sistema produtivo, como uma instrumentalização da Educação pela Economia, pelos interesses do capital.

Esse debate é importante e será aprofundado mais à frente com exemplos concretos. 


\section{As reformas educacionais, a sociedade do conhecimento e o currículo}

A informação e especialmente o conhecimento transformaram-se numa questão estratégica no mundo de hoje. O conhecimento é o principal recurso da sociedade informacional e por isso é motivo de embates na definição de quais conteúdos culturais serão ensinados nas escolas, de onde emerge a importância do currículo. No entanto, isso já vem de longa data. Postman (1994) afirma que, em 1480, antes da explosão da informação pós-Gutenberg, havia 34 escolas em toda a Inglaterra; por volta de 1660, já havia 444. Credita esse crescimento, entre outros fatores, especialmente à necessidade de dar respostas às ansiedades e confusões causadas pela informação desenfreada. Para esse teórico da comunicação:

A invenção do que é chamado de currículo foi o passo lógico para organizar, limitar e discriminar as fontes de informação disponível. As escolas tornaram-se as primeiras burocracias seculares da tecnocracia, estruturas para legitimar algumas partes do fluxo de informações e para desacreditar outras. Resumindo, as escolas eram um meio de governar a ecologia da informação (POSTMAN, 1994, p. 71).

Esse papel do currículo não mudou hoje em dia; ao contrário, só se acentuou. Ao elaborar a resposta para a pergunta "De quem é o conhecimento de maior valor?", Apple (2006, p. 21) chama a atenção para o fato de que há "uma imensa pressão para que o sistema educacional de muitos países torne os objetivos da área de negócios e da indústria seus próprios objetivos fundamentais ou únicos". Evidentemente que ele está pensando em "valor" no sentido econômico. Gaudêncio Frigotto, no prefácio que escreveu para o livro $A$ pedagogia das competências: autonomia ou adaptação?, de Marise Nogueira Ramos, depois de criticar a adoção da pedagogia das competências na reforma do ensino médio, adotada pelos PCNEM e ENEM, afirma:

Cada indivíduo terá de agora em diante, então, de adquirir um banco ou pacote de competências desejadas pelos homens de negócio no mercado empresarial, permanentemente renováveis, cuja certificação the promete empregabilidade. (RAMOS, 2002a, p. 16). 
Beltrán Duarte lista uma série de declarações - de documentos do governo do PSOE (Programa 2000, feito em 1990), da OCDE, de dirigentes empresariais - propondo que a escola espanhola dê respostas às necessidades do desenvolvimento econômico e tecnológico do país. Em seguida acrescenta: "Ante declaraciones de esta naturaleza, podría pensarse que la única, o principal, función de la escuela consiste en preparar a los indivíduos para adaptarse a las exigencias del mercado de trabajo." (BELTRÁN DUARTE, 2000, p. 42).

Enfim, esses autores nos alertam para a crescente instrumentalização da Educação pelo sistema produtivo. Para atender às injunções do mercado está havendo, aparentemente, em todos sistemas educativos um crescimento do peso da razão instrumental em detrimento da razão comunicativa.

José Gimeno Sacristán nos lembra que o currículo é uma opção cultural, é cultura-conteúdo do sistema educativo. O teórico espanhol define o currículo como "o projeto seletivo de cultura, cultural, social, política e administrativamente condicionado, que preenche a atividade escolar e que se torna realidade dentro das condições da escola tal como se acha configurada". (GIMENO SACRISTÁN, 2000, p. 34).

Com isso, podemos considerar as reformas curriculares projetos eminentemente ideológicos ${ }^{34}$ que têm como objetivo referendar determinados conhecimentos (e não outros) no sistema educativo, visando a criar e sustentar relações de poder na sociedade informacional. Para Apple (2006, p. 50), a Educação "deve ser vista como uma seleção e organização de todo o conhecimento social disponível em uma determinada época". Depois de afirmar isso, chama a atenção para o fato de que o conhecimento curricular não é neutro. Aqui comete um pequeno deslize lógico: se o currículo é uma seleção de conhecimentos, logo não pode ser de "todo" o conhecimento social disponível em uma determinada época: há inclusões e exclusões. A questão é: o que entra e o que não entra? Voltamos à questão do conhecimento de maior valor colocada por Apple (2006), da qual se desdobra outra: "maior valor" para quem? O que nos remete de novo ao currículo como uma seleção

34 Conforme ideologia foi definida neste trabalho, como uma tentativa de atribuição de sentido a formas simbólicas na criação e sustentação de relações de dominação (Thompson, 2000). 
cultural - e ideológica - de conhecimentos. Em outras palavras, o currículo nunca é neutro.

Aqui os conceitos de comunidade epistêmica (LOPES, 2006) e campo disciplinar (MORAES, 2000) se complementam e são úteis para estabelecer a relação entre poder e conhecimento, portanto para compreender como é feita a seleção dos aspectos da cultura que entrarão no currículo.

Para Lopes (2006), o conceito de comunidade epistêmica permite compreender as influências exercidas sobre o Estado por grupos de especialistas, não apenas cientistas, mas também políticos, empresários, profissionais liberais etc. Em suas palavras:

O que distingue as comunidades epistêmicas de outros agentes sociais é o fato de serem constituídas por uma rede de profissionais com perícia e competência reconhecidas em um domínio particular, ao mesmo tempo que reivindicam uma autoridade política relevante em função do domínio que exercem em sua área específica de conhecimento. (ANTONIADES, 2003 apud LOPES, 2006, p. 145).

Campo disciplinar, para Moraes (2000, p. 7), é "a resultante de uma tradição acadêmica com um quadro conceitual próprio, articulada por determinadas filiações teóricas que fornecem seu eixo de estruturação".

Uma comunidade epistêmica pode ter uma influência internacional, como, por exemplo, a equipe que elaborou o Relatório para a UNESCO (DELORS, 2001), ou nacional, como é o caso dos elaboradores dos Parâmetros Curriculares Nacionais do Ensino Médio (PCNEM) (BRASIL, 2002b) ou das últimas "enseñanzas mínimas" (currículo mínimo) para a educação secundária espanhola (ESPAÑA, 2007a, 2007b).

Grupos de um campo disciplinar podem ter interesse em difundir determinados conhecimentos, determinadas visões de mundo e concepções teóricometodológicas, muitas vezes conflitantes com o que pregam outros grupos do mesmo campo disciplinar. Isso fica patente quando se analisam os documentos das reformas curriculares, como veremos na parte III, especialmente no capítulo 1.

Krüger (2006), ao discutir o conceito de "sociedade do conhecimento", após argumentar que se trata de um termo com grande destaque na discussão atual das ciências sociais, assim como na política européia, afirma: 
Se trata de un concepto que aparentemente resume las transformaciones sociales que se están produciendo en la sociedad moderna y sirve para el análisis de estas transformaciones. Al mismo tiempo, ofrece una visión del futuro para guiar normativamente las acciones políticas.

De fato, como será tratado no capítulo 2 da parte II, a lei que orienta a atual reforma espanhola, a Ley Orgânica de Educación (LOE), menciona a necessidade de adequação para se viver na "nueva sociedad del conocimiento" (ESPAÑA, 2006a). O PCNEM brasileiro, como veremos no capítulo 1 da parte II, fala em adaptação às mudanças provocadas ora pela "revolução da informática", ora pela "revolução do conhecimento" (BRASIL, 2002a).

Ou seja, as comunidades epistêmicas encarregadas de elaborar os documentos da reforma educacional em cada país, para justificá-la, lançam mão dos conceitos de "sociedade do conhecimento" (e suas variantes), assim como do de "competências", como aparece nas "enseñanzas mínimas" (ESPAÑA, 2007a) e nas Orientações Curriculares para o Ensino Médio (BRASIL, 2006). Esses conceitos apreendem muito da mudança social do mundo atual e de suas novas demandas, mas também têm muito de prescrição ideológica. Para serem heurísticos, é importante desvendar as ideologias que os perpessam. 


\section{Parte II}

A reforma estrutural no Brasil e na Espanha: ensino MÉDIO 


\section{O SISTEMA EDUCACIONAL BRASILEIRO E AS MUDANÇAS NO ENSINO MÉDIO}

No Brasil, embora a abertura política possa ser situada em 1985, foi a aprovação da Constituição de 1988 o marco fundamental da transição da ditadura militar para a atual democracia. A nova lei máxima é a referência para a elaboração da Lei de Diretrizes e Bases da Educação Nacional n. 9394 de 1996 e a legislação complementar que orienta até hoje as mudanças na educação brasileira. O sistema de ensino brasileiro atualmente é ordenado pela LDB 9394/96, entretanto, para compreender sua organização e seu funcionamento é necessária uma breve retomada da legislação anterior, a Lei de Diretrizes e Bases para o ensino de $1^{\circ}$ e $2^{\circ}$ graus n. 5692 de 1971, mais conhecida como LDB 5692/71. Isso é importante também para a compreensão das mudanças políticas, sociais e econômicas que ocorreram no país nesses trinta e poucos anos, além do contexto em que cada uma dessas leis foi elaborada. Enfim, não dá para compreender o texto sem o contexto.

Nessa retomada serão enfatizadas as mudanças estruturais e curriculares, especialmente as ocorridas no ensino médio.

\section{Antecedentes: a LDB 5692/71}

O primeiro projeto de lei para a criação de uma ordenação geral da educação brasileira foi apresentado ao Congresso em 1948, portanto, 13 anos antes da aprovação do que seria a LDB 4024/61. As infindáveis discussões, a ausência de acordo, o conflito de interesses econômico-ideológicos, especialmente entre os defensores da escola pública e os interesses da rede privada ${ }^{35}$, explicam tão longa maturação dessa lei. Entretanto, a análise desse processo foge ao escopo desta pesquisa. Devido a essa longa maturação e à desvinculação da Educação com o processo de industrialização e com o crescimento do país, essa nova lei já nasceu

35 Nessa época as escolas privadas eram em sua maioria pertencentes a congregações católicas. A Igreja Católica era a principal defensora da iniciativa privada (SAVIANI, 2006). 
defasada (PIMENTA; GONÇALVES, 1992). Para Saviani (2006, p. 40) muitos a criticavam porque suas propostas "não davam atenção à vinculação da educação ao desenvolvimento brasileiro".

A LDB chegou a ser arquivada e somente em 1958 foi reapresentada por meio de um substitutivo do deputado Carlos Lacerda, da União Democrática Nacional (UDN). A lei finalmente aprovada três anos depois, manteve praticamente a mesma estrutura do sistema de ensino já existente: pré-primário, primário, médio e superior. O ensino médio era dividido em dois ciclos: ginasial (4 séries) e colegial (3 séries). O colegial, por sua vez, mantendo a estrutura dual criada pela Lei Orgânica do Ensino Secundário de 1942, era dividido em: secundário (com menos matérias, agora distribuídas em obrigatórias e optativas) e técnico (industrial, comercial, agrícola e normal). Entretanto, apesar da manutenção das duas redes, houve um importante avanço: a LDB 4024/61 estabeleceu a equivalência entre o ensino secundário e o ensino técnico. Até então quem "optasse" pelo técnico não poderia ir para a universidade. Com isso, o aluno que concluísse um ou outro itinerário poderia pleitear uma vaga no ensino superior. Formalmente, pelo menos, acabara a estrutura dual que vigorara até então.

A Lei 4024/61 foi gestada num período relativamente democrático no qual os "partidos ideológicos"36, representados no Congresso Nacional por meio dos partidos políticos, tinham de negociar e expor seus interesses conflitantes. De um lado, na oposição, estava a União Democrática Nacional (UDN), representando os interesses dos setores empresariais (financeiro e industrial), especialmente os ligados ao capital estrangeiro, profissionais liberais e setores das classes médias urbanas, e do outro, na situação, e com todo o legado varguista, o Partido Social Democrático (PSD) e o Partido Trabalhista Brasileiro (PTB). O primeiro representava os interesses dos industriais nacionais, os proprietários de terras e a burocracia estatal, e o segundo, baseado fortemente no operariado urbano, especialmente os

36 Gramsci define partido ideológico como "o partido como ideologia geral, superior aos vários agrupamentos mais imediatos”. (GRAMSCI, 1975, vol. 2, p. 1353 e 1977a, p. 221 apud SAVIANI, 2006, p. 4). Com base nisso, Saviani (2006, p. 4) afirma que "sob o conceito de 'partido ideológico' se agrupa o conjunto dos aparelhos e organizações intelectuais, tais como a imprensa, as editoras, círculos, clubes, igrejas, associações culturais, profissionais ou comunitárias, entidades de benemerência, as escolas públicas e privadas de diferentes tipos e níveis etc.”. Faltou ser mais explícito quanto às organizações empresariais, que hoje são os "partidos ideológicos" mais poderosos do país. 
setores organizados por lideranças cooptadas pelo varguismo (PIMENTA; GONÇALVES, 1992).

De acordo com Saviani (2006) os partidos, sejam eles políticos ou ideológicos, buscam atingir seus objetivos por meio de determinadas estratégias de ação. Nesse período, segundo ele, vigorou a "estratégia da conciliação" sob um regime de "democracia restrita". ${ }^{37}$

Embora tenha prevalecido a conciliação, como essa foi pelo alto, a lei expressava as contradições de uma sociedade profundamente desigual, na qual a democracia era formal e o desenvolvimento econômico-social limitado a poucos.

Com o passar do tempo o PSD foi se afastando do PTB e acabou fazendo aliança com a UDN na eleição de Jânio Quadros. Essa aproximação de interesses dos setores conservadores da sociedade levou-os a apoiar o golpe militar de 1964, sob o qual ocorreram as mudanças mais significativas do sistema de ensino brasileiro. Sob a ditadura militar foi aprovada a Lei 5692/71, responsável pela ordenação do sistema de ensino brasileiro até a aprovação de 9394/96, já sob a democracia.

A Lei 5692/71, elaborada para fixar as Diretrizes e Bases para o Ensino de $1^{\circ}$ e $2^{\circ}$ graus, teve uma trajetória bem diferente de sua antecessora, a 4024/61. Desde o início da atividade do Grupo de Trabalho, criado pelo então presidente Emílio Garrastazu Médici em maio de 1970, até a aprovação da lei no Congresso, em dezembro de 1971, passou-se pouco mais de um ano e meio. Esses tempos diferentes para a tramitação das duas leis devem-se aos diferentes contextos políticos em que foram gestadas.

A LDB 5692/71 foi gestada sob a ditadura militar, num regime de "democracia excludente"38, para continuar utilizando os termos de Dermeval Saviani.

Então, por que ele não usou ditadura, o termo apropriado para se referir àquele regime? Saviani justifica dizendo que preferiu a expressão "democracia

\footnotetext{
37 "Por 'democracia restrita' estamos entendendo o regime que mantém abertas as franquias democráticas cujos canais de participação, entretanto, só são alcançados por uma determinada e restrita parcela da sociedade, parcela essa constituída pelas chamadas elites, seja do ponto de vista socioeconômico, seja do ponto de vista cultural." (SAVIANI, 2006, p. 7-8).

38 "Por 'democracia excludente' estamos compreendendo um regime que deliberada e sistematicamente exclui da participação política amplos setores da sociedade civil, entre eles as chamadas 'elites dirigentes'. Obviamente 'democracia excludente' é eufemismo de 'ditadura'.” (SAVIANI, 2006, p. 8).
} 
excludente" porque o regime implantado com o golpe militar de 1964 se definia como democrático e a própria tomada do poder foi urdida com a justificativa de salvar a democracia. O Congresso continuou funcionando, havia eleições formais, era o que o coronel Jarbas Passarinho, ministro da Educação do governo do general Emílio Garrastazu Médici (1969-1974), chamava de "ditadura envergonhada":

Porque ficou aberto o Congresso, as eleições foram realizadas dentro do prazo, a cada eleição a Arena perdia mais. A outra, de Getúlio (Vargas), acabou com o Congresso e até concurso de miss não se podia chamar de eleição, que era uma palavra proibida. (PASSARINHO, 2002).

Saviani (2006, p. 8) corrobora isso ao afirmar que sob o Estado Novo os dirigentes "não se pejavam de utilizar o termo 'ditadura' para denominar o regime por eles implementado e exaltado".

No momento histórico em que ocorreu o golpe militar de 1964, o Brasil estava situado no chamado mundo ocidental, na zona de influência dos Estados Unidos, e se viu enredado nas disputas geopolítico-ideológicas da Guerra Fria. Nesse contexto, o comunismo era visto como uma ameaça à democracia e o combate ao sistema político-econômico, difundido pela então União Soviética, justificou ideologicamente não apenas o regime militar brasileiro, mas todos os outros implantados na América Latina na mesma época.

Assim como Ramos (2005), prefiro a expressão "golpe civil-militar" para definir o movimento que provocou uma ruptura política no país em 1964. Isso porque setores importantes da sociedade civil apoiaram o golpe e participaram da ditadura que a ele se seguiu. Ou talvez fosse mais adequado ainda falar em "golpe militarcivil”, já que o protagonismo foi dos militares de alta patente, e, conseqüentemente, em ditadura militar-civil. Embora houvesse civis no governo, os principais dirigentes, a começar pelo presidente da República - sempre um general - eram militares.

Com a sociedade amordaçada, com a oposição presa, morta ou exilada, não havia com quem debater a nova lei. Como veremos, mesmo o partido político de oposição consentida, o Movimento Democrático Brasileiro (MDB), ficou marginalizado. Assim, restou ao Congresso e à "oposição" apenas legitimar o projeto de lei encaminhado pelo Poder Executivo. 
A responsabilidade pela designação dos membros do Grupo de Trabalho que iria elaborar o anteprojeto da reforma coube a Jarbas Passarinho, ministro da Educação do governo Médici.

O Grupo de Trabalho ${ }^{39}$ iniciou suas atividades em 6 de junho de 1970, com a incumbência de concluir seu relatório num prazo de 60 dias. Em agosto o Grupo encaminhou o relatório juntamente com um anteprojeto de lei da reforma ao ministro da Educação. De posse desses documentos o ministro os submeteu à apreciação do Conselho Federal de Educação, que agregou emendas ao anteprojeto. O texto resultante transformou-se no projeto de lei que em de março de 1971 foi encaminhado pelo ministro Jarbas Passarinho ao presidente Garrastazu Médici. Em junho de 1971 o presidente encaminhou esse projeto ao Congresso para ser apreciado em "regime de urgência" na Câmara dos Deputados e no Senado. Os deputados e senadores tinham um prazo de 40 dias para apreciação e deliberação, caso contrário, o projeto de lei seria aprovado por decurso de prazo.

No dia 19 de junho foi aberta a sessão conjunta encarregada de designar a Comissão Mista que ficaria responsável pelo estudo do projeto de lei enviado pelo presidente, pela avaliação das emendas a serem feitas pelos parlamentares das duas casas e pela elaboração de um parecer a ser apresentado um mês depois. Essa Comissão foi composta por vinte e dois parlamentares: dez senadores e oito deputados da Aliança Renovadora Nacional (ARENA), partido de sustentação do regime, e um senador e três deputados do $\mathrm{MDB}$, a oposição consentida. A votação deveria acontecer até o dia 8 de agosto, data limite para expirar o prazo de 40 dias fixado pelo dispositivo do "regime de urgência".

Depois de rápida tramitação de toda a matéria - o projeto, as emendas e o substitutivo do relator Aderbal Jurema (Arena-PE) - entraram em discussão em turno único. Aberta a sessão, apenas quatro oradores falaram e apenas dois destaques sem importância foram apresentados, mas rejeitados. Dessa forma célere, quase sem discussão, foi aprovado em 27 de julho, em sessão conjunta no Congresso Nacional, o substitutivo que deu origem à Lei que fixa as Diretrizes e

39 Era composto pelo padre José de Vasconcelos, representante da Igreja Católica, como presidente; Valnir Chagas, professor da Universidade de Brasília e membro do Conselho Federal de Educação, como relator; e mais sete membros, entre as quais o deputado Aderbal Jurema (ARENA-PE), que depois seria relator do projeto de lei que redundaria na LDB 5692/71 (SAVIANI, 2006). 
Bases para o Ensino de $1^{\circ}$ e $2^{\circ}$ graus. Em 11 de agosto de 1971 a Lei n. 5692 foi sancionada pelo presidente da República Emílio Garrastazu Médici.

Achei por bem fazer um breve resumo da tramitação da Lei 5692/71 ${ }^{40}$, para destacar quão veloz foi todo o processo, bem diferente do que ocorreu com a tramitação da Lei 4024/61, que se arrastou por longos 13 anos. Isso evidencia que sob a ditadura militar-civil instaurada em 1964 havia uma total submissão do Poder Legislativo ao Poder Executivo e a completa ausência de oposição, tanto no Congresso como na sociedade. Essa situação é típica de um regime de "democracia excludente" que operava com base na estratégia do "autoritarismo triunfante", no dizer de Saviani (2006). Era a época do "milagre econômico", do projeto "Brasil potência" e de bordões como "ninguém segura este país" e "ame-o ou deixe-o".

Como afirmam diversos autores (SAVIANI, 2006; PIMENTA; GONÇALVES, 1992) a ruptura política, o golpe militar-civil, deu-se exatamente para garantir a continuidade da ordem socioeconômica, marcada pelo desenvolvimento socialmente excludente, dependente e associado ao capital internacional. Aqui se pode falar também de "reforma reformista", como dizia Lerena (1999), porque a chamada "revolução de 64" foi um movimento urdido para conservar as relações de poder e de propriedade, não para modificá-las.

A Lei de Diretrizes e Bases para o ensino de $1^{\circ}$ e $2^{\circ}$ graus é uma lei tecnicista e com viés fortemente centralista e autoritário, especialmente no que tange ao ensino de $2^{\circ}$ grau. É compreensível que assim o seja já que foi criada para dar respostas ao modelo político-econômico vigente na época. Nesse sentido, há um claro paralelismo entre a LDB 5692/71 e a Ley General de Educación (LGE), elaborada em 1970 sob a ditadura de Francisco Franco, como analisaremos a seguir. Ambas são tecnicistas, gestadas no mesmo momento do capitalismo período da segunda revolução industrial, do regime de acumulação fordista (HARVEY, 1993) -, portanto, em linhas gerais, dão respostas às mesmas demandas políticas e econômicas. Vale parafrasear para a LDB o que Carlos Lerena disse para a LGE: segundo ele, essa lei teria promovido um "reforzamiento de la ideología economicista y tecnicista acerca de las funciones sociales del sistema de

${ }_{40}$ O detalhamento desse processo foge ao escopo desta pesquisa, mas pode ser visto em Saviani (2006). 
enseñanza, en virtud de la cual se concibe a este como una empresa de producción, ante la que se reclama rendimiento y eficacia técnica". (LERENA, 1999, p. 717). A lei brasileira também serviu para um reforço da ideologia economicista e tecnicista sobre as funções sociais do sistema de ensino, em virtude disto este passa a ser concebido como uma empresa de produção.

Deve ser lembrado, no entanto, que as próprias diretrizes, as orientações da Educação Nacional, permaneceram as mesmas da 4024/61, já que foram mantidos os cinco primeiros títulos daquela lei: I - Dos fins da educação; II - Do direito à educação; III - Da liberdade do ensino; IV - Da administração do ensino e IV - Dos sistemas de ensino (deste título os artigos 18 e 21 foram revogados pela 5692/71). Assim, a lei 5692/71 foi o embasamento legal para uma reforma de caráter mais estrutural e curricular.

A principal mudança que ela impôs foi estrutural: extinguiu o exame de admissão ${ }^{41}$ para o ginásio e fundiu esse ciclo com o primário, criando um ciclo único de oito anos, o $1^{\circ}$ grau. Na educação média aconteceram as mudanças mais polêmicas. Desaparecem os dois itinerários do colégio: o antigo secundário, de caráter propedêutico, e o antigo técnico. No lugar deles foi criado um único curso, o $2^{\circ}$ grau, de caráter exclusivamente profissionalizante.

O ensino de $1^{\circ}$ e $2^{\circ}$ graus passou a ter um núcleo comum de matérias obrigatórias em todo o território brasileiro, com o objetivo garantir a "unidade nacional", complementado com uma parte diversificada, que no caso do $2^{\circ}$ grau era composta por matérias profissionalizantes, conforme reza o artigo $4^{\circ}$, parágrafo $3^{\circ}$ :

Art. $4^{\circ}$ Os currículos do ensino de $1^{\circ}$ e $2^{\circ}$ graus terão um núcleo comum, obrigatório em âmbito nacional, e uma parte diversificada para atender, conforme as necessidades e possibilidades concretas, às peculiaridades locais, aos planos dos estabelecimentos e às diferenças individuais dos alunos.

$[\ldots]$

$\S 3^{\circ}$ Para o ensino de $2^{\circ}$ grau, o Conselho Federal de Educação fixará, além do núcleo comum, o mínimo a ser exigido em cada habilitação profissional ou conjunto de habilitações afins. (BRASIL, 1971).

O quadro 3 mostra as matérias do núcleo comum:

41 Quem não passasse nesse exame ao final do primário, era obrigado a fazer um ano de preparação antes de ir para o ginásio. 


\begin{tabular}{|l|l|l|l|}
\hline \multicolumn{3}{|c|}{ Quadro 3. Matérias do núcleo comum da LDB 5692/71 } \\
\hline Matérias & Atividades & Áreas de Estudo & Disciplinas* \\
\hline $\begin{array}{l}\text { Comunicação e } \\
\text { Expressão }\end{array}$ & $\begin{array}{l}\text { Comunicação e } \\
\text { Expressão }\end{array}$ & $\begin{array}{l}\text { Comunicação em } \\
\text { Língua Portuguesa } \\
\text { Língua estrangeira }\end{array}$ & $\begin{array}{l}\text { Língua Portuguesa } \\
\text { Literatura Brasileira } \\
\text { Língua estrangeira }\end{array}$ \\
\hline Estudos Sociais & Integração Social & $\begin{array}{l}\text { Estudos Sociais } \\
\text { OSPB* }\end{array}$ & $\begin{array}{l}\text { História } \\
\text { Geografia } \\
\text { OSPB }\end{array}$ \\
\hline Ciências & $\begin{array}{l}\text { Iniciação às } \\
\text { Ciências (inclusive } \\
\text { Matemática) }\end{array}$ & $\begin{array}{l}\text { Matemática } \\
\text { Ciências }\end{array}$ & $\begin{array}{l}\text { Matemática } \\
\text { Ciências Físicas e } \\
\text { Biológicas }\end{array}$ \\
\hline $\begin{array}{l}\text { (art. 7º Educação Moral e Cívica, Educação Física, Educação Artística, Programa de } \\
\text { Saúde e Ensino Religioso }\end{array}$
\end{tabular}

Fonte: Pimenta e Gonçalves (1992, p. 53).

* Filosofia, que constava da estrutura curricular da 4024/61, foi retirada da área de Estudos Sociais na reforma implementada pela LDB 5692/71. Os conteúdos a serem desenvolvidos em cada uma dessas disciplinas eram definidos pelos Guias Curriculares elaborados pelas Secretarias de Educação dos Estados. **Organização Social e Política Brasileira.

Buscando dar respostas às necessidades de mão-de-obra qualificada para sustentar o desenvolvimento industrial, a lei 5692/71 implantou a profissionalização compulsória no ensino de $2^{\circ}$ grau. Veja o que diz os parágrafos $1^{\circ}$ e $2^{\circ}$ do artigo $5^{\circ}$ :

$\S 1^{\circ}$ Observadas as normas de cada sistema de ensino, o currículo pleno terá uma parte de educação geral e outra de formação especial, sendo organizado de modo que:

a) no ensino de primeiro grau, a parte de educação geral seja exclusiva nas séries iniciais e predominante nas finais;

b) no ensino de segundo grau, predomine a parte de formação especial.

$\S 2^{\circ}$ A parte de formação especial do currículo:

a) terá o objetivo de sondagem de aptidões e iniciação para o trabalho, no ensino de $1^{\circ} \mathrm{grau}$, e de habilitação profissional, no ensino de $2^{\circ}$ grau.

b) será fixada, quando se destina a iniciação e habilitação profissional, em consonância com as necessidades do mercado de trabalho local ou regional, à vista de levantamentos periodicamente renovados. (BRASIL, 1971).

O parágrafo $3^{\circ}$ do mesmo artigo abre uma tênue brecha para a educação geral no ensino de $2^{\circ}$ grau, mas como exceção: 
$\S 3^{\circ}$ Excepcionalmente, a parte especial do currículo poderá assumir, no ensino de $2^{\circ}$ grau, o caráter de aprofundamento em determinada ordem de estudos gerais, para atender a aptidão específica do estudante, por indicação de professores e orientadores. (BRASIL, 1971).

Diversos autores, como Gaudêncio Frigotto e Marise Ramos, interpretam a profissionalização compulsória como resultado da aplicação da teoria do capital humano. "O conjunto de postulados básicos da teoria do capital humano teve profunda influência nos (des)caminhos da concepção, políticas e práticas educativas no Brasil, sobretudo, na fase mais dura do golpe militar de 64, anos 1968 a 1975." (FRIGOTTO, 2003, p. 43). "Esse é o período em que a teoria do capital humano é mais difundida e que tomam força os princípios da economia da educação." (RAMOS, 2005, p. 234). Frigotto (2003, p. 41) ainda acrescenta:

A disseminação da "teoria" do capital humano, como panacéia da solução das desigualdades entre países desenvolvidos e subdesenvolvidos e entre os indivíduos, foi rápida nos países latino-americanos e de Terceiro Mundo, mediante os organismos internacionais (BID, BIRD, OIT, UNESCO, FMI, USAID, UNICEF) e regionais (CEPAL, CINTERFOR), que representam dominantemente a visão e os interesses do capitalismo integrado ao grande capital.

De fato, foi marcante a influência da USAID (Agência dos Estados Unidos para o Desenvolvimento Internacional) na reforma educacional brasileira de 1971.

Entretanto, como a vida é dialética, contrariando a pretensão tecnicista e planificadora do regime, a profissionalização compulsória fracassou por diversos motivos e também não resolveu a antiga dualidade do ensino secundário. Como nos lembra Saviani (2004), o Relatório do Grupo de Trabalho responsável pela redação inicial da 5692/71, critica o dualismo existente antes dessa lei e para isso utiliza a seguinte frase para se referir ao modelo herdado da 4024/61: "ensino secundário para nossos filhos e ensino profissional para os filhos dos outros". Com isso os elaboradores do documento queriam dizer que a elite reservava aos seus filhos 0 itinerário preparatório para o ensino superior, voltado à formação de dirigentes, e ao restante da população, o itinerário profissionalizante, voltado à formação de trabalhadores subalternos. A adoção da profissionalização universal e compulsória do ensino de segundo grau foi justificada como uma contraposição a isso, como uma solução para essa dualidade. Entretanto, na prática, a dualidade continuou existindo 
porque a lei, segundo Saviani (2004), introduziu a distinção entre terminalidade real e terminalidade ideal. Essa corresponde à conclusão do $1^{\circ}$ e $2^{\circ}$ graus após 0 cumprimento 11 anos de escolaridade; aquela, à antecipação da formação profissional como meio de garantir a todos, mesmo àqueles que não concluíram o $1^{\circ}$ grau, um preparo mínimo para entrar no mercado de trabalho. Portanto, a terminalidade real é bem menor do que a ideal que consta na lei. De acordo com Saviani (2004, p. 7): "Com isso a diferenciação e o tratamento desigual foram mantidos no próprio texto da lei, apenas convertendo o slogan anterior neste outro: 'terminalidade legal para nossos filhos e terminalidade real para os filhos dos outros'.".

Além disso, essa reforma chocou-se com o projeto de ascensão social da classe média, que rejeitou a função contenedora do ensino técnico rumo à universidade (RAMOS, 2005). Nas palavras de Pinto (2007, p. 50):

Tudo indica que o objetivo por trás deste novo desenho do ensino médio, dando-lhe um caráter de terminalidade dos estudos, foi o de reduzir a demanda para o ensino superior e tentar aplacar o ímpeto das manifestações estudantis que exigiam mais vagas nas universidades públicas.

A escola privada resistiu à implantação da profissionalização, seja pelos investimentos que teria de fazer, seja pela resistência da clientela, interessada unicamente em ir para o ensino superior (PIMENTA; GONÇALVES, 1992). Ou seja, o ensino privado continuou tendo um caráter propedêutico. O máximo que as escolas privadas fizeram foi criar a profissionalização "faz-de-conta" (PINTO, 2007), por meio da qual os alunos faziam algumas disciplinas técnicas e obtinham qualificação, por exemplo, de técnico de análises clínicas para os que pretendiam fazer curso superior de medicina. Já no ensino público, a insuficiência de recursos também inviabilizou a profissionalização compulsória. Entretanto, a maior contradição, visível até hoje nas escolas técnicas federais, foi a crescente função propedêutica do próprio ensino técnico. Como diz Ramos (2005, p. 233): "O ensino técnico, realmente, assumiu uma função manifesta e outra não manifesta. A primeira, a de formar técnicos; a segunda, de formar candidatos para os cursos superiores.". 
Além disso, como nos lembram Pimenta e Gonçalves (1992, p. 51), "o parque industrial, especialmente as empresas estrangeiras, precisava de mão-deobra barata, mais do que dos técnicos qualificados que poderiam emergir da profissionalização do ensino de $2^{\circ}$ grau". Pinto (2007, p. 50) chama a atenção para o mesmo problema quando argumenta que "as empresas preferiam qualificar internamente seu pessoal do que contratar técnicos por salários mais altos e mais exigentes quanto às condições de trabalho". De fato, sob a vigência do fordismo, que exigia um trabalhador mais adestrado do que qualificado, milhares de pessoas que não tinham concluído nem mesmo o antigo primário vinham migrando do campo para a cidade. De um dia para outro, agricultores metamorfoseavam-se em operários. Apresentavam baixo grau de qualificação, portanto, eram mal remunerados, embora em geral menos mal do que quando trabalhavam no campo, onde as condições de vida eram piores.

Como conseqüência de todas essas contradições, a Lei n. 7044 de 18 de outubro de 1982 extinguiu a profissionalização compulsória, como fica evidente pelos termos do parágrafo $2^{\circ}$ do artigo $4^{\circ}$ :

Art. $4^{\circ}$ - Os currículos do ensino de $1^{\circ}$ e $2^{\circ}$ graus terão um núcleo comum, obrigatório em âmbito nacional, e uma parte diversificada para atender, conforme as necessidades e possibilidades concretas, às peculiaridades locais, aos planos dos estabelecimentos de ensino e às diferenças individuais dos alunos.

$\S 1^{\circ}$ - A preparação para o trabalho, como elemento de formação integral do aluno, será obrigatória no ensino de $1^{\circ}$ e $2^{\circ}$ graus e constará dos planos curriculares dos estabelecimentos de ensino.

$\S 2^{\circ}$ - À preparação para o trabalho, no ensino de $2^{\circ}$ grau, poderá ensejar habilitação profissional, a critério do estabelecimento de ensino. (BRASIL, 1982).

Aqui começa uma distinção entre preparação para o trabalho, mais geral, e profissionalização, mais específica, diferença que acabará vingando na nova LDB 9394/96.

\title{
A LDB 9394/96
}

\author{
A tramitação da leI
}


A Lei de Diretrizes e Bases da Educação Nacional n. 9394 foi sancionada pelo governo Fernando Henrique Cardoso em 20 de dezembro de 1996 (BRASIL, 1996). Entretanto, diferentemente da LDB que veio a substituir a 5692/71, teve um processo lento e tumultuado de tramitação no Congresso Nacional, tendo sido aprovada 8 anos depois da primeira versão apresentada na Câmara dos Deputados. Foi a primeira lei educacional do país que teve sua origem no Poder Legislativo, fruto de um processo democrático, ainda que no final, como veremos, tenha vingado a proposta do Poder Executivo.

Não pretendo fazer um relato detalhado da tramitação dessa lei no Congresso até porque foge ao escopo desta pesquisa. Demerval Saviani já fez isso com muita profundidade no livro $A$ nova lei da educação, publicado um ano depois da aprovação da nova LDB. A $9^{a}$ edição desse livro (SAVIANI, 2004) foi a referência principal em que me baseei para reconstituir os aspectos principais da trajetória da LDB 9394 no Congresso Nacional, desde sua primeira versão até a aprovação final. Com isso pretendo evidenciar as disputas ideológicas e os conflitos de interesses entre progressistas e conservadores, especialmente entre os defensores da escola pública e os representantes das escolas privadas, que cresceram significativamente desde a aprovação da 5692/71. Diferentemente da época da 4024/61, quando esse enfrentamento também aflorou, no contexto da 9394/96 não era mais a Igreja Católica a principal representante dos interesses da iniciativa privada. Naquele momento já havia vários empresários bem sucedidos atuando no "negócio" da Educação e com interesses a defender no Congresso Nacional e no âmbito do Ministério da Educação (MEC). Claro que no início tinha outra conotação, mas não 
deixa de ser premonitório que o $\mathrm{MEC}^{42}$ tenha nascido com o nome de Ministério dos Negócios da Educação e Saúde Pública.

A origem mais remota da nova LDB pode ser buscada imediatamente após a promulgação da Constituição, em 5 de outubro de 1988. A nova lei maior coroava o processo de abertura política iniciado em 1985, com a eleição, pelo Colégio Eleitoral, de Tancredo de Almeida Neves, do Partido do Movimento Democrático Brasileiro (PMDB), herdeiro do MDB, em disputa com Paulo Maluf, do Partido Democrático Social (PDS), herdeiro da ARENA. Tancredo foi o primeiro presidente civil desde João Goulart, entretanto, como sabemos, veio a falecer e não ocupou o cargo. Em seu lugar, assumiu o então vice-presidente José Sarney de Araújo Costa, dissidente do PDS e recém filiado ao PMDB.

Portanto, a nova LDB começou a ser gestada sob um regime democrático, embora ainda incipiente. O primeiro projeto de lei foi apresentado na Câmara, em dezembro de 1988, pelo deputado mineiro Octávio Elísio, do Partido da Social Democracia Brasileira $(\mathrm{PSDB})^{43}$, com base no texto Contribuição à elaboração da nova LDB: um início de conversa, publicado por Demerval Saviani na Revista da ANDE n. 13. Essa proposta foi debatida na $V$ Conferência Brasileira de Educação, realizada em Brasília, em agosto de 1988, cujo tema principal foi exatamente "A Lei de Diretrizes e Bases da Educação Nacional” (SAVIANI, 2004).

Em março de 1989 o deputado cearense Ubiratan Aguiar (PMDB), então presidente da Comissão de Educação da Câmara, criou um Grupo de Trabalho da

42 No primeiro Governo Getúlio Vargas foi criado o Ministério da Educação e Saúde Pública por meio do Decreto n. 19402 de 14 de novembro de 1930: “Art. $1^{\circ}$ Fica criada uma Secretaria de Estado com a denominação de Ministério dos Negócios da Educação e Saúde Pública”. Somente no segundo Governo Vargas por meio do Decreto n. 1920 de 25 de julho de 1953 mudou-se o nome para Ministério da Educação e Cultura que deu origem à sigla MEC: “Art. $1^{\circ}$ É criado o Ministério da Saúde, ao qual ficarão afetos os problemas atinentes à saúde humana. [...] Art. $2^{\circ} \mathrm{O}$ Ministério da Educação e Saúde passa a denominar-se 'Ministério da Educação e Cultura'." Em 1985, no governo Sarney, o MEC foi desdobrado em dois ministérios. Por meio do Decreto 91144 de 15 de março de 1985 foi criado o Ministério da Cultura (MinC)

“Art. $1^{\circ}$ Fica criado na Organização do Poder Executivo Federal, por desdobramento do Ministério da Educação e Cultura, o Ministério da Cultura [...]. Art. 19. Passa a denominar-se 'Ministério da Educação' o atual Ministério da Educação e Cultura." Apesar de perder o "C" da "Cultura" até hoje o Ministério da Educação é chamado de MEC.

43 O PSDB foi fundado em 1988 por dissidentes do PMDB, como Fernando Henrique Cardoso, Mário Covas e Franco Montoro. Esteve no poder coligado com o PFL durante o Governo Fernando Henrique (1995-2002). Com a posse de Lula (PT) em 2003, foi para a oposição. (PSDB. História. Disponível em: $<w w w 2 . p s d b . o r g . b r / h i s t o r i a . a s p>$. Acesso em: 17 out. 2008). 
LDB que tinha como coordenador o deputado paulista Florestan Fernandes (PT) ${ }^{44} \mathrm{e}$ como relator o deputado baiano Jorge Hage (PSDB).

Como relator, coube a Jorge Hage analisar o projeto original de Octávio Elísio e as centenas de emendas dos parlamentares. Considerou também um grande número de sugestões de diversos setores da sociedade brasileira, ouviu dezenas de entidades e promoveu seminários com especialistas para discutir os pontos polêmicos do substitutivo que elaborava. $\mathrm{Na}$ avaliação de Saviani (2004, p. $57)$ :

O Deputado Jorge Hage, na condição de relator, demonstrou competência, tenacidade, capacidade de trabalho, habilidade de negociação e foi incansável no empenho em ouvir democraticamente todos os que, a seu juízo, pudessem de alguma forma contribuir para o equacionamento da matéria em pauta, tendo percorrido o país a convite ou por sua própria iniciativa para participar de eventos dos mais diferentes tipos em que expunha o andamento do projeto e acolhia as mais diversas sugestões.

Depois de intensas negociações e votações, em junho de 1990, a terceira versão do substitutivo elaborado por Jorge Hage foi aprovada na Comissão de Educação da Câmara, naquele momento presidida pelo deputado Carlos Sant'Anna ${ }^{45}$ (PMDB-BA), transformando-se no substitutivo da Comissão. Em seguida foi à apreciação da Comissão de Finanças, presidida por Sandra Cavalcanti, deputada conservadora do Partido da Frente Liberal (PFL) ${ }^{46}$ do Rio de Janeiro.

O Substitutivo corria o risco de ser arquivado caso não fosse aprovado até o final daquela legislatura. Entretanto, depois de superar as orquestrações dos deputados conservadores, no "apagar da luzes" daquele mandato, em dezembro de 1990, o substitutivo foi aprovado pela Comissão de Finanças. Agora o Substitutivo Jorge Hage, como ficou mais conhecido, precisaria passar pelo teste mais difícil: a

44 O PT foi fundado por meio de um Manifesto aprovado por 1200 pessoas reunidas no Colégio Sion (São Paulo) em 10 de feveiro de 1980. Entre seus fundadores estavam sindicalistas, como Luiz Inácio Lula da Silva e Olívio Dutra, e intelectuais, como Sérgio Buarque de Holanda e Mário Pedrosa. Nasceu em reação ao regime militar e esteve na oposição até a posse de Lula em $1^{\circ}$ de janeiro de 2003. (PT. Navegue no tempo. Disponível em: <www.pt.org.br/pt25anos>. Acesso em: 17 out. 2008).

45 Carlos Corrêa de Menezes Sant'Anna foi o último Ministro da Educação do Governo José Sarney, tendo permanecido no cargo entre 16/01/1989 e 14/03/1990. (MEC. Disponível em: <http://portal.mec.gov.br>. Acesso em: 12 ago. 2008).

46 O PFL foi fundado em 1985, após a eleição indireta de Tancredo Neves (PMDB), por dissidentes do PDS descontentes com a indicação de Paulo Maluf como candidato a presidente por esse partido. Deu apoio ao Governo Sarney (PMDB). No Governo do presidente Fernando Henrique (PSDB) indicou o vice, Marco Maciel, um dos fundadores do partido. Com a posse de Lula (PT) em 2003, foi para a oposição. Em 2007 mudou o nome para Democratas. (Democratas. História. <www.democratas.org.br/2144>. Acesso em: 17 out. 2008). 
apreciação do plenário da Câmara. Mas isso só iria acontecer na próxima legislatura, iniciada em 1991.

Esse processo de negociações no Congresso caracteriza o que Florestan Fernandes chamou na época de "conciliação aberta" (PINO, 2007; SAVIANI, 2004), o que evidentemente só poderia ocorrer sob um regime democrático no qual o Congresso funciona livremente. Trata-se de um fato novo, de uma nova realidade na História educacional e política do país, um grande avanço em comparação aos contextos anteriores, especialmente ao da 5692/71.

No caso do ensino médio, com a proposta de uma educação politécnica, como consta do artigo 53 do Substitutivo Jorge Hage, buscou-se a superação da histórica dicotomia entre a formação geral, propedêutica, e a formação específica, técnico-profissionalizante:

Assegurada aos alunos a integralidade da educação básica, que associa à educação mais geral, nesta etapa, as bases de uma educação tecnológica e politécnica, conforme disposto no artigo 51, o ensino médio poderá, mediante ampliação da sua duração e carga horária global, incluir objetivos adicionais de educação profissional. (SAVIANI, 2004, p. 89, anexo II).

O artigo 51, ao qual faz referência o texto acima, enuncia em seu caput que o ensino médio passa a ser considerado etapa final da educação básica. Entre os quatro incisos que definem os objetivos específicos, o IV abre caminho para uma educação politécnica ao propor "a compreensão dos fundamentos científicotecnológicos dos processos produtivos, relacionando a teoria com a prática, no ensino de cada disciplina científica". (SAVIANI, 2004, p. 89, anexo II).

Saviani (2004, p. 60), depois de fazer uma análise detalhada do Substitutivo Jorge Hage, considera que houve algum avanço:

O ensino médio constitui um verdadeiro nó na organização da educação escolar. Há uma grande dificuldade de se definir o lugar e o papel desse grau no conjunto do sistema de ensino. Embora no texto do projeto ainda persista um certo grau de dualidade entre o ensino geral e profissionalizante, deve-se reconhecer que já houve algum progresso no sentido de se localizar o eixo desse grau escolar na educação politécnica ou tecnológica.

E qual é a diferença entre educação técnica e educação politécnica? 
Ainda segundo Saviani (2004, p. 40), a primeira concepção vigorou a partir da LDB 5692/71 na qual "a profissionalização é entendida como um adestramento em uma determinada habilidade sem 0 conhecimento dos fundamentos dessa habilidade e, menos ainda, da articulação dessa habilidade com o conjunto do processo produtivo". A educação técnica, portanto, como já vimos, dava respostas ao regime de acumulação fordista (HARVEY, 1993).

Educação politécnica, por sua vez, "significa, aqui, especialização como domínio dos fundamentos das diferentes técnicas utilizadas na produção moderna". (SAVIANI, 2004, p. 39). Há aqui uma pequena contradição: se a proposta da formação politécnica consiste no "domínio dos fundamentos das diferentes técnicas", então não se trata de especialização. No próprio texto de Saviani, quando ele explicita sua proposta para o ensino médio politécnico, isso fica claro:

O ensino médio envolverá, pois, o recurso às oficinas nas quais os alunos manipulam os processos práticos básicos da produção; mas não se trata de reproduzir na escola a especialização que ocorre no processo produtivo. O horizonte que deve nortear a organização do ensino médio é o de propiciar aos alunos o domínio dos fundamentos das técnicas diversificadas utilizadas na produção, e não o mero adestramento em técnicas produtivas. Não a formação de técnicos especializados, mas de politécnicos. (2004, p. 39).

A educação politécnica, portanto, estaria apta a dar respostas às necessidades do regime de acumulação flexível (HARVEY, 1993), mas sem desprezar a formação humana.

Entretanto, apesar do apoio que obteve no início, essa proposta acabou não sendo bem sucedida. Depois de uma longa e tumultuada travessia pelos meandros da Câmara dos Deputados, desde sua aprovação na Comissão de Educação em junho de 1990, o Substitutivo Jorge Hage acabaria "morrendo na praia", como diz o dito popular.

Fernando Collor de Mello foi eleito presidente da República ao vencer Luiz Inácio Lula da Silva no pleito de 1989. Em sua posse em março de 1990, Carlos Alberto Chiarelli assumiu como ministro da Educação e imediatamente tachou de "muito ideológico" o projeto de LDB em discussão (SAVIANI, 2004). Nas eleições legislativas de outubro de 1990, foi eleito um Congresso de perfil mais conservador. Deputados comprometidos com o Substitutivo Jorge Hage e que tiveram uma 
atuação decisiva durante sua tramitação e aprovação nas Comissões, como o próprio autor, agora filiado ao Partido Democrático Trabalhista (PDT-BA), Octávio Elísio (PSDB-MG), Carlos Sant'Anna (PMDB-BA) e Gumercindo Milhomen (PT-SP), não se reelegeram. Isso fez com que os partidos progressistas perdessem o protagonismo na condução do processo de negociações que vinha desde a legislatura anterior.

$\mathrm{Na}$ leitura de Saviani (2004, p. 152), cresceu o papel dos partidos conservadores, representantes dos interesses privatistas no Congresso:

As relatorias das comissões de Educação e de Constituição e Justiça foram entregues ao PDS, partido de perfil conservador e bastante sensível aos interesses privatistas do campo educacional. No primeiro caso assumiu a relatoria a deputada Ângela Amin (PDS-SC); no segundo, o deputado Edevaldo Alves da Silva (PDS-SP), dono de uma grande rede de escolas em São Paulo. Para a Comissão de Finanças foi indicado como relator Luís Carlos Hauly (PMDB-PR, depois PST-PR), integrante do Bloco Economia de Mercado.

Iniciada a nova legislatura, o Substitutivo Jorge Hage foi levado a apreciação no plenário da Câmara no final de maio de 1991, tendo recebido 1263 emendas. Esse número excessivo foi apenas pretexto para que fosse obrigado a retornar às Comissões Técnicas para que tais emendas fossem examinadas. Ou seja, uma forma regimental de boicote por parte dos deputados conservadores.

As negociações se arrastaram pelo ano de 1991 sem que os representantes da Comissão Suprapartidária chegassem a um acordo sobre as emendas. Com isso, ficou definido que em maio de 1992 fosse votada, na Comissão de Educação, o parecer da deputada Ângela Amin (PDS-SC) sobre as 1263 emendas. Nova obstrução, desta vez articulada pelo deputado Eraldo Tinoco ${ }^{47}$ (PFLBA), líder do governo Colllor na Câmara, responsável por 1287 dos 1622 destaques apresentados. Novo impasse e mais um precioso tempo perdido, já que o segundo semestre de 1992 foi consumido pela Comissão Parlamentar de Inquérito que investigava Paulo Cesar Farias, tesoureiro da campanha de Fernando Collor, e pelo

47 Eraldo Tinoco Melo seria o terceiro e último ministro da Educação do Governo Fernando Collor. Substituiu José Goldemberg, porém ficou apenas dois meses à frente do cargo - entre 04/08/1992 e 01/10/1992 devido ao impeachment de Collor. (MEC. Disponível em: <http://portal.mec.gov.br>. Acesso em: 12 ago. 2008). 
movimento pró-impeachment do presidente. Com isso, a Comissão não conseguiu votar a matéria.

A posse de Itamar Franco e a indicação do professor Murílio de Avellar Hingel para o Ministério da Educação abriu uma nova perspectiva para a aprovação do Substitutivo Jorge Hage. Trabalhando desde novembro de 1992, finalmente em maio de 1993 a Câmara dos Deputados aprovou o projeto-substitutivo da Lei de Diretrizes e Bases da Educação Nacional que se transformou no Projeto de Lei 1158-B. Não era exatamente o texto elaborado inicialmente por Jorge Hage; para a aprovação da LDB foi necessário fazer concessões ao grupo privatista. Segundo Saviani (2004, p. 154):

O texto aprovado resultou bastante próximo da versão decorrente do Relatório de Ângela Amin, apesar de algumas modificações. A mudança mais visível ocorreu no Título V que deixou de ser "Do Sistema Nacional de Educação", passando para "Da Organização da Educação Nacional". Venceram, pelo menos nominalmente, já que se procurou preservar o conteúdo da denominação anterior, os deputados Eraldo Tinoco (PFL-BA) e Sandra Cavalcanti (PFL-RJ), secundados por Eurides Brito (PTR-DF), que opuseram tenaz resistência à manutenção do conceito de "sistema nacional de educação" no texto da LDB.

Num sistema bicameral como o brasileiro, o projeto de lei aprovado na Câmara dos Deputados tinha de ir a apreciação do Senado Federal. Ao entrar no Senado, o Projeto de Lei (PL) n. 1158-B foi identificado como Projeto de Lei da Câmara (PLC) n. 101, de 1993, tendo sido designado como relator da Comissão de Educação o senador Cid Sabóia (PMDB-CE).

Sabóia conduziu seus trabalhos de forma democrática, conforme atesta Saviani (2004, p. 155):

O relator adotou um procedimento semelhante àquele da fase de construção do substitutivo Jorge Hage, promovendo audiências públicas, consultando os que tinham contribuições a dar e ouvindo os representantes do governo, dos partidos e das entidades educacionais, além da interlocução com o Fórum Nacional em Defesa da Escola Pública.

O parecer do relator Cid Sabóia e o substitutivo ao PLC 101/93 foram aprovados na Comissão de Educação do Senado e alguns dias depois encaminhado para votação no plenário, onde deu entrada em novembro de 1994. Tudo parecia indicar que quase sete anos depois do início da tramitação, a LDB seria finalmente 
aprovada, mas sua apreciação ficou para a nova legislatura que se iniciaria no ano seguinte.

Houve uma mudança no cenário político com a eleição de um novo presidente - Fernando Henrique Cardoso (PSDB), sustentado por uma aliança de centro direita, a coligação PSDB-PFL, assumiu em $1^{\circ}$ de janeiro de 1995 - e um novo parlamento. O novo cenário era favorável ao avanço dos setores conservadores e a materialização de suas teses na LDB. O novo governo se mostrou contrário ao PLC 101/93 e ao Substitutivo Cid Sabóia. Para Saviani (2004, p. 159):

Tal posição se manifesta quando, apenas iniciada a nova Legislatura, o senador Beni Veras (PSDB-CE) apresenta requerimento solicitando o retorno do projeto de LDB à Comissão de Constituição, Justiça e Cidadania. A trajetória do projeto já estava entrando em área de turbulência.

E quem ficou responsável pela relatoria do projeto da LDB na Comissão de Constituição, Justiça e Cidadania do Senado? Ninguém menos que o onipresente Darcy Ribeiro ${ }^{48}$. O então senador pelo PDT-RJ já havia tentado uma manobra para atropelar o projeto da LDB. Durante o governo Collor, enquanto o Substitutivo Jorge Hage tramitava na Câmara, Ribeiro elaborou um projeto de LDB que foi apresentado ao Senado. Contou para isso com a assessoria de técnicos do MEC, naquele momento sob o comando de José Goldemberg, contrário ao teor do Substitutivo Jorge Hage. O relator daquele projeto era o então senador Fernando Henrique Cardoso (PSDB-SP). Com a renúncia de Fernando Collor e a chegada de Itamar Franco à presidência houve uma mudança na correlação de forças, que se tornou desfavorável ao projeto Darcy Ribeiro. O ministro da Educação de Itamar Franco, Murílio Hingel, era favorável ao projeto da Câmara e conseguiu articular com senadores aliados o arquivamento do projeto do senador carioca. No fim, como disse Saviani (2004), aquela tentativa de "roubar a cena" do protagonismo da Câmara na elaboração da nova LBD, mostrou-se frustrada. Entretanto, sob a presidência de Fernando Henrique Cardoso, as concepções de Educação e

\footnotetext{
48 Darcy Ribeiro foi ministro da Educação do Governo João Goulart entre 18/09/1962 e 23/01/1963. (MEC.
} Disponível em: <http://portal.mec.gov.br>. Acesso em: 12 ago. 2008). 
democracia de Darcy Ribeiro e do novo governo se convergem e desta vez ele seria bem sucedido.

Em maio de 1995, o senador Darcy Ribeiro apresenta seu parecer. Nele indicava diversas inconstitucionalidades para inviabilizar tanto o PLC 101/93 quanto - Substitutivo do senador Cid Sabóia. Depois de considerá-los inadequados ${ }^{49}$, elabora um substitutivo próprio que foi aprovado na Comissão de Constituição, Justiça e Cidadania do Senado.

Sua atitude, como era de se esperar, provocou um profundo descontentamento entre os que defendiam o projeto de LDB democraticamente construído e consubstanciado no PLC $101 / 93$ e no Substitutivo Cid Sabóia. Na tentativa de minimizá-lo, o senador foi incorporando emendas ao seu projeto, a última versão, com 91 artigos, foi aprovada no plenário do Senado em fevereiro de 1996. Apesar de aproveitar alguns aspectos da proposta da Câmara, como indica Demerval Saviani, há uma clara convergência de pontos de vista e de interesses entre o senador Darcy Ribeiro, o governo Fernando Henrique (o MEC agora estava sob o comando do ministro Paulo Renato Souza) e os empresários do setor educacional. Saíram perdendo a escola pública e a democracia:

Vê-se que essa estrutura se baseia fortemente naquela do primeiro projeto de $\mathrm{D}$. Ribeiro com leves alterações baseadas no projeto aprovado na Câmara. Quanto ao conteúdo, se distancia bastante do primeiro projeto, aproximando-se da proposta da Câmara sob o aspecto da organização das bases, isto é, dos níveis e modalidades de ensino. Já no que diz respeito ao controle político e à administração do sistema educacional, retoma a orientação do primeiro projeto aperfeiçoando-a e sintonizando-a com as linhas da política educacional do governo de Fernando Henrique Cardoso.

A se depreender da manifestação de João Carlos Di Gênio, proprietário da Rede de Cursos e Colégios "Objetivo" e da "Universidade Paulista" (UNIP), o texto aprovado no Senado correspondeu inteiramente às expectativas dos empresários do ensino. (SAVIANI, 2004, p. 161).

Como o projeto nasceu no Senado, agora teria de ser enviado a apreciação da Câmara dos Deputados. Ali chegando o Substitutivo Darcy Ribeiro teve como relator o deputado José Jorge (PFL-PE). Como o governo Fernando Henrique Cardoso tinha maioria na Câmara, o relatório de José Jorge com o texto final da LDB foi aprovado em dezembro de 1996. Manteve praticamente a mesma

$49 \quad$ Vale relembrar que o substitutivo Cid Sabóia manteve basicamente a mesma estrutura do Substitutivo Jorge Hage do qual se originou o PLC 101/93 (SAVIANI, 2004). 
estrutura do Substitutivo Darcy Ribeiro e sobretudo o espírito geral do projeto. Em seguida foi à sanção presidencial e Fernando Henrique Cardoso aprovou-o sem vetos.

Saviani (2004) nos lembra que a ausência de vetos é um fato raro na política educacional brasileira e que a 5692/71 também tinha sido aprovada assim. Mas naquela época o país vivia em plena ditadura militar-civil. No caso da 9394/96, o Poder Executivo, por meio do Ministério da Educação, foi co-autor da lei e se empenhou diretamente na sua aprovação:

Com isso, o projeto não precisou voltar à Câmara e foi promulgado em 20 de dezembro de 1996, dando origem à Lei n. 9394, que estabelece as Diretrizes e Bases da Educação Nacional. Essa lei ficou mais conhecida como LDB 9394/96.

\section{UMA LEI MINIMALISTA}

A LDB 9394/96 acabou se configurando como uma lei minimalista, genérica (PINO, 2007; RAMOS, 2005; SAVIANI, 2004), diria mesmo, negligente: copiou praticamente todos os artigos 205 a 208 da Constituição de 1988. Com isso, renunciou a seu papel de lei que efetivamente define as Diretrizes e as Bases da Educação Nacional, deixando grande parte dessa prerrogativa para leis complementares: decretos, resoluções etc. Esse é o ponto de vista de Pino (2007, p. 32), que acredita que a LDB tem sobretudo um papel legitimador das reformas que estão sendo feitas na educação brasileira, tanto pelo MEC como por alguns Estados e Municípios:

O nível de generalização da LDB é de tal envergadura que a torna menos importante como lei maior da educação nacional, isto é, as diretrizes e bases da educação nacional que reordenam de fato a educação caminham por fora da LDB: nas medidas provisórias, emendas constitucionais, projetos de lei encaminhados pontualmente ao Congresso pelo Executivo e nas resoluções e portarias do MEC.

Ramos (2005, p. 237) argumenta que pelo fato de ser uma lei minimalista, a LDB 9394/96 "permitiu uma onda de reformas na educação brasileira". Mais do que permitiu, exigiu, já que foi uma lei negligente. Severino (2007, p. 64) demonstra 
seu estranhamento com relação à retomada muitas vezes ipsis litteris do texto constitucional: "Estranhamente, o legislador não se preocupou em ampliar as conceituações feitas, especificando melhor a significação desses princípios, concretizando-os mediante uma delimitação de seu alcance.". Em seguida questiona: "Não é esse o papel do legislador ao elaborar as leis complementares?" O problema é que quando se fala em "legislador", no $\operatorname{singular}^{50}$, corre-se o risco de obscurecer que são os "legisladores", no plural, que elaboram as leis. Assim, a LDB como qualquer outra lei é fruto dos enfrentamentos, das contradições e dos conflitos de interesses dos partidos políticos e dos partidos ideológicos que esses legisladores - deputados e senadores - representam. Na elaboração da nova LDB, como vimos, o conflito principal se deu entre, de um lado, os defensores da educação pública, universal, obrigatória e gratuita, e, de outro, os defensores da educação privada, necessariamente elitista, especialmente no Brasil, onde a distribuição de renda é muito desigual.

Saviani (2004) não vê nenhum estranhamento no minimalismo da lei. Também não vejo. Para ele uma "LDB minimalista" era compatível com o "Estado mínimo" perseguido pela política neoliberal ${ }^{51}$ dominante na época. Se bem que como nos alerta Frigotto (2003, p. 163): "Estado mínimo significa o Estado máximo a serviço dos interesses do capital.". Demerval Saviani foi um dos pesquisadores que melhor deu conta de explicar o porquê dessa concepção minimalista da lei. Sim, porque não foi por acaso, trata-se de uma clara opção do MEC encampada pelo Substitutivo elaborado pelo senador Darcy Ribeiro:

Certamente essa via foi escolhida para afastar as pressões das forças organizadas que atuavam junto ou sobre o Parlamento de modo a deixar o caminho livre para a apresentação e aprovação de reformas pontuais, tópicas, localizadas, traduzidas em medidas como o denominado 'Fundo de Valorização do Magistério', os 'Parâmetros

50 Outros autores, como Pinto (2007), também usam “legislador", no singular, para se referir aos sujeitos que elaboraram a LDB.

51 Doutrina político-econômica que retoma os princípios básicos do liberalismo clássico, buscando adaptá-los ao capitalismo do período atual. Como os clássicos, seus defensores acreditam na livre iniciativa individual, na livre concorrência entre as empresas e no mercado como organizador das relações econômicas. Entretanto, diferentemente daqueles, não crêem na autodisciplina espontânea do sistema, por isso, defendem que o Estado deve intervir minimamente na economia para garantir a estabilidade financeira e monetária (SANDRONI, 2001). Políticas econômicas neoliberais estiveram muito em voga na década de 1980, inicialmente no Reino Unido, sob o governo Margareth Thatcher, e nos Estados Unidos, sob o governo Ronald Reagan, e especialmente na década de 1990, quando se espalharam para vários países. Entretanto, nos anos 2000, essa doutrina vem sendo crescentemente contestada. 
Curriculares Nacionais', a lei de reforma do ensino profissional e técnico [...] (SAVIANI, 2004, p. 200).

Isso explica a estratégia do MEC de malograr, sob a mediação do senador Darcy Ribeiro, o projeto de LDB originário do Substitutivo Jorge Hage aprovado na Câmara dos Deputados e depois, no Senado, transformado no Substitutivo Cid Sabóia. Caso aquele projeto, que era muito mais detalhado, fosse aprovado, o MEC não teria muita margem de manobra para implementar as reformas pontuais da maneira que mais lhe conviesse.

Severino (2007, p. 64), após o estranhamento, também apresenta uma explicação plausível para o minimalismo da LDB, que para ele não inova muito, apenas retoma com pequenos retoques os princípios do liberalismo, agora lustrados com verniz neoliberal:

O processo de enxugamento sofrido pelo texto originário da Câmara, na verdade, correspondeu ao expurgo de algumas definições mais avançadas em termos ideológicos, no sentido de que, produzidas por um trabalho mais participativo, expressavam conquistas mais universais. A incorporação de fragmentos do texto originário com essa conotação não parece garantir sua implementação, uma vez que não conseguem reverter as tendências consolidadas da orientação neoliberal, que domina não só o texto e o espírito da lei, mas todo o contexto da história sociopolítica brasileira do momento.

Diversos autores afirmam que a LDB 9394/96 é uma lei de concepção neoliberal (FRIGOTTO, 2003; RAMOS, 2005; SAVIANI, 2004; SEVERINO, 2007). Saviani (2004, p. 200), ao questionar se é correta essa avaliação, assim responde:

Levando-se em conta o significado correntemente atribuído ao conceito de neoliberal, a saber: valorização dos mecanismos de mercado, apelo à iniciativa privada e às organizações não-governamentais em detrimento do lugar e do papel do Estado e das iniciativas do setor público, com a conseqüente redução das ações e dos investimentos públicos, a resposta será positiva.

Quanto à vitória dos interesses do mercado e da iniciativa privada, pelo que vimos no processo de tramitação da LDB 9394/96 e em seu texto final, parece não restar dúvidas. Entretanto, desde a promulgação dessa lei não houve propriamente uma redução dos investimentos públicos em Educação, especialmente no nível básico (tabelas 2, 3 e 4). Na realidade, houve um crescimento, tanto em termos absolutos (em bilhões de reais) quanto relativos (em \% do PIB), embora 
pequeno, insuficiente diante das enormes carências do sistema educativo, das necessidades de formação de mão-de-obra para o país e especialmente incompatível com o discurso oficial de prioridade à área educacional.

\begin{tabular}{|l|c|c|}
\hline \multicolumn{3}{|c|}{$\begin{array}{c}\text { Tabela 2. Brasil: investimento público em } \\
\text { educação básica (em bilhões de reais) }\end{array}$} \\
\hline Ensino & $\mathbf{1 9 9 6}^{\boldsymbol{*}}$ & $\mathbf{2 0 0 6}^{\star *}$ \\
\hline \hline Infantil & 6,1 & 5,3 \\
\hline Fundamental & 35,0 & 48,6 \\
\hline Médio & 6,2 & 6,5 \\
\hline Total & 47,2 & 60,3 \\
\hline
\end{tabular}

Fonte: *IPEA/DISOC; IBGE; SIAFI/STN. In: Castro (2007, p. 862); **MF/Tesouro Nacional. Série histórica de receitas e despesas. In: DIEESE (2007. p. 97).

\begin{tabular}{|l|c|c|}
\hline \multicolumn{3}{|c|}{$\begin{array}{c}\text { Tabela 3. Brasil: investimento público em } \\
\text { educação (em \% do PIB) }\end{array}$} \\
\hline Educação & $\mathbf{1 9 9 6}^{\star}$ & $\mathbf{2 0 0 4}^{\star *}$ \\
\hline Básica & 3,0 & 3,3 \\
\hline Superior & 0,9 & 0,8 \\
\hline Total & 3,9 & 4,1 \\
\hline
\end{tabular}

Fonte: *IPEA/DISOC; IBGE/MP; INEP/MEC e Almeida (2001). In: Castro (2007, p. 867);

${ }^{* \star M E C / I n e p . ~ G a s t o s ~ p u ́ b l i c o s ~ e m ~ e d u c a c ̧ a ̃ o . ~ I n: ~ D I E E S E ~(2007 . ~ p . ~ 98) . ~}$

\begin{tabular}{l}
\hline Tabela 4. Brasil: investimento em educação básica por esfera de \\
governo \\
\hline \multirow{2}{*}{ Ano } \\
\cline { 2 - 9 }
\end{tabular}

Fonte: IPEA/DISOC; IBGE/MP; INEP/MEC e Almeida (2001). In: Castro (2007, p. 865).

De fato, a realidade mostrada pelos números das tabelas acima pode ser atribuída a políticas macroeconômicas de cunho neoliberal. Após analisar os gastos públicos ${ }^{52}$ em Educação no Brasil, Castro (2007, p. 869-870) afirma:

52 Castro (2007) fala o tempo todo em “gasto público". Mesmo sabendo que do ponto de vista da contabilidade governamental de fato se trata de "despesa", de "gasto", com relação à Educação prefiro o termo “investimento público”. Não é apenas um preciosismo semântico, mas uma importante questão simbólica. Como disse o presidente Lula em discurso: "tomamos uma decisão no governo, já em 2004, de que era 
Pode-se concluir, após examinar esses dados, que a não ampliação da importância dos gastos em educação demonstra, claramente, o sentido do ajuste macroeconômico imposto à sociedade brasileira, sobretudo no período de crise da política de estabilização monetária. Por isso, em todo o período, a prioridade macroeconômica da área de educação pouco se alterou, apesar do discurso em prol da educação.

Os dados das tabelas permitem concluir que o "neoliberalismo", ou seja, a redução de investimentos na Educação, é mais evidente para os governos estadual e principalmente federal. O que se observa desde a LDB 9394/96 é um crescente processo de descentralização dos dispêndios com Educação. Entretanto, ao mesmo tempo houve maior centralização das decisões nas mãos do MEC, o que de qualquer modo está de acordo com a LDB, artigo 8, parágrafo 10: "Caberá à União a coordenação da política nacional de Educação, articulando os diferentes níveis e sistemas e exercendo função normativa, redistributiva e supletiva em relação às demais instâncias educacionais." (BRASIL, 1996). Como mostra a tabela 4, a participação dos Municípios nos investimentos em Educação pública aumentou significativamente, ao mesmo tempo em que reduziu a participação dos Estados e especialmente do governo federal.

Deve ser lembrado que esse cenário está de acordo com 0 inciso $V$ do artigo 11 da LDB no qual se enuncia que cabe aos municípios "oferecer a educação infantil em creches e pré-escolas, e, com prioridade, o ensino fundamental." (BRASIL, 1996). O qual apenas regulamenta o parágrafo $2^{\circ}$ do artigo 211 da Constituição (BRASIL, 1988): "Os Municípios atuarão prioritariamente no ensino fundamental e na educação infantil.". Ao se observar os números da tabela 2 percebe-se que o nível de ensino no qual o investimento público mais cresceu foi exatamente o fundamental.

Esse aumento de recursos concentrado no ensino fundamental em detrimento do infantil e do médio deve-se à aprovação da Lei 9424 de 24 de dezembro de 1996, que regulamentou o Fundo de Manutenção e Desenvolvimento

proibida a palavra 'gasto' em educação. [...] Em outras coisas a gente pode até dizer isso, mas em educação e em saúde não podemos dizer que é gasto. É um processo de educação que parece insignificante, mas não é. É muito forte não utilizar a palavra gasto para coisas que são investimento." (BRASIL, 2008). Seguindo essa orientação presidencial, no portal do Instituto Nacional de Estudos e Pesquisas Educacionais Anísio Teixeira, o título da seção onde há informações sobre a aplicação de recursos na Educação é: "Investimentos Públicos em Educação" (INEP, 2008). 
do Ensino Fundamental e de Valorização do Magistério (FUNDEF). A Emenda Constitucional n. 14 de 1996 que criou o FUNDEF estabeleceu um prazo de 10 anos para sua vigência, o que se encerrou em 2006. Porém, a implantação desse fundo, ou seja, a distribuição de seus recursos para a educação fundamental só começou efetivamente em 1998. Isso explica a situação de penúria do ensino médio. Pior ainda é a situação do ensino infantil que teve queda de investimentos ao invés de aumento, entretanto, não discutirei esse nível de ensino porque foge ao escopo desta pesquisa.

Em 2006, ano em que o FUNDEF foi extinto, os investimentos em educação fundamental representaram um aumento de 38,9\% em comparação com os valores despendidos em 1996, ano em que foi criado. No ensino médio, que não foi contemplado pelo fundo, os investimentos de 2006 representaram um aumento de apenas 4,8\% em comparação com 1996. E isso num período em que houve um enorme crescimento das matrículas nesse nível de ensino (isso será tratado mais à frente, ver tabela 5). É inviável incorporar milhares de novos alunos ao sistema, garantindo-Ihes ensino de qualidade sem o correspondente aumento de recursos. 0 Fundo de Desenvolvimento e Manutenção da Educação Básica e Valorização dos Profissionais da Educação (FUNDEB) foi criado por meio da Lei 11494 de 20 de junho de 2007 com a intenção de ampliar os recursos para os níveis que não eram contemplados pelo FUNDEF, o que inclui o ensino médio.

Para que essa lei fosse criada, antes foi necessária mais uma modificação no texto da Constituição. A Emenda Constitucional n. 53 de 2006 introduziu as mudanças para viabilizar o FUNDEB. Com isso, o parágrafo $5^{\circ}$ do artigo 212 passou a ter a seguinte redação: "A educação básica pública terá como fonte adicional de financiamento a contribuição social do salário-educação, recolhida pelas empresas na forma da lei." (BRASIL, 1988). A única mudança em relação à Emenda anterior, a de n. 14 de 1996, que viabilizou o FUNDEF, é que "educação básica" entrou no lugar de "ensino fundamental". A educação básica é composta pelo ensino fundamental, mas também pelo infantil e médio. Com isso o FUNDEB passa a financiar esses dois níveis de ensino, além de contemplar também creche, educação especial e educação de jovens e adultos (EJA). O FUNDEB passou a 
vigorar a partir de $1^{\circ}$ de janeiro de 2007 e seu prazo de vigência é até 2020 . De acordo com o artigo $3^{\circ}$ da lei 11494 , esse fundo é composto, no âmbito de cada Estado e do Distrito Federal, por $20 \%$ das receitas de diversos tributos como o imposto sobre transmissão causa mortis e doação de quaisquer bens ou direitos, imposto sobre circulação de mercadorias e serviços, imposto sobre propriedade de veículos automotores etc. Complementando essas receitas o governo federal comprometeu-se a fazer aportes de 2 bilhões de reais em 2007, 3 bilhões em 2008, 4,5 bilhões em 2009 e 10\% do montante resultante da contribuição dos Estados e Municípios a partir de 2010. Com isso se espera que o ensino médio tenha uma fonte permanente para financiar a sua expansão e sobretudo a melhoria da qualidade da Educação oferecida.

A seguir serão analisados os documentos que vêm orientando a reforma do ensino médio do ponto de vista curricular, que são desdobramentos da LDB 9394/96 e legitimados por ela: as Diretrizes Curriculares Nacionais para o Ensino Médio (DCNEM), os Parâmetros Curriculares Nacionais do Ensino Médio (PCNEM) e as Orientações Curriculares para o Ensino Médio (OCEM).

\section{A reforma do ensino médio: DCNEM, PCNEM...}

\section{Adaptação à sociedade do CONHeCimento}

$\mathrm{Na}$ introdução da parte I dos Parâmetros Curriculares Nacionais do Ensino Médio (PCNEM), dedicada às Bases Legais, já fica evidente que o processo de reforma curricular do ensino médio é uma exigência da revolução tecnológica e da crescente importância do papel do conhecimento nas relações sociais:

A denominada "revolução da informática" promoveu mudanças radicais no conhecimento, que passa a ocupar um lugar central nos processos de desenvolvimento, em geral. [...] 
As propostas de reforma curricular para o Ensino Médio se pautam nas constatações sobre as mudanças no conhecimento e seus desdobramentos, no que se refere à produção e às relações sociais de modo geral. (BRASIL, 2002a, p. 15).

Isso fica ainda mais evidente no trecho a seguir:

Pensar um novo currículo para o Ensino Médio coloca em destaque esses dois fatores: as mudanças estruturais que decorrem da chamada "revolução do conhecimento", alternando o modo de organização do trabalho e as relações sociais; e a expansão crescente da rede pública, que deverá atender a padrões de qualidade que se coadunem com as exigências desta sociedade. (BRASIL, 2002a, p. 16, grifo do autor).

O Parecer da Câmara de Educação Básica (CEB n. 15/98) que introduz as Diretrizes Curriculares Nacionais para o Ensino Médio (DCNEM), que, por sua vez, precedem os PCNEM, também não deixa a menor dúvida sobre o objetivo da reforma curricular:

Inicia-se, assim, em meados dos anos 80 e primeira metade dos 90 um processo, ainda em curso, de revisão das funções tradicionalmente duais da Educação Secundária, buscando um perfil de formação do aluno mais condizente com as características da produção pós-industrial. O esforço da reforma teve como forte motivação inicial as mudanças econômicas e tecnológicas." (BRASIL, 2002a, p. 71).

Os elaboradores dos PCNEM ora falam em "revolução da informática" ora em "revolução do conhecimento", quando não em "produção pós-industrial", como menciona as DCNEM. Como se vê, as justificativas dos documentos brasileiros para a reforma educacional são muito semelhantes às que constam na proposta espanhola, que, por sua vez, fala em adequação da escola à "nova sociedade do conhecimento", como veremos a seguir.

Mas, quais são as "mudanças estruturais", as "exigências" da chamada sociedade do conhecimento? O discurso da "comunidade epistêmica" (LOPES, 2006) encarregada pela elaboração dos documentos vai no sentido de promover mudanças efetivas para preparar melhor os alunos para a sociedade do conhecimento ou se trata apenas de prescrição ideológica de caráter lampedusiano?

Para fazer frente a essas mudanças o governo do presidente Fernando Henrique Cardoso (1995-2003) achou por bem criar referenciais curriculares em nível nacional com as DCNEM e os PCNEM. Mas, qual é o sentido do ensino médio? 


\section{Propedêutico, técnico ou preparação básica para o trabalho}

O ensino ministrado nas escolas brasileiras, de forma geral, ainda responde às demandas da segunda revolução industrial, da era fordista, de um mundo do passado. Nas escolas públicas, em sua maioria, isso ocorre como conseqüência dos conhecidos problemas que atrapalham uma melhor formação dos estudantes: insuficiente formação dos professores, carências socioeconômicas dos alunos, infraestrutura precária. Em muitas escolas privadas tem havido uma crescente disseminação dos chamados "sistemas de ensino", com suas apostilas e aulas numeradas, nos quais impera um "fordismo educacional", com o professor engessado e transformado em "operário na linha de transmissão de conhecimento". São poucas escolas públicas e mesmo privadas que formam alunos emancipados, realmente preparados para o mundo de hoje. Atualmente vivemos a terceira revolução industrial, a era pós-industrial (BELL, 2006) ou da produção flexível (HARVEY, 1993), portanto, está havendo uma mudança de regime de acumulação e grande parte das escolas públicas e privadas não está acompanhando. Na visão de Pontuschka (1999a, p. 112):

A escola da fábrica do século passado ainda está aí e não dá conta da formação desse jovem. Há que se pensar em um ensino que forme o aluno do ponto de vista reflexivo, flexível, crítico e criativo. Não é uma formação para o mercado de trabalho apenas, mas um jovem preparado para enfrentar as transformações cada vez mais céleres que certamente virão.

Conseqüentemente, são outras as demandas, não apenas para o trabalhador, mas também para o cidadão, ou seja, para a pessoa de forma integral, já que não se deve separar essas duas categorias sociais. Como vimos, a educação escolar não deve dar respostas apenas ao mercado de trabalho, mas não se pode desprezar essa dimensão da pessoa humana.

O PCNEM, em sua introdução, faz essas mesmas constatações quando, ao discorrer sobre as características do novo ensino médio, afirma: 
Nas décadas de 60 e 70, considerando o nível de desenvolvimento da industrialização na América Latina, a política educacional vigente priorizou, como finalidade para o Ensino Médio, a formação de especialistas capazes de dominar a utilização de maquinarias ou de dirigir processos de produção. Esta tendência levou o Brasil, na década de 70 , a propor a profissionalização compulsória, estratégia que também visava a diminuir a pressão da demanda sobre o Ensino Superior.

$\mathrm{Na}$ década de 90 , enfrentamos um desafio de outra ordem. O volume de informações, produzido em decorrência das novas tecnologias, é constantemente superado, colocando novos parâmetros para a formação dos cidadãos. Não se trata mais de acumular conhecimentos. (BRASIL, 2002a, p. 15).

Sobre a última frase do documento do PCNEM acima citado, vale lembrar que a idéia de acúmulo está mais associada a dados e a informações, não a conhecimentos. Pelo conteúdo da frase anterior, é o acúmulo de informações que se critica. De qualquer modo, o simples acúmulo de informações também não garante a passagem para o terceiro nível da pirâmide informacional (rever figura 1) mostrada por Machado (2000), não garante a produção de conhecimento, não assegura o compreender, ou seja, o apreender o novo com o já conhecido, como já disse Marina (1995).

Buscando dar respostas a essas novas demandas, ainda na introdução do PCNEM:

Propõe-se, no nível do Ensino Médio, a formação geral, em oposição à formação específica; o desenvolvimento das capacidades de pesquisar, buscar informações, analisá-las e selecioná-las; a capacidade de aprender, criar, formular, ao invés do simples exercício de memorização. (BRASIL, 2002a, p. 16).

No novo ensino médio, há uma ênfase na "formação geral". Percebe-se aqui uma significativa diferença em relação ao antigo segundo grau, herdeiro da LDB 5692/71.

Quando se fala em "desenvolvimento das capacidades de pesquisar, buscar informações, analisá-las e selecioná-las", está se falando em produção de conhecimentos a partir da busca de informações relevantes. Isso fica mais claro quando se propõe "a capacidade de aprender, criar, formular, ao invés [sic] do simples exercício de memorização". De fato, não se aprende, não se cria, não se formula, enfim, não se produz conhecimentos, apenas acumulando informações, que é característico do exercício de memorização, fórmula muito disseminada na prática pedagógica da escola que se quer superar. 
A "formação específica", que se supõe superada, era assegurada pela LDB 5692/71, que refletia a realidade da segunda revolução industrial, então em curso, e procurava dar respostas às suas necessidades, ou seja, ao regime de acumulação fordista, como definiu Harvey (1993). Dava ênfase, especialmente no antigo segundo grau, à habilitação técnica, com a profissionalização compulsória, como constatamos pela leitura dos parágrafos $1^{\circ}$ e $2^{\circ}$ do artigo $5^{053}$.

Reforçando o papel do antigo segundo grau como formador de mão-deobra para a indústria, o artigo 6을 pregava que a formação profissional poderia ser realizada em cooperação com as empresas. Como vimos, essa formação profissional, na prática, sob a perspectiva da indústria, era quase que só adestramento.

A LDB 9394/96, principal referência legal para as propostas de mudanças, reflete o mundo da terceira revolução industrial em andamento e procura dar conta das novas demandas em termos de competências ensejadas por ela, o que é típico do regime de acumulação flexível (HARVEY, 1993) e da sociedade do conhecimento (CASTELLS, 2000).

Os elaboradores dos PCNEM, quando discutem o papel da Educação na sociedade tecnológica, fazem-se esta pergunta: "De que competências se está falando?", à qual respondem:

Da capacidade de abstração, do desenvolvimento do pensamento sistêmico, ao contrário da compreensão parcial e fragmentada dos fenômenos, da criatividade, da curiosidade, da capacidade de pensar múltiplas alternativas para a solução de um problema, ou seja, do desenvolvimento do pensamento crítico, da capacidade de trabalhar em equipe, da disposição para o risco, do saber comunicar-se, da capacidade de buscar conhecimento. (BRASIL, 2002a, p. 24).

Percebe-se que o documento privilegia o saber-fazer, os saberes tácitos, a flexibilidade, enfim, a dimensão experimental da qualificação, que ganha importância com o advento da noção de competências.

Antes de fazerem a lista acima, parece-me que os elaboradores do documento foram exageradamente otimistas ao acreditarem que, como decorrência da revolução tecnológica, houve uma convergência em termos de competências

\footnotetext{
53 Ver os respectivos parágrafos na página 105.
} 
entre o que é necessário para a atividade produtiva e para o pleno desenvolvimento do ser humano.

A nova sociedade, decorrente da revolução tecnológica e seus desdobramentos na produção e na área da informação, apresenta características que possibilitam assegurar à educação uma autonomia ainda não alcançada. Isto ocorre na medida em que o desenvolvimento das competências cognitivas e culturais exigidas para o pleno desenvolvimento humano passa a coincidir com o que se espera na esfera da produção. (BRASIL, 2002a, p. 23).

Essa proposição não leva em consideração a racionalidade instrumental que perpassa toda a sociedade e, conseqüentemente, o currículo; não apenas o proposto nos documentos, mas também o real desenvolvido nas escolas. Perpassa também outras determinações do currículo real, como, por exemplo, os exames vestibulares, uma instância fortemente instrumentalizada da sociedade e com grande capacidade de influenciar o currículo realmente praticado nas escolas, especialmente naquelas voltadas para os estudantes de classe média.

Como já vimos, Ramos (2002a) faz uma crítica à noção de competência, associando-a à reforma curricular de cunho neoliberal que só reforçaria a competitividade e o individualismo. Argumenta que o conceito de competência é considerado mais adequado ao dinamismo típico da produção flexível e às novas demandas do capital, e por isso estaria substituindo o conceito de qualificação, associado à produção fordista, a uma visão estática do mundo do trabalho. Isso tem diversas implicações na concepção do currículo e na formação dos estudantes.

No âmbito da LDB 9394/96 foi superada a dicotomia antes existente no antigo segundo grau entre o caráter propedêutico e o técnico. De acordo com a atual lei, em seu artigo 35, o novo ensino médio é uma etapa final da educação básica e têm as seguintes finalidades:

I - a consolidação e o aprofundamento dos conhecimentos adquiridos no ensino fundamental, possibilitando o prosseguimento de estudos;

II - a preparação básica para o trabalho e a cidadania do educando, para continuar aprendendo, de modo a ser capaz de se adaptar com flexibilidade a novas condições de ocupação ou aperfeiçoamento posteriores;

III - o aprimoramento do educando como pessoa humana, incluindo a formação ética e o desenvolvimento da autonomia intelectual e do pensamento crítico; 
IV - a compreensão dos fundamentos científico-tecnológicos dos processos produtivos, relacionando a teoria com a prática, no ensino de cada disciplina. (BRASIL, 1996).

Os documentos da reforma brasileira, a começar pela LDB 9394/96, foram inspirados no Relatório para a UNESCO (DELORS, 2001), como fica evidente por este trecho da introdução da parte I do PCNEM:

É importante destacar, tendo em vista tais reflexões, as considerações oriundas da Comissão Internacional sobre Educação para o Século XXI, incorporadas nas determinações da Lei $n^{\circ}$ 9394/96:

a) a educação deve cumprir um triplo papel: econômico, científico e cultural;

b) a educação deve ser estruturada em quatro alicerces: aprender a conhecer, aprender a fazer, aprender a viver e aprender a ser. (BRASIL, 2002a, p. 27).

No item "l” do artigo 35 da LDB 9394/96 fica evidente a dimensão conceitual e o caráter propedêutico do novo ensino médio, que supostamente atenderia aqueles estudantes que estivessem interessados em continuar os estudos em nível superior.

No item "Il" do mesmo artigo aparece um dos pilares propostos pelo Relatório para a UNESCO, o "aprender a aprender", que remete a uma dimensão mais procedimental e que em tese proporcionaria uma formação mais adequada a um mundo em rápida transformação, especialmente no mercado de trabalho. Aqui, a "preparação básica para o trabalho" é diferente da "habilitação profissional" que vigorava sob a 5692/71. Trata-se de uma preparação genérica, em termos de competências demandadas pelo mundo do trabalho, sob a atual revolução tecnológica, e não de uma qualificação, uma profissionalização específica como existia antes. Como consta nas DCNEM:

A concepção da preparação para o trabalho, que fundamenta o Artigo 35, aponta para a superação da dualidade do Ensino Médio: essa preparação será básica, ou seja, aquela que deve ser base para a formação de todos e para todos os tipos de trabalho. Por ser básica, terá como referência as mudanças nas demandas do mercado de trabalho, daí a importância da capacidade de continuar aprendendo; não se destina apenas àqueles que já estão no mercado de trabalho ou que nele entrarão no curto prazo; nem será preparação para o exercício de profissões específicas ou para a ocupação de postos de trabalho determinados. (BRASIL, 2002a, p. 70, grifo do autor). 
Observe que o inciso II do artigo 35 da LDB 9394/96 fala em "preparação básica para o trabalho", entretanto, $\mathrm{O}$ artigo $2^{\circ}$ do mesmo documento fala em "qualificação para o trabalho":

Art. $2^{\circ}$. A educação, dever da família e do Estado, inspirada nos princípios de liberdade e nos ideais de solidariedade humana, tem por finalidade o pleno desenvolvimento do educando, seu preparo para o exercício da cidadania e sua qualificação para o trabalho. (BRASIL, 1996, grifo nosso).

Esse artigo é praticamente uma reprodução, com pequenas mudanças, do artigo 205 da Constituição de 1988, que também fala em "qualificação para o trabalho":

Art. 205. A educação, direito de todos e dever do Estado e da família, será promovida e incentivada com a colaboração da sociedade, visando ao pleno desenvolvimento da pessoa, seu preparo para o exercício da cidadania e sua qualificação para o trabalho. (BRASIL, 1988).

A noção de "qualificação" que aparece nos documentos acima se choca com a idéia de "competência", que perpassa os PCNEM. Isso evidencia um conflito entre os documentos oficiais ou talvez revele que o ensino médio de fato ainda esteja estruturado para dar respostas às demandas da era fordista.

$\mathrm{Na}$ Constituição fica claro que a Educação é um "direito de todos", o que não aparece na LDB, que, por sua vez, fala em "educando", ao passo que a lei maior fala em "pessoa", conceito que tem uma dimensão mais ampla.

A lei máxima afirma: "A educação, direito de todos e dever do Estado e da família [...]"; já a LDB diz: "A educação, dever da família e do Estado [...]". $\mathrm{Na}$ Constituição a educação é antes de tudo dever do Estado, já na LDB, é da família. Sobre essa inversão indaga Saviani (2004, p. 202):

Dir-se-ia que tanto faz, que a ordem dos fatores não altera o produto. Pode ser. Mas não deixa de ser estranho. Se a ordem é indiferente então por que inverter apenas nesse caso, uma vez que nos demais casos se transcreveu pura e simplesmente?

Essa inversão, aparentemente um detalhe sem importância, não deixa de expressar um princípio liberal presente na LDB, ou seja, a precedência da responsabilidade da família sobre a educação dos filhos. Ou seja, o liberalismo está mais presente na LDB do que na Constituição. 
No item "III" do artigo 35 da LDB fica clara a dimensão atitudinal através da qual se procura desenvolver valores e atitudes para uma convivência harmoniosa em sociedade. Dá conta dos pilares "aprender a ser" e "aprender a conviver" do Relatório para a UNESCO.

No item "IV", a LDB procura articular o "aprender a aprender" e o "aprender a fazer", buscando uma ligação entre teoria e prática, uma ligação do conhecimento escolar com a vida, com o cotidiano. Isso vai aflorar nitidamente no PCNEM, na proposta de interdisciplinaridade que articula as disciplinas das três áreas do conhecimento e suas respectivas tecnologias. Isto estaria em consonância com a idéia de "preparação básica para o trabalho".

O problema é que a "preparação básica para o trabalho" não está bem equacionada. Desde o início da década de 1990, houve uma enorme expansão do ensino médio, como mostra a tabela 5. Como se pode observar, essa expansão está fortemente concentrada no sistema de ensino público estadual.

\begin{tabular}{|l||c|c|c|c||c|c|}
\hline \multicolumn{3}{|c|}{ Tabela 5. Brasil: evolução das matrículas no ensino médio } \\
\hline \multirow{2}{|l|}{$\begin{array}{l}\text { Tipos de } \\
\text { instituição }\end{array}$} & total & $\%$ & total & $\%$ & total & $\%$ \\
\hline \hline Pública & 2.753 .324 & 73,0 & 7.933 .713 & 87,8 & 7.838 .086 & 88,0 \\
\hline Federal & 103.092 & 2,7 & 68.651 & 0,8 & 67.650 & 0,8 \\
\hline Estadual & 2.472 .964 & 65,5 & 7.682 .995 & 85,0 & 7.584 .391 & 85,1 \\
\hline Municipal & 177.268 & 4,8 & 182.067 & 2,0 & 186.045 & 2,1 \\
\hline \hline Privada & 1.019 .374 & 27,0 & 1.097 .589 & 12,2 & 1.068 .734 & 12,0 \\
\hline \hline Total & 3.772 .696 & 100 & 9.031 .302 & 100 & 8.906 .820 & 100 \\
\hline
\end{tabular}

Fonte: Sinopse estatística da educação básica - 1991-1995 (INEP, 2003, p. 17); Sinopse estatística da educação básica: censo escolar 2005 (INEP, 2006, p. 81); Sinopse estatística da educação básica 2006 (INEP, 2007a, tab. 1.46). Organizada pelo autor.

De acordo com o INEP (2007a), em 2006 havia 8,9 milhões de estudantes matriculados nas três séries do ensino médio; no ensino superior eram quase 4,7 milhões (ver a tabela 6). Em 2005, o número de ingressantes no ensino médio foi de 3.651.903 e o número de concluintes, de 1.858 .615 (INEP, 2007a). Embora a base de comparação dos estudantes que entraram no sistema não seja o número de 2005, grosso modo pode-se dizer que cerca de metade dos ingressantes no $1^{\circ}$ ano do ensino médio não conclui o $3^{\circ}$ ano, não chega a se formar. Em 2006 ingressaram 
no ensino superior 1.448 .509 estudantes em universidades, centros universitários e faculdades isoladas (INEP, 2007b). Dos que se formaram no ensino médio no ano de $2005,77,9 \%$ ingressaram no ensino superior em 2006. Entretanto, esse índice é bem menor se considerarmos o número de ingressantes no início da educação secundária, já que a taxa de evasão é elevada. A maior parte dos que não ingressam no ensino superior acaba sem nenhuma profissão, especialmente aqueles que nem mesmo concluíram o ensino médio, e a maioria destes estava matriculada em escolas públicas.

\begin{tabular}{|l|c|c|c||c|}
\hline \multicolumn{4}{|c|}{ Tabela 6. Brasil: número de matrículas (em 29 mar. 2006) } \\
\hline Tipos de instituição & $\begin{array}{c}\text { ensino } \\
\text { fundamental }\end{array}$ & $\begin{array}{c}\text { ensino } \\
\text { médio }\end{array}$ & $\begin{array}{c}\text { ensino } \\
\text { profissional }\end{array}$ & $\begin{array}{c}\text { ensino } \\
\text { superior }\end{array}$ \\
\hline \hline Pública & 29.814 .686 & 7.838 .086 & 336.662 & 1.209 .304 \\
\hline Federal & 25.031 & 67.650 & 79.878 & 589.521 \\
\hline Estadual & 11.825 .112 & 7.584 .391 & 233.710 & 481.756 \\
\hline Municipal & 17.964 .543 & 186.045 & 23.074 & 137.727 \\
\hline \hline Privada & 3.467 .977 & 1.068 .734 & 408.028 & 3.467 .342 \\
\hline \hline Total & 33.282 .663 & 8.906 .820 & 744.690 & 4.676 .646 \\
\hline
\end{tabular}

Fonte: Sinopse estatística da educação básica 2006 (INEP, 2007a, tab. 1.18, 1.46, 1.87); Sinopse estatística da educação superior - graduação 2006 (INEP, 2007b, tab. 5.1). Organizada pelo autor.

A "preparação básica para o trabalho" mencionada na lei está assentada apenas em competências gerais, não em formação profissionalizante. Ocorre que a dimensão conceitual da qualificação - títulos e diplomas - ainda é muito importante para a entrada no mercado de trabalho, assim como também sua dimensão social, a existência de profissões regulamentadas e certificadas. Ainda está por se elaborar uma certificação das competências, que só ganham importância para a manutenção do emprego ou para promoções depois que o trabalhador já está inserido no mercado de trabalho.

Isso é um dos fatores que explicam porque a taxa de desemprego é maior entre os estudantes que concluíram o ensino fundamental e chegaram ao ensino médio em comparação com a base e o topo da estrutura educacional (ver tabela 7). No momento de procurar trabalho esses estudantes têm maior expectativa e maior exigência em relação ao emprego do que os que permaneceram menos tempo na 
escola, entretanto, não têm o mesmo preparo, inclusive do ponto de vista da profissionalização, na comparação com os que têm mais anos de estudo.

\begin{tabular}{|c|c|}
\hline \multicolumn{2}{|c|}{$\begin{array}{c}\text { Tabela 7. Brasil: taxa de desemprego por anos de } \\
\text { estudo (2005) }\end{array}$} \\
\hline \hline Anos de estudo & desemprego (\%) \\
\hline 0 a 5 & 8,3 \\
\hline 6 a 9 & 15,0 \\
\hline 10 a 12 & 12,0 \\
\hline 13 ou mais & 5,4 \\
\hline \hline Desemprego total & 11,0 \\
\hline
\end{tabular}

Fonte: Anuário da qualificação social e profissional 2007 (DIEESE, 2007, p. 112).

A situação evidenciada por esses números pode ter contribuído para a diminuição do número de matrículas no ensino médio (ver tabela 5), depois de um crescimento constante por muitos anos. Em 2006 o número total de estudantes matriculados no ensino médio (público e privado) reduziu-se em 1,4\% em comparação com o de 2005 (INEP, 2007a). Entretanto, essa redução foi desigual no território nacional: na região sudeste a queda foi de 4,5\% e em São Paulo, estado mais rico da federação, foi de 5,2\% (maior redução verificada). Pode ter contribuído também para essa diminuição a dificuldade das famílias em arcar com as despesas escolares, já que a redução das matrículas na escola privada foi de $2,6 \%$, enquanto que na pública foi de 1,2\%. É lamentável que muitos jovens possam estar concluindo que não vale a pena o esforço de permanecer por mais tempo na escola.

A sociedade do conhecimento, como indicam os documentos das reformas, exige estudantes com uma formação geral sólida, ancorada em novas competências e habilidades, e isso deve ser assegurado pela educação básica, como pregam os documentos oficiais, mas os trabalhadores precisam ter alguma profissão para se inserirem no mercado de trabalho. Como sugerem os números acima, as demandas do mundo atual exigem também mais tempo de permanência na escola. Só assim os estudantes se converterão em trabalhadores e cidadãos preparados e, dentro das possibilidades e anseios de cada um, poderão escolher (embora saibamos que muitas vezes isso não é bem uma escolha) se vão para 
universidade ou se vão exercer uma profissão técnica de nível médio, o que, muitas vezes, não são opções excludentes, mas complementares. Muitos estudantes precisam trabalhar para custear seus estudos. De qualquer forma, apesar do discurso das competências estar tão em voga, não se pode abrir mão da formação profissional, especialmente de sua dimensão conceitual.

Nesse ponto a nova orientação avançou em relação à situação anterior, em que o ensino técnico comprometia a formação geral do educando. O documento das DCNEM prevê que a articulação entre o ensino médio e a educação profissional deverá contemplar a formação geral e a preparação para o trabalho:

- estudos estritamente profissionalizantes, independentemente de serem feitos na mesma ou em outra instituição, concomitantemente ou posteriormente ao Ensino Médio, deverão ser realizados em carga horária adicional às 2.400 previstas pela LDB como mínimas. (BRASIL, 2002a, p. 101).

Isso foi referendado pelo Decreto n. $5154^{54}$, de 23 de julho de 2004, que regulamenta o $\S 2^{\circ}$ do art. 36 e os arts. 39 a 41 da LDB 9394/96 ao prever que a educação profissional técnica pode ser subseqüente, concomitante ou integrada ao ensino médio regular e, nesse caso, a formação técnica deverá exceder a carga de 800 horas anuais ou de 2400 horas do curso total (BRASIL, 2004b). Aí está uma grande contradição: só a "preparação básica para o trabalho" não qualifica 0 estudante, como prescreve a Constituição e a LDB, para entrar no mercado, que exige além de competências gerais, o domínio de alguma profissão e especialmente um título. Por outro lado, voltar ao sistema antigo oriundo da LDB 5692/71, que priorizava as matérias técnicas em detrimento das disciplinas regulares, também não é indicado porque vai contra as necessidades do novo regime de acumulação e das novas demandas da cidadania. Além disso, o aluno que trabalha o dia inteiro, o que mais precisaria do curso técnico, não pode fazer o curso profissionalizante porque 0 ensino médio noturno já toma todo o tempo que lhe sobra após a jornada de trabalho.

54 Este decreto, elaborado no Governo Luiz Inácio Lula da Silva, revoga o Decreto n. 2208 de 17 de abril de 1997, feito sob o Governo Fernando Henrique Cardoso. O decreto anterior acabava com o ensino técnico integrado ao ensino médio, como se depreende de seu artigo $5^{\circ}$ : “A educação profissional de nível técnico terá organização curricular própria e independente do ensino médio, podendo ser oferecida de forma concomitante ou seqüiencial a este.” (BRASIL, 1997). 
Diante desse impasse, na prática, o que vemos é o estabelecimento de uma "nova" versão para os "tradicionais" dois percursos. O ensino médio das escolas privadas, voltado majoritariamente para a classe média, é propedêutico: a maioria dos estudantes pertencentes a essa camada social estuda visando unicamente à universidade. Já o ensino médio da rede pública, voltado majoritariamente para estudantes de menor renda, devido à má qualidade do ensino ministrado em grande parte das escolas, não prepara para a universidade nem para o mercado de trabalho.

Não há dados disponíveis para todo o universo do ensino médio brasileiro, portanto, um indicador do despreparo e conseqüentemente da exclusão de grande parte dos estudantes das escolas públicas pode ser percebido pela origem dos inscritos no vestibular da FUVEST (tabela 8) e dos matriculados na Universidade de São Paulo (tabela 9). Essa amostra, apesar de limitada em termos de Brasil, é muito significativa, pois a FUVEST é o maior exame vestibular do país.

\begin{tabular}{|l|c|c|}
\hline \multicolumn{3}{|c|}{$\begin{array}{c}\text { Tabela 8. Vestibular FUVEST 2007: inscritos na } \\
\text { prova* }\end{array}$} \\
\hline $\begin{array}{l}\text { Em que tipo de escola o candidato } \\
\text { realizou o ensino médio }\end{array}$ & Total & $\%$ \\
\hline Só em particular & 82.032 & 57,9 \\
\hline Só em pública estadual ou municipal & 49.340 & 34,8 \\
\hline Maior parte em particular & 3.735 & 2,6 \\
\hline Maior parte em pública & 2.629 & 1,8 \\
\hline Só em pública federal & 1.568 & 1,1 \\
\hline Em supletivo ou madureza & 1.176 & 0,8 \\
\hline Metade em pública, metade em particular & 600 & 0,4 \\
\hline No exterior (qualquer tipo de escola) & 485 & 0,3 \\
\hline Total & 141.565 & $99,7^{* *}$ \\
\hline
\end{tabular}

FUVEST - Fundação Universitária para o Vestibular. Vestibular 2007. Questionário de avaliação sócio-econômica. Disponível em: <www.fuvest.br/vest2007/estat/estat.stm>. Acesso em: 7 out. 2008.

*Dos 142.656 candidatos inscritos no exame vestibular 2007, 141.565 responderam o questionário de avaliação sócio-econômica. **Não completa os $100 \%$ porque a Fuvest não arredondou os números.

Tabela 9. Vestibular FUVEST 2007: convocados para matrícula* 


\begin{tabular}{|l|c|c|}
\hline $\begin{array}{l}\text { Em que tipo de escola o ingressante } \\
\text { realizou o ensino médio }\end{array}$ & Total & $\begin{array}{c}\text { Percentu } \\
\text { al }\end{array}$ \\
\hline Só em particular & 8.162 & 71,6 \\
\hline Só em pública estadual ou municipal & 2.360 & 20,7 \\
\hline Só em pública federal & 352 & 3,0 \\
\hline Maior parte em particular & 267 & 2,3 \\
\hline Maior parte em pública & 172 & 1,5 \\
\hline Em supletivo ou madureza & 33 & 0,2 \\
\hline Metade em pública, metade em particular & 31 & 0,2 \\
\hline No exterior (qualquer tipo de escola) & 20 & 0,1 \\
\hline Total & 11.397 & $99,6^{\star *}$ \\
\hline
\end{tabular}

FUVEST - Fundação Universitária para o Vestibular. Vestibular 2007. Questionário de avaliação sócio-econômica. Disponível em: <www.fuvest.br/vest2007/estat/estat.stm>. Acesso em: 7 out. 2008.

*Dos 11.502 candidatos chamados para a primeira matrícula, 11.397 responderam a questão.

**Não completa os $100 \%$ porque a Fuvest não arredondou os números.

Como se constata pelos números da tabela, a maioria dos candidatos ao exame vestibular da FUVEST e especialmente dos ingressantes na Universidade de São Paulo é oriunda de escolas privadas. Essa realidade, com pequeno desvio, deve se reproduzir na maioria dos exames vestibulares das universidades públicas brasileiras (federais e estaduais). Ou seja, o ensino médio público não prepara para os vestibulares mais concorridos do país, nem para o mercado de trabalho, quiçá para a cidadania, como propõe a Constituição e a LDB 9394/96.

De acordo com o INEP (2007a), em 2006 havia 744.690 matrículas em cursos de educação profissional. Apesar de estar em expansão, esse número ainda é pequeno, continua havendo uma grande escassez de técnicos no mercado de trabalho. Para agravar essa carência, até mesmo muitas escolas técnicas públicas - as Escolas Técnicas Estaduais (ETE) e sobretudo os Centros Federais de Educação Tecnológica (CEFET), entre as melhores do país - desvirtuando sua função, historicamente, têm tido na prática um papel propedêutico. Como são concorridas, em geral os estudantes que lá ingressam são mais bem preparados muitos deles oriundos da classe média - e, aproveitando-se da boa formação oferecida por essas escolas, muitos acabam indo para a universidade, não exercendo a profissão técnica para a qual se formaram. Na verdade, muitos nem chegavam a se formar, nem mesmo concluíam o quarto ano que os capacitaria a ser técnicos; ao concluírem $\circ 3^{\circ}$ ano do ensino médio e de posse do certificado, 
prestavam o exame vestibular para um curso superior. Dessa forma, muitos estudantes pobres não obtinham uma formação profissional de nível médio porque não conseguiam entrar nessas escolas, enquanto muitos oriundos da classe média acabavam estudando para uma profissão que nunca exerceriam. Ou seja, a seleção nas escolas privadas de nível médio é pelo critério socioeconômico e nas escolas de formação profissional média públicas é pelo critério meritocrático. É sabido que meritocracia está intimamente ligada ao aspecto socioeconômico. Como afirma Frigotto (2003, p. 162):

Há casos em que há uma vaga para 50 candidatos. As evidências estatísticas mostram que o argumento de que é para formarem-se técnicos de nível médio necessários à incorporação ao mercado de trabalho é falso para o grupo social que freqüenta as escolas técnicas federais.

Tentando mudar esse quadro, atualmente os CEFET definiram que o estudante que entrar no ensino médio profissionalizante integrado terá necessariamente de fazer o curso em 4 anos, cumprindo as 2400 horas do ensino médio básico mais as horas correspondentes ao ensino profissionalizante. Somente ao final o aluno obterá o certificado de conclusão do ensino médio e o diploma do curso técnico correspondente.

Enquanto isso, os estudantes da maioria das escolas públicas regulares continuam com déficit de formação, de oportunidades e, portanto, de cidadania. Essas contradições são resultantes do fato de que a indefinição do ensino médio, apesar de ter sido resolvida na lei, permanece na realidade. Tal situação, na prática, é um mecanismo perverso de produção e reprodução de desigualdade social.

Poder-se-ia dizer, parafraseando Saviani (2004, p. 7), que com isso hoje vigora o seguinte slogan: terminalidade ideal para nossos filhos e terminalidade possível para os filhos dos outros. Deve ser registrado, entretanto, que esse cenário está mudando.

Diversos governos estaduais, especialmente do nordeste, estão empenhados em ampliar a educação profissional no país, de forma que em 2006 as matrículas nas escolas profissionais em toda a rede - pública (federal, estadual e municipal) e privada - subiram para 744.690 (INEP, 2007a). Houve um significativo 
acréscimo de 5,3\% em relação aos 707.263 do ano anterior (INEP, 2006). Na rede pública estadual o aumento foi de $24,3 \%$.

O governo federal, por sua vez, em diversas oportunidades tem declarado que é prioritária a construção de novas escolas técnicas, como no discurso do presidente Luiz Inácio Lula da Silva (PT), durante a sanção da lei que fixou o piso nacional do magistério. Depois de mais uma vez constatar que em 100 anos foram construídas apenas 140 escolas técnicas no Brasil, fez uma crítica velada ao seu antecessor, Fernando Henrique Cardoso (PSDB) e prometeu mais 214 até 2010:

Exatamente nesse período se fez um decreto proibindo o governo federal de assumir a responsabilidade pelo ensino técnico profissional. Nós revogamos o decreto, fizemos outro ${ }^{55}$ e temos um compromisso, que eu quero que vocês anotem: até o dia 31 de dezembro de 2010 queremos ter mais 214 escolas técnicas funcionando neste país. (BRASIL, 2008).

Isso evidencia um novo enfoque para o ensino técnico profissional de nível médio no país. Entretanto, além da ampliação das escolas técnicas, falta melhorar - e muito - o ensino médio público regular oferecido aos estudantes brasileiros. Para que, com isso, os estudantes mais pobres, que são maioria, cheguem ao final da educação secundária e possam pensar em um curso superior com possibilidades idênticas aos estudantes oriundos das escolas privadas.

55 O presidente da República se refere ao Decreto 5154/04 que revogou o 2208/97. 


\section{O SiSTEMA EDUCATIVO ESPANHOL E AS MUdANÇAS NA EDUCAÇÃo SECUNDÁRIA}

Para compreendermos o funcionamento do atual sistema educativo espanhol e os porquês da mais recente reforma regulada pela Ley Orgánica de Educación (LOE) aprovada em 2006, é necessário voltarmos ao sistema educativo criado pela Ley de Ordenación General del Sistema Educativo (LOGSE) de 1990, já que a estrutura do sistema atual é herdada daquela reforma. Entretanto, não é possível contextualizar histórica e politicamente a LOGSE sem fazermos referência à Ley General de Educación (LGE) de 1970 e as mudanças políticas, sociais, econômicas e tecnológicas que aconteceram nesse lapso de vinte anos entre elas.

Porém, o marco fundamental para a transformação da Espanha no país que é hoje, não apenas no campo educacional, mas no político, no econômico e no social, foi sem dúvida a promulgação da Constituição de 1978, fato que marca a transição da ditadura franquista para a democracia parlamentar. É a Constituição de 1978 que orientará as leis que vão implementar as reformas educacionais até hoje em dia. Por isso, darei particular ênfase à Ley Orgánica Reguladora del Derecho a la Educación (LODE), de 1985, que apesar de modificada ainda permanece em vigor; à LOGSE, que embora revogada é dela que descende diretamente o atual sistema de ensino espanhol; e à $L O E$, a última reforma feita na Espanha. Nessa retomada serão enfatizadas as mudanças estruturais e curriculares, especialmente as ocorridas no ensino secundário.

\section{Antecedentes: Ley General de Educación (LGE)}


Depois de um longo período sendo regulada pela Ley Moyano ${ }^{56}$ de 1857 , a Espanha aprova uma nova lei para orientar a mudança em seu sistema educativo: a Ley 14/1970 General de Educación y Financiamiento de la Reforma Educativa, de 4 de agosto de 1970, mais conhecida como LGE.

Essa lei foi elaborada na gestão do ministro Villar Palasi ${ }^{57}$, que compunha a tendência democrata cristã do governo do ditador Francisco Franco. Na época de sua publicação, a Espanha vinha passando por uma rápida transformação demográfica e socioeconômica, para a qual a lei buscava dar respostas. O país passava por um rápido crescimento demográfico, fortes migrações, a urbanização era crescente e o processo de desenvolvimento econômico, acelerado - a industrialização crescia a taxas elevadas, demandando maiores contingentes de mão-de-obra qualificada. Nesse contexto aumentava a pressão por maiores níveis de escolarização, especialmente por parte das classes médias em expansão (ROZADA, 2002; TERRÓN, 2006). Havia entre a população uma generalizada aspiração por uma melhoria das condições de vida e as expectativas de mobilidade social eram depositadas na Educação (CAPEL et al., 1984). Na interpretação de Rozada:

[...] el punto de inflexión en el sistema de enseñanza, a partir del cual se van desarrollando los aspectos básicos del modelo que hoy tenemos, habría que situarlo en la Ley General de Educación (LGE) de 1970, la cual a su vez constituye la respuesta legislativa a la creciente presión social que las clases medias en desarrollo venían ejerciendo sobre el sistema escolar desde los años 50 del pasado siglo XX. (2002, p. 17)

Terrón (2006, p. 129) afirma que a LGE "fue un intento de respuesta global desde el sistema a los profundos cambios que se estaban produciendo en el país, absolutamente alejado de aquel que había aprobado la todavía vigente pero anacrónica ley Moyano".

Deve-se acrescentar, segundo Terrón (2006), os "conselhos" dos representantes do Banco Mundial (BIRD) e da UNESCO para que houvesse uma

\footnotetext{
56 A Ley de Instrucción Pública, de 9 de setembro de 1857, mais conhecida como Ley Moyano, foi elaborada quando Claudio Moyano Samaniego (1809-1890) era ministro do Fomento. Nessa época a Espanha vivia sob o Reinado de Isabel II e era governada pela União Liberal, tendo como chefe de governo Ramón María Narváez.

57 Villar Palasí, como era mais conhecido José Luis Villar Palasí (1922-), foi Ministro da Educação de 1968 a 1973.
} 
expansão do sistema educacional espanhol, em sintonia com o estágio do desenvolvimento econômico do país naquele momento. Como nos lembrou Beltrán Duarte (2000), a LGE também foi influenciada pela teoria do capital humano, muito em voga na época.

Nesse contexto, evidenciando os desafios a serem enfrentados, assim se inicia o preâmbulo da $L G E$ :

El sistema educativo nacional asume actualmente tareas y responsabilidades de una magnitud sin precedentes. Ahora debe proporcionar oportunidades educativas a la totalidad de la población para dar así plena efectividad al derecho de toda persona humana a la educación y ha de atender a la preparación especializada del gran número y diversidad de profesionales que requiere la sociedad moderna. [...]

El marco legal que ha regido nuestro sistema educativo en su conjunto respondía al esquema ya centenario de la Ley Moyano. Los fines educativos se concebían de manera muy distinta en aquella época y reflejaban un estilo clasista opuesto a la aspiración, hoy generalizada de democratizar la enseñanza. (ESPAÑA, 1970, p. 12525).

A conclusão do preâmbulo é otimista e contundente: "La reforma educativa es una revolución pacífica y silenciosa, pero la más eficaz y profunda para conseguir una sociedad más justa y una vida cada vez más humana." (ESPAÑA, 1970, p. 12525). Entretanto, falsa e irônica. Falsa porque, como vimos, não é possível reformar o sistema educativo e provocar grandes transformações sem reformar a sociedade. Irônica porque ao final do documento publicado no Boletim Oficial del Estado (BOE) está assinado em letras maiúsculas "FRANCISCO FRANCO". Ou seja, essa lei foi elaborada sob uma ditadura das mais violentas da História, a do generalíssimo Francisco Franco (1939-1975). Nunca deve ser esquecido que nos primórdios dessa ditadura milhares de professores foram perseguidos $^{58}$, quando o regime empenhava-se em abortar a incipiente reforma iniciada pelos republicanos e desmantelar o sistema educativo, então em

58 De acordo com Terrón (2006), entre 1936 e 1942 cerca de 25\% dos professores do magistério oficial receberam algum tipo de sanção: "En virtud de las cuales seis mil maestros y maestras fueron separados forzosamente de la enseñanza, mientras que algo más de tres mil fueron suspendidos de empleo y sueldo por períodos variables de tiempo; también alrededor de seis mil perdieron su plaza al ser trasladados forzosamente de localidad; la inmensa mayoría de todos los anteriores fueron inhabilitados para cargos directivos, pero además casi dos mil recibieron esa sanción exclusiva; finalmente cerca de dos mil docentes sufrieron alguna de las restantes sanciones posibles, (jubilaciones forzosas, expedientes de disciplina..." (MORENTE, 1997, p. 426-7 apud TERRÓN, 2006, p. 124-5). 
construção, baseado numa escola única, pública, laica e revolucionária (aqui, de fato seria, especialmente considerando a sociedade espanhola da época).

A LGE, segundo Rozada (2002), pode ser considerada o marco inicial do atual "modelo de ensino tecnocrático" na Espanha. Lerena (1999) chama de "liberal" o modelo que vai da Ley Moyano até a LGE e de "tecnocrático ou tecnicista" o modelo vigente a partir de então. Cuesta (1997 apud ROZADA, 2002) chama de "modo de educação tradicional-elitista" o modelo educacional anterior a LGE e de "modo de educação tecnocrático de massas", o posterior, vigente até hoje. Embora as leis posteriores a LGE continuassem a ser orientadas por um interesse técnico, especialmente em sua dimensão curricular, o contexto em que surgiram foi outro, portanto, têm diferenças que precisam ser apontadas. A LODE, por exemplo, criada em 1985 e em vigor até hoje, teve um caráter mais democrático: entre outras coisas, aumentou a participação da comunidade na gestão e no controle dos centros escolares. Assim, o modelo tecnocrático da LGE é mais controlador, mais autoritário e mais conservador que o das leis elaboradas no período democrático, e essas diferenças não são matizadas pelas classificações acima.

Lerena (1999) faz uma longa lista das características do modelo tecnocrático com relação ao alunado, ao produto que a prática educativa escolar deve obter e, finalmente, com relação à própria prática educativa. Com relação a esta, afirma que há um "reforzamiento de la ideología economicista y tecnicista acerca de las funciones sociales del sistema de enseñanza, en virtud de la cual se concibe a este como una empresa de producción, ante la que se reclama rendimiento y eficacia técnica." (LERENA, 1999, p. 717). Esse é apenas um dos itens de sua longa lista, mas é a definição mais acabada do momento em que emerge o sistema tecnicista na escola. De fato, se recordarmos a síntese do quadro 1 , fica evidente que a $L G E$ foi claramente orientada pelo interesse técnico. Isso tinha tudo a ver com o momento em que foi elaborada, época em que o tecnicismo estava em alta e, no caso específico espanhol, em que o país vivia sob a uma ditadura. Como qualquer outra, a ditadura Franquista primava pelo controle e a Educação evidentemente não escapou dessa lógica. 
Nesse sentido, não foi a $L G E$, ou qualquer outra reforma do período, que impôs o tecnicismo, mas ao contrário, foi o tecnicismo que impôs a $L G E$ e outras leis contemporâneas a ela em outros países, como a 5692/71 no Brasil. A LGE foi fruto de um momento do capitalismo, marcado pelo regime de acumulação fordista (HARVEY, 1993), foi uma busca de adaptação a esse momento. Como diz Lerena (1999, p. 715):

Los procesos sociales no esperan a los decretos ministeriales para producirse; lo que llamamos sistema de enseñanza tecnocrático no es un producto de los va y viene ministeriales, no ha sido un invento o creación de la Ley General de Educación (1970); ésta no ha hecho más que empezar a reconocerlo y tratar de regularlo y consagrarlo en una determinada configuración, más o menos acabada, más o menos paralela a la correspondiente a otros sistemas en igual fase y en otros países.

Apesar de tecnicista e de ser elaborada no seio de uma ditadura, a $L G E$ deu um grande impulso para a democratização do acesso ao ensino básico ao definir como obrigatória e gratuita a Educación General Básica (EGB) em oito séries únicas dos 6 aos 14 anos (fundiu os antigos níveis de primária - elementar e superior - e de bachillerato elementar). De acordo com Vilanovas Ribas e Moreno Julià (1992), quando da aprovação dessa lei a taxa de analfabetismo na Espanha ainda era de $9 \%{ }^{59}$, o que correspondia a 2,4 milhões de pessoas.

No ensino médio, criou o Bachillerato Unificado Polivalente (BUP) com caráter propedêutico, mas sem o elitismo e o academicismo do antigo bachillerato, de forma que pudesse também preparar para a inserção no mercado de trabalho. Estava organizado em torno de um núcleo fundamental de disciplinas comuns (às quais se poderia agregar optativas) e matérias obrigatórias de caráter profissionalizante (embora optativas por setor: indústria, agricultura, comércio, administração ou belas artes). Com isso se pretendia formar alunos polivalentes que tanto poderiam ir à universidade quanto ao mercado de trabalho. A lei abria a possibilidade de que no futuro o BUP também fosse gratuito. Quem quisesse e pudesse seguir estudando (já que não era gratuito) em direção ao ensino superior teria que fazer o Curso de Orientación Universitária (COU) antes de prestar as

59 Son consideradas analfabetas aquellas personas de diez y más años de edad que no saben escribir (se incluyen, pues, las personas semianalfabetas; aquellas que sólo saben leer) (VILANOVAS RIBAS;

MORENO JULIÀ, 1992, p. 166). 
Pruebas de Acceso a la Universidad (PAU). Os estudantes que necessitassem ingressar mais cedo no mercado de trabalho e quisessem ter uma formação profissional mais específica tinham como opção de fazer, em vez do BUP, o curso de Formación Profesional de nível médio 1 e 2 (o de nível 1 era gratuito, o que, nesse caso, estendia a gratuidade até os 16 anos). O quadro 4 mostra a estrutura do sistema educativo criado pela $L G E$. 


\section{Quadro 4. Sistema Educativo LGE}

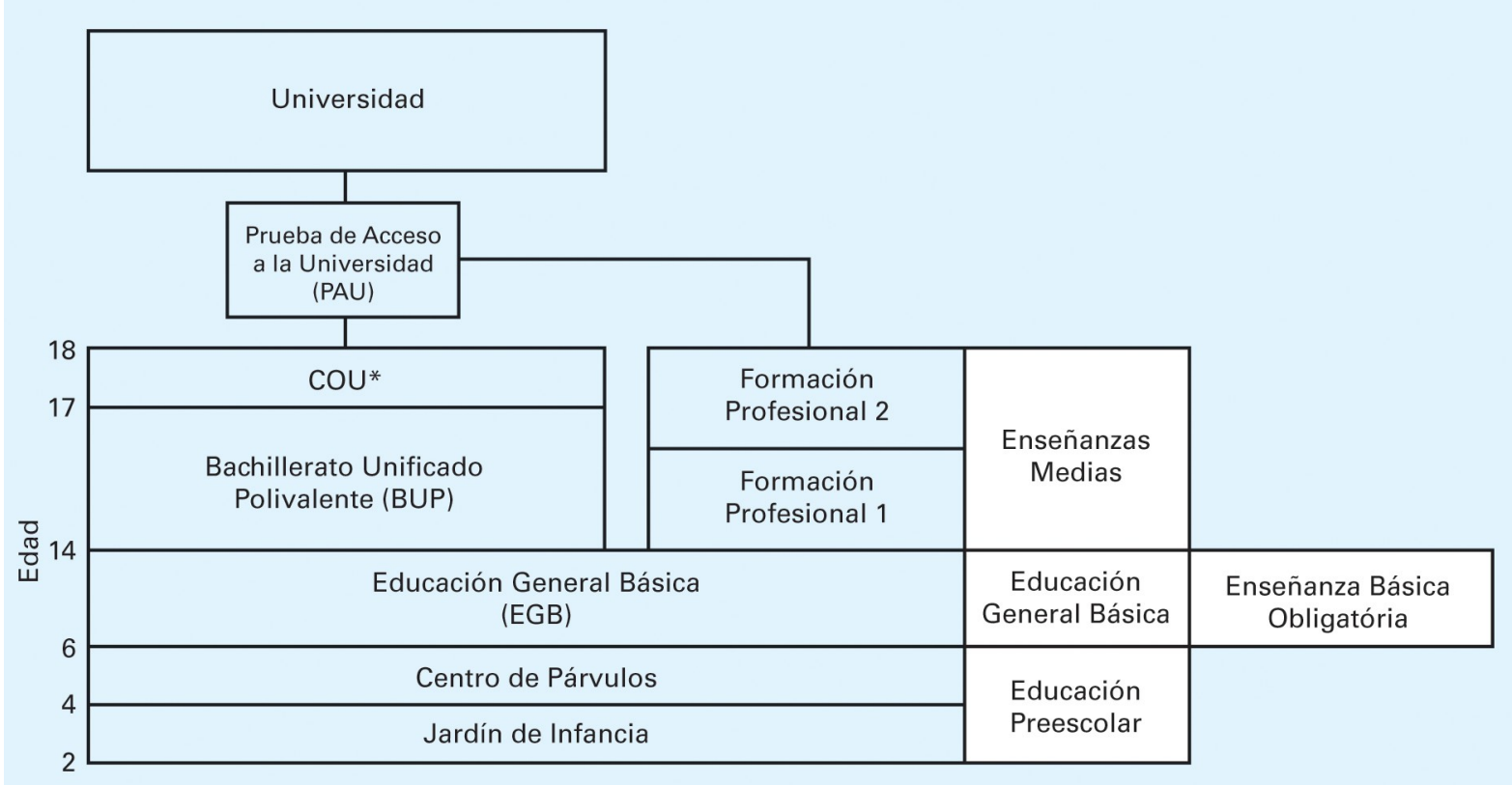

Fonte: Coll (1992, p. 12).

*Curso de Orientación Universitaria.

Com o passar do tempo, a Formação Profissional foi ficando desprestigiada e paralelamente o bachillerato foi ganhando contornos academicistas e seletivos como no passado, a ponto de perder o complemento "unificado e polivalente". Enfim, foi ganhando cada vez mais o caráter de um curso propedêutico, que viria a se consolidar nas futuras reformas.

Apesar das mudanças socioeconômicas, politicamente o país permanecia imutável. Sob a ditadura franquista, o Estado mantinha-se centralizado e autoritário. Isso, como vimos, impregnou a $L G E$, já que a Educação naquele regime tinha um forte caráter de controle ideológico, político e socioeconômico. O currículo, por exemplo, era altamente centralizado e prescrevia com grande detalhe o que deveria ser ensinado e avaliado, deixando, portanto, pouca margem de manobra aos centros escolares e aos professores para lidar com a diversidade de interesses, motivações e capacidades (COLL, 1992). Segundo Cesar Coll, nesse contexto, as editoras de livros didáticos tiveram um papel decisivo como agentes de desenvolvimento curricular.

As contradições e os conflitos da sociedade espanhola de então se materializaram nitidamente na forma como essa lei foi recebida e avaliada. A 
extrema direita temia que os interesses do Banco Mundial (BIRD) e da UNESCO disseminassem o espírito ateu e "materialista" na sociedade espanhola. A esquerda via a lei como um instrumento a serviço do capital, voltada para a preparação de produtores e consumidores e, pior, gestada no seio de um regime ditatorial, portanto, sem legitimidade. Além disso, identificava um caráter classista na lei pelo fato de que não tinha uma previsão orçamentária para a ampliação das vagas acompanhada da melhoria da qualidade, o que prejudicaria os setores mais vulneráveis da sociedade. A igreja, por sua vez, temerosa de que a Educação fosse de fato considerada um "serviço público fundamental", como constava no artigo $3^{\circ}$ da $L G E$, apelando ao princípio da obrigatoriedade e da gratuidade vigente para a $E G B$, pressionava para que se aumentasse a subvenção estatal à escola privada. Com isso inaugurou-se o sistema das escolas subvencionadas, paralelamente ao sistema público, que, como lembra Terrón (2006), seria legitimado mais tarde pela Ley Orgánica Reguladora del Derecho a la Educación (LODE), com a criação dos centros concertados.

\section{Ley Orgánica Reguladora del Derecho a la Educación (LODE)}

Somente após o desaparecimento de Franco, em 20 de novembro de 1975, teve início o processo de abertura política na Espanha. Com a morte do ditador, Juan Carlos $I^{60}$ torna-se Rei da Espanha, herda o cargo de chefe de Estado e dá início à transição democrática. A chamada Transición Española estende-se até a entrada em vigor da Constituição, em 29 de dezembro de 1978. A nova lei maior culmina o processo de transição e marca o início do Estado democrático de direito na Espanha, apesar de tentativas regressivas, como o golpe militar de 1981. Essa

60 No final dos anos 1960, Francisco Franco, com seu status oficial de "regente" da monarquia suspensa, nomeou o então príncipe Juan Carlos, neto do último rei da Espanha, como seu sucessor. Esse ato, na prática, significava a restauração da monarquia no país. Em 22 de novembro de 1975, dois dias depois da morte de Franco, Juan Carlos foi coroado rei (JUDT, 2008). 
intentona se frustrou diante da rejeição do rei Juan Carlos I às exigências dos conspiradores e de seu firme discurso em defesa da Constituição (JUDT, 2008).

A Constituição de 1978 abre caminho para a consolidação da democracia e da cidadania no país e também para o processo de descentralização políticoadministrativo. Isso redunda na criação do Estado das Autonomias, através do qual as 17 Comunidades Autônomas passam a gozar de significativa autonomia frente ao poder central. Essas mudanças provocarão impactos importantes no plano político, social, econômico e também no educacional, como veremos.

Em 15 de junho de 1977 foram realizadas as primeiras eleições diretas para o parlamento depois da derrocada do regime franquista. Essas eleições foram vencidas pela Unión de Centro Democrático (UCD). Essa coalizão aglutinava diversas correntes políticas centristas - social-democratas, democrata-cristãos e liberais - sob a liderança de Adolfo Suárez ${ }^{61}$ e obteve a maioria no parlamento. $O$ Partido Socialista Obrero Español (PSOE $)^{62}$, de esquerda, recém-legalizado, ficou em segundo lugar (GARCíA DE CORTÁZAR; GONZÁLEZ VESGA, 1994; JUDT, 2008).

O período do governo da $U C D$ foi marcado pela necessidade de adequação do sistema educacional à nova realidade democrática e também ao novo estatuto das autonomias. Por outro lado eram patentes o esgotamento da reforma orientada pela $L G E$ e a crescente aversão a tudo que fosse autoritário. Também na Educação foi um período de transição: houve um grande impulso à democratização e à inovação, era baixa a formalização e a burocratização do sistema educativo. Foi um momento marcado por fraca regulamentação estatal e grande liberdade de inovação por parte dos professores em seu labor diário. Nesse contexto ganharam

${ }^{61}$ Adolfo Suárez González assumiu a presidência do Governo por indicação do rei Juan Carlos (substituiu a Carlos Arias Navarro, herdado do regime Franquista), de junho de 1976 a junho de 1977, quando ocorreram as primeiras eleições diretas desde 1936. A vitória da $U C D$ nas urnas garantiu sua maioria no parlamento e a indicação de Adolfo Suárez ao cargo de chefe de Governo. Ele foi um dos principais responsáveis pelas negociações que levariam à elaboração da Constituição de 1978. Permaneceu no cargo até 1981, quando renunciou e foi substituído por Leopoldo Calvo Sotelo (JUDT, 2008).

62 O PSOE é o partido mais antigo da Espanha, fundado por intelectuais e trabalhadores em 1879. Com a chegada de Franco ao poder em 1939, o partido foi posto na clandestinidade. A legalização do PSOE ocorre em fevereiro de 1977. Com a vitória da $U C D$ nas eleições daquele ano, os socialistas, segundo colocados, ficam na oposição. (Partido Socialista Obrero Español. Disponível em: <www.psoe.es>. Acesso em: 9 out. 2008). 
força os Movimientos de Renovación Pedagógica $(M R P)^{63}$, um período de grande protagonismo dos professores, especialmente dos inovadores. (ROZADA, 2002).

A UCD governou a Espanha até 1982, quando diante do agravamento da crise econômica e da incapacidade de se equilibrar entre a direita e a esquerda, foi dizimada politicamente. Nas eleições daquele ano obteve apenas dois assentos no parlamento e no ano seguinte seria dissolvida. Com isso as correntes de centrodireita, como os liberais, se integraram à Alianza Popular ${ }^{64}$, que em 1989 se transformaria no Partido Popular, e as correntes de centro-esquerda, como os social- democratas, ao PSOE. (GARCÍA DE CORTÁZAR; GONZÁLEZ VESGA, 1994; JUDT, 2008).

Nas eleições de 1982 o PSOE conquista a maioria absoluta no parlamento, tanto no Congresso dos deputados como no Senado, e com isso assume como chefe de Governo o primeiro-ministro Felipe González Márquez, líder do partido desde sua legalização, que ficaria 14 anos no poder. A Alianza Popular conseguiu cerca de um quarto dos parlamentares (JUDT, 2008). A partir daí começa a se delinear o sistema bipartidário existente até hoje na Espanha, com o PSOE aglutinando as forças de centro-esquerda e o $P P$, as de centro-direita. Atualmente os dois partidos têm quase $90 \%$ dos parlamentares no Congresso (COMISIÓN EUROPEA, 2008).

Com a consolidação da democracia e a chegada de um partido de esquerda ao poder $^{65}$, iniciou-se um período de profundas mudanças políticas na Espanha.

Os anos 1980 foram marcados pela experimentação e conseqüentemente pela diversidade de propostas pedagógicas. Nesse momento houve uma grande proximidade entre os MRP e o governo central, a ponto de muitos de seus membros

63 Um dos MRP pioneiros foi a Escola de Mestres Rosa Sensat, criada no ano de 1965, em Barcelona, e que em 1980 se transformou na Associació de Mestres Rosa Sensat (MATA I GARRIGA, 1985). A maioria dos MRP surgiu no início do atual período democrático, momento de maior protagonismo desses grupos.

64 A Alianza Popular foi criada em 1977 como uma federação de partidos conservadores sob a liderança de Manuel Fraga. Em 1989, em seu IX Congresso Nacional, tentando articular forças frente à maioria absoluta do PSOE no parlamento, os líderes da Federación de Partidos de Alianza Popular decidem refundar a agremiação e mudam seu nome para Partido Popular (PP). (Partido Popular. Disponível em: $<$ www.politica21.org/marco.htm>. Acesso em: 9 out. 2008).

65 A última vez que isso ocorrera foi nas eleições de 1936, na qual ganhou a Frente Popular, uma aliança entre socialistas e republicanos (JUDT, 2008). 
participarem da administração pública. O governo estimula a inovação e alguns grupos de renovação pedagógica passam a produzir material didático para o Ministério da Educação. Muitos acreditaram que sob o governo socialista a Educação seria de fato democratizada, porém a Ley Orgánica Reguladora del Derecho a la Educación (LODE) mostrou que, como afirma Rozada (2002), a democracia cada vez mais se aproximava de seu par, o mercado. Não houve a implantação de um sistema de ensino público, único, laico e plenamente gratuito, bandeira histórica dos socialistas.

A $L O D E$ faz uma interpretação bastante ampla do princípio da "liberdade de ensino" que consta no artigo 27.1 da Constituição Espanhola e legitima a rede dual (pública e privada), a doble red ${ }^{66}$, como chamam os espanhóis, no sistema educativo do país. Fazendo referência aos princípios constitucionais, o preâmbulo da $L O D E$ defende que:

En estos principios debe inspirarse el tratamiento de la libertad de enseñanza, que ha de entenderse en un sentido amplio y no restrictivo, como el concepto que abarca todo el conjunto de libertades y derechos en el terreno de la educación. Incluye, sin duda, la libertad de crear centros docentes y de dotarlos de un carácter o proyecto educativo propio, que se halla recogida y amparada en el Capitulo III del Titulo I. Incluye, asimismo, la capacidad de los padres de poder elegir para sus hijos centros docentes distintos de los creados por los poderes públicos, así como la formación religiosa y moral que esté de acuerdo con sus convicciones, tal como se recoge en el artículo 4. (ESPAÑA, 1985, p. 21015).

Para as pessoas que, com o processo de abertura política e a chegada dos socialistas ao poder, acreditaram ser possível a implantação de um sistema de ensino público, único, laico e plenamente gratuito (e muitas delas lutaram para que isso se concretizasse), as palavras acima são extremamente frustrantes. Mas isso expressa as contradições da Espanha, uma sociedade que viveu um longo período de nacional-catolicismo (TERRÓN, 2006) e sobre a qual ainda hoje a lgreja Católica e os setores conservadores têm muita força.

Em uma interpretação liberal do princípio da "liberdade de ensino", consagrada no artigo 27.1 da Constituição, a LODE define em seu artigo 21.1:

\footnotetext{
66 Na realidade existe uma triple red porque há a rede pública, majoritária; a rede privada, minoritária e
} extremamente elitista; e a rede privada concertada, cuja definição está na próxima nota. 
Toda persona física o jurídica de carácter privado y de nacionalidad española tiene libertad para la creación y dirección de centros docentes privados, dentro del respeto a la Constitución y lo establecido en la presente ley. (ESPAÑA, 1985, p. 21018).

Como compatibilizar essa leitura liberal do artigo 27.1 com o direito à Educação, que consta no mesmo artigo? "Todos tienen el derecho a la educación. Se reconoce la libertad de enseñanza." (ESPAÑA, 1996, p. 8). Como contemplar também o que está enunciado no artigo 27.4 "La enseñanza básica es obligatoria y gratuita"? A saída (liberal, diga-se) foi legitimar legalmente a subvenção estatal às escolas privadas, situação que já vinha desde a $L G E$, mas não tinha a devida regulamentação e o devido controle social, como reconhece a própria $L O D E$ em seu preâmbulo. Com isso surgiram os centros concertados ${ }^{67}$ : escolas privadas, mas mantidas com dinheiro público e, portanto, sujeitas a um certo controle da comunidade e obrigadas a oferecer um ensino gratuito a seus alunos. O Título IV De los centros Concertados - da LODE regulamenta o funcionamento das escolas concertadas. $\mathrm{O}$ item 1 do artigo 51 deixa claro o papel desse tipo de centro escolar no sistema de ensino espanhol:

El régimen de conciertos que se establece en el presente Título implica, por parte de los titulares de los centros, la obligación de impartir gratuitamente las enseñanzas objeto de los mismos. (ESPAÑA, 1985, p. 21020).

Enfim, como foi discutido anteriormente, a Educação é um subsistema da cultura (GIMENO SACRISTÁN, 2006) e da sociedade, portanto, expressa seus conflitos e contradições, suas disputas ideológicas. É normal que assim o seja se definirmos ideologia, conforme foi feito no capítulo 2 da parte I, como busca de atribuição de sentido a formas simbólicas na criação e sustentação de relações de dominação no interior de uma determinada sociedade (THOMPSON, 2000). Porém, não é fácil desvendar certas posições ideológicas porque, muitas vezes, elas estão camufladas sob o ideológico discurso da "neutralidade ideológica".

Veja o que diz o artigo 18.1 do capítulo II da $L O D E$, que regulamenta o funcionamento das escolas públicas na Espanha:

67 "Centro educativo privado sostenido con fondos públicos sobre la base de un concierto con la administración educativa competente, que supone el cumplimiento de una serie de condiciones. Este tipo de centros está regulado por la Ley Orgánica Reguladora del Derecho a la Educación (LODE) de 1985." (COMISIÓN EUROPEA, 2008). 
Todos los centros públicos desarrollarán sus actividades con sujeción a los principios constitucionales, garantía de neutralidad ideológica y respeto de las opciones religiosas y morales a que hace referencia el artículo 27.3 de la Constitución ${ }^{68}$. (ESPAÑA, 1985, p. 21017).

Entretanto, no capítulo III, que regulamenta o funcionamento dos centros privados, não há uma só palavra sobre a necessidade de observância da mesma neutralidad. Isso não é ideológico? Claro, como é que se pode exigir neutralidade ideológica das escolas privadas que são em sua maioria pertencentes a ordens religiosas? Aliás, o artigo 27.3 da Constituição e o artigo 18.1 da LODE existem devido à força político-ideológica da Igreja Católica e o mencionado artigo da $L O D E$ deve existir para que tal ideologia não seja questionada. Pelos termos do artigo 18.1, pode-se depreender que ideológicos devem ser apenas os defensores da uma escola verdadeiramente pública e laica.

A Constituição Espanhola, em seu artigo 16.1, garante a "liberdade ideológica" - Se garantiza la liberdad ideológica, religiosa y de culto de los individuos y las comunidades sin más limitación [...]" - o que é bem diferente da neutralidad ideológica que o artigo 18.1 da $L O D E$ exige, e pior, apenas das escolas públicas.

Entretanto, é preciso reconhecer que a $L O D E$ permitiu uma democratização da gestão e do controle dos centros de ensino, inclusive dos privados concertados. Essa lei definiu a criação de um "Conselho Escolar" em cada centro público e privado concertado, composto por representantes de todos os setores da comunidade escolar. De acordo com seu artigo 56:

El Consejo Escolar de los centro concertados estara constituido por:

- El director;

- Tres representantes del titular del centro;

- Cuatro representantes de los profesores;

- Cuatro representantes de los padres o tutores de los alumnos;

- Dos representantes de los alumnos, a partir del ciclo superior de la educação general básica ${ }^{69}$;

68 "Los poderes públicos garantizan el derecho que asiste a los padres para que sus hijos reciban la formación religiosa y moral que esté de acuerdo con sus propias convicciones." (ESPAÑA, 1996, p. 8).

69 Com a mudança estrutural imposta pela LOGSE (ESPAÑA, 1990) os dois representantes dos alunos passaram a ser eleitos entre seus pares a partir do primeiro curso da educación secundaria obligatoria. A LOE (ESPAÑA, 2006a) buscando aumentar o controle do Estado sobre as escolas concertadas introduziu no "Conselho Escolar" um representante do município em que se encontra a escola. 
- Un representante del personal de administración y servicios. (ESPAÑA, 1985, p. 21021).

Por isso, apesar da concessão do governo socialista com a criação do regime de conciertos, possibilitando a permanência de uma rede privada subvencionada paralelamente à pública, os representantes das escolas particulares, majoritariamente católicas, não ficaram plenamente satisfeitos com a $L O D E$. Como afirma Rozada (2002, p. 24):

Es cierto que las resistencias a esta ley por parte de los sectores sociales más conservadores, ligados a la Iglesia Católica, fueron muchas, aunque quizás el gobierno de entonces fue más tímido de lo que le correspondía, si se tienen en cuenta los millones de votos que le habían llevado al poder.

Apesar das contradições apontadas, a LODE contribuiu para o processo de democratização da escolarização e de gestão das escolas. Assim, mesmo Rozada (2002, p. 24), depois de criticar duramente o regime de conciertos, concede: "De todos modos me parece bastante evidente que la LODE marcó sin duda el techo más alto en la democratización del sistema de enseñanza en la historia reciente de nuestro país.".

O período que vai até a $L O D E$ foi marcado pela experimentação. Especialmente depois da chegada dos socialistas ao poder, o governo passou a investir numa reforma de caráter experimental. Ou seja, esperava-se que as experiências mais bem sucedidas pudessem ser generalizadas para todo o sistema educativo. Foi uma época de proximidade com os MRP que receberam estímulo e apoio governamental. Dentro e fora do governo muitos acreditavam ser possível uma reforma alternativa ao tecnicismo que imperou na $L G E$. Entretanto, com o isolamento dos MRP e a falta de apoio da maioria dos professores, começa a aumentar, dentro e fora do governo, a pressão para que fosse feita uma reforma nos moldes tradicionais. A inviabilização da reforma experimental vai acabar desembocando na elaboração da Ley de Ordenación General del Sistema Educativo (LOGSE). 


\section{Ley de Ordenación General del Sistema Educativo (LOGSE)}

Em 3 de outubro de 1990 foi aprovada na Câmara dos Deputados a Ley Orgânica 1/1990 de Ordenación General del Sistema Educativo (LOGSE) que revoga e substitui a LGE. Essa lei foi elaborada durante o mandato do primeiroministro Felipe González Márquez (1982-1996), do Partido Socialista Obrero Español (PSOE). Sua aprovação deu-se quando o Ministerio de Educación y Ciencia era ocupado por Javier Solana (1988-1992), mas foi gestada sob o comando do ministro José Maria Maravall (1982-1988).

A LOGSE, uma reforma de caráter global, procurou implantar mudanças profundas e abrangentes no sistema educativo espanhol, como veremos a seguir, buscando dar respostas às transformações políticas, econômicas, culturais e tecnológicas pelas quais o país vinha passando desde a $L G E$, como indica o trecho a seguir.

Todos os aspectos do sistema educativo, que até então eram regulados pela $L G E$, sofrem modificações com a LOGSE. No próprio preâmbulo, depois de afirmar que apesar da aplicação dos mecanismos políticos e jurídicos próprios da transição, que permitiram superar os resíduos autoritários herdados da reforma de 1970 - há referência explícita à $L O D E$, que garantiu direitos e liberdades relacionadas à Educação - destaca que faltava uma reforma que ordenasse todo o sistema, adaptando-o às novas demandas da sociedade:

No se había abordado, sin embargo, la reforma global que ordenase el conjunto del sistema, que lo adaptase en su estructura e funcionamiento a las grandes transformaciones producidas en estos últimos veinte años. En este período de nuestra historia reciente se han acelerado los cambios en nuestro entorno cultural, tecnológico e productivo, y la sociedad española, organizada democráticamente en la Constitución de 1978, ha alcanzado su plena integración en las Comunidades Europeas. (ESPAÑA, 1990, p. 28927).

Nesses vintes anos que transcorreram desde a votação da $L G E$, a sociedade espanhola viveu profundas transformações: políticas, econômicas, sociais, culturas, tecnológicas. Algumas respostas a essas mudanças, como foi 
mencionado, já foram dadas em leis anteriores, como a Ley Orgánica Reguladora del Derecho a la Educación (LODE), que como o próprio nome sugere assegurou legalmente o direito à Educação a todos os espanhóis e a liberdade de ensino. Enfim, regulamentou os direitos assegurados pelo artigo 27 da Constituição de 1978. Como foi visto, a principal transformação pela qual a Espanha passou naqueles vinte anos foi o fim da ditadura e a legitimação da democracia com a nova Constituição. Portanto, tratava-se de se adaptar a uma importantíssima e crucial transformação política.

O trecho acima faz também referência à integração às Comunidades Européias, outro marco transformador importante da Espanha recente. A entrada do país na União Européia em 1986 impôs uma série de mudanças ao país, inclusive no campo educacional, já que seu sistema educativo passou a ser cobrado para que houvesse uma equiparação ao dos outros membros da Comunidade em termos de taxa de escolarização, desempenho dos alunos etc.

Menciona também a necessidade de se adaptar às mudanças tecnológicas e produtivas. De fato, a lei foi elaborada para dar respostas às novas demandas econômicas impostas pela terceira revolução industrial ou revolução técnico-científica - especialmente a extensão da escolaridade e a melhor qualificação da mão-de-obra. Enfim, dava respostas às demandas criadas pela entrada do capitalismo em sua etapa informacional-global (CASTELLS, 2000), caracterizada pelo regime de acumulação flexível (HARVEY, 1993). A LGE, de 1970, por sua vez, como vimos, ainda dava respostas às demandas da segunda revolução industrial, do regime de acumulação fordista.

Coroando o esgotamento da fase de experimentação, que buscava uma alternativa à perspectiva técnica, a LOGSE materializa a vitória do tecnicismo e a retomada do modelo de ensino tecnocrático de massas implantado a partir da $L G E$ (ROZADA, 2002; TERRÓN, 2006), embora com cores democráticas. Os MRP não tinham apoio da maioria dos professores e crescia dentro e fora do sistema de ensino a cobrança por uma reforma ordenada e eficaz. A administração do governo central não tinha nenhum projeto de reforma em mãos, enquanto era elaborado por César Coll na Catalunha o projeto Marc Curricular per a l'Ensenyament Obligatori 
(1986). Em 1985, Coll, psicólogo e professor da Universidade de Barcelona, foi contratado pelo Departamento de Ensino do governo da Catalunha para fazer o desenho curricular para o sistema de ensino básico dessa Comunidade Autônoma. Segundo Rozada (2002, p. 29):

Este trabajo tuvo una importancia capital porque le ofreció en bandeja a la Administración del momento la posibilidad de salir del atolladero. Una administración que para entonces ya había acumulado suficiente desconfianza hacia los sectores progresistas de las pedagogías académica y alternativa. El trabajo de Coll era en sí mismo un ejemplo del orden y del rigor que parecía prometer aportarle a quien lo adoptara.

Este trabalho de Coll com pequenas mudanças foi publicado em espanhol em 1987 com o título Psicología y Curriculum e serviu de base para a elaboração da LOGSE. Trata-se de um trabalho que se orienta claramente pelo interesse técnico, a começar pelos termos e metáforas utilizados: "objetivos", "guias", "desenho curricular". Veja como Coll (1991, p. 31-2) define currículo:

Resumiendo, entendemos el curriculum como el proyecto que preside las actividades educativas escolares, precisa sus intenciones y proporciona guías de acción adecuadas y útiles para los profesores que tienen la responsabilidad directa de su ejecución. Para ello el currículo proporciona informaciones concretas sobre qué enseñar, cuándo enseñar, cómo enseñar y qué, cómo y cuándo evaluar.

Antes de completar sua definição, lembra os significados do conceito de instrução, que em sentido amplo é utilizado como sinônimo de "educação formal" e de "escolarização", e em sentido restrito, refere-se aos componentes de metodologia de ensino. Acrescenta que o conceito de currículo é muitas vezes utilizado em um sentido bem mais limitado do que ele definiu anteriormente, referindo-se unicamente aos objetivos e aos conteúdos da educação formal. Então, completa sua definição: "Nuestra manera de entender el Diseño Curricular incluye pues tanto aspectos curriculares en sentido limitado (objetivos y contenidos) como aspectos instruccionales (relativos al cómo enseñar)." (COLL, 1991, p. 33). Como já alertou Grundy (1994, p. 49): "Hablar sobre el 'diseño curricular' suele indicar un interés técnico.". Um currículo organizado em torno de objetivos também é claramente uma indicação de sua orientação técnica. 
A LOGSE foi uma reforma global, abrangente e promoveu avanços estruturais importantes, como a extensão da escolaridade obrigatória e gratuita até os 16 anos, a expansão do "tronco comum" com o estabelecimento - pela primeira vez na história escolar espanhola - de uma educação secundária obrigatória e comprensiva $^{70}$ (ver quadro 6, no qual é possível a comparação com o sistema educativo da $L G E$ ). Porém, em sua modalidade curricular foi claramente orientada pelo interesse técnico.

A LOGSE não chega a mencionar a necessidade de adaptação à sociedade do conhecimento, mas fala da importância de dar resposta adequada às exigências sociais do presente e do futuro. A que está por vir é chamada de "sociedade do saber".

En esta sociedad del futuro, configurada progresivamente como una sociedad del saber, la educación compartirá con otras instancias sociales la transmisión de información y conocimientos, pero adquirirá aún mayor relevancia su capacidad para ordenarlos críticamente [...] (ESPAÑA, 1990, p. 28928, grifo nosso).

Quando essa lei foi elaborada ainda não havia se disseminado o conceito de sociedade do conhecimento, que, por sua vez, aparece no preâmbulo da Ley Orgánica de Educación (LOE), como justificativa para essa mais recente reforma. A necessidade de adaptação do sistema de ensino às transformações da chamada "sociedade do saber", que então estava por vir, fica evidente no trecho acima e no que vem a seguir.

Todas estas transformaciones constituyen de por si razones más profundas a favor de la reforma del sistema educativo, para que este sea capaz de adaptarse a las que ya se han producido, sino de prepararse para las que se avecinan, contando con una mejor estructura, con mejores instrumentos cualitativos y con una concepción más participativa y de adaptación al entorno. (ESPAÑA, 1990, p. 28927, grifo nosso).

Esse pequeno trecho deixa claro que toda reforma (e não apenas a LOGSE) é pensada e executada para adaptar o sistema educativo às demandas da sociedade no momento histórico em que foi gestada. De fato, o verbo "adaptar" e o substantivo "adaptação" aparecem de forma recorrente no preâmbulo da LOGSE: o primeiro, seis vezes; o segundo, quatro.

\footnotetext{
70 A discussão sobre o significado deste termo vem logo a seguir.
} 
Mas a LOGSE, como consta também do preâmbulo, pretendia ainda resolver problemas estruturais e especificamente educativos, erros de concepção, insuficiências e disfunções que foram se acumulando ao longo do tempo.

Uma das mudanças estruturais mais importantes que consta da LOGSE, em consonância com o artigo 27.4 da Constituição ${ }^{71}$, foi a extensão da escolaridade básica, gratuita e obrigatória, até os 16 anos, ampliando para 10 anos a permanência mínima na escola. A importância dessa mudança é destacada no preâmbulo da lei:

La Ley de Ordenación General del Sistema Educativo da forma jurídica a la propuesta y se convierte en el instrumento esencial de la reforma. Con la consecución de objetivo tan fundamentales como la ampliación de la educación básica, llevándola hasta los dieciséis años, edad mínima legal de incorporación al trabajo, en condiciones de obligatoriedad y gratuidad; [...] (ESPAÑA, 1990, p. 28928).

Essa medida resolve uma defasagem que existia no sistema anterior, herdado da $L G E$, no qual os estudantes terminavam a Educación General Básica $(E G B)$, em média, com 14 anos, dois anos antes da idade mínima para a incorporação ao mercado de trabalho. Se bem que a educação obrigatória e gratuita, na realidade, já se estendia até os 16 anos para quem não fosse para o bachillerato. Isso já tinha sido contemplado pela LGE na Formación Profesional 1 (FP1). A diferença é que com a LOGSE a escola básica ampliou-se e, além de obrigatória e gratuita, tornou-se mais comprensiva. Digo "mais" porque é preciso reconhecer que a $L G E$ de 1970 foi a responsável por dar o primeiro impulso para a implantação de um sistema comprensivo ao criar a $E G B$ e estender o ensino básico e gratuito até os 14 anos. Embora os oito anos da EGB não possam ser considerados plenamente comprensivos já que havia uma diferenciação no $7^{\circ}$ e $8^{\circ}$ anos.

$\overline{71}$ “La enseñanza básica es obligatoria y gratuita.” (ESPAÑA, 1996, p. 4). 
$\mathrm{Na}$ Europa, antes da existência da escola comprensiva ${ }^{72}$, que começa a ser implantada após a Segunda Guerra Mundial, existiam duas redes ou dois troncos de ensino separados. Isso não era apenas um fenômeno espanhol, embora lá a escola comprensiva tenha sido implanta mais tarde. Os franceses, por exemplo, em busca de síntese chamavam essas duas redes de "P-P" e "S-S", ou seja, as iniciais de "Primária-Profissional" e "Secundária-Superior" (ESCUDERO, 1997). O primeiro tronco estava voltado para a educação funcional das massas e o segundo, para a educação propedêutica das elites. A maioria dos países europeus adotou o sistema de ensino comprensivo, mas há alguns que ainda seguem com uma diferenciação precoce. Nas palavras de Álvaro Marchesi, um dos pais da LOGSE, e compreensivelmente um defensor do ensino comprensivo:

La enseñanza comprensiva es una forma de organización escolar en la que se proporciona a todos los alumnos las mismas experiencias básicas de aprendizaje y en la que se combinan los componentes académicos de la formación con los técnicosprofesionales. Supone retrasar la separación de los alumnos en ramas educativas diferentes. Es una modelo presente, con variaciones, en los Estados Unidos, en los países escandinavos, en Gran Bretaña, en Bélgica y en el sur de Europa. El sistema contrario se basa en la diferenciación de los alumnos en opciones educativas alternativas a partir de la educación primaria, normalmente en dos vías: la académica y la profesional. Los países más representativos de este modelo organizativo son Alemania, Holanda, Suiza y Austria. (MARCHESI, 2005, p. 49).

Juan Manuel Escudero, professor da Universidade de Murcia, também dá sua definição para o conceito de comprensividad e defende que se trata de um princípio essencialmente democrático:

72 Escuela comprensiva (usa-se também enseñanza comprensiva) vem do inglês comprehensive school, tanto que alguns autores como Rozada (2002), Terrón (2006) e Viñao (2006) grafam comprehensiva. As comprehensive school começaram a ser implantadas na Inglaterra na década de 1950 e se generalizaram a partir dos anos 1960 unificando as escolas secundárias (grammar school), voltadas para a classe média, e as escolas secundárias modernas, direcionadas para a classe operária (Goodson, 1995). O adjetivo compresivo em espanhol, no sentido aqui empregado, indica que se trata de uma escola básica que "contém ou inclui" a todos os alunos, independente de classe social, gênero ou etnia, dos seis aos dezesseis anos (em média), sem nenhum tipo de diferenciação. Algum tipo de diferenciação, ou itinerário, como eles dizem, só vai ocorrer no secundário pós-obrigatório. Em português, apesar do verbo "compreender" ter também a conotação de "incluir", o adjetivo "compreensivo" é mais utilizado entre nós para se referir a uma pessoa de boa vontade, que admite um ponto de vista alheio. Já a palavra "inclusiva” também não é adequada porque entre nós é utilizada para definir uma escola que atende alunos com necessidades especiais. Assim, o correspondente em português a comprehensive school, do inglês, e a escuela comprensiva, do espanhol, seria "escola integrada". Manterei o termo comprensivo para me referir ao sistema de ensino espanhol criado pela LOGSE e vigente até hoje. 
El curriculum de la escuela comprensiva está basado en el principio esencialmente democrático de que todos los miembros de la sociedad pueden y deben participar en los procesos de toma de decisiones, lo que da lugar a posiciones educativas que prescriben un curriculum general e inclusivo para los alumnos de todo tipo de origen social. (ESCUDERO, 1997, p. 27).

Evidentemente, nem todos vêem a comprensividad como uma medida positiva, como um avanço, como é o caso de Pascual Tamburri, um dos mais ferozes críticos da LOGSE e de seus pressupostos igualitaristas.

La LOGSE partía de la idea de que la obligatoriedad de la enseñanza hasta los dieciséis anos (algo evidentemente bueno) equivalía a la comprensividad (que todos los alumnos debían estudiar los mismo contenidos en las mismas aulas hasta esa edad: algo evidentemente imposible $y$, de ser posible, malo). (TAMBURRI, 2007, p. 20).

Embora a comprensividad não fosse consensual, para garanti-la a reforma da LOGSE reestruturou todo o sistema educativo, criou a educação primária de seis anos e a Educación Secundaria Obligatoria (ESO), de quatro anos. A ESO incorporou $07^{\circ}$ e o $8^{\circ}$ anos da antiga $E G B$ e $01^{\circ}$ e o $2^{\circ}$ anos do antigo $B U P$ (ver o quadro 6). Rompendo com os itinerários que existiam no $7^{\circ}$ e $8^{\circ}$ anos da $E G B$, essa nova estrutura do ensino básico deveria ser comprensiva. Entretanto, a lei abria a possibilidade de uma gradativa diferenciação no final da ESO para dar conta da diversidade dos alunos.

Este período formativo común a todos los españoles se organizará de manera comprensiva, compatible con una progresiva diversificación. En la enseñanza secundaria obligatoria, tal diversificación será creciente, lo que permitirá acoger mejor los intereses diferenciados de los alumnos, adaptándose al mismo tiempo a la pluralidad de sus necesidades y aptitudes, con el fin de posibilitarles que alcancen los objetivos comunes de esta etapa. (ESPAÑA, 1990, p. 28929, grifo nosso).

Mas essa diversificação se daria no mesmo "tronco comum", por meio de disciplinas optativas. Na educação secundária pós-obrigatória, por outro lado, são estabelecidos claramente dois itinerários separados: a formação profissional de nível médio (dois anos), preparando os estudantes para a entrada no mercado de trabalho após a obtenção do diploma de técnico, e o bachillerato $^{73}$ (dois anos), de caráter

\footnotetext{
73 Utilizarei o termo bachillerato, em vez de bacharelado, e bachiller, em vez bacharel, como aparece em algumas traduções para o português, porque no Brasil esses termos têm outro significado. Aqui, bacharelado define uma das modalidades de formação superior - a outra é a licenciatura. No Brasil adquire o título de bacharel quem se forma em algum curso superior, habilitando-o a trabalhar na área - o título de licenciado
} 
propedêutico, permitindo que, após a obtenção do título de bachiller, o estudante esteja apto a concorrer às provas de acesso à universidade ou aceder aos cursos de formação profissional específica de grau superior. O quadro 5 mostra o sistema educativo criado pela LOGSE e o quadro 6, sua comparação com o sistema da $L G E$. Observando-os lado-a-lado fica mais evidente a principal conquista da LOGSE: a extensão da educação comprensiva, obrigatória e gratuita até os 16 anos de idade.

\section{Quadro 5. Sistema Educativo LOGSE ${ }^{74}$}

habilita seu possuidor a lecionar no ensino básico. Na Espanha, o bachillerato é parte do ensino secundário, tem um caráter preparatório para o ensino superior. Naquele país, obtém o título de bachiller quem conclui o ensino secundário pós-obrigatório, habilitando-o a prestar as Pruebas de acceso a la Universidad ou aceder aos cursos profissionalizantes de grau superior.

74 O sistema de ensino espanhol ordenado pela LOGSE era dividido em regime geral (régimen general) e regime especial (régimen especial). O quadro mostra os dois, mas o objeto de interesse deste trabalho é apenas o sistema de ensino do regime geral. 


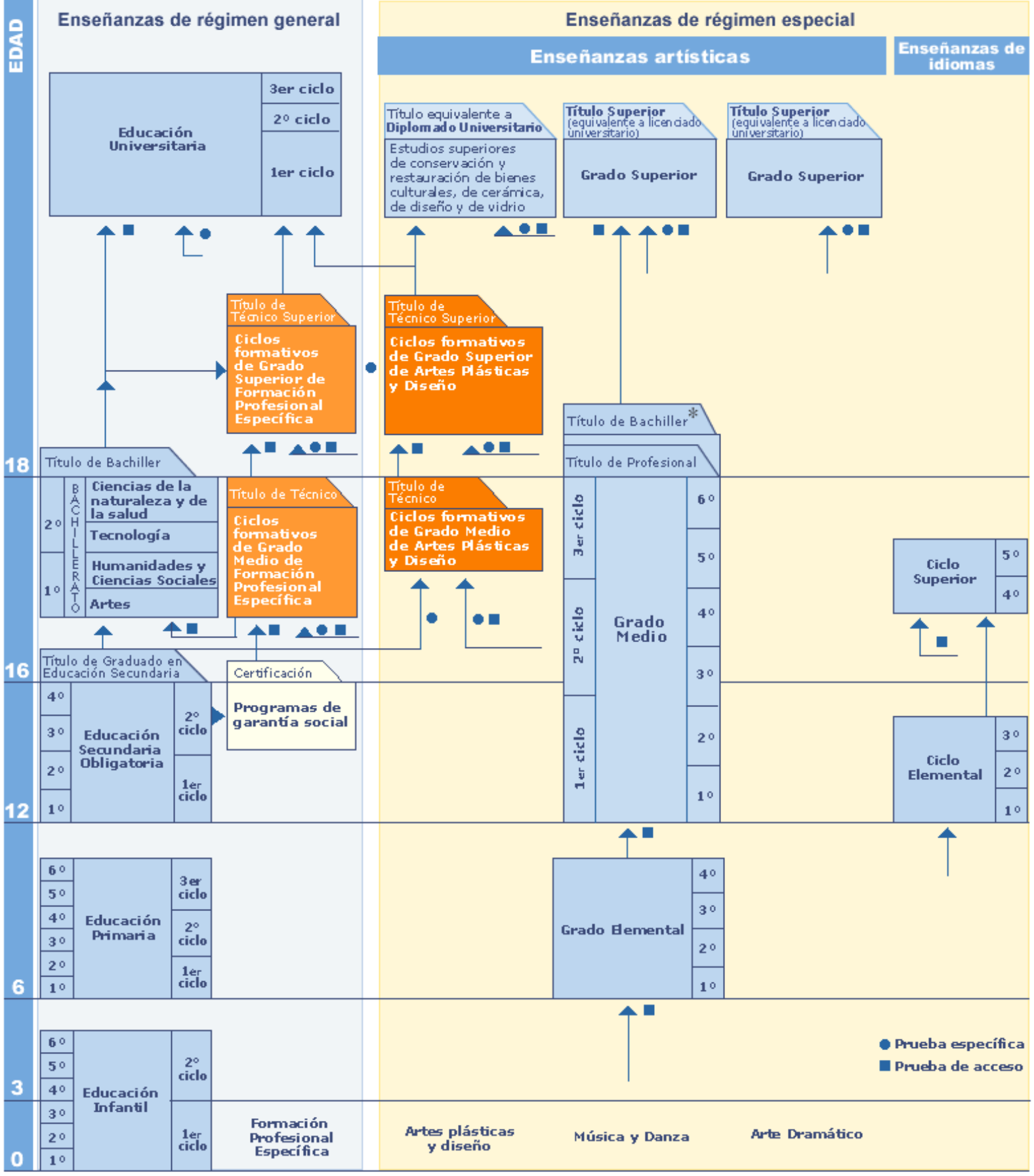

* Con materias comunes de Bachillerato

Fonte: Ministerio de Educación y Ciencia. Sistema Educativo. Disponível em: <www.mec.es/educa/sistemaeducativo/logse/siseduc.html>. Acesso em: 8 fev. 2008. 


\begin{tabular}{|c|c|c|}
\hline \multicolumn{3}{|c|}{$\begin{array}{l}\text { Quadro 6. Espanha: sistema educativo obrigatório e pós- } \\
\text { obrigatório }\end{array}$} \\
\hline Idade $^{\star}$ & Sistema LGE (1970) & Sistema LOGSE (1990) \\
\hline $6-7$ & 1ํ Educación General Básica (EGB) & 1ํEducación Primaria \\
\hline $7-8$ & $2^{\circ} \mathrm{EGB}$ & $2^{\circ}$ Primaria \\
\hline $8-9$ & 3 EGB & 3ํㅗㄱimaria \\
\hline $9-10$ & 4 EGB & 4을 Primaria \\
\hline $10-11$ & 5 EGB & 5 Primaria \\
\hline $11-12$ & $60 \mathrm{EGB}$ & 60 Primaria \\
\hline $12-13$ & $7^{\circ} \mathrm{EGB}$ & 1ํㅡd. Secundária Obligatória (ESO) \\
\hline $13-14$ & $8^{\circ}$ EGB (título: graduado escolar) & $2^{\circ} \mathrm{ESO}$ \\
\hline \multirow[t]{2}{*}{$14-15$} & $1 \%$ BUP ${ }^{\star *}$ & \multirow[t]{2}{*}{$3^{\circ} \mathrm{ESO}$} \\
\hline & 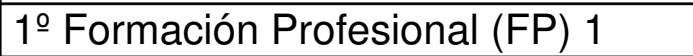 & \\
\hline \multirow[t]{2}{*}{$15-16$} & $2^{\circ} \mathrm{BUP}$ & \multirow{2}{*}{$\begin{array}{l}\text { 4 ESO (título: graduado en } \\
\text { educación secundaria) }\end{array}$} \\
\hline & 2º FP 1 (título: técnico auxiliar) & \\
\hline \multirow[t]{2}{*}{$16-17$} & 3으 BUP (título: bachiller) & 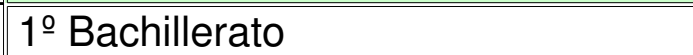 \\
\hline & $30 \mathrm{FP} 2$ & 1ㅇ FP específica de grado medio \\
\hline \multirow[t]{3}{*}{$17-18$} & $\mathrm{COU}^{\star \star \star *}$ & $2^{\circ}$ Bachillerato (título: bachiller) \\
\hline & 4ํFP 2 (título: técn. especialista) & 2 FP (título: técnico) \\
\hline & $\square$ Educación obligatoria y gratuita & $\square$ Educación obligatoria y gratuita \\
\hline
\end{tabular}

Fonte: Ministerio de Educación y Ciencia. Sistema Educativo. Disponível em: <www.mec.es/educa/sistemaeducativo/logse/siseduc.html>. Acesso em: 4 jun. 2006.

*Trata-se de uma média de idade teórica porque há defasagens; **Bachillerato Unificado Polivalente; ***Curso de Orientación Universitária.

A questão da comprensividad é um dos aspectos centrais das reformas do ensino secundário e ao mesmo tempo um dos que levanta mais enfrentamentos ideológicos. Talvez porque como afirma Escudero (1997, p. 26): "La educación secundaria es el corazón de cualquier sistema educativo. Desde hace décadas, los grandes debates de fondo en educación han venido centrándose en la compleja - y controvertida - naturaleza de este tramo del sistema.".

$\mathrm{Na}$ Espanha, com a crescente demanda pela educação secundária e com a implantação de um ensino comprensivo, as escolas ficaram mais diversas. Com isso surge uma importante questão: como compatibilizar o princípio da comprensividad, que se assenta nos ideais de igualdade, solidariedade e integração social, com o respeito à diversidade, assentada em valores como pluralismo, valorização da diferença e desenvolvimento individual? Em tempos neoliberais, de 
enfraquecimento dos projetos coletivos e de esgotamento geral dos impulsos utópicos, como diz Habermas (2005), esses valores têm se sobreposto àqueles. É fácil perceber que é por essa brecha que a escola comprensiva mais sofre ataques, inclusive com indisfarçável manipulação ideológica de teor conservador. Porém, a questão de fundo não tem um caráter maniqueísta como muitos apresentam, não é comprensividad ou diversidade, mas sim comprensividad e diversidade. A problema é como compatibilizar esses dois princípios, porque na realidade quanto mais inclusiva for a escola, mais diversa ela será.

Para Fernández Enguita (2003), as três grandes dimensões das sociedades que mais diretamente afetam a educação escolar são a classe social, o gênero e a etnia. Em seus primórdios, os sistemas de ensino excluíam, ou pouco incluíam, os trabalhadores, as mulheres e as etnias minoritárias. Eram voltados para a preparação de setores da elite - pequena e média burguesia, masculina e da etnia dominante - para assumir funções eclesiásticas, burocráticas e militares. A alta elite, a aristocracia, continuava estudando com preceptores. No caso da Espanha, a elite dominante era branca e católica, do outro lado, a principal minoria excluída era composta pelos ciganos. Com o passar do tempo os trabalhadores começaram a ser incorporados ao sistema escolar, mas num tronco terminal, o "P-P", conforme síntese dos franceses apontada por Escudero (1997). As mulheres foram incorporadas gradativamente, mas durante muito tempo em classes separadas e com uma formação voltada mais para as primeiras letras, a doutrinação cristã e a formação própria ao gênero: trabalhos próprios do sexo feminino e noções elementares de higiene doméstica, como propunha 0 artigo $5^{\circ}$ da Ley Moyano de 1857. A integração de minorias étnicas foi ainda mais tardia.

A reforma de caráter comprensivo, como vimos, incorporou sobretudo os trabalhadores em um mesmo tronco escolar, ligando o "P-P" ao "S-S". Porém, acabou ampliando também a diversidade ao incorporar as mulheres e as etnias minoritárias, que, em grande parte, também estão no mercado de trabalho. Fernández Enguita (2003) reserva o termo comprensividad para classe social, mais precisamente para a reforma educacional que incorpora os trabalhadores à escola. Para a incorporação de gênero, ou seja, das mulheres, reserva o termo 
“coeducação", e para a incorporação de etnias minoritárias, "integração”. Buscando apreender a realidade espanhola, ele organizaou um esquema (ver quadro 7) que sintetiza as desigualdades relativas a classe, gênero e etnia, assim como as políticas públicas para compensá-las e seus resultados.

\begin{tabular}{|c|c|c|c|}
\hline \multicolumn{4}{|c|}{ Quadro 7. Clase, género y etnia ante la educación } \\
\hline & clase & género & etnia \\
\hline $\begin{array}{l}\text { Origen } \\
\text { exclusión / } \\
\text { seareaación }\end{array}$ & $\begin{array}{l}\text { exclusión / escuela } \\
\text { popular }\end{array}$ & $\begin{array}{l}\text { exclusión / escuelas } \\
\text { separadas por sexos }\end{array}$ & $\begin{array}{l}\text { exclusión / escuelas } \\
\text { puente }\end{array}$ \\
\hline Reforma & Comprehensividad & Coeducación & Integración \\
\hline Incorporación a & $\begin{array}{l}\text { Escuela de clase } \\
\text { media, urbana }\end{array}$ & Escuela masculina & $\begin{array}{l}\text { Escuela nacional, } \\
\text { paya* etc. }\end{array}$ \\
\hline Resultado & $\begin{array}{l}\text { Desigual y } \\
\text { mediocre }\end{array}$ & $\begin{array}{l}\text { Homogéneo y } \\
\text { brillante }\end{array}$ & $\begin{array}{l}\text { Casuístico y } \\
\text { desastroso } \\
\end{array}$ \\
\hline $\begin{array}{l}\text { Desigualdades } \\
\text { económicas }\end{array}$ & $\begin{array}{l}\text { Relevantes } \\
\text { Distintas } \\
\text { prioridades } \\
\text { familiaroc }\end{array}$ & $\begin{array}{l}\text { Inexistentes } \\
\text { Posible } \\
\text { discriminación }\end{array}$ & $\begin{array}{l}\text { Bolsas de pobreza } \\
\text { Posible } \\
\text { disfuncionalidad }\end{array}$ \\
\hline $\begin{array}{l}\text { Cultura de los } \\
\text { distintos } \\
\text { públicos }\end{array}$ & $\begin{array}{l}\text { Subculturas, } \\
\text { variantes de una } \\
\text { cultura }\end{array}$ & $\begin{array}{l}\text { Roles diferentes } \\
\text { dentro de una } \\
\text { cultura única } \\
\end{array}$ & $\begin{array}{l}\text { Culturas distintas, } \\
\text { tal vez } \\
\text { contrapuestas }\end{array}$ \\
\hline $\begin{array}{l}\text { Identificación } \\
\text { instrumental, con la } \\
\text { escuela, por parte } \\
\text { del grupo en } \\
\text { desventaja }\end{array}$ & $\begin{array}{l}\text { Baja o alta según } \\
\text { creencia en } \\
\text { movilidad, con } \\
\text { cierta } \\
\text { independencia de la } \\
\text { clase. }\end{array}$ & $\begin{array}{l}\text { Alta en todo caso, } \\
\text { como mejor } \\
\text { mecanismo de } \\
\text { acceso a mercado } \\
\text { de trabajo }\end{array}$ & $\begin{array}{l}\text { Alta en algunos } \\
\text { inmigrantes, baja } \\
\text { en grupos } \\
\text { fuertemente } \\
\text { marginados } \\
\text { (nearos_aitanos) }\end{array}$ \\
\hline $\begin{array}{l}\text { Identificación } \\
\text { expresiva con la } \\
\text { cultura escolar }\end{array}$ & $\begin{array}{l}\text { Baja para clase } \\
\text { obrera, alta para } \\
\text { clase media }\end{array}$ & $\begin{array}{l}\text { Alta en todo caso, } \\
\text { más favorable que } \\
\text { familia o trabajo }\end{array}$ & $\begin{array}{l}\text { Según distancia } \\
\text { cultural, relaciones } \\
\text { grupales, cierre... }\end{array}$ \\
\hline
\end{tabular}

Fonte: Fernández Enguita (2003, p. 22).

*Payo é a forma como os ciganos se referem aos que não pertencem à sua etnia, portanto, escuela paya é a escola voltada aos que não são ciganos.

Antes de prosseguir, são necessárias algumas palavras sobre o conceito de diversidade em educação. Não vejo nada a acrescentar à definição dada por Escudero (1997, p. 32):

La diversidad se concibe usualmente, y en ocasiones exclusivamente, como un conjunto formado por las capacidades cognitivas, intereses y motivaciones de un alumno que definen su capacidad de aprendizaje ( $y$, por consiguiente, su rendimiento académico) en un momento concreto y situación educativa en particular. Pero también hay una diversidad derivada de la pertenencia a algún grupo social, étnico, cultural o lingüístico; de hecho, los documentos oficiales de la reforma han hecho referencia a la 
diversidad que se genera por las distintas culturas de procedencia social, la diversidad derivada del sexo, la diversidad en los estilos de aprendizaje, etc.

Em seguida acrescenta que quando a diversidade de origem individual ou social afeta negativamente o rendimento escolar, essa diferença se converte, academicamente falando, em desvantagem e, socialmente, em desigualdade.

O problema é que muitas vezes se tenta vender a desigualdade como se fosse diferença, criando assim uma situação absurda na qual nos encontraríamos, irônica e paradoxalmente, já não somente reproduzindo as desigualdades, mas respeitando-as "democraticamente" como "fato diferencial" entre indivíduos ou grupos. Esse é o risco que está por trás de políticas de atenção à diversidade, como denuncia Escudero (1997), que podem aprofundar a desigualdade.

Parece que é o que pensa, por exemplo, Tamburri (2007, p. 14), um dos maiores críticos da comprensividad:

La atención a la diversidad se va a seguir tratando como si el problema estuviese en los medios materiales, cuando realmente está en la Idea-fuerza de la LOGSE de la igualdad obligatoria entre unos alumnos que siguen siendo, afortunadamente desiguales en capacidades, hábitos, medios y motivaciones.

Representantes dos setores sociais à direita do espectro político, em vez de proporem políticas públicas voltadas para a diminuição das desigualdades subrepticiamente propõem, como denuncia Escudero, tratar a desigualdade como diferença, aprofundando-a ainda mais. Isso é próprio de propostas oriundas do campo ideológico conservador, como denunciam Romero Morante e Luis Gómez (2008, p. 16):

[...] cabe dudar de la potencialidad de la escuela como laboratório de vida democrática cuando el cuestionamento de la comprehensividad, a través de distintas estrategias según paises, está acentuando la tendencia de los "iguales" a buscarse entre si para escolarizarse separados de los "diferentes".

Em teoria, a diversidade deve-se respeitar e até mesmo incentivar, já a desigualdade deve-se combater e tentar compensar. Daí porque um ensino comprensivo necessariamente deve vir acompanhado de mecanismos compensatórios. Entretanto, muitas vezes a diversidade é a origem da desigualdade e, nesse caso, é necessária, respeitando-se a diferença, uma atuação para superar 
a desigualdade. É o caso, por exemplo, de grande parte dos imigrantes que, por sua dificuldade com a língua, seu menor capital cultural, sua condição de pobreza, têm muitos problemas para se integrar às sociedades dos países desenvolvidos, inclusive da Espanha, que cada vez mais vem recebendo estrangeiros. Nesse caso, é necessário compatibilizar o princípio da comprensividad com o princípio da “integração".

Entretanto, o próprio Álvaro Machesi reconhece que se trata de um intento difícil:

Hay que destacar, a partir de estos razonamientos, que la enseñanza comprensiva, junto con una organización mixta y flexible de los grupos de alumnos, es la alternativa más igualitaria pero más difícil. Y existe el riesgo de que tanta dificultad pueda echar por tierra la pretendida igualdad. Este es el dilema en el que se encuentra la educación secundaria en España: si la exigencia de igualdad no está deteriorando la calidad (bajando el nivel en la terminología popular), lo que a su vez podría producir el abandono por parte de un sector de padres de aquellos centros sobre los que recae con mayor fuerza el compromiso de la igualdad: los centros públicos. (MARCHESI, 2005, p. 53).

De fato, isso está acontecendo na Espanha e, como uma profecia autorealizada, a diversidade em grande medida está se convertendo em desigualdade. De acordo com o Ministerio de Educación y Ciencia, no ano escolar 2007/2008, $32,4 \%$ dos alunos da educação não universitária (infantil, primária e secundária) estudavam em escolas privadas e privadas concertadas (ESPAÑA, 2007c, p. 3). No caso da Educação Secundária Obrigatória (ESO), como mostra a tabela 10, esse percentual era ainda maior:

\begin{tabular}{|c|c|c|c|c|c|}
\hline \multirow[t]{2}{*}{ Graus } & \multirow{2}{*}{$\begin{array}{l}\text { alunos } \\
\text { matriculados }\end{array}$} & \multicolumn{2}{|c|}{ pública } & \multicolumn{2}{|c|}{ privada e concertada } \\
\hline & & total & $\%$ & total & $\%$ \\
\hline Secundária & 2.952 .645 & 2.059 .560 & 69,6 & 892.085 & 30,2 \\
\hline ESO & 1.826 .825 & 1.216 .909 & 66,6 & 609.916 & 33,4 \\
\hline Bachillerato & 625.275 & 464.414 & 74,4 & 159.861 & 25,6 \\
\hline Formación Profesional & 500.545 & 378.237 & 75,6 & 122.308 & 24,4 \\
\hline Universitária & 1.381 .749 & 1.239 .429 & 89,7 & 142.320 & 10,3 \\
\hline
\end{tabular}

Fonte: Datos Básicos de la Educación en España en el Curso 2007/2008 (ESPAÑA, 2007c. p. 3). 
Setores sociais de classe média, com maior poder aquisitivo, tendem cada vez mais a colocar seus filhos em escolas privadas ou privadas concertadas, constituindo o que Fernández Enguita (2008) chama de "centros bolha", e na escola pública, os "centro gueto", cada vez mais têm permanecido a população de menor poder aquisitivo que, no caso da Espanha, em grande medida são minorias étnicas, principalmente imigrantes. De acordo com o Ministério da Educação, os imigrantes correspondiam a $8,4 \%$ dos alunos matriculados em toda o sistema educativo não universitário da Espanha no ano letivo 2006/2007: 10,2\% em centros públicos e 4,6\% em centros privados. Na ESO, o índice era de 9,2\%: na escolas públicas o percentual de estrangeiros era de 11,2\%, nas privadas, 5,3\% (ESPAÑA, 2007c).

A alta taxa de estudantes em escolas privadas e privadas concertadas na Espanha não se deve apenas ao fato de ser um país fortemente católico, que por isso dispõe de uma grande rede de escolas confessionais ${ }^{75}$, como muitas vezes se pensa. Como mostra a tabela 11, países igualmente católicos, como a Itália ou Portugal, têm um percentual bem mais baixo de estudantes em escolas privadas e privadas concertadas:

\begin{tabular}{|c|c|c|c|}
\hline \multicolumn{4}{|c|}{$\begin{array}{l}\text { Tabela 11. Distribuição dos alunos de educação primária } \\
\text { e secundária por titularidade/financiamento } \\
\text { (ano letivo 2004-2005) }\end{array}$} \\
\hline Países & $\begin{array}{l}\text { ensino privado } \\
\text { concertado (\%) }\end{array}$ & $\begin{array}{c}\text { ensino } \\
\text { privado }(\%)\end{array}$ & $\begin{array}{c}\text { ensino público } \\
(\%)\end{array}$ \\
\hline Bélgica & 57,0 & - & 43,0 \\
\hline Reino Unido & 37,4 & 4,1 & 58,6 \\
\hline Espanha & 25,3 & 4,6 & 70,2 \\
\hline França & 20,6 & 0,7 & 78,8 \\
\hline Portugal & 4,2 & 8,3 & 87,5 \\
\hline Grécia & - & 6,9 & 93,1 \\
\hline Suécia & 6,8 & - & 93,0 \\
\hline Finlândia & 6,5 & - & 93,5 \\
\hline Itália & 0,2 & 5,4 & 94,4 \\
\hline União Européia & 13,7 & 2,5 & 79,4 \\
\hline
\end{tabular}

Fonte: Datos Básicos de la Educación en España en el Curso 2007/2008 (ESPAÑA, 2007c. p. 15).

75 Segundo Fernández Enguita (2008), com base em dados do Instituto Nacional de Estadística (2003), há 2.654 escolas católicas na Espanha, o que corresponde a 53,2\% da rede de escolas privadas. 
Conforme opinião do sociólogo Mariano Fernández Enguita, expressa no El País, na Espanha os pais procuram as escolas privadas e privadas concertadas (predominantemente confessionais) por três razões: distinção, serviços e disciplina. E acrescenta: "Y si un tercio de la populación quiere mandar a sus hijos a las escuelas privadas, en mi opinión hay otro tercio que los desearía pero, por cuestiones económicas, no puede." (MANETTO, 2007, p. 36). Ou seja, a evasão do ensino público rumo ao privado seria maior ainda se dependesse apenas da vontade dos pais. Em artigo de sua própria lavra, Fernández Enguita (2008) menciona pesquisa na qual se perguntou aos pais dos alunos dos centros públicos se levariam, caso pudessem, seus filhos ao um centro privado: 19\% responderam que sim "com certeza" e 14\%, que sim "provavelmente". "Si estas opciones pudieram realizar-se, el peso de la enseñanza no estatal (privada y concertada) se elevaría al $54 \%$ del total." (FERNÁNDEZ ENGUITA, 2008, p. 8).

Rozada (2002) levanta duas questões que me parecem cruciais nesse debate. 1) A comprensividad tornou a escola mais pública? 2) Ela é compatível com a doble [triple] red existente no sistema de ensino espanhol? Considerando os dados acima diria que não, pois é crescente a diferenciação, a desigualdade entre a escola pública e a privada. Como na Espanha do início do século XX, a escola pública tem ficado cada vez mais para os pobres, que, como vimos, hoje em dia são crescentemente os imigrantes. As escolas concertadas, por sua vez, têm criado variados subterfúgios para selecionar seus alunos, por exemplo, cobrando por transporte escolar e atividades extra-classe, o que contraria o princípio da inclusividade e contribui para o aumento da desigualdade (FERNÁNDEZ ENGUITA, 2008).

Diversos autores dos mais variados matizes ideológicos desconfiam, por razões diferentes, do princípio da comprensividad vigente na educação básica espanhola. Sob uma perspectiva crítica, situando-se no campo da esquerda, José María Rozada, mesmo admitindo que tal princípio é fundamental na escola pública, questiona a forma como foi implantado na Espanha.

La comprehensividad del sistema se podría decir que es una exigencia intrínseca a la escuela pública, de modo que su adopción oficial como modelo podía, 
efectivamente, presentarse como un importante avance en el carácter público de esta última. Así fue entendido y apoyado por muchos, independientemente incluso de lo proclives que fueran hacía la renovación pedagógica. Pero la introducción de la comprehensividad en la educación secundaria se limitó prácticamente de modo exclusivo a la cuestión de la escolaridad. (ROZADA, 2002, p. 32, grifo do autor).

Terrón (2006, p. 148), no mesmo campo teórico-ideológico, ao criticar o enfoque tecnicista da reforma de 1990, apresenta a mesma leitura: "Porque ese enfoque tecnicista de la reforma hará que la comprehensividad quede reducida a una pura cuestión de escolaridad.". Enfim, segundo esses autores, não foram tomadas uma série de medidas necessárias para que houvesse uma verdadeira inclusão, como, por exemplo, maiores investimentos na formação inicial e continuada dos professores e na compensação das desigualdades, garantindo igualdade de oportunidades educativas. Viñao (2006, p. 57), sempre lembrando da necessidade de reformas sociais paralelas às educacionais, alerta para o fato de que a comprensividad se aplica melhor às sociedades igualitárias:

[...] el ideal de una educación comprehensiva tiene más posibilidades de aplicarse o de cumplirse (aunque siga siendo siempre un ideal) en una sociedad con un grado no elevado de desigualdad social que en otra fuertemente desigualitaria.

No entanto, ao afirmar isso, Viñao parece não dar a devida importância ao papel que a própria educação escolar inclusiva pode desempenhar para a diminuição das desigualdades sociais.

Mas a comprensividad sofre críticas especialmente sob uma perspectiva conservadora, de pessoas situadas no campo da direita, como Tamburri (2007). A principal crítica desses setores é a de que tal princípio foi responsável pela queda do rendimento acadêmico na Espanha, ou pelo "rebaixamento do nível" de ensino, como é mais comum se falar, contribuindo para que o país se mantenha atrasado no âmbito da União Européia.

López Rupérez (2006), depois de fazer uma série de comparações internacionais por meio dos resultados do PISA (Programa Internacional de Avaliação de Alunos), aponta como responsável pelo rebaixamento do nível da educação espanhola exatamente a comprensividad implantada pela LOGSE. 
La política consistente en rebajar los niveles formativos y mantener una enseñanza, en lo esencial, unificada y comprensiva hasta los 16 años no parece haber producido, a la luz de los análisis empíricos, los resultados deseados por el legislador. (LÓPEZ RUPÉREZ, 2006, p. 84).

Embora se referindo aos anos 1970, início do tecnicismo, Carlos Lerena desvenda esse discurso historicamente recorrente, que mistura "crise cataclísmica" com o que chama de "salada de cifras" para justificar a intervenção do "cirurgião de mão de ferro" da vez.

Abonada por no pocos economistas de la educación, esta representación, que reduce la problemática educativa a su dimensión cuantitativa, viene acompañada por otra representación, tan confundidora como aquélla, que añade a la dimensión cuantitativa la idea de dêbâcle, de crisis, de una enorme crisis cataclismática y abracadabrante. (Con ello el empirista, que debe pasar por profundo, ya tiene con qué adobar su ensalada de cifras.) Descansando en nociones tales como las de diagnóstico, o sea en la creencia en instituciones enfermas, en organismos patológicos, estas representaciones tienen como efecto preparar el camino a los tratamientos por decreto del, para decirlo como Costa, cirujano de la mano de hierro y de turno. (LERENA, 1999, p. 715, grifo do autor).

Para não restar dúvidas de que lado do espectro político e ideológico espanhol partem essas críticas à LOGSE, basta ler o prefácio escrito por Pilar del Castillo $^{76}$ para o livro de Francisco López Rupérez. Em um trecho ela faz a seguinte avaliação da reforma do PSOE:

[...] es la filosofía de la LOGSE - la ley impulsada y aplicada por el Gobierno Socialista en el ano noventa y todavía en vigor - la razón esencial de los graves problemas que muestran los resultados escolares en España. La LOGSE hace gala de una "contrarazón" permanente al sustituir la idea de igualdad de oportunidades por la de igualdad de resultados, "abaratando" como consecuencia la exigencia y el esfuerzo. (In: LÓPEZ RUPÉREZ, 2006, p. VI-VII).

Esse discurso é coerente com o que propôs na Ley Orgánica de Calidad de Educación (LOCE) enquanto ministra da Educação, quando era a "cirurgiã de mão de ferro" da vez, quando, buscando matizar a comprensividad, introduz os itinerários formativos nos dois últimos anos da ESO, como veremos a seguir.

\footnotetext{
76 Maria Pilar del Castillo Vera foi ministra de Educação (2000-2004) do governo José Maria Aznar (PP). Como veremos a seguir, foi a responsável pelo lançamento da Ley Orgánica de Calidad de Educación (LOCE), de 2002, que pretendia substituir a LOGSE.
} 
López Rupérez baseou-se numa série de estatísticas para dar suporte às suas críticas. No discurso a seguir fica evidente a utilização da ideologia como legitimação, por meio da estratégia da racionalização, para fazer valer seu ponto de vista. Depois de afirmar que a educação espanhola tem estado nas últimas décadas muito condicionada ideologicamente, acrescenta:

\begin{abstract}
Por su propia naturaleza, por sus finalidades y por su condición de institución social secular, la educación está orientada, en los países avanzados, por un marco ideológico de carácter humanista que ilumina las visiones del mundo y del hombre y otorga sentido, a modo de referente, a la concepción, el desarrollo y la aplicación de las políticas. Pero esa aceptación de la ideología, en sus diferentes expresiones, como algo consustancial a las políticas educativas no significa, en modo alguno, que se haya de ignorar la reflexión sobre sus consecuencias o prescindir del análisis sistemático sobre los efectos que genera su aplicación. Sin embargo, en nuestro país se ha extendido con frecuencia una desconfianza de origen ideológico sobre los resultados y sobre su consideración. Bajo la acusación fácil de emparentamiento con la tecnocracia y el economicismo - supuestamente ajenos o escasamente sensibles a los fines superiores de la educación - y ante el temor a la transparencia y a sus efectos políticos, las aproximaciones rigurosas a la realidad de las reformas y a su impacto social, han sido a menudo orilladas o, cuando menos, insuficientemente atendidas. (LÓPEZ RUPÉREZ, 2006, p. 17).
\end{abstract}

Fala como sua análise não fosse também ideológica, busca assegurar a ela um verniz científico, matemático, como já apontou Lerena (1999), supostamente desideolizado, como se isso fosse possível. Mais uma vez: ideológica é sempre a análise dos outros.

Entretanto, nem todos se preocupam em construir esse discurso racionalista e partem para o enfrentamento ideológico mais cru, embora ainda dentro da velha concepção de que "ideológico são os outros". Um dos mestres nesse tipo de manipulação ideológica, embora, claro, apontando apenas a manipulação dos outros, é Pascual Tamburri. Sobre Álvaro Marchesi ele diz: "Marchesi es un hombre de izquierdas, extremamente moderado en las formas, pero extremamente radical en las ideas." (TAMBURRI, 2007, p. 20). Para ilustrar o enfrentamento ideológico que ocorre na Espanha, poderíamos fazer uma paráfrase desse texto invertendo as pessoas e os sinais: [Tamburri] é um homem de [direita], extremanente moderado nas formas, mas extremamente radical nas idéias.

Em seu afã de desconstruir a ideologia contida na LOGSE afirma, amenizando a responsabilidade de Marchesi: 
Pero Álvaro Marchesi no es un político profesional, y su responsabilidad es más técnica que política. La LOGSE además de su indudable fundamento filosófico y pedagógico - en suma: ideológico - en Marchesi, tiene su mentor político en don Alfredo Pérez Rubalcaba ${ }^{77}$, el ministro del PSOE que apadrinó y aplicó la ley. (TAMBURRI, 2007, p. 22).

E acrescenta: "La LOGSE es un símbolo de una manipulación ideológica de la sociedad. [...] Una ideología revolucionaria sostenida con fervor religioso y carente de base real: he ahí el constructivismo." (TAMBURRI, 2007, p. 23, 28). Tamburri tem toda razão quando afirma na introdução de seu livro: "La ventaja de la libertad de expresión es que cada uno puede contar las cosas según su opinión [...]" (2007, p. 12). O problema é que ele acredita que ideólogos são apenas os outros: os construtivistas, os esquerdistas, os partidários do PSOE.

Essa polarização político-ideológica direita versus esquerda, esse enfrentamento entre o $P P$ e o PSOE, no campo educacional redundou numa sucessão de leis, responsável pela instabilidade do sistema educativo do país. 0 que um fazia em seu mandato, o outro desfazia assim que chegava ao poder.

Marchesi (2005, p. 25-26) reclama da oposição destrutiva feita pelo $P P$ durante o mandato do PSOE (1983-1996):

Las posiciones del Partido Popular hasta 1996 fueran de oposición destructiva: nada les parecía bien. Votaron en contra de todas las leyes y de todas las iniciativas socialistas. Su modelo parecía que era el opuesto al vigente. Sus tres ejes fundamentales eran la libertad de elección de centro por parte de los padres, el cambio de la LOGSE para reducir los anos de la educación común, y la mayor financiación a la educación infantil.

Antonio Viñao não é nada otimista quanto à possibilidade de um acordo entre os dois partidos que vêm se alternando no poder, que possa trazer maior estabilidade ao sistema educativo espanhol. Aponta como responsável por isso o hecho religioso, o fato religioso:

En este país me parece inviable un pacto entre las dos fuerzas políticas (el PSOE y el PP) llamadas, por el momento, a la alternancia en el poder estatal. Sus políticas educativas podrán ser en la práctica todo lo similares o cercanas que se quiera, y en

77 Alfredo Pérez Rubalcaba foi ministro da Educação da Espanha entre 1992 e 1993. Substituiu Javier Solana (1988-1992) e foi responsável pela continuidade da aplicação da LOGSE no governo de Felipe González (PSOE). 
muchos aspectos lo son, pero hay algo que les dividirá siempre. Ese algo es lo que en otro lugar he llamado de subsistema educativo de la iglesia católica, al que ha que añadir otros centros privados, concertados o no, que no forman parte de dicho subsistema. (VIÑAO, 2006, p. 59).

De fato, quando chegou ao poder em 1996 o PP começou a minar a LOGSE, com apontou Marchesi (2005), enquanto não tinha maioria no parlamento para dar sustentação a uma mudança mais profunda. Assim que conseguiu essa maioria nas eleições de 2000, lançou uma nova reforma que pretendia revogar a LOGSE e mudar todos os pontos negativos da reforma do PSOE, tão criticados pelos conservadores. No final de 2002, Pilar del Castillo, ministra da Educação do governo de José Maria Aznar, lança a Ley Orgánica de Calidad de la Educación $(L O C E)^{78}$.

\section{Ley Orgánica de Calidad de la Educación (LOCE)}

Num regime democrático, em que vigora a liberdade de expressão, as "armas" são as palavras. E as palavras revelam e escondem intenções dependendo dos interesses de quem as expressa. Enfim, quando envolve disputa de poder político, as palavras são sempre ideológicas. Um dos sintomas mais evidentes do conflito político-ideológico e, evidentemente semântico, entre o PP e o PSOE e os respectivos "partidos ideológicos" (SAVIANI, 2006) que representam, já está na própria forma como é chamada a LOCE. Os partidários do PP chamam-na de "reforma da reforma". A reforma a ser reformada no caso é a LOGSE, feita pelo PSOE. Os partidários do PSOE, por sua vez, lançando mão do segundo modus operandi da ideologia, a "dissimulação" (THOMPSON, 2000), chamam a reforma lançada pelo PP de "contra-reforma". Por meio da estratégia do "deslocamento", buscam na História a conotação negativa do conceito de contra-reforma em suas origens religiosa e conservadora, para indicar que se trata de uma reforma reacionária, que promove um retrocesso em termos educacionais.

\footnotetext{
78 Ley Orgánica 10/2002, de 23 de diciembre, de Calidad de la Educación, publicada no Boletín Oficial del
} Estado número 307, de 24 de dezembro de 2002. 
Alguns autores tentam escapar desse maniqueísmo, distribuem críticas aos dois partidos e duvidam dessas terminologias bipartidaristas. Rozada (2002), por exemplo, acredita que desde a LOGSE (ele a chama de contra-reforma em relação à democratização vigente no início do próprio governo socialista) e especialmente a partir da $L O P E G^{79}$ e da $L O C E$, a escola pública vem perdendo espaço e a Educação é cada vez mais cooptada pelo mercado. Chega mesmo a afirmar: "Las políticas del Partido Popular y del Partido Socialista no son antagónicas en educación como no son tampoco en la economía o en la guerra" (ROZADA, 2002, p. 36). Pascual Tamburri certamente pensa o contrário, assim como no outro extremo do espectro político-ideológico, também Álvaro Marchesi. Estou mais de acordo com Antonio Viñao e o antagonismo insuperável do hecho religioso que impede o acordo entre os dois partidos.

Além disso, se José María Rozada tivesse escrito seu texto depois da vitória do PSOE em 2004, constataria que José Luis Rodriguez Zapatero retirou os soldados enviados ao Iraque em 2003 por José María Aznar do PP. Podem ser próximos na Economia, mas são diferentes na Educação e na Geopolítica.

Na primeira frase do preâmbulo da lei do $P P$, já aparece como justificativa para a reforma as mudanças tecnológicas e o papel do conhecimento como motor do desenvolvimento econômico e social, embora ainda não mencionasse explicitamente a tão falada sociedade do conhecimento:

Los cambios tecnológicos han transformado las sociedades modernas en realidades complejas, afectadas por un fuerte dinamismo que tiene en el conocimiento y en la información el motor del desarrollo económico y social. (ESPAÑA, 2002, p. 45188).

Algumas páginas a seguir, numa atualização da teoria do capital humano, destaca o papel da Educação nesse contexto de mudanças próprias da sociedade do conhecimento:

Como se ha dicho, en el contexto de una sociedad basada en el conocimiento, la educación y la formación se han convertido hoy en los elementos clave para el logro

79 A Ley Orgánica de la Participación, la Evaluación y el Gobierno de los Centros (LOPEG), foi lançada em 1995 pelo ministro Gustavo Suárez Pertierra no final do governo de Felipe González. Ficou conhecida como a lei da "77 medidas" porque em seu final foram incluídas 77 propostas que visavam a melhora da qualidade da educação (ROZADA, 2002). 
de los objetivos de progreso personal, social y económico. (ESPAÑA, 2002, p. 45190, grifo nosso).

Não há divergências entre os documentos elaborados pelos dois partidos quanto às justificativas para a reforma. Entretanto, os documentos elaborados pelos respectivos partidos divergem quanto às propostas de enfrentamento das demandas ensejadas por essas mudanças.

Puelles Benitez (2006, p. 73) aponta a contradição entre essa avançada retórica como justificativa da Lei do $P P$ e as velhas concepções de educação de corte conservador que ela propugna:

Quizá la nota más característica de la LOCE fue el contraste entre la retórica en la que se envolvió - sociedad de la información y del conocimiento, nuevas tecnologías, cultura de la evaluación, etc. - y la vieja concepción que el tratamiento de los problemas de la educación revelaba.

Não é necessário dizer de que lado do espectro político-ideológico esse autor se situa.

A LOCE reconhece os avanços recentes na educação espanhola, possibilitados pelas reformas anteriores, mas logo em seguida adverte que ainda há muitas debilidades que precisam ser sanadas, daí a nova lei. No trecho a seguir aparece o tema da baixa qualidade de ensino, especialmente na educação secundária. Como vimos, os críticos conservadores atribuem a responsabilidade disto à LOGSE. Aqui, evidentemente, a crítica à lei do PSOE é velada e cercada dos cuidados próprios do linguajar jurídico.

Las evaluaciones y los análisis de nuestro sistema educativo, efectuados por organismos e instituciones tanto nacionales como internacionales, revelan deficiencias de rendimiento preocupantes con relación a los países de nuestro entorno económico y cultural. Esas deficiencias se manifiestan, particularmente, en la Educación Secundaria. Así, una cuarta parte del alumnado no obtiene el título de Graduado en Educación Secundaria Obligatoria, y abandona el sistema sin titulación ni cualificación. Además, nuestros alumnos se sitúan por debajo de la media de la Unión Europea en sus conocimientos de materias instrumentales como las matemáticas y las ciencias, fundamentales en una realidad social y económica en la que la dimensión científicotecnológica del conocimiento es primordial. (ESPAÑA, 2002, p. 45189).

Alguns parágrafos depois aparece a resposta a outra crítica recorrentemente feita à $L O G S E$, de que ela teria, por seus ideais igualitaristas 
próprios da comprensividad, levado ao desinteresse, à desvalorização do esforço pessoal e da disciplina, o que seria a principal explicação para a suposta queda da qualidade do ensino.

Este nuevo impulso reformador que la Ley promueve se sustenta, también, en la convicción de que los valores del esfuerzo y de la exigencia personal constituyen condiciones básicas para la mejora de la calidad del sistema educativo, valores cuyos perfiles se han ido desdibujando a la vez que se debilitaban los conceptos del deber, de la disciplina y del respeto al profesor. (ESPAÑA, 2002, p. 45189).

Uma das saídas apontadas pela LOCE para a retomada do interesse pela escola e a redução das taxas de abandono na ESO, foi a implantação dos itinerários formativos. Contrariando a comprensividad herdeira da LOGSE, em seu artigo 26 a LOCE pregava a introdução de distintos itinerários formativos no terceiro e quarto cursos da ESO: dois itinerários no terceiro curso - Tecnológico e CientíficoHumanístico -, três no quarto curso - Tecnológico, Científico e Humanístico (ESPAÑA, 2002). Os itinerários suscitaram muita polêmica no país, mas com a vitória do PSOE nas eleições de 2004, a LOCE foi anulada e eles não foram implantados. Na ocasião do lançamento da lei do PP, Fernández Enguita (2002), por exemplo, publicou um artigo no jornal El País se posicionando firmemente contra os itinerários. Mais recentemente, López Rupérez (2006) lançou um livro recheado de estatísticas em que critica a LOGSE e defende a volta dos itinerários. Já Puelles Benitez (2006), em artigo em que avalia historicamente as reformas espanholas, crítica os itinerários da $\angle O C E$.

O preâmbulo da lei do PP acrescenta ainda que "la cultura del esfuerzo es una garantía de progreso personal, porque sin esfuerzo no hay aprendizaje." (ESPAÑA, 2002, p. 45189). Não custa lembrar a opinião de Pilar del Castillo no prefácio do livro de López Rupérez (2006). Deve ser recordado que ela foi a responsável pelo lançamento da $L O C E$.

Esforço e dedicação são características pessoais. Basta observar nosso entorno social para constatar que as pessoas são diferentes, que umas são mais esforçadas e dedicadas, outras menos. O ideal é que vivêssemos em uma sociedade na qual a origem de uma possível desigualdade entre as pessoas fosse apenas essa diferença individual. $O$ problema é que o mundo capitalista não 
funciona assim, especialmente quando a democracia é crescentemente cooptada pelo mercado, como denunciou Rozada (2002); as oportunidades não são iguais para todos. Tradicionalmente o pensamento liberal, de direita, encara esse problema como se fosse uma questão de caráter, algo estritamente pessoal. Portanto, não leva em conta o fato de que, por exemplo, os trabalhadores de forma geral não se identificam com a escola, que ainda segue em grande medida elitista, orientada pelos valores da classe média, e não se adaptam a ela ou muitas vezes nem mesmo vêem boas razões para se esforçarem e se dedicarem aos estudos. Como aponta Fernández Enguita (2003), pode haber uma elevada dose de racionalidade na baixa identificação instrumental dos alunos pobres com o sistema escolar porque a promessa de mobilidade social que a escola lhes oferece é, por sua própria essência, certa em termos individuais, mas incerta em termos coletivos, já que não há lugar para todos.

O pensamento de direita também não leva em conta que os conhecimentos e as competências desenvolvidos e cobrados na escola estão fortemente centrados no eixo lingüístico e lógico-matemático. Portanto, não valorizam outras inteligências, como já apontou Gardner (2000), criando dificuldades de adaptação para muitos estudantes. E, sobretudo, não considera que há desigualdades que muitas vezes não são superadas apenas com esforço pessoal, algumas das quais originadas de diferenças, como as de etnia, que contribuem muitas vezes para aprofundar a desigualdade social.

Mesmo a diferença de classe permanece um poderoso mecanismo de perpetuação da desigualdade social. Isso em parte explica porque quando há uma ampliação da escolarização, como é típico das reformas comprensivas, o rendimento acadêmico tende a cair. E isso não ocorreu apenas na Espanha, como querem fazer crer os críticos da LOGSE. Como afirma Fernández Enguita (2003, p. 24):

Los efectos de la reforma comprehensiva han sido, en cambio, medianos o mediocres por doquier, a pesar de su más larga duración y del mayor énfasis puesto en ella. Aunque sin duda ha mejorado mucho la educación de los que nos reciben, y aunque puede afirmarse que han aumentado las oportunidades de movilidad educativa, el origen de clase sigue pesando fuertemente sobre las oportunidades escolares (y también, después, sobre los efectos de estos resultados en el mercado de trabajo). 
Isso precisa ser levado em conta: com um ensino mais inclusivo, o "nível" cai em comparação com uma realidade na qual havia mais homogeneidade entre os alunos oriundos de uma elite, portanto, com maior capital cultural e melhor adaptada à escola. Mas não pode ser desprezado o fato de que mesmo que o rendimento médio caia, tem havido um avanço para a grande maioria que foi incorporada à escola. É como apropriadamente questiona Marchesi (2005, p. 70-71):

¿Se puede afirmar con seriedad que desde 1965 hasta ahora ha descendido el nivel educativo en España por la extensión en dos oleadas, 1970 y 1990, de la educación comprensiva? ¿Había más nivel en 1965, cuando estudiaba a los dieciséis años el 20 por ciento de los jóvenes de una generación, y sólo conseguía terminar la etapa educativa correspondiente algo más de la mitad de ellos, que cuando estudia la totalidad de los jóvenes y alcanzan el título en torno al 73 por ciento?

Essa avaliação saudosista (e conservadora) de que no passado a educação escolar era melhor também é comum no Brasil. Era melhor porque era mais elitista, para poucos, e, portanto, para um alunado homogêneo. O grande desafio agora, tanto na Espanha como no Brasil, como veremos, mais aqui do que lá, é aumentar a qualidade com eqüidade. Não por acaso esse é o eixo central da mais nova reforma votada na Espanha, a Ley Orgánica de Educación (LOE), que por ora está sendo posta em prática.

\section{Ley Orgánica de Educación (LOE)}

No pleito de 2004, o PP perdeu a eleição e com a vitória de José Luis Rodriguez Zapatero (PSOE), a aplicação da LOCE foi interrompida. María Jesús San Segundo, a nova ministra da Educação, deu início a elaboração de uma nova lei, a Ley Orgánica 2/2006 de Educación, de 3 de maio de 2006. Portanto, a disputa político-ideológica e semântica continua.

Ainda em 2004, o Ministério de Educación y Ciencia, produziu o documento Una educación de calidad para todos y entre todos: propuestas para el debate, com o objetivo de subsidiar as discussões na sociedade com vistas à 
votação de um Projeto de Lei de reforma educacional. A Ley Orgánica de Educación (LOE), aprovada pelo Parlamento no final de 2005, substitui a Ley Orgánica de Ordenación General del Sistema Educativo (LOGSE) de 1990 e outras leis que se seguiram a ela, incluindo evidentemente a $L O C E$ do $P P$, e institui uma nova ordenação do sistema educativo espanhol. A única lei não revogada, embora tenha sido bastante modificada, foi a Ley Orgánica del Derecho a la Educación (LODE), de 1985.

Embora possa ser considerada uma lei reformista de caráter global estrutural, curricular, organizativa e político-administrativa - a $L O E$ aproveitou das reformas anteriores o que seus elaboradores julgaram positivo, especialmente do ponto de vista estrutural:

La Ley parte de los avances que el sistema educativo ha realizado en las últimas décadas, incorporando todos aquellos aspectos estructurales y de ordenación que han demostrado su pertinencia y su eficacia y proponiendo cambios en aquellos otros que requieren revisión. Se ha huido de la tentación de pretender cambiar todo el sistema educativo, como si se partiese de cero, y se ha optado, en cambio, por tener en cuenta la experiencia adquirida y los avances registrados. (ESPAÑA, 2006a, p. 17161).

A $L O E$, embora tenha revogado a $L O G S E$, manteve a mesma estrutura e ordenação do sistema criada pela reforma de 1990. As mudanças foram pontuais: estendeu a gratuidade até o segundo ciclo da educação infantil (3 a 6 anos), a educação primária permanece com 6 anos e a secundária obrigatória (ESO), com 4 anos. Entretanto, abriu a possibilidade de diversificação no final da ESO:

La educación secundaria obligatoria debe combinar el principio de una educación común con la atención a la diversidad del alumnado, permitiendo a los centros la adopción de las medidas organizativas y curriculares que resulten más adecuadas a las características de su alumnado, de manera flexible y en uso de su autonomía pedagógica. Para lograr estos objetivos, se propone una concepción de las enseñanzas de carácter más común en los tres primeros cursos, con programas de refuerzo de las capacidades básicas para el alumnado que lo requiera, y un cuarto curso de carácter orientador, tanto para los estudios postobligatorios como para la incorporación a la vida laboral. (ESPAÑA, 2006a, p. 17162).

Trata-se de uma flexibilização do princípio da comprensividad, maior do que já ocorria sob a LOGSE. Aliás, chama a atenção o fato de essa palavra nem aparecer no texto da nova lei. Pode ser uma concessão, após tantas críticas, ou 
uma "dissimulação", por meio da estratégia de "eufemização". O novo documento passa a falar em princípio de inclusividad:

La adecuada respuesta educativa a todos los alumnos se concibe a partir del principio de inclusión, entendiendo que únicamente de ese modo se garantiza el desarrollo de todos, se favorece la equidad y se contribuye a una mayor cohesión social. La atención a la diversidad es una necesidad que abarca a todas las etapas educativas $y$ a todos los alumnos. (ESPAÑA, 2006a, p. 17163, grifo nosso).

Uma mudança curricular significativa ocorreu no bachillerato, que é cursado nos mesmos dois anos da estrutura anterior. Na LOGSE havia quatro modalidades a serem escolhidas pelos estudantes que pretendiam ingressar na universidade: Ciências da Natureza e da Saúde; Tecnologia; Humanidades e Ciências Sociais; Artes (rever o quadro 5). Como mostra o quadro 8, com a entrada da $L O E$ em vigor essas modalidades ficaram reduzidas a três:

- Artes;

- Ciências e Tecnologia;

- Humanidades e Ciências Sociais. 


\section{Quadro 8. Sistema Educativo LOE}

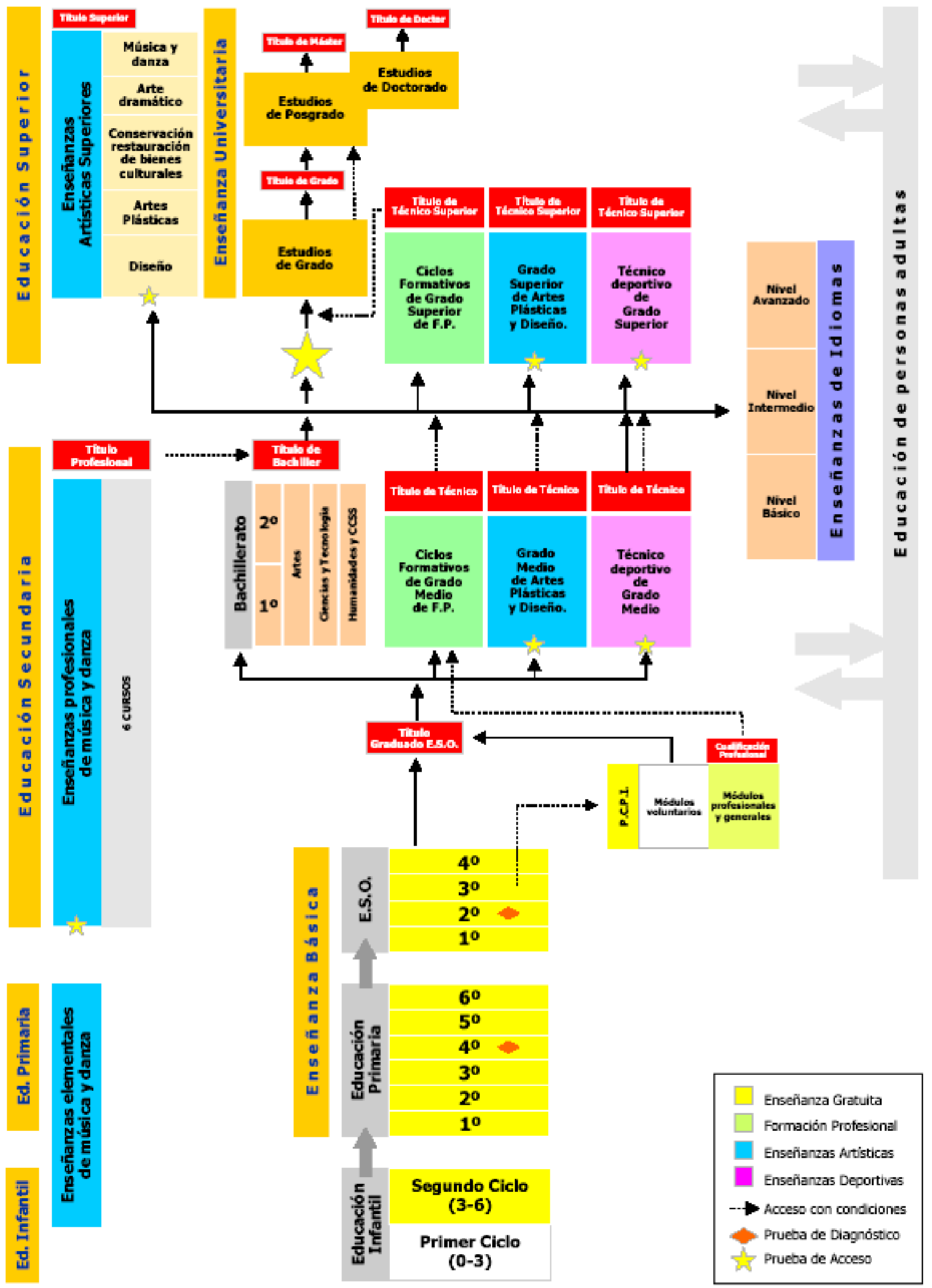

Fonte: Ministerio de Educación y Ciencia. Sistema Educativo LOE. Disponível em:

<www.mec.es/educa/sistema-educativo/loe/sistema-educativo-loe.html>. Acesso em: 8 fev. 2008. 
Dentre as várias justificativas para a implantação dessa nova lei está a necessidade de adaptação à sociedade do conhecimento e às propostas da União Européia e da UNESCO, como fica evidente no seguinte trecho do preâmbulo:

A la vista de la evolución acelerada de la ciencia y la tecnología y el impacto que dicha evolución tiene en el desarrollo social, es más necesario que nunca que la educación prepare adecuadamente para vivir en la nueva sociedad del conocimiento y poder afrontar los retos que de ello se derivan.

Es por ello por lo que en primer lugar, la Unión Europea y la UNESCO se han propuesto mejorar la calidad y la eficacia de los sistemas de educación e de formación, lo que implica mejorar las capacitación de los docentes, desarrollar las aptitudes necesarias para la sociedad del conocimiento [...] (ESPAÑA, 2006a, p. 17160, grifo nosso).

Mesmo um crítico da $L O E$, Francisco López Rupérez, que a considera herdeira direta da LOGSE, também justifica a necessidade da reforma recorrendo a argumentos muito parecidos:

En pleno auge de la sociedad del conocimiento y de la información, cuando las demandas que traslada la globalización a los sistemas de educación y formación para el logro de sociedades más justas, capaces de conciliar desarrollo personal, progreso económico y cohesión social, se hacen más patentes; en pleno impulso político de la Unión Europea para la modernización de sus sistemas educativos y la mejora de su calidad, la educación española se encuentra en un momento histórico de gran incertidumbre, desorientación e inestabilidad. (LÓPEZ RUPÉREZ, 2006, p. 13, grifo do autor).

Muitos autores tendem a ver isso como uma necessidade de adaptação às injunções do mercado, e a coincidência de pontos de vista à esquerda e à direita do espectro político só reforçaria isso. Gimeno Sacristán, por exemplo, ao analisar as reformas efetuadas na Espanha, confirma essa vinculação entre as reformas educacionais e as necessidades do sistema socioeconômico. Afirma que "em nossa tradição e no campo jurídico administrativo, as reformas curriculares vão ligadas a mudanças na estrutura do sistema mais que a um debate permanente sobre as necessidades do sistema educativo". (GIMENO SACRISTÁN, 2000, p. 20).

Embora centrando sua análise na realidade brasileira, Gaudêncio Frigotto também tem a contribuir nesse debate. Ele remete-se a Marx, quando este critica a perspectiva educacional dos economistas filantropos ${ }^{80}$, para denunciar como

80 "O verdadeiro significado da educação, para os economistas filantropos, é a formação de cada operário no maior número possível de atividades industriais, de tal sorte que se é despedido de um trabalho pelo emprego 
ideológico o conceito de sociedade do conhecimento. Para Frigotto (2003), a tese de que uma economia global na qual o principal recurso é o conhecimento, que não teria limites e estaria ao alcance de todos, opera dentro de um nível profundamente apologético e ideológico. E acrescenta que isso estaria associado ao discurso neoliberal:

Se as perspectivas filantrópicas persistem, de várias formas, e retomam força no interior do ajuste neoliberal, como a tese da sociedade do conhecimento que transforma o proletariado em "cognitariado", elas convivem com demandas que o inventário da literatura internacional e nacional identifica como uma nova "qualidade" da educação escolar e dos processos de qualificação ou requalificação da força de trabalho. (FRIGOTTO, 2003, p. 140-141).

Além de Frigotto (2003) e Gimeno Sacristán (2000) há outros autores brasileiros e espanhóis, como Ramos (2002a) e Beltrán Duarte (2000), que criticam a instrumentalização da Educação pelo sistema produtivo.

Como já observei antes, as avaliações do PSOE e do PP convergem, pois ambos mencionam a necessidade de se adaptar à sociedade do conhecimento como justificativa para suas respectivas reformas. Ambos evidentemente também defendem a necessidade de elevação da qualidade do ensino oferecido aos estudantes, compatibilizando-a com maior eqüidade. Aliás, tendo a achar que Rozada (2002) tinha razão quando afirmou não haver diferença entre as propostas do PSOE e do PP no campo da Educação, pelo menos na linguagem formal dos documentos jurídicos. Veja o que diz a $L O E$ :

A pesar de estos logros indudables, desde mediados de la década de los noventa se viene llamando la atención acerca de la necesidad de mejorar la calidad de la educación que reciben nuestros jóvenes. La realización de diversas evaluaciones acerca de la reforma experimental de las enseñanzas medias que se desarrolló en los años ochenta y la participación española en algunos estudios internacionales a comienzos de los noventa evidenciaron unos niveles insuficientes de rendimiento, sin duda explicables, pero que exigían una actuación decidida. En consecuencia, en 1995 se aprobó la Ley Orgánica de la Participación, la Evaluación y el Gobierno de los Centros Docentes, con el propósito de desarrollar y modificar algunas de las disposiciones establecidas en la LOGSE orientadas a la mejora de la calidad. En el año 2002 se quiso dar un paso más hacia el mismo objetivo, mediante la promulgación de la Ley Orgánica de Calidad de la Educación. (ESPAÑA, 2006a, p. 17159). 
É interessante a linguagem cifrada constante dos documentos jurídicos e, portanto, ideológica, porque, muitas vezes, reificada. Como já apontou Thompson (2000), uma das estratégias de manifestação da ideologia como "reificação" é a "passivização". Com essa estratégia desaparecem os atores e os sujeitos, os processos aparecem como coisas e, conseqüentemente, desaparecem os conflitos de interesses e as contradições. Por exemplo, no trecho acima se afirma que "desde mediados de la década de los noventa se viene llamando la atención acerca de la necesidad de mejorar la calidad de la educación". Quem vem chamando a atenção? Sobretudo os críticos da LOGSE, que são majoritariamente do campo conservador, partidários do PP. Em seguida é dito que "en 1995 se aprobó la Ley Orgánica de la Participación, la Evaluación y el Gobierno de los Centros Docentes, con el propósito de desarrollar y modificar algunas de las disposiciones establecidas en la LOGSE orientadas a la mejora de la calidad". Quem aprovou essa lei? Foi o PSOE, de certa forma concedendo a pressões do campo conservador e do mercado, como apontam críticos de esquerda, como Rozada (2002). Finalmente, afirma-se que: "En el año 2002 se quiso dar un paso más hacia el mismo objetivo, mediante la promulgación de la Ley Orgánica de Calidad de la Educación." Quem quis dar um passo em direção ao mesmo objetivo (da qualidade) e para isso aprovou a LOCE? O PP, adversário do $P S O E$. Ora, se a $L O C E$ tinha esse objetivo, se supostamente era boa, por que foi abortada pelo PSOE logo que chegou ao poder? Como se vê, a linguagem pode esconder e revelar interesses conflitantes, pode mascarar estratégias de construção simbólica na disputa pelo poder, numa palavra, pode ser ideológica.

Em seguida, vem um trecho em que se reforça a necessidade da busca da qualidade, entretanto sem abrir mão da eqüidade. Aqui vai uma crítica velada às propostas do $P P$, própria de uma visão liberal, que teriam focado demasiadamente na qualidade, sem se aterem à eqüidade.

En los comienzos del siglo XXI, la sociedad española tiene la convicción de que es necesario mejorar la calidad de la educación, pero también de que ese beneficio debe llegar a todos los jóvenes, sin exclusiones. Como se ha subrayado muchas veces, hoy en día se considera que la calidad y la equidad son dos principios indisociables. 
Algunas evaluaciones internacionales recientes han puesto claramente de manifiesto que es posible combinar calidad y equidad y que no deben considerarse objetivos contrapuestos. (ESPAÑA, 2006a, p. 17159).

A busca de qualidade com eqüidade é um dos três princípios fundamentais da LOE: 1) educação de qualidade para todos; 2) ideal de esforço compartido; 3) compromisso com os objetivos educativos da União Européia. Vejamos cada um deles.

"El primero consiste en la exigencia de proporcionar una educación de calidad a todos los ciudadanos de ambos sexos, en todos los niveles del sistema educativo." (ESPAÑA, 2006a, p. 17159). A preocupação com a qualidade é relativamente recente nos documentos das reformas ocorridas na Espanha, pois só passa a constar na LOGSE. De acordo com Marchesi (2005, p. 14):

Curiosa o sorprendentemente, en las leyes básicas que han tenido un extenso desarrollo, aprobadas respectivamente en 1970 y 1984, la Ley General de Educación (LGE) y la Ley Orgánica del Derecho a la Educación (LODE), no se habla en ningún momento de la calidad de la enseñanza. No sólo en las propias leyes tampoco en las normas posteriores.

Isso se deve a dois motivos interrelacionados. Até a $L O D E$ a preocupação era quantitativa, era garantir a universalização da escolarização básica. Assegurado isso, o próximo passo inevitavelmente seria a elevação da qualidade, o que coincide com a entrada do capitalismo em sua etapa informacional-global (CASTELLS, 2000), marcada pela terceira revolução industrial e pela produção flexível (HARVEY, 1993), e o momento em que se disseminam os conceitos de globalização e de sociedade do conhecimento.

Indissoluvelmente atrelado ao primeiro princípio, o segundo prega a necessidade de um esforço compartido para se atingir a qualidade e a eqüidade no sistema educativo:

El segundo principio consiste en la necesidad de que todos los componentes de la comunidad educativa colaboren para conseguir ese objetivo tan ambicioso. La combinación de calidad y equidad que implica el principio anterior exige ineludiblemente la realización de un esfuerzo compartido. (ESPAÑA, 2006a, p. 17159).

Em seguida, novamente o documento elaborado sob o governo do PSOE lança mão da estratégia da "passivização" - "com freqüência se vem insistindo no 
esforço dos estudantes" - para fazer mais uma crítica velada aos seus adversários os partidários do $P P$ e a lgreja Católica, que em geral são os defensores do esforço pessoal - e à própria $L O C E$, na qual esse princípio estava expresso:

Con frecuencia se viene insistiendo en el esfuerzo de los estudiantes. Se trata de un principio fundamental, que no debe ser ignorado, pues sin un esfuerzo personal, fruto de una actitud responsable y comprometida con la propia formación, es muy difícil conseguir el pleno desarrollo de las capacidades individuales. Pero la responsabilidad del éxito escolar de todo el alumnado no sólo recae sobre el alumnado individualmente considerado, sino también sobre sus familias, el profesorado, los centros docentes, las Administraciones educativas y, en última instancia, sobre la sociedad en su conjunto, responsable última de la calidad del sistema educativo. (ESPAÑA, 2006a, p. 17159).

Enfim, a $L O E$ faz mais uma concessão ao incorporar a idéia do esforço pessoal, que tem muito apelo especialmente em setores da classe média. Entretanto, redistribui responsabilidades: tira o foco da avaliação personalista e passa a falar em "esforço compartido", o que é menos liberal, o que está mais de acordo com os ideais social-democratas do PSOE.

O terceiro princípio norteador da $L O E$ insiste em um ponto que já vem obtendo destaque desde a LOGSE, passando pela LOCE: a necessidade de se convergir com os padrões educacionais vigentes nos países mais ricos da União Européia.

El tercer principio que inspira esta Ley consiste en un compromiso decidido con los objetivos educativos planteados por la Unión Europa para los próximos años. El proceso de construcción europea está llevando a una cierta convergencia de los sistemas de educación y formación, que se ha traducido en el establecimiento de unos objetivos educativos comunes para este inicio del siglo XIX. (ESPAÑA, 2006a, p. 17160).

Neste ponto não há divergências importantes entre os partidários do $P S O E$ e do PP. Na Espanha há um difuso sentimento de insatisfação diante do fato de o país ser a quinta economia da União Européia e obter rendimentos acadêmicos relativamente baixos nas provas do PISA, abaixo da média da OCDE, como mostra a figura 2. 
Figura 2. Distribuição do rendimento dos alunos em matemática - PISA 2003

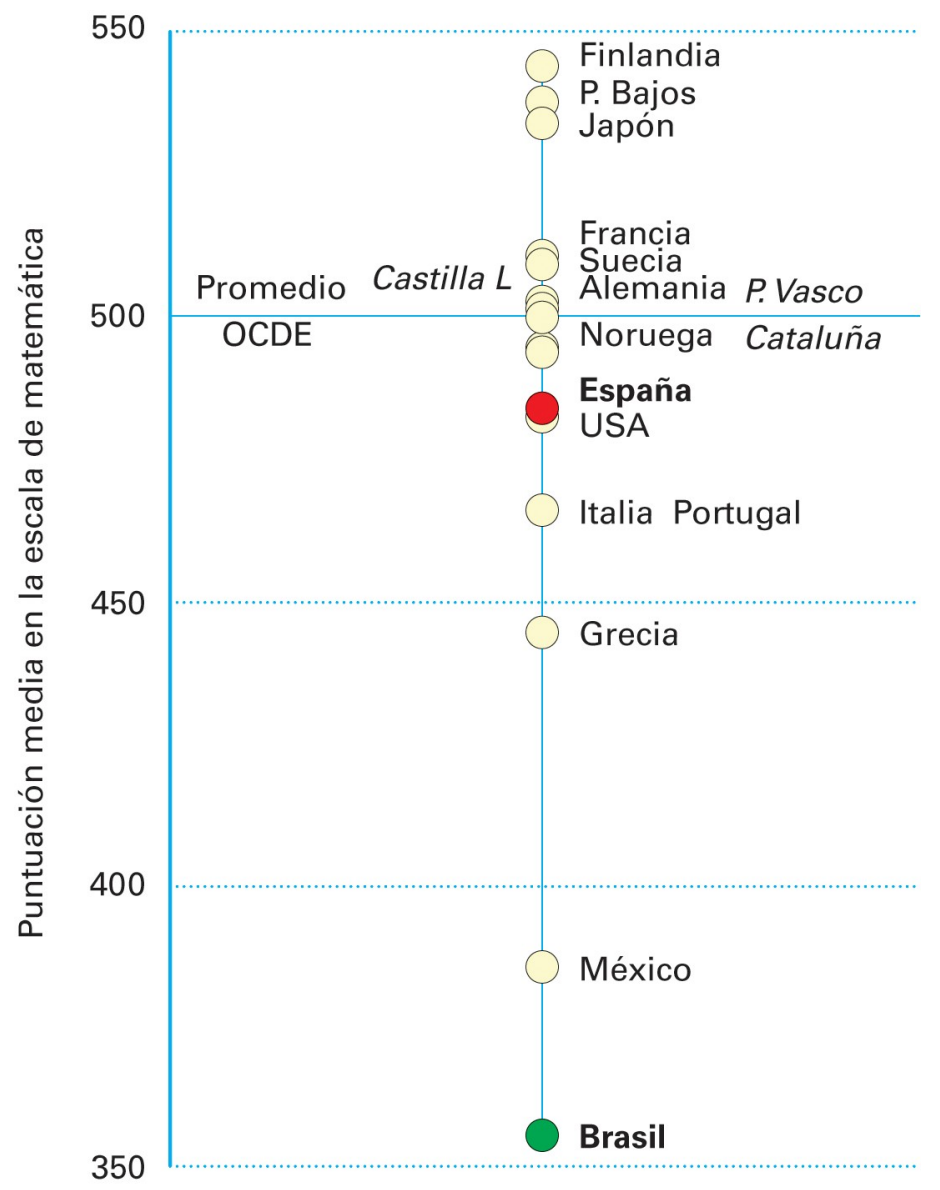

Fonte: Panorama de la Educación. Indicadores de la OCDE 2007 (ESPAÑA, 2007d, p. 19).

Outra inovação da $L O E$ foi a introdução de oito competências básicas e também da disciplina "Educação para a cidadania e os direitos humanos", que tem sido motivo de acirrados debates e enfrentamentos ideológicos. Mas, como se tratam de mudanças no plano curricular, deixemos para analisá-las no capítulo 2 da parte III, no qual serão discutidas as mudanças curriculares, com especial atenção à disciplina Geografia. 


\section{Comparação entre o Brasil e a Espanha}

Apesar de muitos pontos em comum e de certa proximidade históricocultural, Brasil e Espanha são países muito diferentes em vários aspectos e isso deve ser considerado em qualquer comparação que se queira estabelecer entre eles, especialmente no campo educacional. Há grandes diferenças demográficas, territoriais, socioeconômicas, políticas e, conseqüentemente, educacionais. Não tenho a intenção de fazer uma comparação estatística exaustiva, nem é o objetivo desta pesquisa, mas alguns dados são importantes para evidenciar essas diferenças.

Comecemos pela demografia, porque as pessoas são 0 maior patrimônio ${ }^{81}$ de uma nação. De acordo com o World Development Report 2008 (THE WORD BANK, 2007), em 2006 a população total do Brasil era de 189 milhões de habitantes, a da Espanha era de 44 milhões. Com isso o número de estudantes no sistema de ensino brasileiro é muito maior que no espanhol.

No Brasil, em 2006, o total de estudantes na educação básica - ensino infantil, fundamental e médio; educação especial, educação de jovens e adultos (EJA) e educação profissional - era de 55.942.047, sob a responsabilidade de 2.647.414 professores, distribuídos por 203.973 estabelecimentos de ensino (INEP, 2007a).

Na Espanha, no ano letivo 2006-2007, o total de estudantes na educação infantil, primária e secundária (ESO, bachillerato e formação profissional) do regime geral era de 7.081 .682 , sob a responsabilidade de 607.540 professores, distribuídos por 23.678 centros de ensino (ESPAÑA, 2007c).

Para se ter uma idéia do quão maior é o sistema de educação básica brasileiro, basta lembrar que em 2006 apenas o alunado do ensino médio 8.906.820 (INEP, 2007a) - é bem superior ao total de estudantes de toda a

81 Quando pensava sobre qual palavra utilizar aqui me vieram à cabeça "ativo", "recurso", "riqueza", "bem". É incrível como quase sempre pensamos a população (que procurei substituir por pessoas porque população é um termo com conotação estatística) de um território sob uma perspectiva economicista, instrumental. Optei por "patrimônio", que de todo modo, é também um termo econômico. O economicismo e a matematização estatística despersonalizam as pessoas. 
educação básica espanhola. Somente na EJA - modalidade não existente na Espanha, já que esse país praticamente resolveu o problema da defasagem e do analfabetismo - eram 5.616.291 alunos matriculados em 2006. Para evidenciar os desafios a serem encarados pela educação brasileira: somente a EJA é quase do tamanho de toda a educação básica espanhola.

Nessa comparação entre Brasil e Espanha é importante levar em conta duas diferenças óbvias, porém importantes: a localização geográfica e a extensão territorial.

A localização geográfica é importante porque define relações de vizinhança - de cooperação e de conflito - e a inserção regional dos países. O Brasil é um país latino-americano, da América do Sul, com vínculos mais fortes com seus vizinhos, especialmente os do Mercosul. A Espanha é um país europeu, do mediterrâneo, cada vez mais integrado à União Européia, bloco econômico supranacional que tem tido um crescente papel normatizador em diversos setores, inclusive no educacional.

A área do território brasileiro é de 8,5 milhões de $\mathrm{km}^{2} \mathrm{e}$ a da Espanha é de 506 mil km². Para facilitar a comparação: o Estado de Minas Gerais tem uma área de $586 \mathrm{mil} \mathrm{km}^{2}$ ( $4^{\circ} \mathrm{em}$ extensão no país), em seu território caberia a Espanha e Portugal quase todo. Ou seja, o Brasil possui um território 17 vezes maior que o da Espanha. Em tempos de globalização, muitos podem pensar que território e população não têm mais importância, que o Estado nacional não é mais relevante (IANNI, 1994; OHMAE, 1996), mas vale lembrar que o Brasil só é o "B" dos "BRIC"82 graças à sua enorme população, ao seu extenso território e, claro, ao seu grande mercado consumidor e elevado potencial econômico.

Entretanto, território gigantesco e população enorme geram dificuldades de tamanho proporcional em termos de infra-estrutura, de logística e de gestão. Não é uma tarefa simples gerir o gigantesco sistema educacional brasileiro, por mais que a gestão seja compartilhada e colaborativa entre as esferas federal, estadual e

82 Acrônimo criado em 2001 pelo economista Jim O'Neill, então analista de mercados do Banco Goldman Sachs, para definir as maiores economias emergentes e principais candidatos à potência mundial. São eles Brasil, Rússia, Índia e China, formando a sigla BRIC. Esse acrônimo também lembra tijolo (brick, em inglês) remetendo à idéia de que sobre essas economias os investidores internacionais irão apoiar suas estratégias de investimentos. (Câmara dos Deputados. BRIC. Disponível em: <www2.camara.gov.br/fiquePorDentro/temasanteriores/bric/apres.html>. Acesso em: 22 out. 2008. 
municipal como prega o Título IV. Da organização da educação nacional da LDB 9394/96.

Além disso, como vimos na introdução, o Brasil é um país relativamente mais pobre que a Espanha, logo, aqui há menos dinheiro para se investir. De acordo com o relatório de 2008 do Banco Mundial (THE WORLD BANK, 2007), em 2006 o PNB per capita do Brasil era de 4.730 dólares, ou 8.800 dólares, se for considerada a Paridade de Poder de Compra (PPC) ${ }^{83}$; o da Espanha era de 27.570 dólares ou 28.030 dólares PPC.

Em 2005, a Espanha investiu 38,5 bilhões de euros em Educação em todos os níveis do sistema, número que correspondia a 4,24\% do PIB daquele ano (ESPAÑA, 2007c). No mesmo ano, nas três esferas de governo, o Brasil investiu 87,5 bilhões de reais, o que correspondia a $4,5 \%$ do PIB (INEP, 2008). Considerando a taxa de câmbio de 2,77 reais por 1,00 euro em 30/12//2005 ${ }^{84}$, a Espanha despendeu o equivalente a 98,3 bilhões de reais. Ou seja, o país ibérico investiu mais em termos absolutos e principalmente em termos relativos, levando em conta que, como foi visto, seu sistema educacional é bem menor que o brasileiro. Em 2005 o Brasil despendeu 1.700 reais por aluno em todo o sistema de ensino. Considerando apenas a educação básica, o investimento foi de 1.440 reais (sendo 1.004 reais no ensino médio), ao passo que no ensino superior foi de 11.418 reais (INEP, 2008). Aqui há uma clara distorção, é preciso investir mais na educação básica, especialmente no ensino médio, o nível em que menos se gastou por aluno. O Brasil investe mais até do que a Espanha em educação superior (ver tabela 12).

Não disponho de números correlatos para o sistema educativo espanhol no ano de 2005 (ver tabela 13 com dados comparativos para 2003). De qualquer forma, devido ao descompasso entre os dois sistemas (ver quadro 9), a comparação por nível de ensino fica prejudicada, como veremos a seguir. Entretanto, é evidente que os investimentos per capita são muito mais elevados no sistema educativo espanhol. O cálculo é simples: dividindo-se as despesas totais de $2005-38,511$

\footnotetext{
83 "Uma taxa de câmbio que dá conta da variação de preços nos vários países, permitindo efetuar comparações internacionais de produção e rendimentos reais. À taxa da PPC em dólares americanos (tal como usada neste Relatório), existe um igual poder de compra com 1 dólar americano na economia interna e na economia dos EUA." (PNUD, 2007, p. 372).

84 Banco Central do Brasil. Conversão de moedas. Disponível em: <www4.bcb.gov.br/pec/conversao/Resultado.asp?idpai=convmoeda>. Acesso em: 25 set. 2008.
} 
bilhões de euros - pelo total de alunos matriculados em todos os níveis do sistema de ensino naquele ano - 8.487.576 (ESPAÑA, 2007c) - o resultado é um investimento per capita de 4.537 euros (cerca de 12.500 reais ao câmbio da época). Isso é cerca de 7 vezes o que o Brasil investiu per capita em todo seu sistema educacional naquele ano. Evidentemente que essas disparidades redundam em indicadores educacionais muito diferentes, como veremos a seguir, e também em desempenhos diversos em avaliações externas (ver figura 2).

Como Vilanovas Ribas e Moreno Julià (1992) já no informaram, em 1970, quando a Espanha elaborou a Ley General de Educación (LGE), a taxa de analfabetismo no país era de 9,0\%; no Brasil, quando foi elaborada a LDB 5692/71, o índice de analfabetos era de 31,6\% (DIEESE, 2007). Segundo o Relatório de Desenvolvimento Humano 2007/2008 (PNUD, 2007), em 2005 o analfabetismo no Brasil ainda era da ordem de 11,4\%, enquanto que o da Espanha era residual, inferior a $1 \%{ }^{85}$. Conforme projeções do DIEESE (2007) somente em 2010 o Brasil deve atingir uma taxa de analfabetos de 9,6\%, número próximo ao da Espanha de 1970.

Vejamos algumas informações comparativas sobre o ensino médio. De acordo com o PNUD (2007), em 2005 a taxa líquida de escolarização ${ }^{86}$ secundária no Brasil era de $78 \%$, enquanto que na Espanha era de $98 \%$. Nesse país, a taxa de graduação $^{87}$ no ensino secundário no ano letivo 2004/2005 foi de: na ESO, 77,5\% para as mulheres e $63,7 \%$ para os homens (média: 70,6\%); no bachillerato, $52,5 \%$ para as mulheres e $36,7 \%$ para os homens (média: 44,6\%) (ESPAÑA, 2007c). No Brasil, em 2005, a taxa de graduação no ensino médio foi de 64\% (ESPAÑA,

85 No relatório do PNUD para diversos países de alto desenvolvimento humano não aparece a taxa de alfabetização de adultos com 15 ou mais anos, mas o símbolo “..” e o comentário: "Para calcular o IDH, foi considerado um valor de 99,0\%." (PNUD, 2007, p. 234). Donde se conclui que a taxa de analfabetismo considerada é de $1 \%$.

86 "Número de alunos pertencentes a uma faixa etária oficialmente indicada para o nível de ensino em que se encontram matriculados, representado como uma percentagem da população com a idade escolar oficialmente indicada para o seu nível." (PNUD, 2007, p. 368). Ou seja, é um indicador que identifica o percentual da população de uma determinada faixa etária matriculada no nível de ensino adequado a essa mesma faixa etária.

87 Porcentagem de graduados em determinado nível de ensino em relação ao total da população que tem a idade ideal para a conclusão desse mesmo nível. É um índice utilizado para avaliar os resultados do sistema educativo. 
2007d). Em 2005, na Espanha, a população de 25 a 34 anos com pelo menos a educação secundária era de 64\%; no Brasil, era de 38\% (ESPAÑA, 2007d).

Como se vê, a comparação simétrica entre o ensino médio brasileiro e a educação secundária espanhola não é viável sob diversos aspectos. No Brasil, esse nível do sistema educativo conta com um único ciclo de 3 anos; na Espanha, são dois ciclos: a educação secundária obrigatória (ESO), de 4 anos, e a pós-obrigatória (bachillerato), de 2 anos. Portanto, o número de anos e as faixas etárias são completamente diferentes, como mostra o quadro 9. A ESO espanhola corresponde no sistema brasileiro ao $7^{\circ}, 8^{\circ}$ e $9^{\circ}$ anos do ensino fundamental e ao $1^{\circ}$ ano do ensino médio. $O$ bachillerato corresponde aos dois anos finais do ensino médio.

\begin{tabular}{|c|c|c|c|c|c|c|c|}
\hline \multicolumn{8}{|c|}{ Quadro 9. Sistemas educacionais: Brasil e Espanha } \\
\hline \multicolumn{4}{|c|}{ Brasil (LDB 9394/96)* } & \multicolumn{4}{|c|}{ Espanha ( $L O E$, regime geral) } \\
\hline $\begin{array}{l}\text { Idade } \\
\text { ideal }\end{array}$ & ano & \multicolumn{2}{|c|}{ nível de ensino } & $\begin{array}{l}\text { Idade } \\
\text { ideal }\end{array}$ & curso & \multicolumn{2}{|c|}{ nível de ensino } \\
\hline $0-5$ & $1^{\circ}-6^{\circ}$ & \multicolumn{2}{|c|}{ educação infantil } & $0-5$ & $1^{\circ}-6^{\circ}$ & \multicolumn{2}{|c|}{ educação infantil } \\
\hline 6 & $1^{\circ}$ & \multirow{2}{*}{\multicolumn{2}{|c|}{ ensino fundamental }} & 6 & $1^{\circ}$ & \multicolumn{2}{|c|}{ educação primária } \\
\hline 7 & $2^{\circ}$ & & & 7 & $2^{\circ}$ & \multirow{5}{*}{\multicolumn{2}{|c|}{$\begin{array}{l}\text { obs.: a educação infantil é } \\
\text { voluntária; a primária e a } \\
\text { secundária obrigatória compõem a } \\
\text { educação básica obrigatória }\end{array}$}} \\
\hline 8 & $3^{\circ}$ & \multirow{2}{*}{\multicolumn{2}{|c|}{$\begin{array}{l}\text { obs.: a educação infantil é } \\
\text { voluntária; o ensino } \\
\text { fundamental e o médio }\end{array}$}} & 8 & $3^{\circ}$ & & \\
\hline 9 & $4^{\circ}$ & & & 9 & $4^{\circ}$ & & \\
\hline 10 & $5^{\circ}$ & \multirow{3}{*}{\multicolumn{2}{|c|}{$\begin{array}{l}\text { compõem o ensino básico, } \\
\text { mas só o fundamental é } \\
\text { obrigatório }\end{array}$}} & 10 & $5^{\circ}$ & & \\
\hline 11 & $6^{\circ}$ & & & 11 & $6^{\circ}$ & & \\
\hline 12 & $7^{\circ}$ & & & 12 & $1^{\circ}$ & \multirow{3}{*}{\multicolumn{2}{|c|}{$\begin{array}{l}\text { educação secundária } \\
\text { obrigatória (ESO) }\end{array}$}} \\
\hline 13 & $8^{\circ}$ & & & 13 & $2^{\circ}$ & & \\
\hline 14 & $9^{\circ}$ & & & 14 & $3^{\circ}$ & & \\
\hline 15 & $1^{\circ}$ & \multirow{3}{*}{$\begin{array}{l}\text { ensino } \\
\text { médio } \\
\text { regular }\end{array}$} & \multirow{3}{*}{\begin{tabular}{|l|} 
educação \\
profissional \\
de nível \\
médio
\end{tabular}} & 15 & $4^{\circ}$ & \multirow{3}{*}{$\begin{array}{l}\text { bachille- } \\
\text { rato }\end{array}$} & \multirow{3}{*}{$\begin{array}{l}\text { Formação } \\
\text { profissional (FP) } \\
\text { de grau médio }\end{array}$} \\
\hline 16 & $2^{\circ}$ & & & 16 & $1^{\circ}$ & & \\
\hline 17 & $3^{\circ}$ & & & 17 & $2^{\circ}$ & & \\
\hline \multirow[t]{3}{*}{$18 \ldots$} & & \multirow{3}{*}{\multicolumn{2}{|c|}{ ensino superior }} & $18 \ldots$ & & \multirow{3}{*}{$\begin{array}{l}\text { educação } \\
\text { universi- } \\
\text { tária }\end{array}$} & bachillerato \\
\hline & & & & & & & $\begin{array}{l}\text { FP de grau } \\
\text { superior }\end{array}$ \\
\hline & & & & & & & $\begin{array}{l}\text { educação } \\
\text { universitária }\end{array}$ \\
\hline
\end{tabular}

Fonte: BRASIL, Ministério da Educação. Disponível em: <http://portal.mec.gov.br>. Acesso em: 10 jan. 2007; ESPAÑA. Ministério de Educación y Ciencia. Disponível em: <www.mec.es>. Acesso em: 10 jan. 2007.

* De acordo com a Lei n. 11.274 de 6 de fevereiro de 2006 que estabeleceu o ensino fundamental de 9 anos com matrícula obrigatória a partir dos 6 anos de idade. 
Mais um exemplo dessa dificuldade de comparação da educação secundária do sistema espanhol, e não apenas com o Brasil, pode ser visto na tabela 12, que mostra o gasto com educação segundo o nível de ensino. Para ampliar a comparação incluirei mais dois países: o que mais gasta e o que menos gasta com Educação do ensino primário ao superior dentre os quinze da tabela elaborada pelo DIEESE.

\begin{tabular}{|l|c|c|c|c|c|}
\hline \multicolumn{5}{|c|}{$\begin{array}{c}\text { Tabela 12. Gasto* com educação por estudante em países } \\
\text { selecionados, segundo o nível de ensino (2003, em US\$) }\end{array}$} \\
\hline \hline \multirow{2}{*}{ País } & \multicolumn{2}{|c|}{ ensino fundamental } & \multirow{2}{*}{$\begin{array}{c}\text { ensino } \\
\text { médio }\end{array}$} & $\begin{array}{c}\text { ensino } \\
\text { superior }\end{array}$ & $\begin{array}{c}\text { do primário } \\
\text { ao superior }\end{array}$ \\
\cline { 2 - 3 } & $1^{\mathrm{a}}$ a $4^{\mathrm{a}}$ série & $5^{\mathrm{a}}$ a $8^{\mathrm{a}}$ série & & & \\
\hline Brasil & 870 & 1.105 & 1.152 & 10.054 & 1.242 \\
\hline Espanha & 4.829 & - & - & 8.943 & 6.346 \\
\hline Suíça & 8.131 & 9.538 & 15.014 & 25.900 & 12.071 \\
\hline Índia & 368 & 375 & 1.182 & 2.243 & 586 \\
\hline
\end{tabular}

Fonte: Anuário da qualificação social e professional 2007 (DIEESE, 2007, p. 111).

* O DIEESE usa o termo "gasto" e não "investimento".

Como mostra o quadro 9, no Brasil apenas o ensino fundamental (de 9 anos desde 2006, até então era de 8 anos) é obrigatório. Na Espanha são 10 anos de ensino obrigatório (6 da educação primária e 4 da ESO). A diferença maior, entretanto, está no ensino médio.

$\mathrm{Na}$ Espanha, depois da ESO, que tem um caráter comprensivo, há dois itinerários muito definidos: um propedêutico, o bachillerato, outro técnico, a formação profissional de grau médio. Nesse país há uma clara opção para o estudante que não quer ou não pode ir para a universidade. No Brasil, como vimos, são poucas as opções de profissionalização de nível médio para os estudantes que não querem ou não podem ir para a universidade.

$\mathrm{Na}$ Espanha o número de estudantes matriculados na formação profissional de grau médio no ano letivo 2007/2008 era de 500.545 (75,6\% deles em escolas públicas), o que correspondia a $44,5 \%$ do total de estudantes do ensino secundário pós-obrigatório (ESPAÑA, 2007c). No Brasil, no ano letivo 2006, o total de estudantes matriculados no ensino profissionalizante de nível médio era de 
744.690 (45,2\% em escolas públicas), o que correspondia a apenas $8,4 \%$ do total dos estudantes do ensino médio (INEP, 2007a).

No Brasil, como vimos, grande parte dos ingressantes no ensino médio, especialmente nas escolas públicas, não chega ao seu final, portanto, acaba sem nenhuma profissão. E dos que o concluem, mas não vão para a universidade, muitos também não têm uma profissão definida, já que a oferta de formação profissionalizante é muito limitada e ainda predominantemente concentrada na rede privada.

Uma diferença fundamental entre o Brasil e a Espanha encontra-se no plano político: lá o sistema representativo é bipartidário e aqui é pluripartidário. E isso, como vimos, tem conseqüências importantes no campo educacional.

Na Espanha, na era democrática pós-Constituição de 1978, dois partidos tem se revezado no poder: o PSOE e o PP. Essa polarização política, com grupos de interesses antagônicos claramente definidos em torno de cada um deles, explica a sucessão de reforma educacionais no país. Como vimos, o que um partido fazia, o outro modificava assim que chegava ao poder; o primeiro, por sua vez, assim que retornava, refazia o desfeito. Evidentemente não devem ser desprezadas às injunções externas - as demandas da sociedade do conhecimento, da globalização, da revolução técnico-científica e o papel normatizador da União Européia e da OCDE. Aliás, ambos os partidos lançam mão dessas injunções para justificar as reformas, muitas vezes, utilizando-as como cortina de fumaça para esconder seus interesses político-ideológicos e econômicos mais imediatos.

Além disso, de modo geral, as leis educacionais elaboradas na Espanha são mais detalhistas em comparação com as brasileiras, especialmente com a LDB 9394/96, e buscavam normatizar todos os aspectos das reformas. De modo que, lá as mudanças ficavam mais em evidência, instigando mais o debate e a tomada de posição a favor ou contra. Não deve ser desprezada também a força da Igreja Católica espanhola na defesa de seus valores e especialmente de seus interesses em torno da escola privada.

Isso explica uma característica do sistema de ensino espanhol que não existe aqui no sistema brasileiro: as escolas privadas concertadas. No Brasil, há 
uma "dupla rede" de ensino: as escolas públicas e as privadas. Na da Espanha há uma triple red: as escolas públicas, as escolas privadas e as escolas privadas concertadas. Tanto lá como cá há uma predominância de alunos nas escolas públicas, mas aqui o percentual dos que estudam nas escolas dos governos das três esferas de poder é bem maior do que lá, o que poderia ser um bom indicador, não fosse a má qualidade do ensino oferecido.

No Brasil, desde a abertura política implantou-se um sistema político pluripartidário, não havendo uma polaridade nitidamente delimitada, como na Espanha, já que os partidos estavam sendo construídos, as posições políticoideológicas se definindo e se consolidando, assim as alianças políticas eram temporárias e mutantes. Neste contexto de multipolarização, de indefinição, o "partido ideológico" (SAVIANI, 2006) mais articulado, que melhor defendeu seus interesses no Congresso foi o dos empresários da Educação e isso se refletiu na LDB 9394/96, uma lei "minimalista".

Apesar do Brasil sofrer praticamente as mesmas injunções externas aqui também se lançou mão da necessidade de se adaptar às mudanças tecnológicas e à sociedade do conhecimento para justificar as reformas -, os partidos políticos que estavam no poder quando da elaboração da LDB 9394/96 criaram, como vimos, uma lei enxuta, de modo que as reformas especialmente no campo curricular corriam por fora, longe dos holofotes e da pressão popular. Isso redundou em menos leis reformistas por aqui: só tivemos a LDB 9394/96 após a abertura política e as DCN e os PCN no campo curricular. Enquanto isso na Espanha houve várias leis, para o desânimo dos professores e demais envolvidos com o sistema educativo, como ilustra a figura 3 que mostra uma capa da revista Educación y Gestión da época em estava para ser aprovada a LOE:

Figura 3. Capa da revista Educación y Gestión 


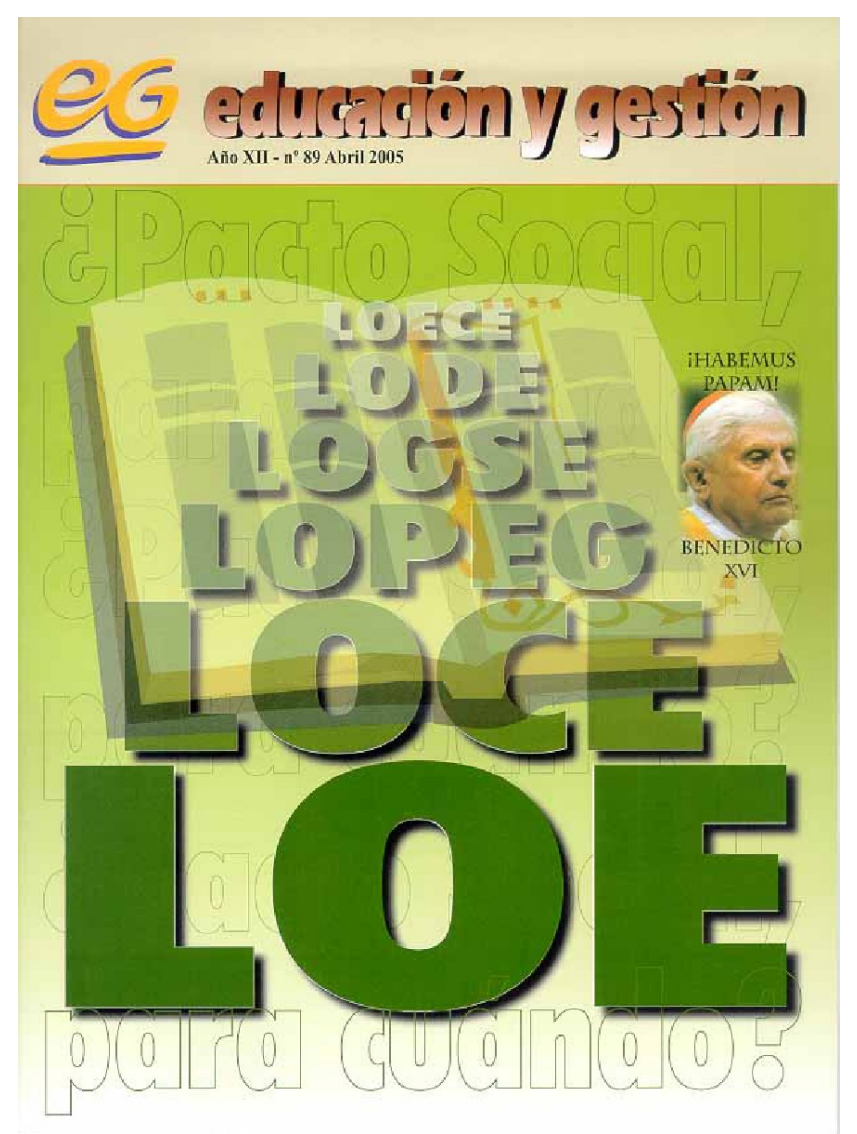

Fonte: Educación y Gestión. Madrid, año XII, n. 89, capa, abr. 2005.

Não quero dizer com isto, entretanto, que estejamos em situação melhor e que não haja desânimo entre os professores brasileiros, haja vista o estado de ânimo dos professores paulistas frente à nova reforma curricular (SÃO PAULO, 2008), lançada de forma pouco democrática pela Secretaria de Educação. Como o ensino médio é de responsabilidade do estados, esses entes da federação podem definir o currículo de forma articulada com os PCNEM e OCEM.

Tanto na Espanha como no Brasil as leis educacionais expressam convergências e divergências existentes nas respectivas sociedades. Tanto lá como cá, afloram nas leis conflitos de interesse econômicos entre o público e o privado, disputas ideológicas, político-partidárias, enfim, diferentes visões de mundo. Isso evidencia que de fato as reformas educacionais são um campo de enfrentamentos políticos, econômicos, ideológicos e teóricometodológicos. Estes últimos se manifestando especialmente em sua 
modalidade curricular, como veremos na comparação da Parte III deste trabalho. 


\section{Parte III}

\section{A reforma curricular no Brasil e na Espanha: Geografia}




\section{A Geografia no ensino médio brasileiro}

Para compreender a situação da Geografia no atual ensino médio brasileiro, é necessário estudar as propostas curriculares que se desdobraram da LDB 9394/96: os Parâmetros Curriculares Nacionais do Ensino Médio (PCNEM), os PCN + Ensino Médio: Orientações Educacionais Complementares aos Parâmetros Curriculares Nacionais e as mais recentes Orientações Curriculares para o Ensino Médio (OCEM). Entretanto, é importante uma breve retomada da situação da Geografia no ensino de segundo grau, sob a LDB anterior, a 5692/71, para contextualizar as mudanças ocorridas mais recentemente.

\section{Antecedentes: a Geografia no currículo do segundo grau}

Com a aprovação da LDB 5692/71, a Geografia perdeu autonomia no ensino de $1^{\circ}$ grau e foi diluída na disciplina Estudos Sociais, juntamente com História e Educação Moral e Cívica. No currículo do $2^{\circ} \mathrm{grau}$, a disciplina sobreviveu ao lado de História e Organização Social e Política do Brasil (OSPB). Como já foi mencionado, sob o regime militar-civil essas disciplinas cumpriam no currículo o papel de contribuir para a consolidação da "integração nacional" e fortalecer os valores "patrióticos" e "morais" do povo.

A Geografia que se ensinava então restringia-se à descrição da natureza, em primeiro lugar, e depois do homem e da economia. Inseria-se no paradigma da Geografia Tradicional e cumpria no currículo um papel já denunciado por Lacoste (1988) em seu livro A Geografia - isso serve, em primeiro lugar, para fazer a guerra. Publicado inicialmente na França em 1976, denunciava uma realidade que também era verdadeira para o Brasil. Nesse livro, Yves Lacoste afirmava que há duas Geografias: a dos "Estados Maiores" e a dos "professores". A primeira serve aos interesses do Estado e do capital; a segunda, praticada nos livros didáticos e nas 
salas de aula, cumpre um papel ideológico: o de mascarar o papel estratégico da Geografia - a geopolítica - e seu real interesse para os Estados Maiores. Nesse sentido, o desvendamento do espaço geográfico deveria ser de interesse apenas do Estado e do capital, não do cidadão comum. E como se faz para que o cidadão comum não tenha interesse pela Geografia, pela compreensão do espaço geográfico? Tornando-a uma disciplina mnemônica e corográfica, entediante e sem nenhum sentido. Assim era o ensino de Geografia no contexto da vigência da LDB $5692 / 71$. Era a época do famoso "decoreba", cujo exemplo emblemático consistia em obrigar os alunos a decorar todos os afluentes das margens esquerda e direita do rio Amazonas. Mas não era só isso, os estudantes também eram obrigados a decorar as capitais dos Estados brasileiros e dos países do mundo, assim como os picos mais altos, os rios mais extensos e uma série de outros dados que não viam nenhum sentido em aprender. Isso marcou gerações de estudantes e fez que, durante muito tempo, a Geografia pagasse um preço muito alto. Até hoje muita gente pensa que o ensino da disciplina ainda se restringe a isso. Veja o que escreveu Clóvis Rossi, jornalista e articulista do jornal Folha de S.Paulo, durante a guerra do Afeganistão:

Era uma vez um tempo em que tudo o que os mortais comuns aprendíamos sobre
Afeganistão era decorar "Afeganistão, capital Cabul”, nas aulas de Geografia.
Por isso, só posso festejar o porre de Afeganistão que a mídia oferece ao público. Já
sabemos que, além de Cabul, há Candahar, Jalalabad, Herat, Mazar-e-Sharif, que há
pashtus, usbeques, tadjiques, um rei deposto, uma Aliança do Norte, o diabo.
Nada contra. Muita gente pode até achar que são informações irrelevantes, mas é
sempre melhor alguma informação, ainda que irrelevante, do que nenhuma
informação. (ROSSI, 2001, p. A2).

Para os que fizeram primeiro e segundo graus, e, mesmo antes, para os que fizeram primário, ginásio e colégio, como é o caso de Rossi, essa foi a concepção que ficou da Geografia escolar.

Ao que parece, além de a Geografia servir para fazer a guerra, pode também ser aprendida por meio de um conflito bélico. Luis Fernando Verissimo, escritor e articulista do jornal O Estado de S. Paulo, comentando a mesma guerra do Afeganistão, afirmou: "É do Mário Quintana a definição de guerra como um meio 
prático de se aprender Geografia. Quem sabia, antes disso tudo começar, que havia tantos países terminados em 'ão'? O Bush certamente não." (VERÍSSIMO, 2001).

Entretanto, há que se deixar claro a diferença entre aprender, como compreensão do mundo, e simplesmente ter informações sobre o mundo. Discordando de Rossi, penso que informação irrelevante (ou excesso dela) é o mesmo que nenhuma informação. Além de não contribuir para o processo de aprendizagem, o excesso de informação nos expõe ao risco de perda da memória, nos deixa aprisionados num eterno presente, sem passado nem futuro. Concordo com o semiólogo e escritor Umberto Eco: "Esse é um de nossos problemas contemporâneos. A abundância de informação irrelevante, a dificuldade em selecioná-la e a perda de memória do passado - e não digo nem sequer da memória histórica." (ECO, 2008). Este é o grande desafio com o qual cada vez mais deparam os professores em geral e os de Geografia em particular diante do enorme crescimento das informações disponíveis: selecionar as que são relevantes e transformá-las em conhecimentos significativos que permitam aos alunos compreender o mundo em que vivemos. Como já disse Marina (1995), compreender é apreender o novo com o já conhecido, e só assim o conhecimento será significativo.

Um ensino de Geografia que obrigava os alunos a decorar mecanicamente um monte de informações claramente não lhes permitia compreender o mundo em que viviam. Só servia para fazer com que tivessem aversão à disciplina, que, assim, cumpria seu papel ideológico no currículo da escola básica, como denunciado por Lacoste (1988).

Essa situação da Geografia se estende ainda pelos anos 1980, quando a renovação crítica que vinha sendo gestada desde a década anterior começou a aportar na educação de primeiro e segundo graus. Isso se deve, por um lado, à entrada no mercado de trabalho de professores formados de acordo com o novo paradigma e, por outro, à produção de propostas curriculares inovadoras em substituição aos antigos Guias Curriculares. Entre as propostas inovadoras, vale mencionar a da Coordenadoria de Estudos e Normas Pedagógicas (CENP) da 
Secretária da Educação do Estado de São Paulo (SÃO PAULO, 1988) ${ }^{88}$, pelo pioneirismo inovador, por mais que se possa discordar de seu enfoque teóricometodológico, fundamentado numa determinada leitura do marxismo, e pela influência que teve em propostas de outros Estados da Federação. A produção de livros didáticos orientados pela Geografia crítica também contribui para a inovação no ensino da disciplina.

Outro livro que desempenhou importante papel no processo de renovação crítica da Geografia acadêmica no Brasil foi Por uma Geografia nova, publicado por Milton Santos, em 1978. Aliás, a vasta obra do internacionalmente reconhecido geógrafo brasileiro ${ }^{89}$, especialmente $A$ natureza do espaço, de 1996, seu livro mais importante, teve influência decisiva nas novas propostas curriculares e nos novos livros didáticos produzidos no país.

De fato, os Parâmetros Curriculares Nacionais do Ensino Médio (PCNEM) de Geografia que foram elaborados em seguida, especialmente sua seleção de conceitos-chave da disciplina, foram visivelmente inspirados na teoria de Milton Santos, como vou procurar demonstrar a seguir.

Apesar de a renovação crítica da Geografia completar três décadas e muito ter sido feito no sentido de renovar seu ensino na escola básica, ainda não chegamos a um consenso, ou melhor, ainda não encontramos caminhos consistentes, mesmo que no dissenso. Como aponta Pontuschka (1999a, p. 112):

Estamos terminando o século XX e continuamos a nos fazer perguntas antigas sobre 0 ensino-aprendizagem da Geografia. Que conteúdos selecionar? Que método utilizar? Que linguagens priorizar? Como sensibilizar os alunos para a importância do conhecimento da Geografia para a sua vida em suas múltiplas dimensões?

88 Até a publicação dos Parâmetros Curriculares Nacionais, a elaboração do currículo era responsabilidade dos estados. A "proposta da CENP", como ficou conhecida, foi elaborada durante o governo André Franco Montoro (1983-1987), portanto no início do processo de abertura política. A edição definitiva (4ª versão) foi publicada em 1988, no Governo Orestes Quércia (1987-1991). A proposta de Geografia foi elaborada por uma equipe composta de doze professores universitários (oito da USP, dois da UNESP, um da UNICAMP e um da PUC-RJ) mais oito professores membros da equipe técnica da CENP. Esse trabalho foi coordenado pelo professor Gil Sodero de Toledo, com a assessoria do professor Ariovaldo Umbelino de Oliveira, ambos do Departamento de Geografia da FFLCH-USP. Sua elaboração foi um processo democrático, e desde que saiu a $1^{\text {a }}$ versão, em 1986, foi exaustivamente debatida com os professores nas Delegacias (hoje Diretorias) Regionais de Ensino, em encontros da APEOESP e da AGB.

89 Milton Santos nasceu em Brotas de Macaúbas (BA), em 1926, e faleceu em São Paulo (SP), em 2001. Publicou mais de 40 livros e dezenas de artigos científicos. Era professor do Departamento de Geografia da FFLCH-USP. Em 1994 ganhou o prêmio Vautrin Lud na França, conhecido como o "Nobel” da Geografia. 
Atualizando seu texto, já estamos começando o século XXI, mas as dúvidas e as contradições permanecem. Vejamos algumas evidências disso.

\title{
O currículo do ensino médio
}

Como já apontado, a LDB 9394/96 foi uma lei minimalista. Deixou, assim, para a legislação complementar o papel de implementar a reforma curricular do ensino fundamental e médio. Inicialmente, o responsável por isso foram os Parâmetros Curriculares Nacionais (PCN). Os Parâmetros Curriculares Nacionais de Ensino Médio (PCNEM) foram lançados em 1999. Esse documento deu um tratamento de área aos conteúdos a serem ensinados no ensino médio. A equipe multidisciplinar encarregada de sua elaboração estabeleceu três grandes áreas: Linguagens, Códigos e suas Tecnologias; Ciências da Natureza, Matemática e suas Tecnologias; Ciências Humanas e suas Tecnologias. É nessa última que se insere a Geografia $^{90}$, ao lado de História, Filosofia e Ciências Sociais (Sociologia, Antropologia e Política). Essa nova organização é uma tentativa de estimular uma abordagem interdisciplinar e contextualizada. De acordo com o documento:

\begin{abstract}
A reforma curricular do Ensino Médio estabelece a divisão do conhecimento escolar em áreas, uma vez que entende os conhecimentos cada vez mais imbricados aos conhecedores, seja no campo técnico-científico, seja no âmbito da vida social. A organização em três áreas - Linguagens, Códigos e suas Tecnologias, Ciências da Natureza, Matemática e suas Tecnologias e Ciências Humanas e suas Tecnologias tem como base a reunião daqueles conhecimentos que compartilham objetivos de estudo e, portanto, mais facilmente se comunicam, criando as condições para que a prática escolar se desenvolva numa perspectiva de interdisciplinaridade. (BRASIL, 2002a, p. 32).
\end{abstract}

Em outra passagem reafirma essa intenção:

A tendência atual, em todos os níveis de ensino, é analisar a realidade segmentada, sem desenvolver a compreensão dos múltiplos conhecimentos que se interpenetram e conformam determinados fenômenos. Para essa visão segmentada contribui o

90 Entre os seis consultores responsáveis pela área de Ciências Humanas do PCNEM, havia representantes de Geografia, História, Filosofia, Ciências Sociais e Educação. A representante da Geografia foi a professora Catia Antonia da Silva, do Departamento de Geografia do Centro de Educação e Humanidades da Universidade do Estado do Rio de Janeiro (UERJ). 
enfoque meramente disciplinar que, na nossa proposta de reforma curricular, pretendemos superado pela perspectiva interdisciplinar e pela contextualização dos conhecimentos. (BRASIL, 2002a, p. 34).

Entretanto, uma coisa é o currículo no papel, outra bem diferente é o currículo na prática escolar do dia-a-dia. A realidade tem uma dinâmica que, muitas vezes, impõe resistências às intenções dos consultores, por melhores que estas sejam. Assim, uma coisa é propor a interdisciplinaridade no documento, outra é viabilizá-la na prática escolar.

\section{CONHECIMENTO INTERDISCIPLINAR OU DISCIPLINAR? E AS COMPETÊNCIAS?}

\section{Os Parâmetros Curriculares Nacionais do Ensino Médio (PCNEM)} propõem um ensino interdisciplinar, como fica evidente pela leitura dos trechos acima; no entanto, toda a cultura vigente nas escolas está ancorada em um currículo disciplinar. As aulas são divididas por disciplinas, os livros didáticos são organizados por disciplinas, a longa tradição cartesiano-positivista da formação acadêmica dos professores é disciplinar e a própria organização do espaço escolar é voltada ao ensino disciplinar. Além disso, os próprios PCNEM, apesar de defenderem a interdisciplinaridade, na versão complementar publicada em 2002, chamada de $\mathrm{PCN}+$, propuseram uma organização curricular em eixos temáticos essencialmente disciplinares, embora fazendo a seguinte ressalva:

[...] não devem ser entendidas [as sugestões temáticas] como listas de tópicos que possam ser tomadas por um currículo mínimo, porque é simplesmente uma proposta, nem obrigatória nem única, de uma visão ampla do trabalho em cada disciplina. (BRASIL, 2002b, p. 14).

Essa incoerência é apontada pelos autores da versão preliminar das Orientações Curriculares para o Ensino Médio (OCEM) quando analisam a proposta dos PCNEM para a Geografia, mas isso também ocorre nas outras disciplinas:

[...] a forma de organização dos conteúdos, como está apresentada nas páginas 66 a 68 dos $\mathrm{PCN}+$, em análise, não contém, em si mesma, a proposta de interdisciplinaridade defendida nos parâmetros uma vez que os conteúdos continuam a ser apresentados por disciplinas. Além disso, o livro didático, importante instrumento 
de trabalho dos professores desse nível de ensino, também são produzidos e utilizados em componentes curriculares específicos. (BRASIL, 2004a, p. 325).

Na versão final das OCEM (BRASIL, 2006) continuam constando os eixos temáticos, entretanto, como já não são os mesmos autores que elaboraram o PCN + (pelo menos os de Geografia), mudaram os temas. Além disso, esses novos eixos temáticos são mais genéricos que aqueles, dando ao professor maior flexibilidade para definir os assuntos a serem tratados na área.

Diante dessa flexibilidade e dessas incoerências, na prática o currículo real do ensino médio continua sendo definido pelos programas dos exames vestibulares mais concorridos, pelos livros didáticos e pelas apostilas dos chamados "sistemas de ensino".

Em nível regional, o currículo é definido pela instituição de ensino superior mais concorrida da cidade, estado ou região, sempre uma universidade pública federal ou estadual (ver anexo A). No estado de São Paulo, por exemplo, a instituição de ensino superior mais concorrida é a Universidade de São Paulo (estadual), cujo exame vestibular é organizado pela FUVEST. Essa prova é referência para a definição dos conteúdos ensinados nos colégios privados de ensino médio e nos cursos pré-vestibular. O poder conformador exercido pelo vestibular da FUVEST sobre o currículo extrapola os limites do estado de São Paulo, já que é o exame mais concorrido do país e recebe muitos candidatos de outros estados. Os vestibulares em geral, e não apenas o da FUVEST, influenciam mais fortemente o currículo das escolas de ensino médio privadas. Quase todos os seus alunos têm como meta ingressar em um curso superior e dispõem de mais suporte socioeconômico e preparo intelectual para atingi-la. Como vimos, a maioria dos candidatos que prestaram o vestibular da FUVEST e especialmente dos que o superaram e ingressaram na USP, é oriunda de escolas privadas (rever tabelas 8 e 9).

O próprio MEC constata a influência do vestibular na definição do currículo do ensino médio. Ao propor que a condução autônoma do projeto de vida das pessoas reclama uma escola média de sólida formação geral, ressalva: "Mas o significado de educação geral no nível médio, segundo o espírito da LDB, nada tem 
a ver com o ensino enciclopedista e academicista dos currículos de ensino médio tradicionais reféns do vestibular." (BRASIL, 2002a, p. 85-86). Se o próprio MEC constata essa situação, mas se mostra impotente para mudá-la, que dirá os estudantes, que não podem cursar esse ensino médio que franquia o acesso à universidade, em geral restrito às melhores escolas privadas, ou fazer um curso prévestibular. Vem daí a contradição: a maioria dos estudantes do ensino médio público não consegue passar no exame vestibular das universidades públicas. Devemos lembrar outra contradição: quem elabora esses exames são docentes das próprias universidades, onde atuam educadores envolvidos com a mudança curricular, muitos deles críticos do exame vestibular.

Em escala nacional, na prática, são os livros didáticos que historicamente vêm definindo o currículo do ensino médio, como constato pela minha própria prática e por observações em viagens pelo Brasil. Os livros educativos são os principais responsáveis pela implementação do currículo nas escolas ${ }^{91}$, com toda a pluralidade teórico-metodológica que os caracterizam e com toda a subjetividade de seus autores na interpretação dos PCNEM; ao lado, claro, dos professores que os utilizam, interpretam e recriam seus conteúdos. Os livros são complementados pelos professores, e em geral articulados com conteúdo de caráter regional ou local, para dar conta do programa do vestibular da universidade pública mais concorrida da cidade, do estado ou da região. Um livro didático que é distribuído no país inteiro nunca dá conta das especificidades locais e regionais.

Concorrendo com os livros didáticos, as apostilas produzidas pelos chamados "sistemas de ensino", como Anglo (São Paulo-SP), Objetivo (São PauloSP), Positivo (Curitiba-PR) e COC (Ribeiro Preto-SP), têm aumentado o papel conformador do currículo. Originárias de cursos pré-vestibulares, durante muito tempo estiveram restritas às escolas privadas de ensino fundamental e médio; ultimamente, entretanto, os "sistemas de ensino" têm sido comprados por algumas prefeituras, que com isso abrem mão dos livros fornecidos pelo MEC por meio do Programa Nacional do Livro Didático (PNLD). Os livros educativos são certificados por uma equipe de avaliadores composta por professores de universidades públicas

91 Como veremos no capítulo a seguir, isso também ocorre na Espanha, como afirma Gimeno Sacristán (2000). 
contratados pelo MEC, e os que são reprovados não entram no guia que serve de referência para a escolha do professor da escola básica. Já as apostilas, não passam por nenhum tipo de avaliação. Do ponto de vista pedagógico, devido à sua rigidez (muitas têm aulas numeradas), as apostilas impossibilitam o trabalho de interpretação e recriação do currículo manifesto por parte do professor, transformando-o em um mero reprodutor de um conhecimento imposto. Além disso, no PNLD, quem escolhe o livro didático a ser utilizado em sala de aula é o professor; no caso as apostilas, quem escolhe, em geral, é o Secretário da Educação do Município.

Nos últimos anos, o Exame Nacional do Ensino Médio (ENEM), apesar de seu caráter voluntário, tem ampliado seu papel de agente conformador do currículo da escola média. O ENEM é uma prova aplicada pelo INEP em todo o território nacional e podem prestá-la os egressos do ensino médio, independentemente de quando se formaram, e os que acabaram de concluir esse nível de ensino. O exame foi instituído pela Portaria Ministerial n. 438, de 28 de maio de 1998, com os seguintes objetivos, como consta de seu artigo $1^{\circ}$ :

I - conferir ao cidadão parâmetro para auto-avaliação, com vistas à continuidade de sua formação e à sua inserção no mercado de trabalho;

II - criar referência nacional para os egressos de qualquer das modalidades do ensino médio;

III - fornecer subsídios às diferentes modalidades de acesso à educação superior;

IV - constituir-se em modalidade de acesso a cursos profissionalizantes pós-médio. (BRASIL, 1998).

O papel conformador do currículo nacional fica mais evidente no item II do artigo $1^{\circ} \mathrm{e}$ especialmente no item III. De fato, diversas universidades têm utilizado os resultados do ENEM, de forma alternativa ou complementar aos seus respectivos vestibulares, para selecionar os ingressantes em seus cursos. De acordo com o INEP, mais de 600 instituições de ensino superior já utilizam, de forma substitutiva ou complementar, os resultados do ENEM em seus processos seletivos. Esse fato vem contribuindo para o crescente aumento das inscrições no exame: em 2006 houve cerca de 3,7 milhões de inscritos, contra apenas 157 mil em $1998^{92}$.

92 ENEM: histórico. INEP. Disponível em: <www.enem.inep.gov.br>. Acesso em: 30 set. 2008. 
O documento Exame Nacional do Ensino Médio (ENEM): fundamentação teórico-metodológica ${ }^{93}$, depois de reconhecer que está crescendo o papel do ENEM como instrumento de seleção ao ensino superior, explicita seu propósito conformador do currículo de ensino médio:

O Enem tem, ainda, papel fundamental na implementação da Reforma do Ensino Médio, ao apresentar, nos itens da prova, os conceitos de situação-problema, interdisciplinaridade e contextualização, que são, ainda, mal compreendidos e pouco habituais na comunidade escolar. A prova do Enem, ao entrar na escola, possibilita a discussão entre professores e alunos dessa nova concepção de ensino preconizada pela LDB, pelos Parâmetros Curriculares Nacionais e pela Reforma do Ensino Médio, norteadores da concepção do exame. (INEP, 2005, p. 8).

Entretanto, deve ser lembrado que o papel conformador do ENEM sobre o currículo não se dá sobre a modalidade conceitual do conhecimento, já que não apresenta nenhuma proposta de conteúdos, mas sobre a procedimental. $\mathrm{O}$ exame está assentado sobre cinco competências voltadas para o domínio de linguagens, a compreensão de fenômenos, o enfrentamento de situações-problema, a construção de argumentos e a elaboração de propostas, como mostra mais detalhadamente o trecho a seguir. Essas competências se articulam com 21 habilidades, constituindo a matriz que serve de orientação para a elaboração das 63 questões de caráter interdisciplinar que compõem a prova.

\section{ENEM - COMPETÊNCIAS}

I. Dominar a norma culta da Língua Portuguesa e fazer uso das linguagens matemática, artística e científica.

II. Construir e aplicar conceitos das várias áreas do conhecimento para a compreensão de fenômenos naturais, de processos histórico-geográficos, da produção tecnológica e das manifestações artísticas.

III. Selecionar, organizar, relacionar, interpretar dados e informações representados de diferentes formas, para tomar decisões e enfrentar situações-problema.

IV. Relacionar informações, representadas em diferentes formas, e conhecimentos disponíveis em situações concretas, para construir argumentação consistente.

V. Recorrer aos conhecimentos desenvolvidos na escola para elaboração de propostas de intervenção solidária na realidade, respeitando os valores humanos e considerando a diversidade sociocultural. (INEP, 1998, p. 6)

93 Esse documento, publicado em 2005, foi elaborado por uma equipe multidisciplinar composta de 20 profissionais para, segundo a apresentação de Ataíde Alves, Diretor de Avaliação de Certificação de Competência do INEP, "contribuir para uma melhor compreensão dos eixos cognitivos que o estruturam e, mais do que isso, na medida em que professores, educadores, pesquisadores e o público em geral a eles tenham acesso, possam discutir e melhor refletir sobre o significado de seus resultados ao longo desses oito anos de avaliação." (INEP, 2005, p. 8-9). 
Assim, o currículo manifesto do ensino médio, o que está no papel, é apenas uma intenção; para ser colocado em prática, há muitas mediações - do exame vestibular" ${ }^{94}$, do livro didático, das apostilas, do ENEM, do professor e das condições da própria escola (situação socioeconômica dos estudantes; grau de formação, de envolvimento e de assiduidade dos professores; nível de participação da comunidade) - até transformar-se em currículo real.

Devemos considerar ainda que, em qualquer sistema de ensino, há uma "cultura escolar" (VIÑAO, 2003) ou uma "gramática escolar"95 (TYACK; CUBAN, 1975 apud VIÑAO, 2003) - hábitos e costumes consolidados ao longo do tempo sobre modos de ensinar, seleção de conteúdos, formas de avaliação etc. - que é difícil modificar. Há também o fenômeno do isomorfismo: o professor tende a ensinar do mesmo modo que aprendeu, e a formação universitária dos professores ainda é fragmentada, calcada no paradigma cartesiano-positivista.

Pelo trecho retirado da fundamentação teórico-metodológica do ENEM, percebe-se que o MEC pretende que o exame desempenhe o papel de agente catalisador da mudança em direção a essa "nova concepção de ensino". Seus idealizadores contam que o exame induza a substituição de um ensino que transmite conhecimento disciplinar, conteudista e descontextualizado por um ensino que desenvolva um conhecimento interdisciplinar, contextualizado e ancorado em competências e habilidades. Entretanto, para a implantação de um ensino interdisciplinar seria necessário primeiro criar as condições reais para que isso ocorra; além disso, é fundamental que os professores se sintam co-autores e acreditem nessa proposta. A efetivação de uma proposta interdisciplinar, ao contrário do que em geral se pensa, exige professores mais bem preparados, com profundo conhecimento em seus respectivos campos disciplinares. A interdisciplinaridade é um processo coletivo em que cada especialista, de cada

94 No caso de Espanha, como veremos no próximo capítulo, a mediação correlata ao vestibular brasileiro cabe às "Pruebas de acceso a la Universidade" (PAU).

95 "Viñao (2003, p. 38-39) define "gramática de la escuela" como "ese conjunto de tradiciones y regularidades institucionales sedimentadas a lo largo del tiempo, transmitidas de generación en generación por los profesores, de modos de hacer y de pensar aprendidos a través de la experiencia docente, de reglas de juego y supuestos compartidos, no puestos en entredicho, que son los que permiten a los profesores organizar la actividad académica, llevar la clase y, dada la sucesión de reformas ininterrumpidas que se plantean desde el poder político y administrativo, adaptarlas, transformándolas, a las exigencias que se derivan de dicha 'gramática'.". 
campo disciplinar, dá sua contribuição para a compreensão de um determinado fenômeno. Interdisciplinaridade não se faz individualmente, por um professor isolado. Até porque, na era informacional, diante da enorme ampliação das informações e dos conhecimentos disponíveis, a tendência é aumentar ainda mais o processo de especialização e de surgimento de novos campos disciplinares. É impossível que um professor individualmente dê conta de compreender uma realidade cada vez mais complexa. Ou seja, a especialização não é apenas uma nociva herança cartesiano-positivista, é uma crescente exigência da própria era informacional, da sociedade do conhecimento.

Um interessante exemplo de interdisciplinaridade vem da própria teoria crítica, que nasceu em um ambiente marcado pelo "materialismo interdisciplinar". Como recorda Nobre (2008, p. 36): "Horkheimer criou no Instituto de Pesquisa Social um ambiente de trabalho interdisciplinar, em que especialistas de diferentes áreas colaboravam com a perspectiva comum da orientação para a emancipação que caracteriza a Teoria Crítica.". Ou seja, especialistas de diversos campos disciplinares, como a Economia, a Filosofia, a Sociologia, a Psicologia, entre outros, trabalhavam em conjunto não apenas para compreender a sociedade capitalista naquele momento histórico, mas também para tentar transformá-la, já que eram orientados pela perspectiva emancipatória. Isso aponta para uma mudança importante a ser implementada na educação escolar: o professor em geral trabalha isoladamente, no âmbito de sua disciplina; a interdisciplinaridade exige trabalho em equipe, senso de coletividade. Não sendo tarefa exclusiva dos professores, essa mudança não ocorrerá sem o decidido apoio de todo o sistema educativo.

\section{E O PAPEL DOS PROFESSORES?}

Como mencionei na introdução, segundo o Ministério da Educação, a proposta dos PCNEM não foi assimilada pelo sistema de ensino. Por isso, em 2004 foram convocados diversos especialistas para a elaboração de outra proposta: as Orientações Curriculares do Ensino Médio. Esse documento serviu de base para o 
debate sobre os rumos do novo ensino médio e para a proposta definitiva, publicada em 2006.

A proposta dos PCNEM "não se concretizou", para usar as palavras do então Secretário de Educação Básica, Francisco das Chagas Fernandes, na apresentação da proposta preliminar das Orientações Curriculares:

[...] é necessário considerar que tal proposta não se concretizou com a sua implementação por não ter conseguido, nas diferentes instâncias do Ensino Médio, aprofundar análise consistente que permitisse esclarecer e orientar as escolas, bem como promover o estudo do documento e discutir as possibilidades didáticopedagógicas, por ela apresentadas, junto ao professor na execução da sua prática docente. (BRASIL, 2004a, p. 6).

O Secretário de Educação Básica faz um diagnóstico correto do problema, mas não encontra uma boa explicação para suas causas, e conseqüentemente não aponta a melhor solução. A proposta dos PCNEM, entre outros fatores, não se concretizou porque a maioria dos professores não se sentiu co-autora dela e protagonista do processo de sua construção. Esse documento, concebido da perspectiva técnica do currículo, foi pensado e produzido nas instâncias superiores do sistema de ensino e chegou pronto para os professores. Além disso, apresenta incompatibilidades estruturais e incoerências, como buscarei indicar a seguir, que dificultam sua implementação.

Quanto ao protagonismo dos professores é interessante ler um trecho muito instrutivo das Diretrizes Curriculares Nacionais do Ensino Médio (parecer CEB 15/98), documento que orientou a elaboração dos PCNEM:

As instâncias centrais dos sistemas de ensino precisam entender que existe um espaço de decisão privativo da escola e do professor em sala de aula que resiste aos controles formais. A legitimidade e a eficácia de qualquer intervenção externa nesse espaço privativo dependem de convencer a todos do seu valor para a ação pedagógica. Vale dizer que a proposta pedagógica não existe sem um forte protagonismo do professor e sem que este dela se aproprie (BRASIL, 2002a, p. 83, grifo do autor).

Além de o verbo "convencer" soar um tanto impositivo, porque em geral implica uma ação externa, até parece que esse documento não foi elaborado dentro da instância central do sistema de ensino - leia-se MEC, no Brasil. E, mais, o parecer da Câmara de Ensino Básico (CEB) serviu de orientação ao documento que 
"não se concretizou". Talvez tenha faltado, em vez de "convencer" os professores do valor da proposta, "convidá-los" a participar do processo, para que eles próprios "se convencessem", em vez de "serem convencidos", da importância dos PCNEM para a ação pedagógica. E, mais do que isso, faltou garantir-lhes as condições necessárias para trabalhar com base nesse documento, assegurando assim seu protagonismo no processo.

Entretanto, o que é mais preocupante são as incoerências no interior dos próprios documentos elaborados com o intuito de orientar a mudança. Não é de estranhar que eles não sejam assimilados nas escolas. Aliás, é sintomático o fato de existirem tantos e tão extensos documentos. O PCNEM, elaborado em 1999 (BRASIL, 1999) $^{96}$, como vimos, "não se concretizou". Com isso, o MEC elaborou o PCN + (BRASIL, 2002b), que no fim das contas aprofundou ou explicitou as contradições do documento anterior. Esse fato exigiu a elaboração de uma nova proposta - as Orientações Curriculares do Ensino Médio (BRASIL, 2004a) - a ser debatida a fim de servir de base para: a produção de um novo documento! Em seguida foram publicadas as Orientações Curriculares Nacionais para o Ensino Médio (BRASIL, 2006), em três volumes - um para cada grande área do conhecimento. Esse novo documento pretende fazer a:

[...] retomada da discussão dos Parâmetros Curriculares Nacionais do Ensino Médio, não só no sentido de aprofundar a compreensão sobre pontos que mereciam esclarecimentos, como também de apontar e desenvolver indicativos que pudessem oferecer alternativas didático-pedagógicas para a organização do trabalho pedagógico, a fim de atender às necessidades e às expectativas das escolas e dos professores na estruturação do currículo para o ensino médio. (BRASIL, 2006, p. 8).

Inevitavelmente isso nos faz lembrar um dito, cuja autoria é desconhecida, que todos já ouvimos em sala de professores e que, como qualquer dito popular, não está livre de preconceitos e estereótipos. Diz mais ou menos o seguinte: em uma sala de aula, se um, dois, três... uns poucos alunos vão mal, o problema é com eles, devem apresentar alguma dificuldade de aprendizagem; mas, se a classe inteira vai mal, o problema é com o professor, deve haver alguma falha em seu método de ensino.

96 Em 2002 foi publicada outra versão revisada do PCNEM (BRASIL, 2002a), na qual há pequenas mudanças, quase sempre de palavras, em relação a essa primeira. 
Pois bem, se os documentos não são compreendidos, exigindo novos textos, explicações e aprofundamentos na suposição de que os professores não entenderam; se as propostas não se concretizam, talvez haja algum problema com os documentos, com suas propostas. Segundo as OCEM:

O currículo é a expressão dinâmica do conceito que a escola e o sistema de ensino têm sobre o desenvolvimento dos seus alunos e que se propõe a realizar com e para eles. Portanto, qualquer orientação que se apresente não pode chegar à equipe docente como prescrição quanto ao trabalho a ser feito. (BRASIL, 2006, p. 9).

Talvez aí já esteja a resposta: "qualquer orientação que se apresente não pode chegar à equipe docente como prescrição quanto ao trabalho a ser feito". Esse é o problema: apesar do discurso, na prática os PCNEM e as OCEM são orientados por um interesse técnico e têm caráter prescritivo. Até no linguajar as OCEM têm um caráter tecnicista - falam, por exemplo, em "ensino eficaz" e "objetivos de aprendizagem" (BRASIL, 2006, p. 48) - e prescritivo - usam com freqüência o verbo dever $^{97}$-, como ilustra o trecho a seguir, que trata dos conhecimentos de Geografia:

A Geografia compõe o currículo do ensino fundamental e médio e deve preparar o aluno para: localizar, compreender e atuar no mundo complexo [...]

A partir dessas premissas, o professor deverá proporcionar práticas e reflexões que levem o aluno à compreensão da realidade.

Portanto, para que os objetivos sejam alcançados, o ensino de Geografia deve fundamentar-se em um corpo teórico-metodológico baseado nos conceitos de natureza, paisagem, espaço [...] (BRASIL, 2006, p. 43, grifo nosso).

Em outro trecho, o documento defende acertadamente a necessidade de o professor participar com os alunos do processo de construção de conceitos e saberes com base no conhecimento prévio deles. Logo em seguida argumenta que:

Nesse processo, é fundamental a participação do professor no debate teóricometodológico, o que the possibilita pensar e planejar a sua prática, quer seja individual, quer seja coletiva. Essa participação faz com que o professor tenha acesso ao material produzido pela comunidade científica da Geografia, o que Ihe permitirá discussões atualizadas que vão muito além da abordagem existente nos livros didáticos. (BRASIL, 2006, p. 47).

Aparentemente não há nenhum problema com essa proposta aos professores: de fato é importante que eles tenham acesso ao material produzido

97 O verbo “dever" apresenta diversas acepções, quase todas associadas à idéia de obrigação, quando não de submissão. 
pela comunidade científica, que não fiquem restritos aos livros didáticos e que participem do debate teórico-metodológico. Entretanto, parece que só há conhecimentos e saberes para os professores na comunidade científica, na qual se dá a produção e se concentra o debate teórico-metodológico, ou, talvez, no livro didático. Os autores do documento são docentes do ensino superior empenhados na boa formação de professores para a escola básica e seguramente têm sensibilidade para essa questão, mas, da forma que a situação foi colocada, o papel do professor como sujeito, como produtor de conhecimentos e saberes foi negligenciado. Nessa proposta, não há dialogicidade, não há ação comunicativa; novamente há prescrição, característica de um currículo orientado pelo interesse técnico.

Enquanto o professor não for, ou ao menos se sentir, verdadeiramente protagonista, co-partícipe, enfim, sujeito do processo, não há proposta reformista que se concretize. Sem contar que, como veremos a seguir, as propostas curriculares expressam a diversidade de correntes de pensamento existente no interior da "comunidade científica da Geografia", às vezes divergências teóricometodológicas. Isso é salutar, expressa a diversidade da disciplina, a existência do debate. Entretanto, se essas diferenças ou divergências não são discutidas, explicitadas, esmiuçadas, isso pode, ao invés de contribuir para o trabalho dos professores da escola básica, criar-Ihes grandes dificuldades.

\section{A Geografia nas propostas curriculares para o ensino médio}

\section{Os PCNEM e o eSPaÇo geográfico: conceito estruturante}

$\mathrm{Na}$ proposta curricular de Geografia dos Parâmetros Curriculares Nacionais do Ensino Médio (BRASIL, 1999, 2002a), o espaço geográfico foi tomado como conceito estruturante a partir do qual se derivaram outros conceitos-chave. Como já mencionado, essa proposta foi inspirada na teoria de Milton Santos, e a leitura do trecho a seguir deixa isso patente: 
Surge, pois, o objeto dos nossos estudos: o espaço geográfico. Definido por Milton Santos em sua vasta obra sobre o assunto, é o conjunto indissociável de sistemas de objetos (redes técnicas, prédios, ruas) e de sistemas de ações (organização do trabalho, produção, circulação, consumo de mercadorias, relações familiares e cotidianas), que procura revelar as práticas sociais dos diferentes grupos que nele produzem, lutam, sonham, vivem e fazem a vida caminhar. (BRASIL, 1999, p. 60; BRASIL, 2002a, p. 310, grifo do autor).

A fonte de inspiração teórica para os elaboradores dos PCNEM definirem a matriz conceitual da proposta curricular de Geografia encontra-se especialmente no livro A natureza do espaço, publicado em 1996, como se depreende da leitura do fragmento a seguir:

A partir da noção de espaço como um conjunto indissociável de sistemas de objetos e sistemas de ações podemos reconhecer suas categorias analíticas internas. Entre elas, estão a paisagem, a configuração territorial, a divisão territorial do trabalho, o espaço produzido ou produtivo, as rugosidades e as formas-conteúdo. Da mesma maneira, e com o mesmo ponto de partida, levanta-se a questão dos recortes espaciais, propondo debates de problemas como o da região e o do lugar; o das redes e das escalas. Paralelamente, impõem-se a realidade do meio com seus diversos conteúdos em artifício e a complementaridade entre uma tecnoesfera e uma psicoesfera. E do mesmo passo podemos propor a questão da racionalidade do espaço como conceito histórico atual e fruto, ao mesmo tempo, da emergência das redes e do processo de globalização. (SANTOS, 1996a, p. 19).

Com base nessas idéias, os autores da proposta curricular de Geografia definiram como conceitos-chave para o ensino da disciplina: espaço geográfico, paisagem, lugar, território, escala e globalização, redes e técnicas.

O espaço geográfico é o ponto de partida (ou o "conceito amplo", como aparece no quadro 10) do qual derivam os "conceitos específicos" de paisagem (uma das "categorias analíticas internas" segundo Milton Santos), lugar (um dos "recortes espaciais" com a região, embora este não apareça na lista do PCNEM), escalas e globalização. E não é possível discutir o espaço geográfico na era informacional, em tempos de globalização, sem lançar mão dos conceitos de redes e técnicas, que completam a lista. Chama a atenção o fato de que os autores optaram por não incluir o conceito de região entre os conceitos-chave da Geografia, mas incluem o de território, a que Santos (1996a) não deu tanta ênfase. Se bem que no livro $A$ natureza do espaço ele também não enfatiza muito o conceito de 
região, concentrando sua discussão sobre o espaço, a paisagem, o lugar, as redes e as técnicas.

Os PCN + Ensino Médio: Orientações Educacionais Complementares aos Parâmetros Curriculares Nacionais, mais conhecidos por PCN+, foram elaborados em 2002, por outra equipe multidisciplinar ${ }^{98}$, com o intuito de esmiuçar a proposta original do PCNEM de 1999. Nesse novo documento fica ainda mais explícito o papel do espaço geográfico como conceito principal e ponto de partida para a definição dos outros conceitos constantes da proposta curricular de Geografia: "o espaço geográfico é o elemento central dos conteúdos e das estruturas do conhecimento em Geografia e, por isso mesmo, constitui a espinha dorsal da própria disciplina". (BRASIL, 2002b, p. 58-59). O quadro 10 mostra isso na forma de diagrama:

98 O responsável pela Geografia foi o professor Álvaro José de Souza, de Botucatu (SP), antigo membro da Comissão Nacional de Ensino da Associação dos Geógrafos Brasileiros (AGB). Seu falecimento ocorreu antes da publicação do PCN + Ensino Médio em 2002, que foi dedicado a ele: "Para Álvaro José de Souza, amigo e geógrafo sem igual, a quem o destino não permitiu a possibilidade de ver chegar às mãos dos educadores brasileiros este material, do qual é co-autor e colaborador fundamental.” (BRASIL, 2002b). 


\section{Quadro 10. Conceitos de Geografia: PCN + Ensino Médio}

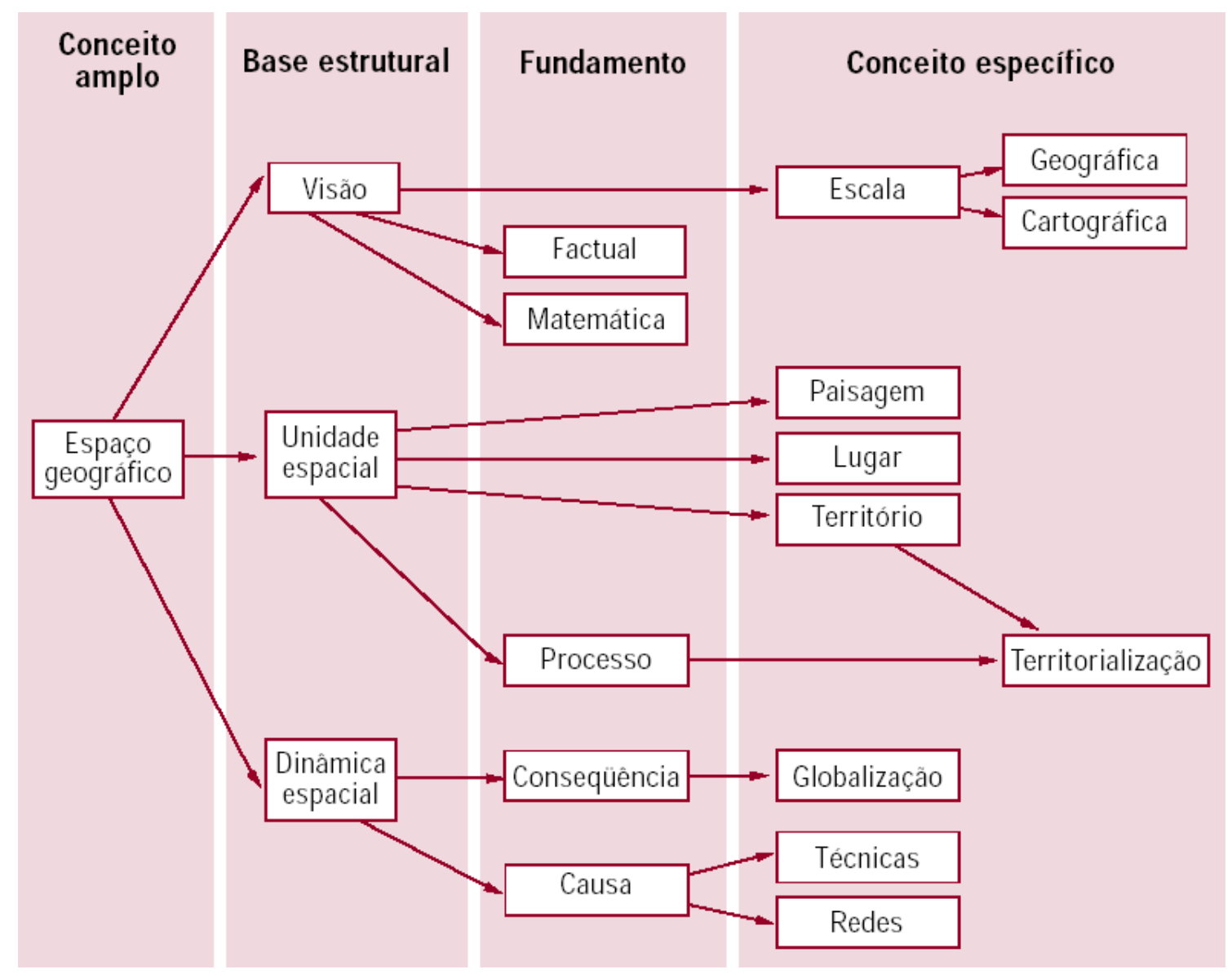

Fonte: Brasil (2002b, p. 59).

Numa tentativa de esclarecimento, os autores dos PCN + organizaram um diagrama (quadro 10) e um quadro (11) com os conceitos-chave da Geografia, os mesmos que já constavam dos primeiros PCNEM. A única diferença é que, nas versões originais, as definições desses conceitos apareciam no corpo do texto (BRASIL, 1999, p. 60-67; BRASIL, 2002a, p. 310-314). Entretanto, dando continuidade a seu espírito esmiuçador, os PCN + introduzem os "elementos de aprofundamento", que não constavam dos PCNEM originais: 


\section{Quadro 11. Resumo dos conceitos-chave de Geografia: PCN + Ensino Médio}

\begin{tabular}{|c|c|c|}
\hline Conceito & Concepção norteadora & Elementos de aprofundamento \\
\hline $\begin{array}{l}\text { Espaço } \\
\text { geográfico }\end{array}$ & $\begin{array}{l}\text { Conjunto indissociável de sistemas de objetos (redes } \\
\text { técnicas, prédios, ruas) e de sistemas de açoes } \\
\text { (organizaçăo do trabalho, produção, circulação, } \\
\text { consumo de mercadorias, relaçoes familiares e } \\
\text { cotidianas) que procura revelar as práticas sociais dos } \\
\text { diferentes grupos que nele produzem, lutam, sonham, } \\
\text { vivem e fazem a vida caminhar. (Milton Santos) }\end{array}$ & $\begin{array}{l}0 \text { espaço é perceptivel, sensivel, porém extrema- } \\
\text { mente dificil de ser limitado, quer por dinâmica, quer } \\
\text { pela vivência de elementos novos e elementos de } \\
\text { permanência. Apesar de sua complexidade, ele } \\
\text { apresenta elementos de unicidade. Interferem nos } \\
\text { mesmos valores, que sâo atribuidos pelo próprio ser } \\
\text { humano e que resultam numa distinção entre o } \\
\text { espaço absoluto - cartesiano - uma coisa em si } \\
\text { mesmo, independente; e um espaço relacional que } \\
\text { apresenta sentido (e valor) quando confrontado a } \\
\text { outros espaços e outros objetos. }\end{array}$ \\
\hline Paisagem & $\begin{array}{l}\text { Unidade visivel do arranjo espacial, alcançado por } \\
\text { nossa visăo. }\end{array}$ & $\begin{array}{l}\text { Contém elementos impostos pelo homem por meio } \\
\text { de seu trabalho, de sua cultura e de sua emoção. } \\
\text { Nela se desenvolve a vida social e, dessa forma, } \\
\text { ela pode ser identificada informalmente apenas, } \\
\text { mediante a percepçào, mas também pode ser } \\
\text { identificada e analisada de maneira formal, de modo } \\
\text { seletivo e organizado; e é neste último sentido que } \\
\text { a paisagem se compoe como um elemento con- } \\
\text { ceitual de interesse da Geografia. }\end{array}$ \\
\hline Lugar & $\begin{array}{l}\text { Porção do espaço apropriável para a vida, que é } \\
\text { vivido, reconhecido e cria identidade. }\end{array}$ & $\begin{array}{l}\text { Guarda em si mesmo as noçòes de densidade } \\
\text { técnica, comunicacional, informacional e normativa. } \\
\text { Guarda em si a dimensão da vida, como tempo } \\
\text { passado e presente. É nele que ocorrem as relaçoes } \\
\text { de consenso, conflito, dominação e resistência. É } \\
\text { nele que se dá a recuperaçăo da vida. É o espaço } \\
\text { com o qual o individuo se identifica mais diretamente. }\end{array}$ \\
\hline Território & $\begin{array}{l}\text { Porção do espaço definida pelas relaçoes de poder, } \\
\text { passando assim da delimitaçăo natural e economica } \\
\text { para a de divisa social. } \\
0 \text { grupo que se apropria de um território ou se } \\
\text { organiza sobre ele cria relação de territorialidade, que } \\
\text { se constitui em outro importante conceito da } \\
\text { Geografia. Ela se define como a relação entre os } \\
\text { agentes sociais politicos e economicos, interferindo } \\
\text { na geståo do espaço. }\end{array}$ & $\begin{array}{l}\text { A delimitação do território è a delimitação das } \\
\text { relaçoes de poder, dominio e apropriação nele } \\
\text { instaladas. É portanto uma porção concreta. } 0 \\
\text { território pode, assim, transcender uma unidade } \\
\text { politica, e o mesmo acontecendo com o processo } \\
\text { de territorialidade, sendo que este não se traduz } \\
\text { por uma simples expressão cartográfica, mas se } \\
\text { manifesta sob as relaçoes variadas, desde as mais } \\
\text { simples até as mais complexas. }\end{array}$ \\
\hline Escala & $\begin{array}{l}\text { Distinguem-se dois tipos ou duas visoes básicas: a } \\
\text { escala cartográfica e a escala geográfica. A primeira } \\
\text { delas é, a priori, uma relação matemática que implica } \\
\text { uma relação numérica entre a realidade concreta e a } \\
\text { realidade representada cartograficamente. } \\
\text { No caso da escala geográfica, trata-se de uma visão } \\
\text { relativa a elementos componentes do espaço } \\
\text { geográfico, tomada a partir de um direcionamento } \\
\text { do olhar cientifico: uma escala de análise que } \\
\text { procura responder os problemas referentes à } \\
\text { distribuição dos fenomenos. }\end{array}$ & $\begin{array}{l}\text { Para a escala cartográfica, é essencial estabelecer } \\
\text { os valores numéricos entre o fato representado e a } \\
\text { dimensão real do fato ocorrente. No entanto, essa } \\
\text { relação pode pressupor a escolha de um grau de } \\
\text { detalhamento que implique a inclusão de fatos mais } \\
\text { ou menos visiveis, dentro de um processo seletivo } \\
\text { que considere graus de importância para o processo } \\
\text { de representação. } \\
\text { No caso da escala geográfica, o que comanda a } \\
\text { seleçào dos fatos è a ordem de importância dos } \\
\text { mesmos no contexto do tema que está sendo } \\
\text { trabalhado. Há, nesse caso, uma seleção efetiva dos } \\
\text { fatos a partir dos diversos niveis de análise, que já } \\
\text { se tentou agrupar em unidades de grandeza, o que } \\
\text { pode ser discutivel. }\end{array}$ \\
\hline $\begin{array}{c}\text { Globalização, } \\
\text { técnicas } \\
\text { e redes }\end{array}$ & $\begin{array}{l}0 \text { fato gerador é o processo de globalizaçăo, que } \\
\text { corresponde a uma etapa do processo de imple- } \\
\text { mentação de novas tecnologias, que acabaram por } \\
\text { criar a intercomunicaçăo entre os lugares em tempo } \\
\text { simultâneo. Para sua ocorência, torna-se fundamental } \\
\text { a apreensão das técnicas pelo ser humano e a } \\
\text { expressão das redes, que nâo se restringem à } \\
\text { comunicaçăo, mas englobem todos os sistemas de } \\
\text { conexăo entre os lugares. }\end{array}$ & $\begin{array}{l}\text { A globalização é basicamente assegurada pela } \\
\text { implementaçăo de novas tecnologias de comunicação } \\
\text { e informação, isto é, de novas redes técnicas que } \\
\text { permitem a circulação de idéias, mensagens, pessoas } \\
\text { e mercadorias, num ritmo acelerado, criando a } \\
\text { interconexâo dos lugares em tempo simultâneo. }\end{array}$ \\
\hline
\end{tabular}

Fonte: Brasil (2002b, p. 56). 
Entretanto, extrapolando esse espírito esmiuçador e em flagrante contradição com a proposta interdisciplinar dos PCNEM originais, os PCN + introduzem uma novidade que: uma lista de conteúdos, os chamados "eixos temáticos" (BRASIL, 2002b). São quatro eixos - "A dinâmica do espaço geográfico", "O mundo em transformação: as questões econômicas e os problemas geopolíticos", "O homem criador de paisagem/modificador do espaço", "O território brasileiro: um espaço globalizado" -, cada um deles dividido em 4 temas e diversos subtemas (ver anexo B).

Deve ser lembrado que, na proposta inicial dos PCNEM, não aparecia nenhuma lista de conteúdos, apenas um quadro com as competências e habilidades a serem desenvolvidas em Geografia (BRASIL, 1999, 2002a), conforme consta do anexo C. As mesmas competências e habilidades aparecem novamente no PCN + diluídas ao longo do texto no subtítulo "O significado das competências específicas da Geografia" (BRASIL, 2002b, p. 60-64).

\section{As OCEM E O ESPaÇo: CONCEITO OU CATEgoria?}

Como foi comentado anteriormente, a contradição entre a proposta interdisciplinar dos PCNEM e a lista de conteúdos dos PCN + - os "eixos temáticos" - foi apontada no capítulo que trata da Geografia nas Orientações Curriculares do Ensino Médio (BRASIL, 2004a, p. 325). Apesar disso, como também já foi comentado, na proposta final das OCEM (BRASIL, 2006), embora mais enxuta, aparece uma nova lista de conteúdos no subtítulo "Os eixos temáticos: a articulação entre os conceitos e os conteúdos" (abaixo), como se percebe bem diferente da que consta do anexo B:

- Formação territorial brasileira.

- Estrutura e dinâmica de diferentes espaços urbanos e o modo de vida na cidade, o desenvolvimento da geografia urbana mundial.

- O futuro dos espaços agrários, a globalização, a modernização da agricultura no período técnico-científico-informacional e a manutenção das estruturas agrárias tradicionais como forma de resistência. 
- Organização e distribuição mundial da população, os grandes movimentos migratórios atuais e os movimentos socioculturais e étnicos, as novas identidades territoriais.

- As diferentes fronteiras e a organização da geografia política do mundo atual, Estado e organização do território.

- As questões ambientais, sociais e econômicas resultantes dos processos de apropriação dos recursos naturais em diferentes escalas, grandes quadros ambientais do mundo e sua conotação geopolítica.

- Produção e organização do espaço geográfico e mudanças nas relações de trabalho, inovações técnicas e tecnológicas e as novas geografias, a dinâmica econômica mundial e as redes de comunicação e informação. (BRASIL, 2006, p. 57-59).

Além dos novos eixos temáticos, nas OCEM (BRASIL, 2006) aparece também uma nova lista de competências e habilidades (anexo D). Já que os autores são outros e é diferente o enfoque teórico-metodológico, assim como a seleção de conceitos, categorias e conteúdos, a lista da OCEM (anexo D) é diferente daquela do PCNEM (anexo C). Claro, há muitas coincidências, afinal compreender o mundo na perspectiva da Geografia sempre implicará saber "utilizar a linguagem cartográfica", "operar com os conceitos básicos da Geografia" (a questão é, como veremos a seguir: quais são eles?) e "analisar o espaço geográfico em diferentes escalas cartográficas e geográficas” (BRASIL, 1999, 2002a; BRASIL, 2006).

Os autores ${ }^{99}$ do capítulo sobre a Geografia da versão preliminar das Orientações Curriculares do Ensino Médio (BRASIL, 2004a) não concordam com o enfoque teórico-metodológico da proposta do PCNEM (BRASIL, 1999, 2002a) e do PCN + (BRASIL, 2002b). Aquele documento critica a definição dos conceitos-chave e a proposta dos eixos temáticos da Geografia baseados no conceito de espaço geográfico elaborado por Milton Santos. Seus autores argumentam que esse conceito, ancorado em um pensamento estruturalista, dificultaria o tratamento interdisciplinar:

A organização dos eixos temáticos em Geografia e seus desdobramentos em subtemas, por exemplo, estão baseados, fundamentalmente, no conceito de espaço geográfico elaborado por Milton Santos e se prende a essa forma de pensar, de base estruturalista. Como as bases teóricas dos outros campos disciplinares não são, necessariamente, as mesmas e, em função do "caráter fechado" que caracteriza a

99 Eliseu Savério Sposito e Maria Encarnação Beltrão Sposito, professores do Departamento de Geografia da Faculdade de Ciências e Tecnologia da Universidade Estadual Paulista (UNESP), campus de Presidente Prudente-SP. 
forma estruturalista de elaborar o pensamento, a relação interdisciplinar com os outros componentes fica dificultada. (BRASIL, 2004a, p. 325).

Em outra passagem, insistindo na crítica à concepção teóricometodológica adotada, os autores afirmam:

Uma segunda apreciação sobre os conceitos estruturantes do documento leva à reflexão sobre a tendência teórica adotada. Ela se baseia, ao eleger o espaço geográfico como conceito norteador dos demais conceitos, numa concepção de Geografia que se consolidou no Brasil pela corrente estabelecida pelo pensamento de Milton Santos. Não é demérito nenhum se orientar por tal perspectiva; no entanto, arrisca-se esquecer a sociedade como objeto de estudo da Geografia, ao se privilegiar forma, função, estrutura e processo, elementos fundamentais para a leitura do espaço geográfico, segundo essa perspectiva. (BRASIL, 2004a, p. 337).

Quase no final do documento ainda reafirmam:

Como afirmado anteriormente, ao se orientar por tal tendência teórica arrisca-se negligenciar a sociedade como objeto científico e filosófico de uma proposta curricular, ficando limitado apenas à compreensão do espaço geográfico. (BRASIL, 2004a, p. 338).

Mas, como compreender o espaço geográfico sem compreender a sociedade? Ou, por outro lado, como compreender a sociedade sem compreender o espaço geográfico? Esses conceitos não são separados como sugere o trecho acima e não podem ser compreendidos e operacionalizados isoladamente, pelo menos não do ponto de vista de uma Geografia preocupada em apreender a dialética sócio-espacial. O próprio Milton Santos nunca propôs essa separação, muito pelo contrário. Desde seu famoso ensaio Sociedade e espaço: a formação social como teoria e como método ${ }^{100}$, publicado no Boletim Paulista de Geografia $n^{\circ}$ 54 (SANTOS, 1977) e depois no livro Espaço e sociedade (SANTOS, 1979), ele sempre defendeu a inseparabilidade entre a sociedade e o espaço geográfico por ela produzido:

Se a Geografia deseja interpretar o espaço humano como o fato histórico que ele é, somente a história da sociedade mundial, aliada à da sociedade local, pode servir como fundamento à compreensão da realidade espacial e permitir a sua transformação a serviço do homem. Pois a História não se escreve fora do espaço e não há sociedade a-espacial. O espaço, ele mesmo, é social. (SANTOS, 1979, p. 9-10).

\footnotetext{
100 Este artigo foi publicado inicialmente em Antipode, n. 1, vol. 9, jan./fev. 1977.
} 
Depois de propor o conceito de formação sócio-espacial derivado da categoria marxista formação econômico social e como uma tentativa de concretizá-la espacialmente, ele assim conclui seu ensaio:

Como pudemos esquecer por tanto tempo esta inseparabilidade das realidades e das noções de sociedade e de espaço inerentes à categoria da formação social? Só o atraso teórico conhecido por essas duas noções pode explicar que não se tenha procurado reuni-las num conceito único. Não se pode falar de uma lei separada da evolução das formações espaciais. De fato, é de formações sócio-espaciais que se trata. (SANTOS, 1979, p. 19).

Enfim, não dá para falar em formação econômico social sem considerar o espaço geográfico, base de qualquer sociedade nacional. Há diversos autores que corroboram essa forma de pensar a relação sociedade-espaço.

Teorizando sobre o conceito de espaço geográfico no artigo Espaço: um conceito-chave da Geografia, após citar o ensaio acima, Roberto Lobato Corrêa afirma:

O mérito do conceito de formação sócio-espacial, ou simplesmente formação espacial, reside no fato de se explicitar teoricamente que uma sociedade só se torna concreta através de seu espaço, do espaço que ela produz e, por outro lado, o espaço só é inteligível através da sociedade. Não há, assim, por que falar de sociedade e espaço como se fossem coisas separadas que nós reunimos a posteriori, mas sim de formação sócio-espacial. (CORRÊA, 1995, p. 26-27).

Superando a proposta original de Milton Santos, nesse artigo Roberto Lobato propõe que a formação sócio-espacial seja considerada meta-conceito que contém e está contida nos conceitos-chave de natureza operativa da Geografia. Vale lembrar, entretanto, que o conceito de formação sócio-espacial só pode ser aplicado à escala do território nacional.

Armando Corrêa da Silva também fazendo referência ao mesmo ensaio de Milton Santos assevera: "não existe uma formação espacial separada das formações sociais, pois são parte de uma mesma realidade dialética." (SILVA, 1986, p. 35).

No livro $A$ natureza do espaço, Milton Santos propõe que: "O espaço é formado por um conjunto indissociável, solidário e também contraditório, de sistemas de objetos e sistemas de ações, não considerados isoladamente, mas como o 
quadro único no qual a história se dá." (SANTOS, 1996a, p. 51). Incorporou em sua tentativa de construção desse conceito, que sempre viu como algo dinâmico, a noção de rede, em que o sistema de objetos é a paisagem, cada vez mais artificializada, e o sistema de ações é a sociedade, cada vez mais globalizada. E ambos compõem o espaço geográfico.

Embora uma parte do pensamento de Milton Santos possa ter recebido influência do estruturalismo, possivelmente de Althusser ${ }^{101}$, ele recebeu influências maiores de outras correntes filosóficas. Foi visivelmente influenciado pelo "marxismo de Marx", para lembrar Aron (2005), e também pelo marxismo de Lefebvre, visceralmente contrário a qualquer dogmatismo. Foi também influenciado por Sartre, tanto pelo existencialismo, que é uma filosofia diametralmente oposta ao estruturalismo, como pelo marxismo renovado de Crítica da razão dialética. Nesse livro, Sartre destaca a importância das idéias de Marx, mas critica o dogmatismo e a desvalorização do sujeito e da História imposto por seus seguidores. Ao mesmo tempo, faz uma tentativa de renovar o marxismo e conjugá-lo com o existencialismo.

Como vimos na discussão sobre o método (capítulo 2, parte I), tanto Lefebvre quanto Sartre fizeram uma profunda crítica ao marxismo ortodoxo, à instrumentalização do materialismo dialético pelo Estado soviético, levando à sua fossilização.

Assim, tachar o pensamento de Milton Santos de estruturalista esconde essa pluralidade de influências e limita artificialmente a possibilidade de compreensão do mundo por meio de sua proposta teórica. Sem contar que, como nos lembra Hubert Lepargneur, não dá para falar em estruturalismo, mas sim em estruturalismos e "mesmo na lingüística, o estruturalismo é mais uma tendência, um espírito metodológico do que uma escola com sua dogmática estabelecida". (LEPARGNEUR, 1972, p. 21).

O fato de Milton Santos ter definido o espaço geográfico como sistema de objetos e sistema de ações e de trabalhar com as categorias de forma, função, estrutura e processo, não quer dizer que ele tenha desprezado o sujeito, a

101 Não há nos livros de Milton Santos, especialmente no mais importante - A natureza do espaço -, referências a autores estruturalistas como Saussure, Lévi-Strauss ou Althusser. Há apenas uma referência ao livro Ler o capital, de Althusser, em Por uma Geografia nova (SANTOS, 1980). Por outro lado, os livros mais importantes de Sartre, Lefebvre e, evidentemente, Marx permeiam sua obra. 
sociedade e a História, como fica patente em diversas passagens de seus livros, algumas das quais mencionadas ao longo deste trabalho, como a que aparece no trecho a seguir. Embora estrutura e função sejam claramente categorias do estruturalismo, forma e processo já não the são específicas. Aliás, Santos (1996a) mais de uma vez enfatizou que falava de forma-conteúdo, categorias da dialética, como veremos a seguir.

Milton Santos, ao questionar se é possível pensar em uma dialética entre a sociedade e a paisagem ou se ela somente se daria entre a sociedade e o espaço, assim conclui:

Quando a sociedade age sobre o espaço, ela não o faz sobre os objetos como realidade física, mas como realidade social, formas-conteúdos, isto é objetos sociais já valorizados aos quais ela (a sociedade) busca oferecer ou impor um novo valor. A ação se dá sobre objetos já agidos, isto é, portadores de ações concluídas, mas ainda presentes. Esses objetos da ação são, desse modo, dotados de uma presença humana e por ela qualificados.

$[\ldots]$

Em cada momento, em última análise, a sociedade está agindo sobre ela própria, e jamais sobre a materialidade exclusivamente. A dialética, pois não é entre sociedade e paisagem, mas entre sociedade e espaço. E vice-versa. (SANTOS, 1996a, p. 88).

Sua resposta é clara. Aliás, a idéia de uma dialética sócio-espacial pode ser encontrada também em Smith (1988) e Soja (1993). Edward Soja defende que:

A estrutura do espaço organizado não é uma estrutura separada, com suas leis autônomas de construção e transformação, nem tampouco é simplesmente uma expressão da estrutura de classes que emerge das relações sociais (e, por isso, aespaciais?) de produção. Ela representa, ao contrário, um componente dialeticamente definido das relações de produção gerais, relações estas que são simultaneamente sociais e espaciais. (SOJA, 1993, p. 99).

Neil Smith, entretanto, vai além e questiona a idéia de que o espaço e a sociedade "interagem" ou que os padrões espaciais "refletem" a estrutura social. "Duas coisas somente podem interagir ou refletir-se mutuamente se elas forem definidas, em primeiro lugar, como coisas separadas." (SMITH, 1988, p. 122-123). Para ele, essa visão permanece presa à concepção absoluta de espaço. Em seguida, acrescenta que "é difícil começar a partir de uma concepção implicitamente dualista do espaço e da sociedade e concluir demonstrando sua unidade". (SMITH, 1988, p. 123, grifo do autor). Para superar essa contradição, retoma Henri Lefebvre 
e, com base na noção de "produção do espaço" ${ }^{102}$, propõe que mais do que afirmar é possível demonstrar a unidade do espaço e da sociedade. Nas palavras de Smith (1988, p. 123):

Com a "produção do espaço", a prática humana e o espaço são integrados no nível do "próprio" conceito de espaço. O espaço geográfico é visto como um produto social; nesta concepção, um espaço geográfico que é abstraído da sociedade torna-se uma "amputação" filosófica.

Milton Santos nunca pretendeu a "amputação" filosófica que the foi imputada pelo documento preliminar das Orientações Curriculares do Ensino Médio (BRASIL, 2004a). O trecho transcrito na página anterior não deixa a menor dúvida sobre a inseparabilidade de sociedade e espaço na teoria proposta por Milton Santos e sobre o fato de ele acreditar que, quando a sociedade age sobre o espaço, ela está agindo sobre si própria e nunca sobre a materialidade apenas. No fim das contas, quem acabou cometendo tal "amputação" foi o documento do MEC. Ao argumentar que o enfoque teórico de Milton Santos "arrisca-se negligenciar a sociedade como objeto científico e filosófico de uma proposta curricular", implicitamente corrobora que com isso tal enfoque ficaria "limitado apenas à compreensão do espaço geográfico". (BRASIL, 2004a, p. 338). Se assim fosse, então a teoria de Milton Santos não permitiria compreender nem mesmo o espaço geográfico. Voltamos à indagação: como é possível compreender o espaço geográfico "mutilado", abstraído da sociedade?

A sociedade não "está" no espaço, ela "é" o espaço produzido, portanto não é possível compreender o espaço geográfico isolado da sociedade. Como diz Smith (1988, p. 132):

A idéia de que as coisas acontecem "no espaço" não é somente um hábito do pensamento mas também um hábito da linguagem, e apesar de seu apelo ao absoluto, o espaço natural é anacrônico, até mesmo nostálgico e uma barreira a uma compreensão crítica do espaço. Por suas ações, a sociedade não mais aceita o espaço como um receptáculo, mas sim o produz; nós não vivemos, atuamos ou trabalhamos "no" espaço, mas sim produzimos o espaço, vivendo, atuando e trabalhando.

\footnotetext{
102 “Puntualicemos: 'producción del espacio', y no de tal o cual objeto, de tal o cual cosa en el espacio."
} (LEFEBVRE, 1976, p. 119). 
Nesse sentido, parece-me um retrocesso desprezar o conceito de espaço geográfico, como ocorreu no documento final das Orientações Curriculares para o Ensino Médio (BRASIL, 2006). Na nova seleção de conceitos-chave da disciplina, não consta mais o espaço geográfico. Em seu lugar entram "espaço e tempo", mas tomados como categoria filosófica, portanto com alto grau de generalidade. Para Silva (1986, p. 27): "A filosofia é o nível do conhecimento mais geral que se pode conceber. É nela, portanto, que as categorias, como determinações da existência, possuem seu grau mais amplo de generalidade.". O quadro 12 permite a comparação dos conceitos-chave constantes dos PCNEM (BRASIL, 1999, 2002a) e PCN + (BRASIL, 2002b), de um lado, e das OCEM (BRASIL, 2006), de outro:

\begin{tabular}{|c|c|}
\hline \multicolumn{2}{|c|}{$\begin{array}{l}\text { Quadro 12. Conceitos-chave de Geografia nos } \\
\text { documentos do MEC }\end{array}$} \\
\hline \begin{tabular}{|l} 
Parâmetros Curriculares \\
Nacionais do Ensino Médio*
\end{tabular} & $\begin{array}{l}\text { Orientações Curriculares para } \\
\text { o Ensino médio** }\end{array}$ \\
\hline - Espaço geográfico & - Espaço e tempo \\
\hline - Paisagem & - Sociedade \\
\hline - Lugar & - Paisagem \\
\hline - Território & - Lugar \\
\hline - Escala & - Território \\
\hline - Globalização, técnicas e redes & • Região \\
\hline
\end{tabular}

Fonte: *Brasil (1999, 2002a, 2002b); **Brasil (2006).

Nas OCEM (2006), "espaço e tempo" são tratados como categoria - o que de fato são - e não como conceitos geográficos:

Os conceitos cartográficos (escala, legenda, alfabeto cartográfico) e os geográficos (localização, natureza, sociedade, paisagem, região, território e lugar) podem ser perfeitamente construídos a partir das práticas cotidianas. Na realidade, trata-se de realizar a leitura da vivência do lugar em relação com um conjunto de conceitos que estruturam o conhecimento geográfico, incluindo as categorias espaço e tempo. (BRASIL, 2006, p. 50, grifo nosso).

Passam, assim, a ser considerados categorias de interface para se trabalhar com os conceitos geográficos: "Ao trabalhar com os conceitos cartográficos e geográficos, tendo como interface as categorias de espaço e tempo, temos de 
incorporar outros componentes que servirão de referências curriculares para o ensino médio [...]" (BRASIL, 2006, p. 50).

Nesse ponto, para avançar esta discussão, torna-se necessária uma breve análise dos significados de conceito e de categoria.

Sobre conceito não há muito a acrescentar à definição dada pelas OCEM:

Um conceito é a representação das características gerais de cada objeto pelo pensamento. Nesse sentido, conceituar significa a ação de formular uma idéia que permita, por meio de palavras, estabelecer uma definição, uma caracterização do objeto a ser conceituado. (BRASIL, 2006, p. 52).

Nicola Abbagnano, por sua vez, assim define conceito:

En general, todo procedimiento que posibilite la descripción, la clasificación y la previsión de los objetos cognoscibles. Entendido de tal manera, el término tiene un significado muy general y puede incluir toda especie de signo o procedimiento semántico, cualquiera que se sea el objeto al que se refiera, abstracto o concreto, cercano o lejano, universal o individual, etc. (ABBAGNANO, 1998, p. 190).

Assim, qualquer conceito por definição é dinâmico. Como tentativa de apreender a realidade no plano do pensamento, deve mudar à medida que a realidade que busca apreender se transforma.

A definição de categoria é um pouco mais complexa. Japiassu e Marcondes (2006), depois de retomarem sua origem aristotélica e, posteriormente, kantiana, nos lembram que hoje categoria é muitas vezes usada como sinônimo de noção ou de conceito. De fato, é comum identificarmos esse uso indiscriminado, que muitas vezes pode gerar confusões ou interpretações errôneas. Como nos alerta Harvey (1980, p. 13): "Se nossos conceitos são inadequados ou inconsistentes, não podemos esperar identificar problemas e formular soluções políticas apropriadas.". Falava referindo-se à cidade, mas isso vale para qualquer objeto cognoscível. Poderíamos parafraseá-lo: "Se nossas [categorias] são inadequadas ou inconsistentes, não podemos esperar identificar problemas e formular soluções [...]" Portanto, antes de tudo, é de suma importância discernir claramente os conceitos das categorias e identificá-los adequadamente numa determinada concepção teórico-metodológica, preservando assim seu potencial heurístico. 
De acordo com Mora (2001, p. 82), "a mais importante doutrina moderna das categorias é a de Kant". Para esse filósofo alemão, as categorias são conceitos puros do entendimento de que o sujeito dispõe a priori na consciência e aplica aos objetos, aos fenômenos, no decorrer do processo da atividade cognitiva (ABBAGNANO, 1998; CHAPTULIN, 1982; MORA, 2001). Não servem para descrever a realidade, mas tornam possível sua explicação. Kant enumerava doze categorias, em quatro grupos, que correspondiam às classes de juízos. Segundo Abbagnano (1998, p. 149) e Mora (2001, p. 82), as categorias kantianas são as de:

- Quantidade: unidade, pluralidade, totalidade

- Qualidade: realidade, negação, limitação

- Relação: substância e acidente, causa e efeito, comunidade e reciprocidade

- Modalidade: possibilidade-impossibilidade, existência-não existência, necessidade-contingência.

Abbagnano (1998) diz que a concepção kantiana de categoria permanece imutável na filosofia inspirada em Kant. Entretanto, tal concepção não é única na filosofia moderna e contemporânea. No empirismo lógico, por exemplo, as categorias são consideradas regras convencionais que presidem o uso dos conceitos. Para Mora (2001), os sistemas de categoria proliferaram desde as últimas décadas do século XIX e o início do XX. A seguir, um dos exemplos dados para justificar tal proliferação:

Segundo Paul Natorp, há três tipos de categorias básicas (Grundkategorien):

(1) Categorias da modalidade (repouso, movimento, possibilidade, contradição, necessidade, criação, etc.);

(2) Categorias da relação (quantidade, qualidade, "figuração", concentração, autoconservação, etc.);

(3) Categorias da individuação (propriedade, quantificação, continuidade, espaço, tempo, etc.). (MORA, 2001, p. 84).

Na leitura de Cheptulin (1982, p. 140), para quem o pensamento de Paul Natorp era idealista, no materialismo dialético as categorias "não são apenas graus do desenvolvimento da consciência, mas também graus do desenvolvimento da prática social dos homens, de suas relações entre eles e deles com a natureza". Essa idéia de que as categorias são graus, momentos do desenvolvimento do 
conhecimento, Cheptulin busca em Lenin. Portanto, assim como os conceitos, as categorias não são eternas. No curso do desenvolvimento do conhecimento surgem novas categorias, que passam a se relacionar com as já existentes, que por sua vez podem mudar de significado. Para Cheptulin (1982), as categorias da dialética, como graus de desenvolvimento do conhecimento que expressam a unidade do histórico e do lógico, são os pares:

- Matéria e consciência

- Espaço e tempo

- Singular e geral, particular e universal

- Qualidade e quantidade

- Causa e efeito

- Necessidade e contingência

- Forma e conteúdo

- Essência e fenômeno

No livro A dialética materialista, esse filósofo russo busca estabelecer relações entre essas categorias e as leis da dialética enunciadas por Engels (2000) e Lefebvre (1991), conforme vimos no capítulo sobre o método (capítulo 2, parte I). Para Cheptulin (1982, p. 345):

As leis da dialética refletem as ligações e as relações universais, enquanto que as categorias refletem, além disso, as propriedades e os aspectos universais da realidade objetiva, o que faz com que o conteúdo das categorias revele-se mais rico do que o das leis.

Como se pode perceber pela leitura das três listas acima, há uma multiplicidade de categorias, e sua definição é uma das questões mais complexas da Filosofia. Num esforço de simplificação e síntese, fiquemos então com a definição introdutória do dicionário de Abbagnano (1998, p. 147): "Categoría. En general, cualquier noción que sirva como regla para la investigación o para su expresión lingüística en un campo cualquiera.". Na continuação, ele escreve o equivalente a três páginas na tentativa de esclarecer esse verbete. Japiassu e Marcondes (2006, p. 41), depois de constatarem que categoria é freqüentemente considerada sinônimo 
de noção ou de conceito, afirmam que esse termo "designa, mais adequadamente, a unidade de significação de um discurso epistemológico".

Assim, cada autor define suas próprias categorias, dependendo de sua orientação teórico-metodológica ou de seu campo disciplinar. No entanto, há algumas coincidências. Por exemplo, espaço e tempo aparecem como categorias tanto na lista do filósofo neokantiano alemão Paul Natorp como na do filósofo marxista soviético Alexandre Chaptulin.

Voltando às Orientações Curriculares para o Ensino Médio: a principal fonte de inspiração teórica para a seleção dos conceitos estruturantes da Geografia constantes desse documento (BRASIL, 2006) foi o livro Geografia e filosofia, de Eliseu Savério Sposito. Depois de explicitar sua concepção acerca dos métodos científicos (capítulo 1) e de fazer uma discussão sobre epistemologia (capítulo 2), Sposito (2004) envereda pela revisão e redefinição de conceitos-chave do pensamento geográfico: espaço (e tempo), região e território (capítulo 3).

Para justificar a importância de tratar espaço e tempo como categoria, recorre a Kant:

É Kant que vai conceber o tempo e o espaço como categorias filosóficas fundamentais para a compreensão da realidade. Sem estas, a existência não seria possível porque não se pode conceber nada antes, depois ou mesmo sem tempo e espaço. (SPOSITO, 2004, p. 97).

Baseia-se em Piettre (1997) para discutir espaço e tempo na perspectiva da Física, desde Newton, com o espaço absoluto, até Einstein, com o espaço relativo. Depois de toda essa genealogia, indaga, do ponto de vista do leitor: "por que tanta discussão sobre o tempo e o espaço na perspectiva da Física?" Sua resposta:

[...] não se pode compreender essa categoria, nem mesmo no campo restrito dos estudos geográficos, sem compreendê-la, minimamente, em suas diversas dimensões e interpretações elaboradas por diferentes pensadores em diferentes áreas do conhecimento. (SPOSITO, 2004, p. 100).

Depois de fazer a genealogia das conceituações de espaço em autores como Henri Lefebvre, David Harvey, Edward Soja, Milton Santos, Roberto Lobato e uma discussão sobre as categorias "espaço e tempo" na Filosofia e na Física com base em Bernard Piettre, afirma Sposito (2004, p. 100): 
As categorias tempo e espaço (ou espaço e tempo, a ordem não interessa nesse caso) condicionam a compreensão da realidade, sobretudo no momento atual, quando o avanço científico que permite grande velocidade na circulação das comunicações deflagra novos paradigmas para a compreensão das escalas que afetam o espaço e o tempo e, conseqüentemente, a vida cotidiana das pessoas nos mais distantes territórios do planeta.

O problema é que tomar espaço e tempo como categorias da Filosofia ou como conceitos da Física não contribui muito para a compreensão do espaço como conceito sócio-espacial, como produção humana, como morada do homem e, conseqüentemente, nem para sua operacionalização no processo de compreensão do mundo na perspectiva da Geografia. Aliás, na Física, depois de Einstein, devemos falar não em "espaço e tempo", mas em "espaço-tempo"103, como um conceito único, um contínuo espaço-temporal de quatro dimensões composto pelas coordenadas $\mathrm{x}, \mathrm{y}, \mathrm{z}$ e t. Como nos lembra Stephen Hawking, a teoria da relatividade nos força a mudar fundamentalmente os conceitos de espaço e tempo. Para esse físico inglês: "Devemos aceitar que o tempo não é completamente isolado e independente do espaço, mas sim que eles se combinam para formar um elemento chamado espaço-tempo." (HAWKING, 1988, p. 46).

Milton Santos é um dos que manifesta seu ceticismo quanto à possibilidade de operacionalização do conceito de espaço-tempo dos físicos na análise geográfica do mundo banal:

Quando Parkes \& Thrift (1980, p. 279) diziam que "com o movimento, o espaço e o tempo se tornam coincidentes como espaço-tempo", isso é, certamente, válido como princípio da Física. É menos certo - ou totalmente incerto - que possamos mecanicamente transcrever esse raciocínio para uma disciplina histórica como a Geografia. Em uma geografia do movimento, espera-se, em primeiro lugar, reconhecer o encontro de um tempo real e de um espaço real. Não é sempre o caso. (SANTOS, 1996a, p. 42).

Bem antes dele, David Harvey já havia manifestado o mesmo ceticismo:

103 A expressão espaço-tempo foi criada em 1908 por Minkowski para designar as quatro dimensões (x, y, z e t) necessárias para situar um evento de acordo com a teoria da relatividade (DUROZOI; ROUSSEL, 1996). De acordo com Einstein (1999, p. 49) "o mundo dos eventos físicos que Minkowski chama simplesmente o 'mundo', ou 'universo', é naturalmente de quatro dimensões no sentido espaço-temporal. Pois ele se compõe de eventos individuais, cada um dos quais descrito por quatro números, a saber, as três coordenadas espaciais $x, y, z$ e uma coordenada temporal, o valor do tempo $t$ ". 
Há, naturalmente, uma literatura bastante substantiva que trata da filosofia do espaço. Infelizmente, a maior parte diz respeito à interpretação do significado do espaço tal como ele é conceituado na física moderna, sendo, útil, às vezes; mas é antes de tudo, uma visão específica do espaço, e não estou certo de que isso tenha qualquer validade geral para o exame da atividade social. (HARVEY, 1980, p. 18).

Para Milton Santos, o casamento entre o espaço real e o tempo real se dá por meio da técnica. É por meio dela que se pode empiricizar o tempo, transformando-o em algo real, concreto, componente do espaço geográfico. "É por intermédio das técnicas que o homem, no trabalho, realiza essa união entre espaço e tempo. [...] A técnica é, pois, um dado constitutivo do espaço e do tempo operacionais e do espaço e do tempo percebidos." (SANTOS, 1996a, p. 44-45). Assim, a técnica tem o poder de empiricizar, no espaço geográfico, não apenas o tempo histórico, mas também o tempo físico. O tempo histórico é concretizado pelo trabalho humano, por meio da existência de objetos de idades diferentes construídos na paisagem, que, como nos disse Santos (1996a), é uma acumulação desigual de tempos. A cidade, em especial, é visivelmente uma coleção de objetos técnicos de idades diferentes: edifícios comerciais e residenciais, escolas, museus, antenas, usinas, estradas, pontes etc. O tempo físico, por sua vez, pode ser empiricizado por meio da circulação, através da velocidade desigual de deslocamento, pela transposição desigual das distâncias entre os lugares, pela convergência do tempoespaço, como disse Leyshon (1995).

De fato, como fica evidente pela leitura do mapa do espaço relativo, que mostra a convergência do tempo-espaço na bacia do Pacífico (figura 4, direita), os lugares que convergiram entre si - São Francisco, Tóquio e Sydney - o fizeram porque são espaços geográficos mais densos de objetos técnico-informacionais redes de transportes e de telecomunicações -, importantes nós da rede global de cidades, nos quais houve maior acúmulo de capital. São, portanto, mais bem equipados para dar sustentação a essa convergência, que nada mais é do que o resultado da redução do tempo de deslocamento de pessoas, mercadorias, capitais e informações. Entretanto, é importante lembrar que a convergência no tempoespaço é desigual também para as pessoas, mesmo as que habitam os nós das redes. Aquelas que possuem maior renda e mais acesso aos objetos técnicoinformacionais têm mais mobilidade e maiores oportunidades. Santos (1996b) 
acertadamente já afirmou que até mesmo o grau de cidadania das pessoas varia dependendo da localização delas no território - outra modalidade do espaço geográfico. As possibilidades são diferentes dependendo da posição em que cada um se encontra no território. 


\section{Figura 4. Bacia do Pacífico: a) mapa "convencional", b) mapa do tempo-espaço*}

a)

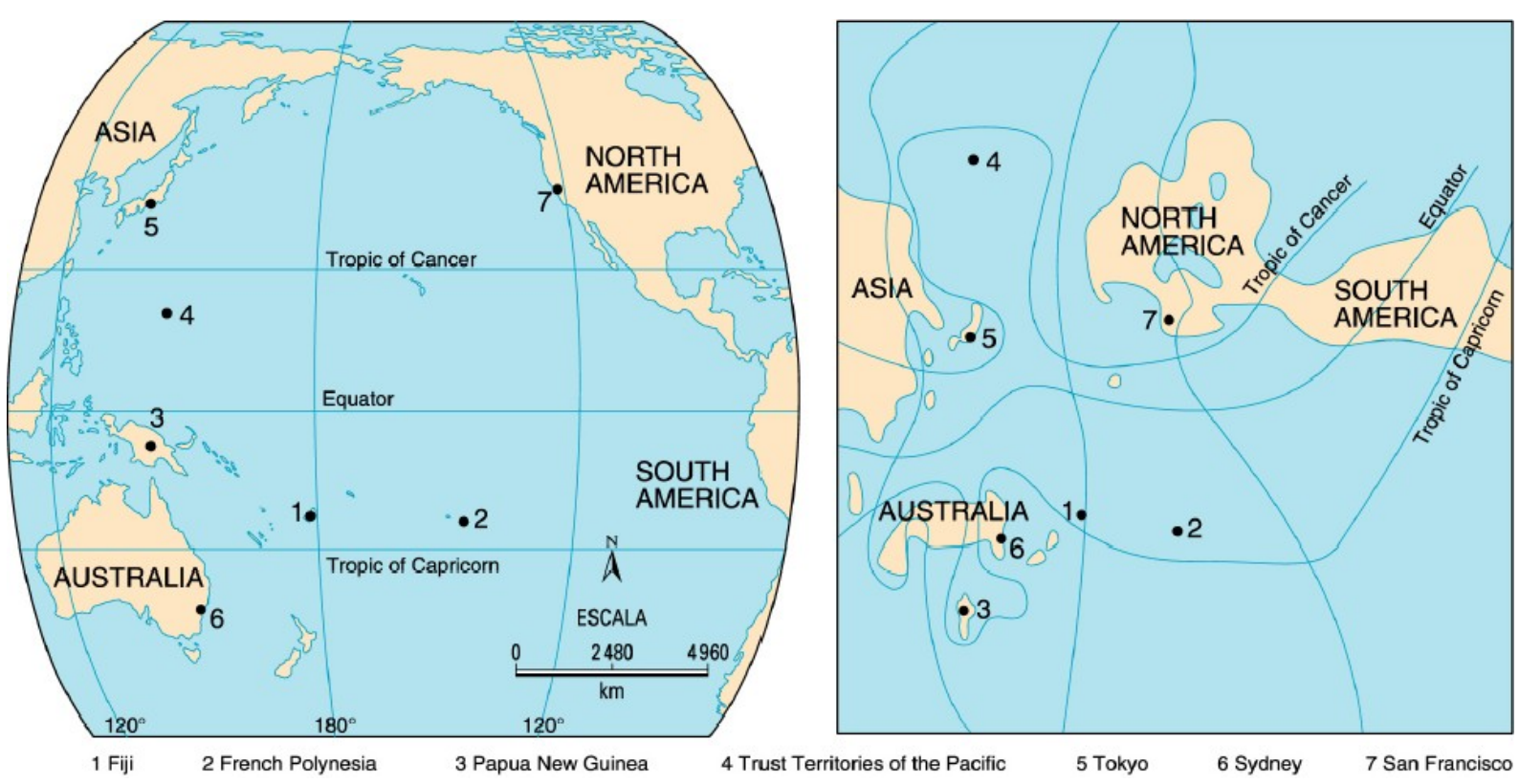

* Baseado no tempo relativo de deslocamento por linhas aéreas comerciais em 1975.

Fonte: Leyshon (1995, p. 18).

b)
Harvey (1980, p. 5) corrobora isso ao afirmar que: "O movimento de pessoas, bens, serviços e informações tem lugar num espaço relativo, porque é preciso dinheiro, tempo, energia etc., para ultrapassar o atrito da distância.". Smith (1988, p. 130) desvenda claramente esse processo: "Não é Einstein, nem a Física, nem a Filosofia que, em última instância, determina a relatividade do espaço geográfico, mas é o processo de acumulação de capital.”. Ao que Harvey (1980, p. 5) acrescenta: "não há respostas filosóficas para as questões filosóficas que surgem sobre a natureza do espaço - as respostas estão na prática humana".

O geógrafo norte-americano, tentando apreender o mesmo fenômeno resultante do avanço técnico, fala em "compressão do tempo-espaço". Mas mesmo ele pode nos induzir a confusões, como espero demonstrar.

Pretendo indicar com essa expressão processos que revolucionam as qualidades objetivas do espaço e do tempo a ponto de nos forçarem a alterar, às vezes radicalmente, o modo como representamos o mundo para nós mesmos. Uso a palavra "compressão" por haver fortes indícios de que a história do capitalismo tem se caracterizado pela aceleração do ritmo da vida, ao mesmo tempo em que venceu as 
barreiras espaciais em tal grau que por vezes o mundo parece encolher sobre nós. (HARVEY, 1993, 217).

Para ilustrar essa sua pretensão, David Harvey mostra a imagem a seguir (figura 5):

\section{Figura 5. 0 encolhimento do mapa-múndi ${ }^{\star}$}

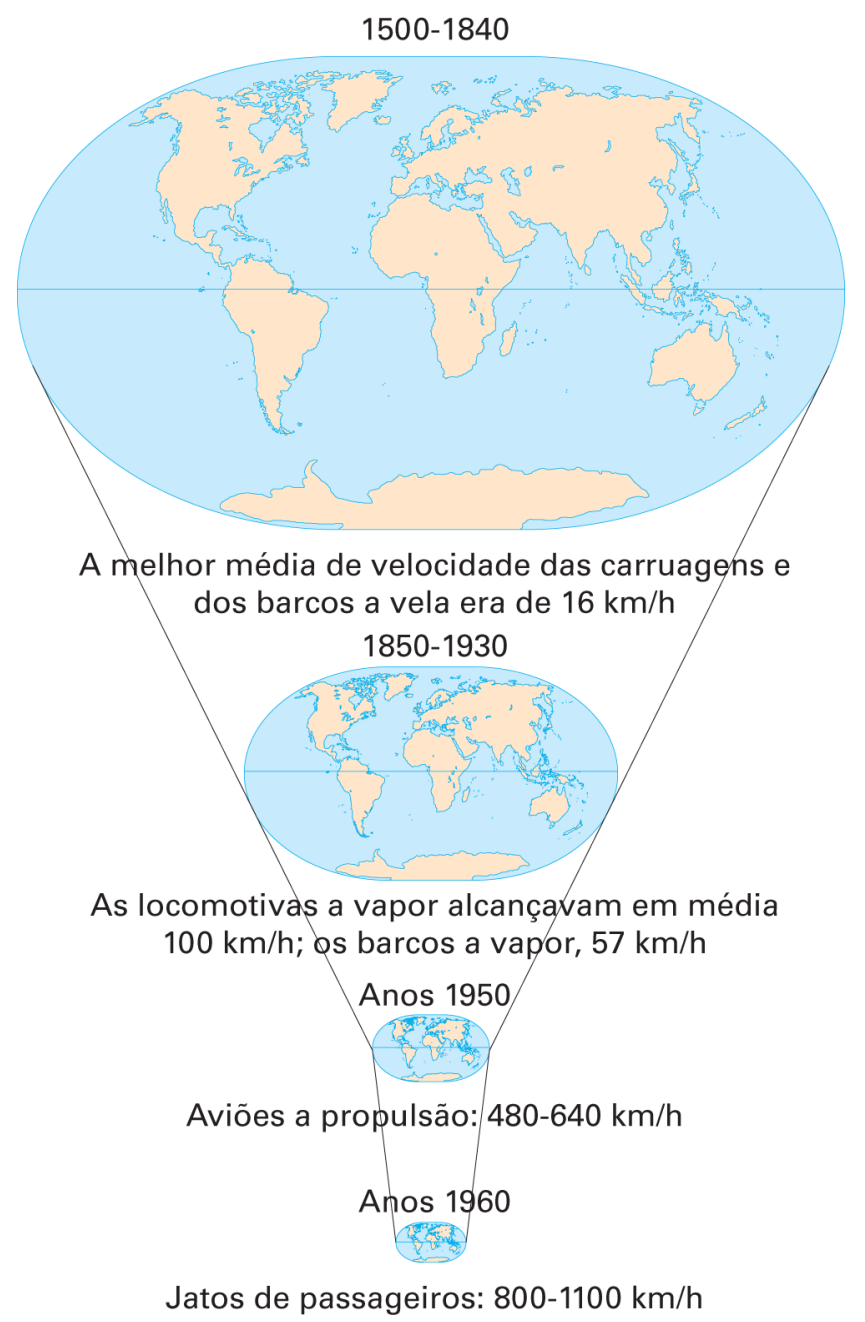

*Graças a inovações nos transportes que "aniquilam o espaço por meio do tempo".

Fonte: Harvey (1993, p. 220).

O problema é que a idéia de que "o espaço é aniquilado por meio do tempo", de que ocorre a "compressão do tempo-espaço", ilustrada pela imagem acima, nos induz a pensar que o mundo "se encolhe" por igual, quando não é isso o que ocorre. Como vimos na figura 4, o "encolhimento" é desigual tanto para os lugares quanto para as pessoas, mesmo para muitas das que vivem nos lugares que 
mais convergem no espaço-tempo. Também induz muitos a tomar a distância - uma propriedade do espaço geométrico - como se fosse o espaço e daí concluir erroneamente que o espaço geográfico está encolhendo. $O$ encolhimento das distâncias, como resultado da maior densidade de objetos técnico-informacionais no espaço terrestre, faz com que as possibilidades, as oportunidades aumentem, especialmente para aqueles agentes mais bem preparados para produzir espaço e se apropriar dele. Com isso, poderíamos dizer que o espaço geográfico produzido pelo homem, como locus de possibilidades e oportunidades - sociais, econômicas, culturais etc. -, ao invés de encolher, está ampliando.

Assim, considero muito oportuna a proposta de Castells (2000, p. 403): "Ao contrário da maioria das teorias sociais clássicas, que supõem o domínio do espaço pelo tempo, proponho a hipótese de que o espaço organiza o tempo na sociedade em rede.". Mas isso só é válido se pensarmos o espaço como um produto da sociedade.

Por isso não faz sentido buscar a noção de espaço na Filosofia ou na Física; o conceito de espaço geográfico deve ser buscado na prática dos homens sobre o território, na dialética sócio-espacial. A manutenção do adjetivo "geográfico" é importante para delimitar a região do conhecimento, o campo disciplinar em que o conceito de "espaço" está sendo definido e operacionalizado. Assim, é necessária essa demarcação ontológica, ou mais especificamente ôntica.

Antes de avançar nesse debate, é preciso apontar mais algumas contradições nas Orientações Curriculares para o Ensino Médio quanto à utilização dos conceitos e categorias. Como vimos no trecho transcrito anteriormente, na página 221, no corpo do texto as OCEM (BRASIL, 2006, p. 50) definem "espaço e tempo" como "categorias". Entretanto, num quadro do mesmo documento (BRASIL, 2006, p. 53), "espaço e tempo" aparecem como "conceitos", como "dimensões materiais da vida humana", como "expressões concretizadas da sociedade" (ver quadro 13). 


\section{Quadro 13. Conceitos estruturantes e articulações*: OCEM}

\begin{tabular}{|c|c|}
\hline CONCEITOS & ARTICULAÇŌES ${ }^{* *}$ \\
\hline $\begin{array}{l}\text { ESPAÇO E } \\
\text { TEMPO }\end{array}$ & $\begin{array}{l}\text { - Principais dimensões materiais da vida humana. } \\
\text { - Expressões concretizadas da sociedade. } \\
\text { - Condicionam as formas e os processos de apropriação dos terri- } \\
\text { tórios. } \\
\text { - Expressam-se no cotidiano caracterizando os lugares e definin- } \\
\text { do e redefinindo as localidades e regiōes. }\end{array}$ \\
\hline SOCIEDADE & $\begin{array}{l}\text { - Consideradas as relações permeadas pelo poder, apropria-se } \\
\text { dos territórios (ou de espaços específicos) e define as organi- } \\
\text { zação do espaço geográfico em suas diferentes manifestações: } \\
\text { território, região, lugar, etc. } \\
\text { - Os processos sociais redimensionam os fenômenos naturais, o } \\
\text { espaço e o tempo. }\end{array}$ \\
\hline LUGAR & $\begin{array}{l}\text { - Manifestação das identidades dos grupos sociais e das pessoas. } \\
\text { - Noção e sentimento de pertencimento a certos territórios. } \\
\text { - Concretização das relações sociais vertical e horizontalmente. }\end{array}$ \\
\hline PAISAGEM & $\begin{array}{l}\text { - Expressão da concretização dos lugares, das diferentes dimen- } \\
\text { sões constituintes do espaço geográfico. Pelas mesmas razões já } \\
\text { apontadas, não limitaria a paisagem apenas ao lugar. } \\
\text { - Permite a caracterização de espaços regionais e territórios con- } \\
\text { siderando a horizontalidade dos fenômenos. }\end{array}$ \\
\hline REGIÃO & $\begin{array}{l}\text { - Região se articula com território, natureza e sociedade quando } \\
\text { essas dimensöes são consideradas em diferentes escalas de } \\
\text { análise. } \\
\text { - Permite a apreensão das diferenças e particularidades no espa- } \\
\text { ço geográfico. }\end{array}$ \\
\hline TERRITORIO & $\begin{array}{l}\text { - O território é o espaço apropriado. } \\
\text { - Base da região. } \\
\text { - Determinação das localizações dos recursos naturais e das rela- } \\
\text { çöes de poder. } \\
\text { - A constituição cotidiana de territórios tem como base, as rela- } \\
\text { ções de poder e de identidade de diferentes grupos sociais que } \\
\text { os integram, por isso eles estão inter-relacionados com concei- } \\
\text { tos de lugar e região. }\end{array}$ \\
\hline
\end{tabular}

* Este quadro foi elaborado tendo como referência inicial o quadro inserido no documento dos PCN + Ensino Médio (Ciências Humanas e suas tecnologias, p. 56), com a incorporação de outras formas de entendimento dos conceitos.

** Nesta coluna há sugestões de algumas articulações possíveis entre os conceitos. A finalidade é demonstrar que os conceitos não têm limites definidos e deixar o professor com liberdade de utilizar as mais diferentes combinações possíveis.

Fonte: Brasil (2006, p. 53). 
No trecho já transcrito anteriormente - "Os conceitos cartográficos (escala, legenda, alfabeto cartográfico) e os geográficos (localização, natureza, sociedade, paisagem, região, território e lugar) [...]" (BRASIL, 2006, p. 50) -, "natureza" aparece como conceito geográfico, mas não consta do quadro 13. Sem contar que, considerando a definição de conceito dada pelo próprio documento, "localização" não é propriamente um conceito da Geografia e sim um procedimento analítico da realidade. Localizar um fenômeno no espaço é fundamental para apreender suas relações, e isso, evidentemente, não é de interesse apenas da Geografia. Na Economia, por exemplo, há uma "teoria da localização", desenvolvida com base nos estudos iniciais de Von Thünen, que criou modelos de localização industrial visando à maximização dos lucros (SANDRONI, 2001).

As contradições continuam: na introdução do capítulo 2 das OCEM, que trata do "conhecimento de Geografia", é dito que:

[...] o ensino de Geografia deve fundamentar-se em um corpo teórico-metodológico baseado nos conceitos de natureza, paisagem, espaço, território, região, rede, lugar e ambiente, incorporando também dimensões de análise que contemplam tempo, cultura e sociedade, poder e relações econômicas e sociais e tendo como referência os pressupostos da Geografia como ciência que estuda as formas, os processos, as dinâmicas dos fenômenos que se desenvolvem por meio das relações entre a sociedade e a natureza, constituindo o espaço geográfico. (BRASIL, 2006, p. 43).

Aqui "espaço" aparece como conceito-base, porém "tempo" não. "Sociedade" também não tem a centralidade que sugere o documento em outras passagens, incluindo a lista de conceitos-chave (BRASIL, 2006, p. 53). No trecho acima foi a primeira vez que se fez menção ao conceito de "natureza", que depois apareceria novamente na página 50 das OCEM. Acima, ainda se faz menção ao conceito de "rede", que constava da lista de conceitos-chave dos PCNEM originais. Entretanto, nem um nem outro constam da lista de conceitos-chave das OCEM. O conceito de "ambiente" aparece apenas na passagem transcrita acima e em nenhum outro lugar. Enfim, fica-se em dúvida sobre quais são efetivamente os conceitos estruturantes da Geografia de acordo com a proposta do documento. Se tomarmos como referência a lista da página 53 das OCEM (ver quadro 13), então inegavelmente está faltando o conceito de "natureza". Como entender as "relações entre a sociedade e a natureza" sem trabalhar com esse último conceito, ainda mais 
que o documento abdicou da noção de "espaço geográfico", que contém aqueles dois conceitos?

Como o documento preliminar das Orientações Curriculares para o Ensino Médio (BRASIL, 2004a) critica o conceito de "espaço geográfico" adotado nos PCNEM (BRASIL, 1999, 2002a), porque supostamente negligenciaria a "sociedade" como objeto de estudo da Geografia (a sociedade não seria objeto de estudo da Sociologia?), ele não consta da lista dos conceitos estruturantes na proposta final das OCEM (BRASIL, 2006, p. 53), embora apareça ao longo do texto, como no trecho transcrito acima. Como seus autores concluíram que antes, no PCNEM, a sociedade teria ficado negligenciada, procuraram dar destaque a esse conceito inserindo-o na lista do documento final das OCEM (ver quadro 13), o que só acentuou a separação entre sociedade e espaço geográfico. A "amputação" filosófica de que falou Smith (1988) permanece porque se depreende que a sociedade, na perspectiva da Geografia, pode ser analisada isolada do espaço produzido por ela.

Um acordo sobre o que são conceitos e categorias e com quais deles operar não é mesmo tarefa fácil, senão impossível. Armando Corrêa da Silva, por exemplo, distingue categorias filosóficas de categorias científicas e afirma que estas são mais concretas que aquelas. O problema é que, quando esse geógrafo brasileiro, falecido em 2000, listou o conjunto das categorias científicas da Geografia, não distinguiu o que é propriamente categoria do que é conceito. Para ele: "As categorias fundamentais do conhecimento geográfico são, entre outras, espaço, lugar, área, região, território, habitat, paisagem e população, que definem o objeto da Geografia em seu relacionamento." (SILVA, 1986, p. 28-29). Em seu artigo As categorias como fundamentos do conhecimento geográfico, não menciona o termo conceito em nenhum momento. O que ele chama de "categorias", outros geógrafos chamam de "conceitos". Roberto Lobato Corrêa, por exemplo, chama espaço, lugar, região, território e paisagem de conceitos-chave da Geografia. No artigo Espaço, um conceito-chave da Geografia, depois de discutir o conceito de formação sócio-espacial, afirma: 
Nesta linha de raciocínio admitimos que a formação sócio-espacial possa ser considerada como uma meta-conceito, um paradigma, que contém e está contida nos conceitos-chave, de natureza operativa, de paisagem, região, espaço (organização espacial), lugar e território. (CORRÊA, 1995, p. 27).

Milton Santos também não é muito preciso na utilização dos termos. Em um trecho transcrito na página 210 , no qual se pode detectar a inspiração dos autores do PCNEM para a seleção dos conceitos-chave da Geografia, ele diz que, a partir da noção de espaço como um conjunto indissociável de sistemas de objetos e de sistemas de ações, é possível reconhecer suas categorias analíticas internas. Em seguida lista essas categorias: a paisagem, a configuração territorial, a divisão territorial do trabalho, o espaço produzido ou produtivo, as rugosidades e as formasconteúdo. (SANTOS, 1996a).

Aqui se mesclam conceitos e categorias. Por exemplo, o conceito de paisagem aparece como categoria analítica interna. Espaço produzido (ou produtivo, que não é a mesma coisa) também aparece como categoria analítica interna do conceito ${ }^{104}$ de espaço geográfico.

Antonio Carlos Robert Moraes afirma ser impossível uma "dialética do espaço" tanto quanto uma "dialética da natureza". Para ele, "dialética" serve exclusivamente para "a análise de fenômenos e processos sociais, pois pressupõe um movimento objetivado por ações conscientes" (MORAES, 2000, p. 13). Desse modo, vê o espaço como um conceito reificado, por isso defende que mais apropriado para apreender a relação sociedade-espaço é o conceito de território:

Este resulta da relação de uma sociedade específica com seu espaço, sendo objetivado pelo intercâmbio contínuo que humaniza esse âmbito espacial, materializando sincronicamente as formas de sociabilidade nela reinantes numa paisagem e numa estrutura territorial. (MORAES, 2000, p. 38).

Entretanto, aceita, concordando com Milton Santos, que, embora o espaço não seja sujeito, influencia as ações sociais e as explica. Corrobora, na própria definição de território, a relação sociedade-espaço. Assim, não é possível uma "dialética do espaço", muito menos uma "dialética da natureza", mas sim uma “dialética sócio-espacial”, como falam Correa (1995), Harvey (1980), Santos (1996a), Smith (1988) e Soja (1993).

\footnotetext{
104 Em fala em "noção", que se pode inferir, foi utilizada como sinônimo de conceito.
} 
Pascal Baud e colegas comentam que a palavra "espaço" é polissêmica por excelência e que é utilizada com diferentes sentidos por geógrafos, astrônomos, filósofos ou matemáticos (acrescentaria: físicos, psicólogos, arquitetos etc.). Em seguida, afirmam que, para evitar tal polissemia, "muitos geógrafos propuseram a criação da expressão 'espaço geográfico'. Mas ela abrange sentidos diferentes, visto que os geógrafos não têm todos a mesma concepção da sua disciplina". (BAUD et al., 1999, p. 104, grifo do autor).

De fato, como vimos, não é mesmo uma tarefa fácil chegar a um acordo quanto aos conceitos e as categorias da Geografia. Talvez o acordo seja mesmo impossível ou nem mesmo necessário, "visto que os geógrafos não têm todos a mesma concepção de sua disciplina”. A pluralidade teórico-metodológica enriquece a Geografia. Entretanto, isso não quer dizer que o exercício da crítica e a busca de consistência e coerência não sejam necessários. As novas propostas são bemvindas, necessárias e é por meio da crítica que o conhecimento avança. Assim, faço minhas as palavras finais de Antonio Carlos Robert Moraes, no posfácio à $20^{\text {a }}$ edição de seu livro, Geografia: pequena história crítica, manual que contribuiu para a formação de algumas gerações de geógrafos:

Vivemos no campo disciplinar uma época de pluralidade de métodos, o que é altamente salutar para o avanço do conhecimento desde que as distintas orientações estimulem a explicitação dos posicionamentos assumidos e 0 debate intermetodológico. (MORAES, 2005, p. 143).

Considerando toda a explanação anterior, defendo que o conceito de espaço geográfico continue a ser utilizado. Mas aqui o espaço deve ser pensando como resultado da produção dos homens vivendo em sociedade. Deve ser levado em conta que o conceito de espaço geográfico é mais concreto que a categoria espaço, portanto tem maior capacidade de apreender a realidade. Além disso, contém o espaço (absoluto - x, y, z - e relativo) e o tempo (físico e histórico) como categorias empiricizadas. E ainda, pensado como meta-conceito, contém os conceitos de sociedade e de natureza, que precisam ser considerados em relação e nunca isolados do espaço produzido. Como já disse Smith (1988, p. 123): "Com a 'produção do espaço', a prática humana e o espaço são integrados no nível do 'próprio' conceito de espaço.". Para compreender o espaço geográfico, é necessário 
lançar mão de conceitos que analisam suas várias dimensões, como é o caso de lugar, território e região, além, evidentemente, de paisagem, que é sua face visível.

Isso ilustra as dificuldades da implantação de uma reforma curricular, porque, como foi dito, o currículo, além de expressar, molda subjetividades sociais, expõe conflitos políticos e ideológicos - da sociedade - e expressa divergências epistemológicas e teórico-metodológicas - dos campos disciplinares. As próprias OCEM apontam essa dificuldade quando afirmam que "a seleção dos conceitos pode ser marcada por recortes culturais, sociais e históricos, tendo por base as discussões acadêmicas, os resultados das investigações, as contribuições dos discursos políticos e sociais, os meios de comunicação e as práticas sociais". (BRASIL, 2006, p. 53). Como podemos perceber, as contradições acerca dos conceitos e categorias selecionados estão mais ligadas às "discussões acadêmicas", como diz o documento do MEC, à pluralidade de concepções teórico-metodológicas existentes no campo disciplinar da Geografia. 


\section{A Geografia no ensino SeCundário espanhol}

Para compreender a situação atual da Geografia no currículo do ensino secundário espanhol, é necessário estudar os Decretos Reais de enseñanzas mínimas ${ }^{105}$, tanto da Educación Secundaria Obligatória (ESO) quanto do "bachillerato", desde a aprovação da Ley de Ordenación General del Sistema Educativo (LOGSE) até a atual Ley Orgânica de Educación (LOE). Tanto na ESO quanto no "bachillerato", a $L O E$ herdou, em linhas gerais, o currículo de Geografia da LOGSE, que foi responsável pela promoção das mais profundas mudanças no sistema educativo espanhol desde a Ley General de Educación (LGE). Entretanto, é importante retomar brevemente, apenas a título de comparação, como era o ensino de Geografia no âmbito da $L G E$.

\section{Antecedentes: a Geografia na LGE}

A Geografia tem uma longa presença no sistema de ensino espanhol. Ela está no currículo como disciplina independente desde a Ley Moyano, de 1857. Entretanto, isso mudou com a aprovação da Ley General de Educación (LGE), em 1970. Nas palavras de Capel, Luis e Urtega (1984, p. 30):

La aplicación de la Ley General de Educación en la Enseñanza Básica (6-14 anos) entrañaba una profunda ruptura con el estatuto de la geografía de los programas que se configuraron con la Ley Moyano de 1857. De hecho, desparecía ésta como materia independiente de enseñanza, quedando integrada en áreas de conocimiento más amplias.

A partir da $L G E$, a Geografia, nos oito anos da Educación General Básica $(E G B)$, passa a fazer parte da área interdisciplinar de Ciências Sociais ao lado de História e Educação Cívica. Embora houvesse assuntos de Geografia em todos os

105 Referem-se aos conteúdos mínimos de cada uma das disciplinas escolares do ensino primário, secundário obrigatório e "bachillerato", definidos pelo governo central e que devem ser respeitados pelas Comunidades Autônomas ao elaborarem seus respectivos currículos. 
anos, seu temário aparecia mais nitidamente no Ciclo Superior da EGB (10-13 anos). No Bachillerato Unificado Polivalente (BUP) constava em dois dos três anos desse antigo curso secundário: no $2^{\circ}$ BUP como disciplina independente Geografía Humana y Económica del Mundo Actual - e no $3^{\circ}$ BUP com História Geografía e Historia de España y los Países Hispánicos.

No antigo Curso de Orientación Universitária (COU), a Geografia foi oferecida como matéria optativa, como parte do bloco de matérias de Letras ou Humanidades, entre 1971-1975 - Geografia Humana - e entre 1975-1978 Geografia Econômica.

Segundo avaliação de Capel, Luis e Urteaga (1984), a partir de 1970, de acordo com previsões da $L G E$, a Geografia deveria ter desaparecido do currículo da educação básica: os conteúdos da Geografia Física seriam integrados em Ciências da Natureza e os da Geografia Humana, em Ciências Sociais. Entretanto, na prática isso não ocorreu, porque os programas de Ciências Sociais se limitaram a justapor os conteúdos de Geografia e História, até então disciplinas independentes. Além disso, os técnicos do Ministério da Educação responsáveis pela elaboração dos programas "no dudaron en incluir dentro del área de "Ciencias Sociales" una serie de lecciones sobre geografía física". (CAPEL; LUIS; URTEAGA, 1984, p. 32). Os manuais didáticos seguiram essas diretrizes. Para exemplificar, os três autores mencionam um livro, cujo título é Sociedad, no qual 50\% dos temas são de Geografia Física. Creditam isso à inércia dos geógrafos, ao interesse do mercado editorial e especialmente à condescendência das autoridades educativas que "han permitido que las antíguas asignaturas, con ligero maquillaje y algún recorte, sigan enseñándose en la actualidad bajo nuevos nombres". (CAPEL; LUIS; URTEAGA, 1984, p. 33).

Na Espanha, a Geografia tem, como no Brasil ou na França, uma longa tradição de ensino mnemônico e corográfico. Também nesse país ibérico, historicamente essa disciplina cumpriu o papel ideológico denunciado por Lacoste (1988) ao criticar a "Geografia dos professores". O texto a seguir, extraído do livro Didáctica de la Geografía de Xosé Manuel Souto González, ilustra essa tradição: 
Seguramente más de uno recuerda sus clases de geografía como el estudio memorístico de nombres de ríos, montes, islas, capitales de países. Y también recuerda el haber calcado numerosos mapas, donde se colocaban esos nombres. $E$ incluso es posible que nos acordemos de aquellos viejos mapas murales, donde teníamos que señalar aquellos nombres. El nombre de los lugares caracterizó, en muchos momentos, a la didáctica de la geografía. (SOUTO GONZÁLEZ, 1999, p. 25).

Seguindo o mesmo itinerário que outros países vizinhos do continente europeu - o mesmo seguido pelo Brasil sob influência daqueles países, especialmente da França -, o ensino de Geografia começou a mudar a partir dos anos 1970, sob o marco legal da LGE. Passou-se de uma Geografia regional corográfica a outra, que enfatizava os diversos ramos da Geografia geral (população, agrária, urbana etc.) e especialmente os aspectos socioeconômicos, sobretudo no Bachillerato Unificado Polivalente (CAPEL, 1997). Segundo Guijarro Gutiérrez (1997), nessa época o ensino da disciplina, assim como o de História, transitou do "facticismo" - havia uma justaposição de fatos e datas no ensino dessas disciplinas - ao "conceptismo", abrindo possibilidades para considerações mais atentas dos elementos estruturais da realidade social, passada e presente.

Se, durante o regime de Francisco Franco, a Geografia tinha o papel de enaltecer a pátria e a coesão territorial da Espanha, na transição para a democracia parlamentar, com o processo de descentralização político-administrativo e educativo, em grande medida passa a ser instrumentalizada pelo nacionalismo de algumas Comunidades Autônomas, especialmente o País Basco e a Catalunha. Passa-se a valorizar um ensino de Geografia mais vinculado a esses territórios, uma educação patriótica voltada para a consolidação da identidade nacional/regional. Como afirma Souto González (1999, p. 43), "se intenta crear 'patria' a través de la educación geográfica", a "patria chica"106", como diz o mesmo autor em outro texto (2003). Aí está um bom exemplo do que Moraes (2000) chama de "ideologias geográficas" na construção do território. Romero Morante e Luis Gómez (2008, p. 11) denunciam que a "pedagogia do entorno", que então começava a se disseminar no ensino de Geografia na Espanha como se fosse uma novidade, contribuiu, muitas vezes, para esse fim ideológico:

\footnotetext{
106 "Pátria pequena", em referência às Comunidades Autônomas, ao fato de que o poder político descentralizado
} passa a utilizar o "saber geográfico" para criar identidades territoriais frente ao poder central. 
El frecuente aprovechamiento de esta solución didáctica para crear o reforzar sentimientos de identidad regional o nacional, como ha ocurrido en la España de las Autonomias, acostumbra a evocar una concepción comunitarista de la organización política vigente o soñada, justificada en la existencia previa de un "pueblo" o de algún tipo de comunión cultural.

Mudanças mais significativas no ensino de Geografia ocorreriam após a abertura política, que tem como marco a aprovação da Constituição de 1978. Nos anos 1980 e início dos 1990, ocorrem mudanças sob a influência dos diversos grupos de renovação pedagógica - Ires (Andaluzia), Cronos (Salamanca), Ínsula Barataria (Aragão), Asklepios (Cantábria), Gea-Clío (Valência) etc. -, apesar de suas diferenças em termos epistemológicos e pedagógicos e também de suas limitações estruturais ${ }^{107}$. Muito contribuiu também para essas mudanças 0 movimento de renovação crítica da Geografia universitária, tendo como um dos principais protagonistas na Espanha o professor Horacio Capel, da Universidade de Barcelona. Deve ser lembrado que ele foi responsável, com Alberto Luis e Luis Urteaga, pela elaboração de uma proposta concreta para o currículo de Geografia no contexto da reforma educativa que estava se gestando nos anos 1980 (CAPEL; LUIS; URTEAGA, 1984).

Entretanto, as mudanças mais significativas viriam com a aprovação da LOGSE, sob o governo do Partido Socialista Obrero Español (PSOE). A aprovação dessa lei reformista de caráter global foi seguida pelos decretos de ensenãnzas mínimas, para a educação primária, a secundária obrigatória (ESO) e o bachillerato. Aqui nos interessa analisar o currículo da ESO e do bachillerato.

107 Ao estudar os grupos Insula Barataria, Cronos e IRES, Alfonso Guijarro Gutiérrez conclui que estes não avançaram mais na renovação do ensino de Geografia, entre outros motivos, porque tentaram compatibilizar uma proposta reformista em termos pedagógicos com a consideração dos temas propostos nos decretos de enseñanzas mínimas do Ministério da Educação. Essa empreitada redundou paradoxalmente em programas muito extensos, enciclopédicos, incompatíveis com uma didática ativa (GUIJARRO GUTIÉRREZ, 1997). Tratava-se de uma renovação sob o controle do governo. Como disse Capel (1997): "Si, por un lado, han desarrollado propuestas de enseñanza activa, por otro se han mantenido fieles a las directrices curriculares aprobadas por el Ministerio, lo que por otra parte era condición imprescindible para poder optar a los concursos de producción de materiales pedagógicos convocados por las autoridades educativas.". Como membro do grupo Asklepios, Gutiérrez procurou desenvolver sua própria proposta curricular centrada em torno de problemas atuais relevantes. Entretanto, não é tarefa fácil definir um conjunto coerente e bem organizado de problemas e ainda mais conciliá-los, como propõe o autor, com a redução de conteúdos, de forma que o conhecimento desenvolvido se torne significativo para os estudantes. 


\title{
A LOGSE e as enseñanzas mínimas
}

\author{
Educación SeCundaria ObLigatoria
}

As enseñanzas mínimas para a educación secundaria obligatoria (ESO) foram estabelecidas pelo Decreto Real 1007, aprovado em 14 de junho de 1991. Trata-se de uma lei complementar que regula a modalidade curricular da reforma implementada pela Ley de Ordenación General del Sistema Educativo (LOGSE), de 1990. Esse decreto definiu o currículo mínimo para toda a Espanha com a justificativa de assegurar uma formação comum aos alunos de todo o território nacional, a validade dos títulos correspondentes e a coerência de aprendizagem em caso de mudança de uma Comunidade Autônoma para outra. É prerrogativa das Comunidades Autônomas definir o currículo, conforme consta do artigo 4.2 da LOGSE (ver abaixo) e do preâmbulo do decreto 1007; entretanto, ao fazerem isso, devem levar em conta as enseñanzas mínimas fixadas pelo governo central. Conforme consta também no artigo 4.2 da LOGSE e no preâmbulo do decreto 1007, os conteúdos básicos das enseñanzas mínimas devem corresponder a no máximo $65 \%$ do horário escolar das Comunidades Autônomas que tenham o espanhol como língua oficial e a $55 \%$ daquelas que tenham uma língua co-oficial diferente do castelhano ${ }^{108}$.

\begin{abstract}
Artículo 4
2. El Gobierno fijará, en relación con los objetivos, expresados en términos de capacidades, contenidos y criterios de evaluación de currículo, los aspectos básicos de éste que constituirán las enseñanzas mínimas, con el fin de garantizar una formación común de todos los alumnos y la validez de los títulos correspondientes. Los contenidos básicos de las enseñanzas mínimas en ningún caso requerirán más del 55 por 100 de los horarios escolares para las Comunidades Autónomas que tengan lengua oficial distinta del castellano, y del 65 por 100 para aquellas que no la tengan. (ESPAÑA, 1990, p. 28930).
\end{abstract}

\footnotetext{
108 A língua espanhola, em virtude das suscetibilidades nacionalistas, dentro da Espanha é chamada de castelhano (castillano ou castellano), já que teve sua origem na região de Castela (Castilla).
} 
Os conteúdos das enseñanzas mínimas para a área de Ciencias Sociais, Geografia e História da ESO, segundo o Decreto Real 1007/1991, estão divididos em conceitos, procedimentos e atitudes ${ }^{109}$.

Diferentemente da época da $L G E$, agora o título da área faz jus a seu nome, porque, embora a Geografia e a História tenham destaque, há conteúdos de outras Ciências Sociais: Economia, Sociologia, História da Arte e Política. De acordo com um informe da Asociación de Geógrafos Españoles (AGE), o decreto 1007 concede uma importância destacada à Geografia e à História em relação às outras disciplinas da área de Ciências Sociais "debido fundamentalmente al peso específico que por tradición han tenido estas disciplinas como ciencias encargadas del conocimiento de la sociedad y - lo que es más importante - a su capacidad estructuradora de los hechos sociales". (ASOCIACIÓN DE GEÓGRAFOS ESPAÑOLES, 2000, p. 14).

Ao longo dos quatro anos da ESO, a área de Ciências Sociais, Geografia e História deveria desenvolver os conteúdos conceituais dos quatro blocos a seguir (aparecem detalhadamente no anexo $\mathrm{E}$ ):
1. SOCIEDAD Y TERRITORIO
Conceptos
1. Iniciación a los métodos geográficos.
2. El medio ambiente y su conservación.
3. La población y los recursos.
4. Las actividades económicas e el espacio geográfico.
5. El espacio urbano.
6. Espacio y poder político.

\section{Sociedades históricAs Y CAMBIO EN EL TIEMPO Conceptos \\ 1. Iniciación a los métodos históricos. \\ 2. Sociedades prehistóricas, primeras civilizaciones y antigüedad clásica. \\ 3. Las sociedades medievales. \\ 4. Las sociedades de Antiguo Régimen en la época moderna. \\ 5. Alguna sociedad destaca de ámbito no europeo durante las Edades Media y Moderna. \\ 6. Cambio y revolución en la Edad Contemporánea. \\ 7. Sociedades y culturas diversas.}

\section{El MUNDO ACTUAL}

109 No anexo E, pode-ser ver o trecho deste documento em que são listados os conteúdos conceituais, procedimentais e atitudinais da área de Ciências Sociais, Geografia e História. 
Conceptos

1. Transformaciones y desequilibrios en el mundo actual.

2. La organización económica y el mundo del trabajo.

3. Poder político y participación ciudadana.

4. Arte y cultura en el mundo actual.

4. LA VIDA MORAL Y LA REFLEXIÓN ÉTICA ${ }^{110}$

Conceptos

1. La génesis de los valores morales: su historicidad y universalidad.

2. Autonomía y heteronomía moral.

3. Principales teorías éticas.

4. Principales problemas morales de nuestro tiempo (violencia social, consumismo, marginalidad y discriminación).

5. Algunos proyectos éticos contemporáneos (derechos humanos, pacifismo, feminismo, ecologismo).

6. La autoridad y su legitimación. Las leyes: necesidad de obediencia y desobediencia legitima.

7. La religión como hecho individual y social. (ESPAÑA, 1991b, p. 41-44).

Como se percebe pela lista acima, apenas o primeiro bloco é reservado exclusivamente ao temário tradicionalmente tratado pela Geografia. O segundo é dedicado à História, o terceiro contempla temas de Economia, Política, Cultura e Arte, abordados tanto pela História quanto pela Geografia (especialmente os três primeiros), e o quarto bloco contempla temas próprios de Filosofia, Sociologia e Política.

O título da área - Ciências Sociais, Geografia e História - foi contemplado na inclusão dessas disciplinas e, teoricamente, seu caráter interdisciplinar foi assegurado. Pelo menos o documento propõe isso:

El tratamiento educativo apropiado para la inclusión de varias disciplinas en una sola área no es la mera yuxtaposición de las mismas, ni tampoco una globalización en la que se desdibuje la naturaleza específica de cada una de ellas; el planteamiento curricular adecuado está en una posición equilibrada entre ambos extremos, subrayando las relaciones y rasgos comunes de las disciplinas tanto como el carácter específico de las mismas. (ESPAÑA, 1991b, p. 41).

O decreto das enseñanzas mínimas buscava garantir uma certa flexibilidade para as escolas organizarem seu currículo, como se depreende do trecho a seguir:

110 "Este bloque se impartirá en el cuarto curso". 
Al establecer las enseñanzas mínimas comunes para todo el Estado, así como a la hora de fijar los distintos curriculums, se ha de procurar, en primer termino, que estos sean suficientemente amplios, abiertos e flexibles, de esta forma los profesores podrán elaborar proyectos y programaciones que desarrollen en la practica las virtualidades del currículo establecido adaptándolo a las características de los alumnos y a la realidad educativa de cada centro. (ESPAÑA, 1991a, p. 21193).

Aqui é interessante mencionar a definição de currículo constante das leis, que, segundo elas, não se trata apenas de uma lista de conteúdos a serem desenvolvidos no sistema escolar. Com base no artigo 4.1 da LOGSE, que entende por currículo "el conjunto de objetivos, contenidos, métodos pedagógicos y critérios de evaluación de cada uno de los niveles, etapas, ciclos, grados y modalidades del sistema educativo" (ESPAÑA, 1990, p. 28930), assim o define o Decreto Real 1007/1991 em seu artigo 4:

A los efectos de lo dispuesto en este real decreto se entiende por curriculum de la educacional secundaria obligatoria el conjunto de objetivos, contenidos, métodos pedagógicos y criterios de evaluación que ha de regular la practica docente en esta etapa. (ESPAÑA, 1991a, p. 21195).

Enfim, são definições técnicas, assépticas, nas quais não há conflito, mas controle do conhecimento e da prática docente. Vale a pena rever, nas páginas 20 e 21, as definições de currículo, sob uma perspectiva crítica, de Gimeno Sacristán (2000), Grundy (1994) e especialmente Kemmis (1998).

Os conteúdos duas páginas atrás deveriam ser desenvolvidos ao longo dos quatro anos da ESO, mas não havia a exigência de que o fossem da forma como estão listados: "Los contenidos no han de ser interpretados como unidades temáticas, ni, por tanto, necesariamente organizados tal y como aparecen en este real decreto". (ESPAÑA, 1991a, p. 21193). Em tese, as escolas e os professores tinham liberdade para organizá-los como melhor lhes aprouvesse. Na prática, no entanto, devido ao peso conformador do livro-texto, de modo geral, o primeiro ciclo ( $1^{\circ}$ e $2^{\circ}$ cursos) ficou reservado para abordagens interdisciplinares e o segundo ciclo para abordagens mais específicas, mais disciplinares. No $3^{\circ}$ curso foram desenvolvidos os conteúdos específicos da Geografia e no $4^{\circ}$ curso, os da História. Essa organização acabou se consolidando na nova mudança curricular de 2000 . (LÁZARO Y TORRES, 2001). 
A seguir, o estudo das enseñanzas mínimas da ESO decretadas sob o governo do Partido Popular (PP) permitirá uma comparação com a lista anterior e o aprofundamento da análise da educação secundária na Espanha.

\section{BACHILLERATO}

As enseñanzas mínimas para o bachillerato foram estabelecidas pelo Decreto Real 1178, aprovado em 2 de outubro de 1992. Nesse nível de ensino permanecia o mesmo critério válido para a ESO, previsto no artigo 4.2 da LOGSE: os conteúdos básicos das enseñanzas mínimas devem corresponder a $65 \%$ do horário escolar das Comunidades Autônomas que tenham o castelhano como língua oficial e a $55 \%$ das que não tenham.

Quanto à Geografia, sob a LOGSE, essa disciplina só era oferecida no $2^{\circ}$ curso de bachillerato. Eram quatro horas por semana na modalidade de Humanidades y Ciencias Sociales. Segundo o decreto de mínimos, no bachillerato:

La Geografía se ocupa específicamente del estudio del espacio y de los hechos sociales que se plasman en él. Sus fines fundamentales son el análisis y la comprensión de las características del espacio elaborado y organizado por una sociedad, estudiando para ello las localizaciones y distribuciones existentes y las causas, factores, procesos e interacciones que en dicha elaboración y organización se dan y sus consecuencias y proyecciones futuras. La Geografía estudia la compleja interacción del ser humano y la naturaleza, analizando las relaciones que se establecen entre ambos y sus consecuencias espaciales y medioambientales. Su finalidad básica es pensar y entender el espacio. (ESPAÑA, 1992b, p. 40, grifo nosso).

Pelo trecho acima, fica evidente que a relação sociedade-natureza era o objeto central de estudo da Geografia e que o conceito de espaço aparecia em destaque nesse processo - a finalidade básica da Geografia é pensar e entender o espaço. Entretanto, não havia preocupação com a definição desse conceito. A escala geográfica enfatizada no bachillerato era o território espanhol: "La Geografía que aquí se define es así una Geografía de España, de su unidad y diversidad, de sus dinámicas ecogeográficas, y de la utilización de sus recursos humanos y económicos." (ESPAÑA, 1992b, p. 40). No entanto, não perdia de vista o fato de que o país é parte da União Européia, membro de organismos internacionais e integrante 
do sistema mundial. Assim, conforme o decreto 1178/1992, os objetivos a serem atingidos pela Geografia no bachillerato passavam pelo estudo dos seguintes temas:

\section{Contenidos}

1. Aproximación al conocimiento geográfico.

Análisis de las distintas variables ecogeográficas que intervienen en los sistemas de organización territorial, y de su interacción. Lectura interpretativa y elaboración de información cartográfica, gráfica y estadística.

2. España: unidad y diversidad del espacio geográfico.

Factores de la unidad y la diversidad. Regiones y paisajes diferentes de la península e islas: contrastes físicos y sociales. La ordenación territorial: las Comunidades Autónomas. Procesos históricos de organización del espacio.

\section{Las dinámicas ecogeográficas.}

Los elementos del medio físico: relieve, clima, aguas, vegetación, suelos. Los grandes medios ecogeográficos y su dinámica. Tipos principales. La interacción naturaleza/sociedad. El papel de los factores políticos, socio-económicos, técnicos y culturales en la elaboración y transformación de los espacios geográficos.

\section{La desigual utilización de los recursos: espacio y actividad económica.}

Los recursos y su explotación. Repercusiones socioeconómicas y ambientales. Los espacios agrarios y forestales. Los recursos marinos; la actividad pesquera. Los espacios industriales. Fuentes de energía y aprovechamiento energético. Las actividades terciarias. La red de transportes y la vertebración territorial. Los espacios del ocio. El turismo.

\section{Población, sistema urbano y ordenación del territorio.}

La población española. Crecimiento demográfico y desigualdades espaciales. Procesos de urbanización y sistemas de ciudades.

Las disparidades regionales. Ordenación y desequilibrios territoriales.

\section{España en el mundo.}

La integración en un sistema económico planetario. Los grandes ejes mundiales. Europa: la construcción de la Comunidad Europea. Conflictos y desigualdades. La Comunidad Europea y España ante las relaciones norte-sur. España y la configuración de un espacio iberoamericano. Perspectivas geoestratégicas de España en el mundo. (ESPAÑA, 1992b, p. 41).

A seguir, o estudo das enseñanzas mínimas do bachillerato decretadas sob o governo do $P P$ permitirá uma comparação com a lista acima e o aprofundamento da análise da educação secundária pós-obrigatória na Espanha.

\section{As enseñanzas mínimas sob o governo dos Populares}


Com a chegada do Partido Popular (PP) ao governo em 1996, teve início um processo de crítica e revisão da LOGSE que culminaria na aprovação de uma nova reforma educacional, a Ley de Calidad de la Educación (LOCE), em 2002. Antes disso, porém, o governo foi mudando o que era possível no sistema de ensino. Em seu primeiro mandato o governo dos populares tinha limitações para alterar as leis educacionais herdadas dos socialistas, já que não tinha a maioria no Congresso dos Deputados e no Senado. O PP só obteve a maioria parlamentar nas eleições de 12 de março de 2000. Neste contexto de disputas político-ideológicas bipartidaristas, em 29 de dezembro de 2000 foi aprovado o Decreto Real 3473, modificando o Decreto Real 1007/1991. Mas, essa mudança ainda se deu sob o marco regulatório da LOGSE, especialmente de seu artigo 4.2.

Uma primeira mudança em relação ao decreto anterior foi a definição dos conteúdos da ESO de forma mais rígida, divididos por cursos, como se depreende do trecho a seguir:

Finalmente, la necesidad de facilitar la movilidad de los alumnos por todo el territorio nacional y la validez del título a que dan lugar estos estudios, hacen precisa una mayor concreción de los objetivos y contenidos básicos comunes, lo que lleva a una nueva definición por cursos del currículo escolar básico de la educación secundaria obligatoria. (ESPAÑA, 2001a, p. 1810).

Para Souto González (2003), isso revela uma falta de confiança nos professores, como, aliás, já tinha ocorrido em outros momentos da história escolar espanhola. Ou seja, o tecnicismo, a busca de controle sobre o currículo, aumentou em comparação com o decreto de mínimos anterior.

Como fica evidente pelo trecho a seguir - primeiro parágrafo da introdução aos conteúdos da área - houve uma valorização das disciplinas Geografia e História em detrimento das outras Ciências Sociais, embora haja alguns conteúdos de Economia e Política diluídos nos temas geográficos do $2^{\circ}$ curso e temas de Filosofia no bloco de História do $4^{\circ}$ curso. Houve uma clara valorização das categorias espaço e tempo:

El conocimiento de la sociedad, tanto en lo que se refiere a su pasado histórico como en lo que concierne al territorio en el que se asienta, ha constituido siempre, dentro de 
la tradición occidental, una parte fundamental de la educación de los jóvenes. La Geografía y la Historia desempeñan una función vertebradora dentro del ámbito de las humanidades, al establecer las coordenadas de espacio y de tiempo en las que se inserta cualquier realidad o proceso social. (ESPAÑA, 2001a, p. 1817).

Com isso, seria mais apropriado que a área viesse a se chamar "Ciências Sociais: Geografia e História" ou simplesmente "Geografia e História". Em um informe da Fundação Ortega y Gasset, que precedeu a aprovação do decreto 3473/2000, chegou-se a propor para a área o título "Ciencias Sociales: Geografía e História" (LÓPEZ DOMECH, 2001, p. 663). Entretanto, não foi isso que ocorreu, no novo decreto de mínimos a área continuou sendo denominada "Ciencias Sociales, Geografía e História" (ESPAÑA, 2001a). Neste caso, há uma diferença fundamental na utilização de vírgula - inclusiva - ou dois pontos - restritivo. Para ser mais fiel à realidade, em vez de vírgula, deveriam ser usados dois pontos.

Como aponta Souto González (2004a), são antigas as dúvidas sobre a denominação utilizada pelos governos - segundo ele, vêm desde o debate que precede a promulgação da LOGSE - e conseqüentemente as ambigüidades decorrentes disto. Mas, como sabemos, há sempre um currículo oficial e um currículo real: por exemplo, no Instituto de Enseñanza Secundaria San Isidro ${ }^{111}$, de Madri, na lista de matérias oferecidas na ESO aparece: "Ciencias Sociales (Geografía e História)"112. Os parênteses, como os dois pontos, restringem.

Consolidando uma tendência que informalmente já vinha sendo praticada anteriormente $^{113}$, o primeiro ciclo da ESO assume um caráter mais geral, bidisciplinar, e o segundo ciclo um caráter mais específico, disciplinar. "En el primer ciclo, se ha optado por introducir en cada curso contenidos de ambas materias. [...]

111 O Instituto San Isidro está para a Espanha como o Colégio Pedro II está para o Brasil em termos de importância histórica e referência de ensino. Veja o que diz a introdução do breve histórico constante de sua página na Internet: "Situado en el corazón de la capital, cerca de su Plaza Mayor, el Instituto San Isidro tiene el privilegio de ser probablemente el centro educativo más antiguo de España, heredero de los Estudios de la Villa (1346), del Colegio Imperial (1603), y también de los Reales Estudios (1625), por nuestras aulas pasaron el Seminario de Nobles, la Academia de Matemáticas de Felipe II, la Facultad de Medicina, la Escuela de Arquitectura, la Facultad de Filosofía y Letras y la Facultad de Artes. Los mejores tratados de enseñanza de la España del pasado, fueron redactados por personas vinculadas a este centro." (Instituto de Enseñanza Secundaria San Isidro. La Historia del Instituto San Isidro. Disponível em: <www.educa.madrid.org/web/ies.sanisidro.madrid/historia.htm>. Acesso em: 21 ago. 2008).

112 Instituto de Enseñanza Secundaria San Isidro. Materias comunes del $1^{\circ}, 2^{\circ}, 3^{\circ}$ y $4^{\circ}$ curso de la ESO. Disponível em: <www.educa.madrid.org/web/ies.sanisidro.madrid/ESO.htm>. Acesso em: 21 ago. 2008.

113 Embora antes tivesse um caráter multidisciplinar, fazendo jus ao título "Ciências Sociais, Geografia e História" e não bidisciplinar como agora. 
En el segundo ciclo, que exige una mayor especialización, ha parecido conveniente separar los contenidos de ambas materias." (ESPAÑA, 2001a, p. 1817).

Não há nenhuma explicação convincente para essa opção, como aponta de forma incisiva Eugenio García Almiñana, catedrático de Instituto e coordenador do grupo Edetania de Valência:

Nos llama poderosamente la atención que cuando se afirma que en el primer ciclo se opta por combinar la Geografía con la Historia, no se ofrezca ninguna explicación razonada o científica al respecto, ni tampoco cuando se opta por lo contrario en el segundo ciclo. (GARCÍA ALMIÑANA, 2001, p. 635).

Fica claro que os redatores do decreto 3473 lançaram mão da passivização e da nominalização como estratégias de reificação ${ }^{114}$ do currículo, como forma de não assumir claramente uma posição, de obscurecer o sujeito da mudança curricular.

Além dessas mudanças, o novo decreto de enseñanzas mínimas prescinde da santísima trinidad, como diz López Domech (2001), ou seja, deixa de falar em conceitos, procedimentos e atitudes, listando apenas conteúdos.

No primeiro curso da ESO, coube à Geografia desenvolver os temas a seguir, enquanto que a História ficou responsável nos itens subseqüentes (itens de 5 a 9) pelos conteúdos de Prehistoria y Historia Antigua:

\section{Primer curso Contenidos}

LA TIERRA Y LOS MEDIOS NATURALES.

1. El planeta Tierra. La Tierra, planeta del sistema solar. Los movimientos de la Tierra y sus consecuencias. La representación de la Tierra. Mapas e imágenes.

2. Los elementos del "medio natural". La composición de la Tierra. Las placas terrestres y su distribución. Continentes y océanos. El relieve terrestre. Las grandes unidades del relieve de los continentes y su distribución. El relieve de los fondos oceánicos. La atmósfera y los fenómenos atmosféricos. Los climas y su reparto geográfico. Los seres vivos: la vegetación, el suelo y los animales. Las aguas continentales.

3. Los medios naturales y los recursos. Su distribución geográfica. Los medios naturales en relación con su manejo por los grupos humanos. Los medios húmedos, las regiones polares, las tundras, el bosque boreal, las montañas alpinas y los desiertos. Los bosques tropicales y las sabanas. Los medios templados, con especial referencia a los medios templados de Europa y de España. Conservación y gestión sostenible de medios y recursos.

\footnotetext{
114 Um dos modus operandi da ideologia, segundo Thompson (2000).
} 
4. Los riesgos naturales. Los riesgos climáticos: sequías, Iluvias torrenciales y ciclones tropicales. Los terremotos y las erupciones volcánicas. (ESPAÑA, 2001a, p. 1818).

No segundo curso, a Geografia ficou responsável pela seguinte lista de temas, enquanto que à História coube os conteúdos sobre Edad Media (itens de 5 a 9):

\section{Segundo curso Contenidos}

LAS SOCIEDADES HUMANAS.

1. La población mundial. La distribución geográfica de la población mundial. La dinámica de la población. Movimiento natural y movimientos migratorios. Las estructuras demográficas. El crecimiento de la población.

2. La actividad económica de las sociedades. El funcionamiento de la actividad económica. Producción, intercambio y consumo. Los agentes económicos. Los factores productivos. Recursos naturales, trabajo y capital. Características de la actividad económica. La economía europea y la economía española. Sociedad y economía de la información.

3. La organización de las sociedades. La estructura de la sociedad. Estratificación social. La división técnica y social del trabajo. La dinámica de la sociedad. Los procesos de cambio y conflicto social. Principales características de la sociedad europea y de la sociedad española. La diversidad cultural de los grupos humanos.

4. La organización política de las sociedades. El Estado como entidad política y geográfica. Organizaciones subestatales y supraestatales. Los regímenes políticos. Estados democráticos, dictaduras y otros Estados no democráticos. El mapa político de España. El mapa de la Unión Europea. El mapa político del mundo. La Organización de las Naciones Unidas. (ESPAÑA, 2001a, p. 1818).

No terceiro curso, ficaram exclusivamente temas de Geografia, como se observa pela lista a seguir:

\section{Tercer curso Contenidos}

LOS ESPACIOS GEOGRÁFICOS.

1. Las actuaciones de la sociedad sobre los medios naturales. Espacios geográficos y actividades económicas. Las relaciones entre naturaleza y sociedad. La formación de los espacios geográficos. Las actividades agrarias. Tipos principales. La actividad pesquera. Los paisajes agrarios y su reparto geográfico. Las fuentes de energía, las materias primas y la industria. Su distribución geográfica. Los espacios industriales. Los servicios. El comercio, los transportes y las comunicaciones. El turismo. Los espacios comerciales. Las redes de transporte y comunicaciones en el mundo. Los espacios de ocio. Los problemas derivados de la sobreexplotación del medio natural. Las consecuencias medioambientales de las actividades humanas. Las crisis medioambientales.

2. La ciudad como espacio geográfico. El poblamiento humano. Poblamiento rural y poblamiento urbano. La rururbanización. La ciudad. Las actividades urbanas. El 
espacio interior de las ciudades. La diversidad de las estructuras urbanas. El crecimiento espacial de las ciudades. Conurbaciones y megalópolis. La urbanización del territorio. Los problemas urbanos.

3. El espacio geográfico español. Las grandes unidades físicas. Las regiones naturales. Los problemas ambientales en España. La población española. Las actividades económicas. La modernización de las actividades agrarias y la reestructuración de la industria. El desarrollo de los servicios. Las ciudades españolas y el proceso de urbanización. La organización territorial del Estado en la Constitución de 1978. La organización autonómica del Estado. El papel de los recursos físicos y humanos, de la evolución histórica y del desarrollo económico contemporáneo en la articulación del territorio. La diversidad geográfica de España: estudio geográfico de las Comunidades Autónomas.

4. El espacio mundo y sus problemas. Un mundo progresivamente interrelacionado. Los efectos de la mundialización. La formación de un espacio geográfico mundial. Los problemas del mundo actual vistos desde una perspectiva geográfica. El crecimiento de la población y la evolución de los recursos. Las desigualdades socioeconómicas y ambientales. Las relaciones Norte-Sur. Los conflictos políticos en el mundo actual. La diversidad geográfica del mundo. Estudios de grandes conjuntos regionales y de algunos Estados, con especial atención a Europa e Iberoamérica. (ESPAÑA, 2001a, p. 1819).

A História ficou concentrada no quarto curso, desenvolvendo assuntos de "Idade Moderna", "Idade Contemporânea" e "Mundo atual". No quarto curso permaneceu ainda, como um resquício do decreto 1007/1991 e uma tentativa de justificar a manutenção da vírgula depois de Ciencias Sociales, o tema "A vida moral e a reflexão ética".

Além da distribuição por curso e do fim da "santíssima trindade", o que mais chama a atenção é o enorme aumento de conteúdos em comparação com o currículo anterior. Do temário da Geografia, são 26 subtítulos a serem desenvolvidos no primeiro curso, 32 no segundo, e no terceiro, no qual os temas são exclusivamente de Geografia, são 56 subtítulos! Esse excesso de conteúdos é um retrocesso em termos didático-pedagógicos. Como já apontou Guijarro Gutiérrez (1997, p. 36) "avanzar por el camino de la reducción temática" é um princípio pedagógico básico de todo ensino inovador. E, observe, ele já considerava muito extenso o programa de enseñanzas mínimas do decreto 1007/1991. Aliás, o termo enseñanzas mínimas revela-se cada vez mais se tratar apenas de um eufemismo.

López Domech (2001), então pertencente ao quadro do Instituto San Isidro, é um dos que denunciam o excesso de conteúdos do decreto 3473/2000 e, corroborando Guijarro Gutiérrez (1997), a impossibilidade de um ensino inovador 
frente ao decreto de mínimos. Para ele, frente a esse cenário a única coisa que se pode fazer é uma apresentação rápida e superficial de cada tema e recorrer ao exame clássico. Não há tempo sequer para um exercício de compreensão e o aluno que quiser ir além desse conteúdo ligeiro deve fazê-lo fora da sala de aula, ou seja, não o fará (LÓPEZ DOMECH, 2001). Na conclusão de seu artigo, o professor reforça a crítica ao Ministerio de Educación y Ciencia (MEC) e sua crença na importância da redução dos conteúdos:

Esta es la opción: saber menos cosas pero aprender a manejarse y comprender la Geografía, o saber más cosas y dejar esa formación para posteriores etapas. Creo que el MEC se equivoca al decantarse por la segunda de las opciones (¿le hemos preparado los docentes el camino para llegar a esta conclusión?) porque el cúmulo de conocimientos, sencillamente, crudamente, se olvida, mientras que el adiestramiento en la reflexión y conocimiento de la Geografía no se olvida. (LÓPEZ DOMECH, 2001, p. 668-669, grifo do autor).

Na mesma coletânea García Almiñana, do grupo Edetania, também critica o excesso de conteúdos da proposta governamental:

En las reuniones científicas que hemos tenido con grupos de trabajo geográficos de diversas autonomías siempre se señala lo mismo: bastantes contenidos son inadecuados, los materiales curriculares son muy extensos para las horas marcadas por las autoridades educativas para nuestra disciplina, integrada en las Ciencias Sociales, hecho que no nos parece demasiado oportuno. (GARCÍA ALMIÑANA, 2001, p. 632-633).

Souto González (2003, p. 288) vai além e afirma que o decreto 3473 significa uma volta "a la cultura enciclopédica del bachillerato franquista: los temarios recuerdan a los de 1957, los itinerarios al sistema dual y la gestión docente anula las escasas conquistas democráticas del control social a través del consejo escolar".

Muitos educadores são contrários à mescla de Geografia e História no primeiro ciclo da ESO e defendem que essas disciplinas sejam ensinadas separadamente.

García Almiñana (2001), como se depreende do trecho acima e de outras passagens de seu artigo, é um dos que defendem a separação da Geografia da área de Ciências Sociais e seu ensino autônomo ao longo de toda a educação secundária obrigatória. 
Souto González (1999), que é ligado ao grupo Gea-Clio, critica o fato de que em geral há um interesse exagerado por parte dos grupos de inovação pedagógica pela introdução de "novas áreas de conhecimento". Para ele, grupos como o Cronos, o IRES e o Insula Barataria defendem um enfoque interdisciplinar para as Ciências Sociais - é o caso também do grupo Asklepios - em detrimento das disciplinas isoladas. Em seguida, faz uma defesa da autonomia da Geografia: "Como hemos venido manteniendo a lo largo de estas páginas, creemos firmemente que la geografía puede aportar um conocimiento sólido para dilucidar problemas sociales en los centros educativos." (SOUTO GONZÁLEZ, 1999, p. 340). Acredita, posição com a qual concordo, que a Geografia tem sido responsável pela introdução de informações e conhecimentos procedentes de outros campos disciplinares. Os limites entre as ciências, especialmente as sociais, não são rígidos, na realidade o que as separam são fronteiras bastante dilatadas e permeáveis. Com isso a Geografia pode lançar mão de conceitos de outros campos disciplinares Economia, Sociologia, Filosófica, Política etc. - para enriquecer sua análise da realidade, sem perder sua identidade frente a eles, preservando sua especificidade analítica e sua tradição no sistema de ensino.

Ocorre que na prática as disciplinas são separadas, justapostas, já que assim foram interpretadas pelas editoras e pelos autores de livros-texto. $\mathrm{Na}$ Espanha, como no Brasil, há uma forte presença do livro didático na construção do currículo real. Ao analisar a realidade daquele país, Gimeno Sacristán (2000, p. 24) confirma essa avaliação: "Os currículos se baseiam em materiais didáticos diversos, entre nós quase que exclusivamente nos livros-texto, que são os verdadeiros agentes de elaboração e concretização do currículo.".

Souto González (1999, p. 46) também constata o peso do livro didático na prática escolar: "El profesorado, como consecuencia de su contexto profesional, suele trabajar en mayor medida con fuentes secundarias (los programas de los manuales) que con las primarias (los temarios y las intenciones legislativas).". E os manuais estão organizados de forma que haja uma justaposição de temas geográficos e históricos, não uma integração. Nos livros didáticos, em geral, há uma unidade com os temas de Geografia, seguida de outra com os de História ou vice- 
versa. E isso não é de agora, como já apontaram diversos autores (CAPEL; LUIS; URTEAGA, 1984; SOUTO GONZÁLEZ, 1999; GARCÍA ALMIÑANA, 2001). Isso talvez se explique pelo fato de que são diferentes os recortes da realidade feitos pelo campo disciplinar da Geografia e o da História. E a idéia simplista de que a Geografia cuida apenas da sincronia e a História da diacronia não resolve o problema. Ambas cuidam, ou deveriam, dos dois, entretanto, é fato que o olhar da Geografia sobre o tempo é diferente do da História, assim como também essa vê o espaço de forma diferente daquela.

Além do excesso de conteúdos e das justaposições, há diversas redundâncias, como é o caso de temas que são estudados na área de Ciencias de la Naturaleza e Biología y Geología (ver lista abaixo) e também na área de Ciencias Sociales, Geografía e Historia. Parte do temário listado abaixo, estudado em Ciências da Natureza ( $1^{\circ}$ curso da ESO) e em Biologia e Geologia ( $2^{\circ}$ curso) são também estudados em Geografia ( $1^{\circ}$ curso da ESO), como se pode verificar algumas páginas atrás.

\section{Ciencias de la Naturaleza \\ Primer curso \\ Contenidos \\ LA TIERRA EN EL UNIVERSO. \\ 1. El Universo, la Vía Láctea y el Sistema Solar. La observación del Universo: planetas, estrellas y galaxias. \\ Evolución histórica del conocimiento del Universo. La Vía Láctea y el Sistema Solar. Características físicas de la Tierra y de los otros componentes del Sistema Solar. \\ Los movimientos de la Tierra: las estaciones, el día y la noche, los eclipses y las fases de la Luna. Las capas de la Tierra: Núcleo, Manto, Corteza, Hidrosfera, Atmósfera y Biosfera. \\ $[\ldots]$}

\section{Biología y Geologia \\ Cuarto curso \\ Contenidos}

LA DINÁMICA DE LA TIERRA.

1. El modelado del relieve terrestre. Concepto de relieve. Agentes y procesos externos: meteorización, erosión, transporte y sedimentación. Factores externos del modelado del relieve: litológicos, estructurales, dinámicos, climáticos y antrópicos. El modelado litoral. El modelado kárstico. Los sistemas morfoclimáticos.

Clasificación. Los sistemas morfoclimáticos de zonas templadas y de zonas desérticas.

2. Tectónica de placas. Distribución geográfica de terremotos y volcanes. Wegener y la deriva continental. La expansión del fondo oceánico. Las placas litosféricas. Bordes de placa. Pruebas de la tectónica de placas. 
3. Fenómenos geológicos asociados al movimiento de las placas. Los terremotos. El plano de Bennioff. Vulcanismo terrestre. Las dorsales oceánicas. Las fosas submarinas. La subducción. La formación de cordilleras. Las estructuras tectónicas: pliegues, fallas y mantos de corrimiento.

4. La historia de la Tierra. Origen de la Tierra. El tiempo geológico. Historia geológica de la Tierra: las eras geológicas. Los fósiles como indicadores. (ESPAÑA, 2001a, p. 1813-1816).

Por isso Souto González (2003, p. 290), ao estudar os Decretos Reais do Ministerio de Educación y Ciencia, afirma comprovar que:

[...] la estructura de los temas de geografía en la ESO es obsoleto, pues se vuelve a incidir en una amalgama de contenidos propios de las Ciencias de la Tierra (geología, hidrología,...) desvirtuando el objeto de conocimiento de la geografía en la que el estudio del medio se hace desde la perspectiva de las actividades humanas. Aspectos esenciales como la interacción entre la sociedad y el medio desaparecen. Esto es algo fundamental por ejemplo para entender qué es un recurso. Asimismo, se habla de los riesgos naturales, pero nada se dice de las acciones humanas que conducen a agravarlos e incluso a provocarlos.

O fim dessas redundâncias por si só contribuiria para a redução do excesso de conteúdos e também abriria espaço no currículo para trabalhar temas que ajudassem a melhor compreender a relação sociedade-natureza. Como se percebe, falta integração com a área de Ciências da Natureza.

Finalmente, há mais uma contradição evidente na área de Ciencias Sociales, Geografía e Historia da ESO: os professores da área são licenciados em Geografia ou em História (há a possibilidade de uma terceira formação mais especializada ainda: em História da Arte). Ou seja, os estudantes são formados numa ou noutra disciplina, mas na hora em que vão à sala de aula, trabalhar como professores, têm de lecionar as duas (ou as três, considerando que parte dos conteúdos da área é de História da Arte). Como esclarece Valdeón Baruque (2004, p. 69):

Hasta hace unos años la licenciatura de Historia incluía también estudios propios de geografía, así como de historia del arte, lo que en buena medida obedecia a que la principal salida de los licenciados en dicha materia era la enseñanza secundaria, en donde la geografía y la historia, incluyendo ésta la parte del desarrollo artístico a lo largo del tiempo, constituían, y siguen constituyendo en el presente, una asignatura conjunta. Pero últimamente el panorama referente a esos estudios ha experimentado um giro espetacular. Hoy en día existen en las universidades españolas tres licenciaturas independientes, la de historia, la de geografía y la de historia del arte. 
Pero lo más grave del caso es que los estudiantes de esas licenciaturas, salvo que a la hora de elegir asignaturas optativas muestren interés por las disciplinas tradicionalmente próximas a la que están cursando, desconocen por completo esos otros campos.

Isso é a evidência mais acabada do quão enganosas são algumas interpretações sobre a interdisciplinaridade. A análise interdisciplinar não pode prescindir das disciplinas, não as enfraquece (ou não deveria enfraquecê-las), ao contrário. Diante do enorme avanço do conhecimento na chamada era informacional, de que fala Castells (2000), não é possível a interdisciplinaridade se concretizar num indivíduo, num professor isolado. Trata-se, isto sim, de um processo de apreensão da realidade necessariamente coletivo, no qual cada uma das disciplinas (e seu professor responsável) dá sua contribuição para a compreensão do mundo de acordo com o olhar particular do respectivo campo disciplinar, conforme sua fundamentação teórico-metodológica. Como vimos, um exemplo interessante de interdisciplinaridade foi dado pelos frankfurtianos com 0 "materialismo interdisciplinar" (NOBRE, 2004).

Com essa visão distorcida sobre a interdisciplinaridade nas Ciências Sociais, a Geografia acaba perdendo espaço, devido a menor quantidade de formados e ao desconhecimento de seu arcabouço teórico-metodológico por parte dos professores formados em História ou História da Arte. Entre outros, García Almiñana (2001, p. 633) aponta isso:

En los actuales Institutos de Secundaria y Bachillerato hay poços licenciados en Geografía. Ello significa que nuestra disciplina la imparten, a veces, personas con buena voluntad pero que no conocen suficientemente las nuevas metodologías de la ciencia geográfica, ni las últimas tendencias. Ello se refleja en las aulas y en la transmisión de unos conocimientos muchas veces tradicionales y bastante alejados de los parámetros actuales de nuestra ciencia.

Souto González (2004a) para evidenciar a posição subalterna da Geografía frente à História, usa como exemplo o número de publicações em revistas de didática de Geografia e História, como a Iber e a Aula de Innovación Educativa. Como mostra a tabela 13, a proporção de artigos de Geografia no conjunto da didática das Ciências Sociais é relativamente baixa, bem inferior aos de História: 
Tabela 13. Monográficos da Revista Iber dedicados à Geografia e a outros temas da didática das Ciências Sociais*

\begin{tabular}{|c|c|c|c|c|c|c|}
\hline \hline $\begin{array}{c}\text { Temas } \\
\text { gerais }\end{array}$ & História & Geografia & Arte & $\begin{array}{c}\text { Ciências } \\
\text { Sociais }\end{array}$ & Filosofia & Economia \\
\hline \hline 7 & 14 & 5 & 5 & 5 & 1 & 1 \\
\hline
\end{tabular}

*Organizado pelo autor sobre 38 números editados.

Fonte: Souto González (2004a, p. 74).

Para Souto González (2004a, p. 74), este quadro "evidencia la posición secundaria de esta disciplina respecto a la historia en la configuración del área, en la formación del profesorado y en las tradiciones curriculares de España".

É certo que o escopo dos dados é reduzido, mas ao se somar a outras evidências permite concluir que a Geografia tem uma posição subalterna dentro da área de Ciências Sociais, Geografia e História na ESO. Com isso, para ser fiel à realidade a área deveria se chamar "Ciencias Sociales: Historia e Geografía". Porém, como pensam os autores mencionados acima, melhor seria "cambiar la realidad", garantindo à Geografia o mesmo protagonismo que tem a História. Para que isso ocorra, evidentemente, é fundamental o fortalecimento teóricometodológico do campo disciplinar. Como se pode deduzir da leitura do trecho a seguir, isso já vem acontecendo no nível universitário, onde se concentra majoritariamente a produção do conhecimento geográfico:

Los nuevos estudios de geografía, vigentes en la actualidad, supusieron romper con una concepción de la geografía como ciencia auxiliar o complementaria de la historia, concepción de clara influencia francesa, para, más en sintonia con la orientación anglosajona, afirmar la independencia intelectual y metodológica de nuestra ciencia como forma de conocimiento autónoma. (ARROYO LLERA, 2004, p. 78).

Agora falta esse fortalecimento acontecer também no nível secundário, onde ocorre a reprodução ${ }^{115}$ do conhecimento geográfico. E isso deve passar pelo ensino de Geografia de forma autônoma na ESO, como defendem autores como García Almiñana (2001) e Souto González (1999), fortalecendo sua especificidade analítica e, ao mesmo, sua contribuição para a apreensão interdisciplinar da realidade.

115 Embora a referência para a produção dos conteúdos desenvolvidos na educação secundária seja a produção universitária, não se pode desprezar o fato de que o professor secundário além de reprodutor, também produz conhecimento. E mesmo a reprodução não é ipsis litteris, implica sempre um trabalho de recriação. 


\section{BACHILLERATO}

Sob o governo do Partido Popular também ocorreram modificações no currículo do bachillerato e, como já ocorrera com a ESO, tais mudanças foram feitas com base no artigo 4.2 da LOGSE. Assim, o Decreto Real 3474 de 29 de dezembro de 2000 modificou o Decreto 1178/1992 e estabeleceu novas enseñanzas mínimas para o bachillerato espanhol.

Nesse decreto, a Geografia continua sendo ministrada no $2^{\circ}$ curso de bachillerato da modalidade Humanidades y Ciencias Sociales. Os objetivos da disciplina permanecem basicamente os mesmos da lei anterior, como se pode inferir do primeiro parágrafo da introdução (a seguir). O espaço geográfico permanece como objeto principal de estudo, especialmente o espaço espanhol e sua inserção na União Européia e no sistema mundial, assim como a interação sociedadeterritório.

Uma novidade: na introdução da Geografia, o decreto afirma que a disciplina desenvolve certas habilidades e destrezas, como a capacidade de atuar no espaço - sem definir de que espaço se trata - e a competência ou consciência espacial. Continua não havendo a preocupação de se definir os conceitos utilizados, como espaço, território e sociedade. Mas pelo trecho a seguir fica evidente que o espaço é uma construção social e inclusive pode condicionar as relações existentes na sociedade:

La Geografía estudia la organización del espacio terrestre, entendido éste como el conjunto dinámico de relaciones entre el territorio y la sociedad que actúa en él. Por tanto, el espacio es para la Geografía actual una realidad relativa, dinámica y heterogénea que resulta de los procesos protagonizados por la estructura social, sin olvidar que esos procesos pueden estar condicionados, a su vez, por el propio espacio preexistente. (ESPAÑA, 2001b, p. 1900).

Entretanto, as mudanças mais significativas podem ser detectadas nos conteúdos a serem ensinados, como se pode observar na lista a seguir. 


\section{CONTENIDOS}

\section{España en el sistema mundo:}

- El espacio geográfico: noción y características del espacio geográfico; elementos e instrumentos de información y representación geográfica; nociones de análisis de localizaciones y distribuciones espaciales.

- Globalización y diversidad en el mundo actual: procesos de mundialización y desigualdades territoriales; clasificaciones de las áreas geoeconómicas.

- Rasgos geográficos esenciales de España: situación geográfica; contrastes y diversidad internos; posición relativa en el mundo y en las áreas socioeconómicas y geopolíticas.

\section{España en Europa:}

- El camino hacia la integración europea: de las Comunidades Europeas a la Unión Europea; estructura territorial e institucional de la Unión Europea; perspectivas y retos de futuro.

- Naturaleza y medio ambiente en la Unión Europea: Ios contrastes físicos: relieve, clima e hidrografía; situación del medio ambiente y políticas comunitarias con incidencia ambiental.

- Territorio y sociedad de la Unión Europea: rasgos socioeconómicos generales de la Unión Europea y de los Estados miembros; disparidades regionales; políticas regionales y cohesión territorial.

- La posición de España en la Unión Europea: factores explicativos de la integración de España; consecuencias iniciales tras la integración; situación actual y perspectivas.

\section{Naturaleza y medio ambiente en España:}

Características generales del medio natural: diversidad geológica, morfológica, climática e hídrica.

- La variedad de los grandes conjuntos naturales españoles: identificación de sus elementos geomorfológicos, estructurales, climáticos y biogeográficos.

- Naturaleza y recursos en España: materias primas, fuentes y recursos energéticos.

- Naturaleza y medio ambiente español: situación, condicionantes y problemas; la protección de los espacios naturales.

- El agua: cuencas y vertientes hidrográficas; regímenes fluviales; regulación y distribución de los recursos hidráulicos.

\section{El espacio geográfico en las actividades económicas:}

- Acción de los factores socioeconómicos en el territorio español: evolución histórica, panorama actual y perspectivas.

- La pluralidad de los espacios rurales: transformación y diversificación de las actividades rurales y su plasmación en tipologías espaciales diversas; las dinámicas recientes del mundo rural.

- La reconversión de la actividad pesquera.

- Los espacios industriales: evolución histórica y características hasta la industrialización de la segunda mitad del siglo XX; crisis del modelo de desarrollo concentrado y reestructuración industrial; tendencias territoriales actuales de la industria española.

- Los espacios de servicios: proceso de terciarización de la economía española; la heterogeneidad de los servicios y su desigual impacto territorial; los transportes y las comunicaciones. Los espacios turísticos: factores explicativos del desarrollo turístico español; tipología de regiones turísticas; impacto espacial del turismo.

\section{Recursos humanos y organización espacial en España:}


- La población española: evolución de la población y de su distribución espacial; dinámica demográfica natural; movimientos migratorios exteriores, interiores y el fenómeno de la inmigración actual; estructura demográfica actual.

- El proceso de urbanización en España: complejidad del fenómeno urbano; evolución histórica de la urbanización; características del sistema urbano español; el declive del mundo rural.

- Morfología y estructura de las ciudades españolas: la huella de la historia de la ciudad preindustrial; la ciudad industrial; la ciudad de las recientes transformaciones sociales y económicas.

- La organización territorial de España en la Constitución de 1978. El Estado de las autonomías: origen, proceso y mapa autonómico. Caracteres geográficos básicos de cada una de las Comunidades Autónomas.

- Los desequilibrios territoriales: contrastes espaciales entre las Comunidades Autónomas; disparidades demográficas; desigualdades socioeconómicas; los desequilibrios regionales en España y las políticas regionales de la Unión Europea. (ESPAÑA, 2001b, p. 1901).

Como se observou na longa lista, trata-se de um conteúdo muito extenso para ser desenvolvido em apenas 4 horas semanais durante um ano letivo. Diversos autores criticam o caráter enciclopédico e o excesso de conteúdos desse novo programa de Geografia do bachillerato (LÁZARO Y TORRES, 2001; SOUTO GONZÁLEZ, 2003).

Para a catedrática de Instituto María Luisa de Lázaro y Torres: "Las dificultades que actualmente encuentran los alumnos que cursan la asignatura de Geografía de $2^{\circ}$ de bachillerato es la gran profundidad y amplitud de los contenidos que en ella se imparten [...]" (2001, p. 593). O que já era excessivo no decreto 1178/1992 ficou ainda mais extenso no 3474/2000. Aqui, enseñanzas mínimas, como na ESO, é puro eufemismo. Entretanto, essa avaliação não é consensual. García Almiñana (2001, p. 637) pensa que o novo currículo de Geografia do bachillerato é adequado, melhor que o anterior: "Nuestra opinión es que el actual curriculum equilibra, mejor que el anterior, los contenidos y hace mejor hincapié en los caracteres geográficos de unidad y diversidad del territorio español.".

Apesar do poder conformador oficial do decreto das enseñanzas mínimas, desde a LOGSE o agente de maior peso na construção do currículo real do bachillerato são as "Pruebas de Acceso a la Universidad", mais conhecidas pela sigla PAU. Tais provas desempenham papel correlato aos exames vestibulares no Brasil, entretanto, há diferenças, por exemplo, em seu formato. As PAU são 
organizadas por uma comissão formada por professores da universidade interessada em selecionar os alunos e por professores de bachillerato dos Institutos da região onde ela se encontra. Apesar de, formalmente, terem um sentido orientador, na prática, têm um caráter normativo porque condicionam o que deve ser ensinado e aprendido. Conforme opinião de diversos autores, tais como Climent López (2001), Escudero (1997), García Almiñana (2003) e Souto González (2003, 2004a), são as PAU que têm a maior influência na conformação do currículo do bachillerato espanhol.

O peso dessas provas fica patente, por exemplo, nas palavras de Climent López (2001, p. 617): “Las PAU condicionan la enseñanza del bachillerato, pues los estudiantes tienen entre sus metas la de superar dichas pruebas y el trabajo de sus profesores lógicamente se orienta en esa dirección". Souto González (2003, p. 291), analisando especificamente a Geografia, também deixa isso evidente:

\begin{abstract}
Además hemos de considerar que esta materia, por formar parte de la organización de segundo curso, es objeto de una prueba de evaluación externa: la Prueba de Acceso a la Universidad (PAU); este hecho condiciona la enseñanza y el aprendizaje de la misma, tanto en la selección de los contenidos como en la programación de las actividades.
\end{abstract}

Com isso a Geografia do bachillerato acaba sendo em grande medida um arremedo da Geografia universitária, portanto, inadequada para a compreensão do mundo por estudantes de secundária, mesmo que da etapa pós-obrigatória (17-18 anos). Para Souto González (2004a, p. 71) "la redacción de dichas pruebas muestra con rotundidad un predominio de una concepción de la geografía escolar anclada en las rutinas enciclopédicas y en una cultura obsoleta, que poco aporta a la comprensión de los grandes problemas mundiales". Em texto anterior, Souto González (2003) já afirmara que alguns estudos apresentados nos Colóquios de Didática da Geografia da AGE mostravam a inadequação das PAU.

Climent López (2001, p. 616), após reclamar que as PAU não contribuem para a aprendizagem significativa, apesar de este objetivo constar da legislação e ser defendido pelo pensamento didático dominante, constata: "Por ello podría afirmarse que las PAU no están contribuyendo de forma positiva a que los alumnos de bachillerato aprendam geografía.". 
Na prática a Geografia do bachillerato tem apenas caráter propedêutico e não formativo: a maioria da população não chega a esse nível de ensino e mesmo para aqueles que chegam, poucos a estudam, já que é ministrada apenas no $2^{\circ}$ curso da modalidade Humanidades e Ciências Sociais.

Com a aprovação da $L O C E$, o governo do Partido Popular planejava implantar uma prova geral na conclusão do bachillerato, como havia na época de Franco, a conhecida reválida. Entretanto, com a vitória dos socialistas, com a aprovação da Ley Orgânica de Educación ( $L O E$ ) e a conseqüente suspensão da lei dos populares, isso não chegou a se concretizar. Assim, as PAU permanecem como único exame de acesso à universidade e continuam determinando na prática o currículo da Geografia do bachillerato. 


\title{
A LOE e as enseñanzas mínimas
}

\author{
Educación Secundaria Obligatoria
}

Com a volta do Partido Socialista Obrero Español (PSOE) ao poder em 2004, como já vimos, a implantação da LOCE foi suspensa e no final de 2005 o governo socialista aprovou uma nova reforma educativa, a Ley Orgânica de Educación ( $L O E)$. Em conseqüência disto, é o artigo 6.1 desta nova lei que passa a regular as questões relativas ao currículo, a começar por sua conceituação. Quando se compara com a definição do artigo 4.1 da LOGSE, a única diferença que se nota é a introdução das competências básicas, ou seja, continua técnica, asséptica:

Artículo 6.

1. A los efectos de lo dispuesto en esta Ley, se entiende por currículo el conjunto de objetivos, competencias básicas, contenidos, métodos pedagógicos y criterios de evaluación de cada una de las enseñanzas reguladas en la presente Ley. (ESPAÑA, 2006a , p. 17166).

Para o objetivo desta pesquisa nos interessa discutir apenas os conteúdos e as competências, o que nos remete à análise das enseñanzas mínimas, definidas para todos os níveis do sistema educativo com base no artigo 6.2 da LOE (ver abaixo). As justificativas para sua definição são as mesmas que constavam do artigo 4.2 da LOGSE: garantir uma formação comum e a validade dos títulos correspondentes.

Artículo 6.

2. Con el fin de asegurar una formación común y garantizar la validez de los títulos correspondientes, el Gobierno fijará, en relación con los objetivos, competencias básicas, contenidos y criterios de evaluación, los aspectos básicos del currículo que constituyen las enseñanzas mínimas [...] (ESPAÑA, 2006a, p. 17166).

Com base nesse artigo da $L O E$, o Decreto Real 1631 de 29 de dezembro de 2006 definiu as novas ensenãnzas mínimas para a ESO, como veremos a seguir. Quanto à distribuição dos conteúdos mínimos entre as Comunidades Autônomas não houve nenhuma mudança em relação à lei anterior. Segundo o artigo 6.3: "Los 
contenidos básicos de las enseñanzas mínimas requerirán el 55 por ciento de los horarios escolares para las Comunidades Autónomas que tengan lengua cooficial y el 65 por ciento para aquéllas que no la tengan." (ESPAÑA, 2006a, p. 17166).

Antes de analisarmos os novos conteúdos das enseñanzas mínimas é imprescindível uma breve discussão sobre as "competências básicas". Elas são a principal novidade do novo decreto de mínimos, além disso, condicionam os objetivos de aprendizagem, a seleção de conteúdos, a avaliação e, como vimos no capítulo 3 da parte I, extrapolam em muito o sistema escolar, já que não são originárias do sistema produtivo.

Em março de 2000 aconteceu o Conselho Europeu Extraordinário de Lisboa. Nesse encontro de Chefes de Estado e de Governo da União Européia, então sob a presidência portuguesa, foi lançada a Estratégia de Lisboa. Depois de constatar que a União Européia se defronta com uma mudança significativa resultante de globalização e dos desafios da sociedade do conhecimento, foi estabelecido para 2010 um ambicioso objetivo estratégico: "tornar-se na [sic] economia baseada no conhecimento mais dinâmica e competitiva do mundo, capaz de garantir um crescimento econômico sustentável, com mais e melhores empregos, e com maior coesão social". (CONSELHO DA UNIÃO EUROPÉIA, 2001, p. 4). Para atingir tal objetivo a Educação foi considerada um "domínio-chave prioritário". O Conselho Europeu estabeleceu um Conselho de Educação que, por sua vez, definiu três objetivos concretos a serem atingidos até 2010:

1. Aumentar a qualidade e a eficácia dos sistemas de educação e formação na União Européia;

2. Facilitar o acesso de todos aos sistemas de educação e formação;

3. Abrir os sistemas de educação e formação ao resto do mundo. (CONSELHO DA UNIÃO EUROPÉIA, 2001, p. 7).

Esses três objetivos estratégicos se subdividem em treze objetivos conexos. Para o interesse deste trabalho, veremos apenas os cinco objetivos derivados do primeiro objetivo estratégico, especialmente 0 1.2, que trata das competências:

1.1. Melhorar a educação e formação dos professores e formadores;

1.2. Desenvolver as competências para a sociedade do conhecimento; 
1.3. Garantir a todos o acesso às tecnologias da informação e comunicação (TIC);

1.4. Aumentar o recrutamento nos estudos científicos e técnicos;

1.5. Utilizar da melhor forma os recursos.

(CONSELHO DA UNIÃO EUROPÉIA, 2001, p. 8-10).

Ainda em 2001, o Conselho de Educação criou um grupo de trabalho encarregado de definir as competências no contexto do programa Educação e Formação 2010. Esse grupo elaborou um quadro de referência (ver quadro 14) com as competências-chave necessárias na sociedade do conhecimento:

\section{Quadro 14. Competências-chave para a aprendizagem ao longo da vida (quadro de referência europeu)}

1. Comunicação na língua materna;

2. Comunicação em línguas estrangeiras;

3. Competência matemática e competências básicas em ciências e tecnologia;

4. Competência digital;

5. Aprender a aprender;

6. Competências interpessoais, interculturais e sociais e competência cívica;

7. Espírito empresarial;

8. Expressão cultural.

Fonte: Comissão das Comunidades Européias (2005, p. 15).

Com base na proposta acima, o Decreto Real 1631/2006 definiu as competências básicas para a ESO, como explicita o trecho a seguir:

En el marco de la propuesta realizada por la Unión Europea, y de acordo com las consideraciones que acaban de exponer, se han identificado ocho competencias básicas:

1. Competencia en comunicación lingüística.

2. Competencia matemática.

3. Competencia en el conocimiento y la interacción con el mundo físico.

4. Tratamiento de la información y competencia digital.

5. Competencia social y ciudadana.

6. Competencia cultural y artística.

7. Competencia para aprender a aprender

8. Autonomia e iniciativa personal.

(ESPAÑA, 2007a, p. 686).

Como se pode observar, a lista das oito competências da ESO segue a proposta da União Européia com poucas mudanças. O decreto de mínimos fala de 
competência em comunicação lingüística, englobando as competências 1 e 2 do quadro de referência europeu, e introduz uma novidade que não constava daquela lista: "a competência sobre o conhecimento e a interação com o mundo físico". O restante da lista, embora não na mesma ordem, segue a proposta do Conselho Europeu.

Como se observa, a introdução das competências no currículo da ESO não é uma iniciativa isolada da Espanha. Isso é fruto de uma proposta da União Européia, no âmbito da Estratégia de Lisboa e do projeto Educação e Formação 2010, para fazer frente aos desafios da globalização e da sociedade do conhecimento, como é reiterado em diversas passagens do documento da Comissão das Comunidades Européias (2005).

Em consonância com a introdução das competências básicas no currículo da ESO, no decreto de mínimos consta um novo subtítulo - Contribución de la matéria a la adquisición de las competencias básicas - que em seu primeiro parágrafo destaca: "El carácter integrador de la materia de Ciencias sociales, geografía e historia hace que su aprendizaje contribuya a la adquisición de varias competencias básicas." (ESPAÑA, 2007a, p. 703). Na realidade as Ciências Sociais, Geografia e História contribuem, em maior ou menor grau, para o desenvolvimento de todas as oito competências.

Ao se discutir como a área pode contribuir para a aquisição das competências básicas, num dado momento, quando se analisava a contribuição para o desenvolvimento das competências sobre o conhecimento e a interação com o mundo físico, o documento afirma:

Dicha competencia incluye, entre otros aspectos, la percepción y conocimiento del espacio físico en que se desarrolla la actividad humana, tanto en grandes ámbitos como en el entorno inmediato, así como la interacción que se produce entre ambos. La percepción directa o indirecta del espacio en que se desenvuelve la actividad humana constituye uno de los principales ejes de trabajo de la geografía: la comprensión del espacio en que tienen lugar los hechos sociales y la propia vida del alumno, es decir, la dimensión espacial. (ESPAÑA, 2007a, p. 703).

Observe que se fala em "espaço físico em que se desenvolve a atividade humana". Entretanto, espaço em que se desenvolve a atividade humana é espaço social, não físico. Em seguida afirma-se que um dos principais eixos de trabalho da 
Geografia é "a compreensão do espaço em que têm lugar os fatos sociais e a própria vida do aluno". Esses trechos evidenciam que no novo currículo da ESO o espaço é concebido como palco ou receptáculo, portanto, separado da sociedade.

Vejamos então os conteúdos da área em cada um dos quatro cursos da ESO, com destaque para os de Geografia, e as competências para as quais contribuem:

\section{Primer curso \\ Contenidos}

\section{Bloque 1. Contenidos comunes.}

- Lectura e interpretación de imágenes y mapas de diferentes escalas y características. Percepción de la realidad geográfica mediante la observación directa o indirecta. Interpretación de gráficos y elaboración de estos a partir de datos.

- Obtención de información de fuentes diversas (iconográficas, arqueológicas, escritas, proporcionadas por las tecnologías de la información, etc.) y elaboración escrita de la información obtenida.

- Localización en el tiempo y en el espacio de los periodos, culturas y civilizaciones y acontecimientos históricos. Representación gráfica de secuencias temporales.

- Identificación de causas y consecuencias de los hechos históricos y de los procesos de evolución y cambio relacionándolos con los factores que los originaron.

- Conocimiento de los elementos básicos que caracterizan las manifestaciones artísticas más relevantes, contextualizándolas en su época. Valoración de la herencia cultural y del patrimonio artístico como riqueza que hay que preservar y colaborar en su conservación.

\section{Bloque 2. La Tierra y los medios naturales.}

- La representación de la tierra. Aplicación de técnicas de orientación y localización geográfica.

- Caracterización de los principales medios naturales, identificando los componentes básicos del relieve, los climas, las aguas y la vegetación; comprensión de las interacciones que mantienen. Observación e interpretación de imágenes representativas de los mismos. Valoración de la diversidad como riqueza que hay que conservar.

- Localización en el mapa y caracterización de continentes, océanos, mares, unidades del relieve y ríos en el mundo, en Europa y en España. Localización y caracterización de los principales medios naturales, con especial atención al territorio español y europeo.

- Los grupos humanos y la utilización del medio: análisis de sus interacciones. Riesgos naturales. Estudio de algún problema medioambiental como, por ejemplo, la acción humana sobre la vegetación, el problema del agua o el cambio climático. Toma de conciencia de las posibilidades que el medio ofrece y disposición favorable para contribuir al mantenimiento de la biodiversidad y a un desarrollo sostenible.

(ESPAÑA, 2007a, p. 704-705).

A falta de confiança nos professores para organizar suas aulas, como já denunciou Souto González (2003), permanece. Os conteúdos, como no decreto 
anterior dos populares, continuam divididos em cursos. Entretanto, ocorreram diversas mudanças. O primeiro curso da ESO é aberto por um bloco de conteúdos de Geografia, História e História da Arte, que possibilitam o desenvolvimento de praticamente todas as competências básicas, mas por seu caráter procedimental, especialmente a de aprender a aprender.

Como já ocorrera com o decreto de mínimos 3473/2000, não se fala em conteúdos procedimentais, conceituais e atitudinais. Entretanto, o bloco 1 tem um caráter eminentemente procedimental e mesmo atitudinal quando propõe a "Valoración de la herencia cultural y del patrimonio artístico como riqueza que hay que preservar y colaborar en su conservación." (ESPAÑA, 2007a, p. 705). É de se supor que esses conteúdos serão desenvolvidos à medida que os dos outros dois blocos forem trabalhados.

O segundo bloco "La Tierra y los medios naturales", ficou reservado ao temário geográfico e permite o desenvolvimento das competências social e cidadã, de conhecimento e interação com o mundo físico, tratamento da informação e competência digital. Mantém o mesmo nome do bloco de Geografia que abria o primeiro curso da ESO no decreto 3473/2000. Entretanto, houve mudanças importantes, algumas das quais respondendo às críticas recebidas na ocasião. Por exemplo, resolve-se parte da redundância com as Ciências da Natureza ao suprimir os subtítulos que tratavam do planeta Terra no sistema solar e sua estrutura geológica - "1. El planeta Tierra. La Tierra, planeta del sistema solar. Los movimientos de la Tierra y sus consecuencias. [...] 2. Los elementos del 'medio natural'. La composición de la Tierra. Las placas terrestres y su distribución". (ESPAÑA, 2001a, p. 1818). Também no Decreto Real 1631/2006 esses temas são contemplados na área de "Ciencias de la naturaleza". Ainda se observam redundâncias entre alguns temas dessa área, mas foram reduzidos os conteúdos próprios das Ciências da Terra. Como foi apontado por Souto González ${ }^{116}$ (2003), no decreto anterior esses conteúdos desvirtuavam o objeto de conhecimento da Geografia, no qual o estudo do meio deve-se fazer desde a perspectiva das atividades humanas. No decreto do Partido Popular, ainda segundo o geógrafo de

\footnotetext{
116 Rever a citação na página 253.
} 
Valência, aspectos essenciais da disciplina, como a interação homem-meio, desapareciam. Enfim, com essas mudanças, a Geografia vê fortalecido seu papel de ciência humana e pode contribuir mais para o desenvolvimento da competência social e cidadã. Especialmente porque, como se pode ver no bloco 2 do $1^{\circ}$ curso (página anterior), fala-se em "riscos naturais", mas para compreendê-los estuda-se "os grupos humanos e a utilização do meio", fazendo uma "análise de suas interações”. Lembremos que no decreto anterior se estudava os riesgos naturales, porém, como apontou Souto González (2003), nada se falava das ações humanas que levam a agravá-los e inclusive a provocá-los. O novo decreto de mínimos propõe inclusive o estudo de algum problema ambiental para que os alunos percebam a ação humana sobre o meio ambiente e "tomem consciência das possibilidades que o meio oferece e contribuam para a manutenção da biodiversidade e o desenvolvimento sustentável". Embora sem retomar formalmente a santísima trinidad, trata-se de um conteúdo de caráter atitudinal.

O terceiro e último bloco do primeiro curso da ESO continua reservado à História - Sociedades prehistóricas, primeras civilizaciones y edad antigua -, portanto, não houve mudança em relação ao decreto anterior, no qual o segundo e último bloco (lá só havia dois) era dedicado à pré-História e História antiga. Como se percebe, a justaposição entre a Geografia e a História permanece.

Vejamos agora os conteúdos do segundo curso da ESO, com destaque para a Geografia:

\section{Segundo curso \\ Contenidos}

Bloque 1. Contenidos comunes.

- Localización en el tiempo y en el espacio de periodos y acontecimientos históricos. Nociones de simultaneidad y evolución. Representación gráfica de secuencias temporales.

- Reconocimiento de causas y consecuencias en los hechos y procesos históricos distinguiendo su naturaleza.

- Identificación de la multiplicidad causal en los hechos sociales. Valoración del papel de los hombres y las mujeres como sujetos de la historia.

- Búsqueda, obtención y selección de información del entorno, de fuentes escritas, iconográficas, gráficas, audiovisuales y proporcionadas por las tecnologías de la información. Elaboración escrita de la información obtenida. Transformación de información estadística en gráficos.

- Reconocimiento de elementos básicos que caracterizan los estilos artísticos e interpretación de obras significativas considerando su contexto. 
Valoración de la herencia cultural y del patrimonio artístico como riqueza que hay que preservar y colaborar en su conservación. Análisis de algún aspecto de la época medieval o moderna relacionado con un hecho o situación relevante de la actualidad.

\section{Bloque 2. Población y sociedad.}

- La población. Distribución. Aplicación de los conceptos básicos de demografía a la comprensión de los comportamientos demográficos actuales, análisis y valoración de sus consecuencias en el mundo y en España. Lectura e interpretación de datos y gráficos demográficos.

- Las sociedades actuales. Estructura y diversidad. Desigualdades y conflictos. Caracterización de la sociedad europea y española. Inmigración e integración. Análisis y valoración relativa de las diferencias culturales.

- La vida en el espacio urbano. Urbanización del territorio en el mundo actual y jerarquía urbana. Funciones e identificación espacial de la estructura urbana. Problemas urbanos. Las ciudades españolas. (ESPAÑA, 2007a, p. 706).

No segundo curso da ESO, o bloco 1 também apresenta um caráter interdisciplinar, dedicando-se a conteúdos de Geografia, História e História da Arte. Este bloco permite o desenvolvimento de quase todas as oito competências básicas, com destaque para a cultural e artística, a social e cidadã, a digital e tratamento da informação. Entretanto, como ocorrera no primeiro curso, por seu caráter procedimental, desenvolve especialmente a competência de aprender a aprender. Há também conteúdos atitudinais e a frase que indica isso é exatamente a mesma que aparecera no primeiro curso: "Valoración de la herencia cultural y del patrimonio artístico como riqueza que hay que preservar y colaborar en su conservación." (ESPAÑA, 2007a, p. 706).

Os dois primerios itens do bloco 2 repetem os temas de população e sociedade que eram tratados nos decreto anterior - 3473/2000 - e tinha o título de "Las sociedades humanas". Entretanto, há uma mudança importante: o último item do bloco 2, dedicado ao estudo da Geografia Urbana, entra no lugar do item do decreto anterior que era dedicado à Ciência Política e à Geografia Política. Os conteúdos do bloco 2 pretendem desenvolver as competências social e cidadã, cultural e artística, o conhecimento e a interação com o mundo físico e a Matemática.

O bloco 3 do segundo curso da ESO - "Las sociedades preindustriales" é dedicado integralmente ao temário histórico. Trata de conteúdos desde a Idade 
Média até o início da Era Moderna. Repete alguns dos temas que constavam do decreto anterior, sob o título "Edad Media".

O terceiro curso da ESO, seguindo uma estrutura que formalmente vem desde o Decreto Real 3474/2000, é voltado apenas ao temário geográfico, como se pode constatar pela lista abaixo:

\section{TERCER CURSO \\ Contenidos}

Bloque 1. Contenidos comunes.

- Obtención y procesamiento de información, explicita e implícita, a partir de la percepción de los paisajes geográficos del entorno o de imágenes, de fuentes orales y de documentos visuales, cartográficos y estadísticos, incluidos los proporcionados por las tecnologías de la información y la comunicación. Comunicación oral o escrita de la información obtenida.

- Realización de debates, análisis de casos o resolución de problemas sobre alguna cuestión de actualidad sirviéndose, entre otras, de las fuentes de información que proporcionan los medios de comunicación, valorando críticamente informaciones distintas sobre un mismo hecho, fundamentando las opiniones, argumentando las propuestas, respetando las de los demás y utilizando el vocabulario geográfico adecuado.

- Realización de trabajos de síntesis o de indagación, utilizando información de fuentes variadas y presentación correcta de los mismos, combinando diferentes formas de expresión, incluidas las posibilidades que proporcionan las tecnologías de la información y la comunicación.

Bloque 2. Actividad económica y espacio geográfico.

- La actividad económica. Necesidades humanas y recursos económicos. Conceptos, agentes e instituciones básicas que intervienen en la economía de mercado y su relación con las unidades familiares. Cambios en el mundo del trabajo.

- Las actividades agrarias y las transformaciones en el mundo rural. La actividad pesquera y la utilización del mar. La actividad y los espacios industriales. Diversidad e importancia de los servicios en la economía actual. Toma de conciencia del carácter agotable de los recursos, de la necesidad de racionalizar su consumo y del impacto de la actividad económica en el espacio.

- Localización y caracterización de las principales zonas y focos de actividad económica, con especial referencia al territorio español y europeo. Observación e identificación de los paisajes geográficos resultantes.

Bloque 3. Organización política y espacio geográfico.

- La organización política de las sociedades. Diferentes tipos de regímenes políticos. Identificación de los principios e instituciones de los regímenes democráticos.

- La organización política y administrativa de España. La diversidad geográfica. Desequilibrios regionales.

- El espacio geográfico europeo. Organización política y administrativa de la Unión Europea. Funcionamiento de las instituciones.

- Localización y caracterización de los grandes ámbitos geopolíticos, económicos y culturales del mundo.

Bloque 4. Transformaciones y desequilibrios en el mundo actual.

- Interdependencia y globalización. 
- Desarrollo humano desigual. Actitud critica frente al desigual reparto del desarrollo y rechazo de las desigualdades entre las personas y los pueblos del mundo. Políticas de cooperación.

- Tendencias y consecuencias de los desplazamientos de población en el mundo actual. Análisis de la situación en España y en Europa.

- Riesgos y problemas medioambientales. Medidas correctoras y políticas de sostenibilidad. Disposición favorable para contribuir, individual y colectivamente, a la racionalización en el consumo y al desarrollo humano de forma equitativa y sostenible. (ESPAÑA, 2007a, p. 707).

O bloco 1 permanece com sua característica procedimental visando a desenvolver praticamente todas as competências básicas, mas especialmente as de tratamento da informação e digital, de comunicação lingüística e a competência para aprender a aprender. Os blocos 2 e 3, de caráter mais conceitual, estão voltados especialmente para o desenvolvimento das competências social e cidadã e sobre o conhecimento e a interação com o mundo físico.

Em comparação com o decreto anterior, a principal diferença é que lá não havia esse bloco de caráter procedimental. Houve também uma inversão de conteúdos. Os temas de Geografia Urbana, que no decreto anterior estavam no terceiro curso, neste aparecem no segundo. Os conteúdos de Geografia Política, que no decreto anterior estavam no segundo curso, neste aparecem no terceiro, como se pode ver acima (bloco 3).

O quarto curso, como no decreto 3473/2000, é dedicado integralmente aos conteúdos tradicionalmente ensinados pela História. No bloco 1 são listados conteúdos de caráter procedimental de História e História da Arte. O bloco 2 "Bases históricas de la sociedad actual" - está voltado para a compreensão das transformações políticas e econômicas desde o absolutismo até o franquismo, passando pela revolução industrial. O bloco 3 é dedicado ao estudo do mundo atual: a ordem política e econômica do pós-guerra, os blocos de poder, a transição para a democracia na Espanha, a construção da União Européia, a Espanha e a UE hoje, a globalização e os novos centros de poder etc. Deve ser dito que o estudo desse temário não é exclusivo da História, pode ser feito também pela Geografia, como ocorre no Brasil, por exemplo.

Excetuando a introdução do bloco 1, de caráter procedimental, os conteúdos dos outros três blocos não são muito diferentes dos temas ensinados sob 
a vigência do decreto 3473/2000. Entretanto, houve uma mudança significativa: a retirada do item "La vida moral e a reflexión ética" que vinha sendo ensinado no quarto curso da ESO desde o decreto 1007/1991. Esse tema foi incorporado pela "Educação para a cidadania e os direitos humanos", nova disciplina introduzida no currículo de acordo com o artigo 24.3 da LOE: "En uno de los tres primeros cursos [ESO] todos los alumnos cursarán la matéria de educación para la ciudadania y los derechos humanos en la que se prestará especial atención a la igualdad entre hombres y mujeres." (ESPAÑA, 2006a, p. 17170).

Embora não seja objeto de estudo desta pesquisa, gostaria de lembrar que a introdução dessa nova disciplina, assim como das competências básicas, segue orientação do Conselho da Europa e é motivo de acirrados debates na Espanha. Sua justificativa é atacar a alienação política dos jovens, mas há pessoas à direita e à esquerda do espectro político que se colocam contra essa nova disciplina, como se depreende da fala de Romero Morante e Luis Gómez (2008, p. 16):

Mientras que a instancias de la OCDE y el Consejo de Europa, preocupados por la desafección política de los jóvenes, bastantes países están introduciendo algún tipo de educación para la ciudadania en la periferia de sus cirrícula escolares - no sin polémica $y$, en algunos casos, haciendo tabla rasa de riquísimos desarrollos previos $[\ldots]$

\section{BACHILLERATO}

As mais recentes enseñanzas mínimas do bachillherato foram definidas pelo Decreto Real 1467 de 2 de novembro de 2007, com base no artigo 6.2 da LOE. A Geografia continua sendo ensinada apenas no $2^{\circ}$ curso do bachillerato para a modalidade "Humanidades y Ciencias Sociales" e ainda assim não como matéria obrigatória para todos as opções de curso desta área. No Instituto San Isidro, por exemplo, na opção "Humanidades", uma das três opções de curso daquela modalidade, a Geografia aparece como disciplina optativa. Só é oferecida como disciplina obrigatória nas opções "Geografía e Historia" e "Administración y 
Gestión"117. Portanto, a Geografia continua tendo uma oferta muito limitada e um caráter meramente propedêutico. Seu currículo continua fortemente influenciado pelas $P A U$, que permanecem como única via de acesso à universidade.

O conteúdo continua enciclopédico, muito extenso para as 4 horas semanais de que dispõe a Geografia do $2^{\circ}$ bachillerato, como se observa na lista a seguir.

\section{Contenidos}

\section{Contenidos comunes:}

- El territorio: espacio en el que interactúan las sociedades. Variables geográficas que intervienen en los sistemas de organización del territorio. Elaboración y comunicación de síntesis explicativas.

- Identificación y explicación causal de localizaciones y distribuciones espaciales de fenómenos. Análisis de consecuencias.

- Búsqueda, obtención y selección de información relevante para el conocimiento geográfico: observación directa, fuentes cartográficas, estadísticas, visuales, bibliográficas y procedentes de las tecnologías de la información y la comunicación.

- Las técnicas cartográficas: planos y mapas y sus componentes. Obtención e interpretación de la información cartográfica. Cálculos y medidas, representación gráfica.

- Corrección en el lenguaje y utilización adecuada de la terminología específica.

- Responsabilidad en el uso de los recursos y valoración de las pautas de comportamiento individual y social respecto a la protección y mejora del medio ambiente.

\section{España en Europa y en el mundo:}

- España: situación geográfica; posición y localización de los territorios, factores de unidad y diversidad. Ordenación territorial: procesos históricos y ordenación político-administrativa actual.

- España en Europa. Estructura territorial. Contrastes físicos y socioeconómicos. Políticas regionales y de cohesión territorial. La posición de España en la Unión Europea.

- España en el mundo. Globalización y diversidad en el mundo: procesos de mundialización y desigualdades territoriales. Grandes ejes mundiales. Posición relativa de España en las áreas socioeconómicas y geopolíticas mundiales.

\section{Naturaleza y medio ambiente en España:}

- El medio natural español: diversidad geológica, morfológica, climática, vegetativa e hídrica. Los grandes conjuntos naturales españoles: elementos y tipos principales. Repercusiones en sus usos.

- Naturaleza y recursos: recursos hidráulicos, materias primas y recursos energéticos.

117 Instituto de Educación Secundaria San Isidro. Bachillerato: modalidades. Disponível em: $<$ www.educa.madrid.org/web/ies.sanisidro.madrid/bachilleratos.htm>. Acesso em: 3 set. 2008. 
- Naturaleza y medio ambiente: situación, condicionantes y problemas. Políticas españolas y comunitarias de protección, conservación y mejora.

- La interacción naturaleza/sociedad. El papel de los factores políticos, socio-económicos, técnicos y culturales en la configuración y transformación de los espacios geográficos.

\section{Territorio y actividades económicas en España:}

- Identificación de los problemas básicos de las actividades económicas en España y de las dinámicas a que están dando lugar. Localización y valoración de los desequilibrios que se producen en su reparto.

- Los espacios rurales: transformación de las actividades agrarias y pluralidad de tipologías espaciales. Dinámicas recientes del mundo rural. La situación española en el contexto de la Unión Europea.

- Los recursos marinos, la actividad pesquera y la acuicultura.

- Los espacios industriales. Reestructuración industrial y tendencias actuales. El sector secundario español en el marco europeo.

- Los espacios de servicios: terciarización de la economía; heterogeneidad y el desigual impacto territorial. Los transportes y las comunicaciones: incidencia en la vertebración territorial. Los espacios turísticos: factores, regiones e impacto.

- Repercusiones ambientales y sociales de las actividades económicas. Producción y consumo racional.

\section{Población, sistema urbano y contrastes regionales en España:}

- La población: distribución espacial; dinámica demográfica natural; movimientos migratorios. Crecimiento demográfico y desigualdades espaciales Estructura demográfica actual y perspectivas. La importancia de la inmigración.

- El sistema urbano: morfología y estructura. Huella de la historia y transformaciones recientes: la vida en las ciudades. Red urbana: jerarquía y vertebración.

- Los contrastes territoriales: diferencias espaciales; demográficas y socioeconómicas. Contrastes y desequilibrios territoriales. Políticas regionales y de cohesión. (ESPAÑA, 2007b, p. 45461).

Praticamente não há mudança em termos de conteúdo em comparação com o decreto 3474/2000. A Espanha, assim como sua inserção na União Européia e no mundo, continua sendo o foco central dos estudos de Geografia no $2^{\circ}$ bachillerato. Entretanto, os dois primeiros blocos do decreto anterior - "España en el sistema mundo" e "España en Europa" - foram condensados em apenas um, sob o título: "España en Europa y en el mundo". Na brecha que surgiu entraram os contenidos comunes, que têm um caráter procedimental e axiológico, como fica patente no trecho a seguir:

Además incorpora, en un bloque inicial que debe entenderse común al resto, aquellos procedimientos característicos del análisis geográfico y técnicas que facilitan el tratamiento de datos e informaciones, así como referencias a valores que forman al alumnado en la solidaridad, el respeto y la disposición para participar activamente en su entorno espacial y social.

(ESPAÑA, 2007b, p. 45461). 
Ou seja, apesar de não haver a separação de conteúdos, como da época da LOGSE, com base na santísima trinidad - conceitos, procedimentos e atitudes as duas últimas dimensões voltam nos chamados conteúdos comuns, que, como mencionado acima, devem "atravessar" os conteúdos conceituais. Os quatro blocos que vêm em seguida a esse trecho, em linhas gerais repetem o que existia no currículo anterior.

Segundo o decreto de mínimos do bachillerato o objeto de estudo da Geografia é o espaço, entendido como o conjunto de relações entre o território e a sociedade que nele atua, ressalvando que os processos sociais também são condicionados pelo espaço.

La Geografía estudia la organización del espacio terrestre, entendido éste como el conjunto de relaciones entre el territorio y la sociedad que actúa en él. El espacio es para la Geografía una realidad relativa, dinámica y heterogénea que resulta de los procesos protagonizados por los grupos humanos condicionados, a su vez, por el propio espacio preexistente. (ESPAÑA, 2007b, p. 45460).

Aqui o espaço não é tratado simplesmente como palco ou receptáculo, como vimos no atual currículo de Ciências Sociais, Geografia e História da ESO. Interessante, como já ocorrerá no decreto de mínimos do bachillerato criado no governo do PP - Decreto Real 3474/2000 - o documento curricular em vigor, criado sob o governo do PSOE - Decreto Real 1467/2007 - define o espaço como a relação entre a sociedade e o território ${ }^{118}$. Aliás, se observarmos novamente o trecho daquele documento no qual aparece essa definição (ver página 257), vamos perceber que é idêntico ao transcrito acima. No atual decreto de mínimos o conteúdo da Geografia também continua muito extenso, enciclopédico, não contribuindo para uma aprendizagem significativa dos temas abordados, fato que é agravado pela forma como são elaborados os exames da maioria das Pruebas de Acceso a la Universidad. Enfim, muda o partido no poder, mas a Geografia ensinada continua a mesma.

\footnotetext{
118 Apenas para fazer um contraponto e evidenciar mais uma vez os vários enfoques possíveis na Geografia, recordamos que Moraes (2000) define o território como a relação entre a sociedade e o espaço.
} 


\section{Comparação entre o Brasil e a Espanha}

No período democrático, tanto no Brasil quando na Espanha os respectivos Ministérios da Educação têm procurado ter um papel normatizador e regulador em termos curriculares em nível nacional, mas há uma razoável autonomia por parte dos estados da federação, aqui, e das Comunidades Autônomas, lá.

A LDB 9394/96 em seu artigo 26 definiu que o currículo da escola básica deve ter uma base nacional comum, complementada, em cada sistema de ensino e estabelecimento escolar, de acordo com as características regionais e locais da sociedade, da cultura, da economia e do alunado. Como definiu as DCNEM, a base nacional comum deverá compreender, pelo menos, $75 \%$ do tempo mínimo das 2400 horas da carga horária do ensino médio. Na realidade, esse limite de $75 \%$ é letra morta, até porque ninguém sabe exatamente qual é a base nacional comum diante da flexibilidade dos PCNEM. Com isso, alguns estados da federação têm procurado definir de forma mais fechada seu currículo, como fez São Paulo em 2008.

Vinte anos depois da famosa "Proposta da CENP", a Secretaria de Educação do estado de São Paulo elaborou uma nova proposta curricular (SÃO PAULO, 2008), embora o processo de elaboração desta não tenha sido democrático como o 1988 nem tenha nada de inovador. Essa proposta segue a divisão por áreas do conhecimento constantes dos PCNEM, mas separa a Matemática da área de Ciências da Natureza, Matemática e suas Tecnologias (as outras duas seguem idênticas à proposta do MEC: Linguagens, Códigos e suas Tecnologias e Ciências Humanas e suas Tecnologias). Considera as competências e as habilidades como referência para a elaboração do currículo e a articulação das disciplinas, mas não segue a matriz definida pelo MEC. Os conteúdos de Geografia também são diferentes da proposta do PCNEM e da OCEM.

$\mathrm{Na}$ Espanha, de acordo com a $L O E$, os conteúdos básicos das enseñanzas mínimas, tanto para a ESO como para o bachillerato, devem corresponder a $65 \%$ do horário escolar das Comunidades Autônomas que tenham o 
castelhano como língua oficial e a 55\% das que tenham uma língua co-oficial diferente da língua originária de Castela. Cada uma das Comunidades Autônomas tem seu próprio currículo. Após a publicação de um decreto de enseñanzas mínimas publicado no Boletín Oficial del Estado, cada uma delas publica seu próprio decreto em seu respectivo boletim oficial. Embora a maioria siga com maior ou menor fidelidade as propostas do MEC de Madri, outras fazem currículos de Geografia bem diferentes, como é o caso do País Basco e da Catalunha. Há um destaque para o estudo de temas da região e se desenvolve um ensino de caráter nacionalista. Essa é uma particularidade espanhola, que não existe no Brasil. Após a implantação do Estado das Autonomias, como resultado da abertura política e da promulgação da Constituição de 1978, o governo central precisou fazer uma série de concessões aos nacionalismos, especialmente do País Basco e da Catalunha, regiões que têm línguas próprias e um forte sentimento autonomista.

No campo curricular (ou na modalidade curricular das reformas) há muitas outras diferenças entre o Brasil e a Espanha, especialmente no que se refere à disciplina Geografia do ensino secundário, foco desta comparação. Claro que muitas dessas diferenças são conseqüência da organização estrutural diversa do sistema de ensino dos dois países, como vimos na parte II (rever quadro 9).

A principal diferença, que condiciona outras, é que no Brasil a Geografia é ministrada isoladamente em todas as três séries do ensino médio e na Espanha essa disciplina tem autonomia limitada. Aparece no currículo da ESO na área de Ciências Sociais, Geografia e História e como disciplina autônoma no bachillerato, mas apenas no $2^{\circ}$ curso e ainda assim só é oferecida aos estudantes da modalidade de Humanidades e Ciências Sociais.

Como vimos ao longo do capítulo anterior, a inserção da Geografia na área de Ciências Sociais com a intenção de supostamente fazer uma análise interdisciplinar da realidade, não se concretiza. Na prática, o que ocorre é apenas uma justaposição de conteúdos, não uma verdadeira integração, como era de se esperar. isso acaba enfraquecendo a Geografia frente às outras disciplinas, especialmente a História. Não por acaso, professores espanhóis como García 
Almiñana (2001) e Souto González (1999) defendem a autonomia da Geografia no currículo da ESO.

No Brasil, a Geografia também já esteve, durante o regime militar-civil, junto com a História na área de Estudos Sociais e sua independência no currículo após a abertura política é um dos fatores do fortalecimento da disciplina no ensino básico. E, digo mais, também na universidade. A razão de ser da maioria esmagadora dos cursos superiores de Geografia é a formação de professores para o ensino fundamental e médio. Embora muitos docentes da Universidade não dêem o devido valor aos cursos de licenciatura, à formação de professores para o ensino fundamental e médio, o fato é que se a Geografia fosse banida do currículo da escola básica, grande parte deles perderia sua função.

Outra diferença, incompreensível para quem olha desde o Brasil, diga-se de passagem, é que na Espanha os professores são licenciados em Geografia ou em História (ou ainda em História da Arte), mas, no momento de lecionarem, têm de ministrar as duas disciplinas (ou as três, já que História da Arte permanece na área de Ciências Sociais, Geografia e História). Há menos professores formados em Geografia e muitos dos que concluíram História ou História da Arte, ao ministrarem os conteúdos geográficos, o fazem de forma insuficiente, na medida em que não conhecem o arcabouço teórico-metodológico da disciplina. Essa situação contribui para enfraquecer a Geografia no currículo da ESO, que acaba ficando numa posição subalterna frente à História.

No Brasil isso foi mais bem equacionado: os professores licenciados em Geografia ministram aulas de Geografia no ensino médio, e os que se formam em História, vão dar aulas de História. Embora, saibamos que pela carência de professores de Geografia muitos licenciados de outras áreas - História, Sociologia e até Filosofia - ministrem essa disciplina. Mas isso é conjuntural, não estrutural, como na Espanha.

A mim me parece que na área de Ciências Sociais, Geografia e História do currículo da ESO espanhola impera um conceito idealista de interdisciplinaridade. Não é possível a interdisciplinaridade se realizar na pessoa de cada professor de Ciências Sociais, Geografia e História, até porque sua formação é disciplinar. 
Interdisciplinaridade é um processo coletivo, não individual, e sua implementação não prescinde das disciplinas, ao contrário, fortalece-as, ou deveria fortalecê-las. $\mathrm{Na}$ prática, o que impera no currículo da ESO é uma sobreposição entre os conteúdos de História e de Geografia, com essa disciplina permanecendo numa posição subalterna àquela.

$\mathrm{Na}$ Espanha os conteúdos de Ciências Sociais, Geografia e História, na ESO, e de Geografia, no bachillerato, são definidos pelos respectivos decretos de mínimos, o que supostamente lhe assegura mais força normativa. No Brasil os conteúdos de Geografia da educação média são definidos pelos Parâmetros Curriculares Nacionais do Ensino Médio. A diferença é que os PCNEM não têm força de lei. Como o próprio nome diz, esse documento é um parâmetro, um padrão, uma referência para o currículo a ser implantado em cada estado da federação (vale lembrar que de acordo com a LDB 9394/96 são os estados os responsáveis pelo ensino médio).

Entretanto, na Espanha, como no Brasil, há outros mediadores na definição do currículo. Um agente importante, tanto lá quanto cá, para a definição do currículo em nível nacional é o livro didático. Aqui, além dos livros didáticos há também as apostilas dos "sistemas de ensino". Mas talvez o principal agente definidor do currículo - em nível regional - seja a avaliação de conhecimentos para o acesso à universidade: lá, as Pruebas de Acceso a la Universidade (PAU); aqui, os exames vestibulares. A diferença é que $O$ vestibular tem o poder de conformar o currículo dos três anos do ensino médio, já as PAU impactam apenas os dois anos do bachillerato, que tem um caráter propedêutico. Não atingem a $E S O$, que é mais influenciada pelo decreto de mínimos e pelo livro didático. No Brasil, um agente que tem ampliado seu papel conformador do currículo, aliás, criado com essa intenção, é o ENEM. Embora sua influência não se dê diretamente no campo dos conteúdos, como ocorre com os exames vestibulares, porque o ENEM está assentado numa matriz de competências e habilidades.

Tanto as PAU, na Espanha, como os vestibulares, no Brasil, com raras exceções, não contribuem para o desenvolvimento de uma aprendizagem contextualizada e significativa. Os conteúdos de Geografia que esses exames 
induzem a serem ensinados, respectivamente no bachillerato e no ensino médio, são muito extensos e em geral distantes da realidade do aluno. Trata-se de um conteúdo enciclopédico, corográfico, mnemônico, que não contribui para a compreensão do mundo na era informacional, na sociedade do conhecimento. Esse é mais um fator para enfraquecer o potencial heurístico da Geografia, sua capacidade de explicação e seu status frente a outros campos disciplinares do currículo.

No Brasil, o ENEM pretende ser uma referência nacional para um ensino contextualizado, interdisciplinar e assentado na solução de situações-problemas, com base em uma matriz de competências e habilidades. Resta saber qual será o resultado do enfrentamente entre o potencial indutor da transformação desse tipo de prova externa e a resistência da "gramática escolar", própria do sistema de ensino.

No caso da Espanha o peso conformador do currículo é muito mais supranacional. A influência maior vem da União Européia, responsável pelo quadro das competências-chave na qual os espanhóis se basearam para definir as competências básicas inseridas nas enseñanzas mínimas a partir da LOE. O PISA tem causado uma certa comoção em parte da população espanhola por causa da posição inferior do país em comparação aos países mais ricos da União Européia (rever figura 2), mas sua capacidade de conformação curricular é limitada. Esse exame externo, elaborado pela OCDE só é realizado a cada três anos e o número de participantes é reduzido. Na Espanha não há um exame nacional nos moldes do ENEM brasileiro. Assim o país segue com um currículo mais orientado pelo decreto de mínimos e pelos livros didáticos, em nível nacional; em nível regional, pelas particularidades e, às vezes, suscetibilidades das Comunidades Autônomas, dentro da margem de manobra que lhes cabe; e no que tange ao bachillerato, especialmente pelas PAU.

Tanto no Brasil como na Espanha, a Geografia teve um caráter mnemônico e corográfico (típico da Geografia tradicional) dos anos 1970 até o início dos 1980 quando então se inicia um processo de renovação. Lá, induzido pela produção universitária e pelos MRP; aqui, pela produção acadêmica e por alguns livros didáticos inovadores. Algumas propostas oficiais, como a da CENP (SÃO 
PAULO, 1988), também tentaram induzir a renovação. Entretanto, tanto cá como lá, talvez mais lá do que cá, o ensino de Geografia de forma geral ainda segue fortemente conteudista, dificultando o desenvolvimento de um ensino inovador.

Quanto aos conceitos-chave da disciplina, aqui no Brasil eles foram definidos pelos PCNEM de 1999, depois esmiuçados pelos PCN + de 2002 e, finalmente, contrariados e modificados pelas OCEM de 2006. Este último documento, como vimos no capítulo anterior, deixa de trabalhar com o conceito espaço geográfico e passa a falar em espaço e tempo como categorias (rever quadros 12 e 13), o que dificulta a operacionalização pelos professores de Geografia. Fica evidente um conflito de diferentes visões teórico-metodológicas do campo disciplinar, que, entretanto, não ajuda muito o trabalho cotidiano do professor de ensino médio em sala de aula.

$\mathrm{Na}$ Espanha nunca houve uma maior preocupação pela definição explícita dos conceitos-chave da Geografia, talvez pelo fato de que essa disciplina não tenha uma identidade clara na ESO. Os conceitos são dados sem discussão, sem explicitação, parecem um tanto reificados, não permitem que aflore o debate teóricometodológico. Na Geografia do bachillerato do currículo da LOGSE, o espaço é considerado um conceito central, mas não é definido. No bachillerato do Partido Popular, o espaço é considerado como uma construção social, mas não há uma preocupação em melhor defini-lo. Nesse currículo de Geografia menciona-se ainda os conceitos de território e sociedade, entretanto, sem serem definidos.

Sob a $L O E$, o currículo de Geografia da ESO trata o espaço como palco, como receptáculo, portanto, separado da sociedade que o construiu. No bachillerato o espaço é definido como um conjunto de relações entre o território e a sociedade. Tanto nesse como naquele nível de ensino não há um quadro de conceitos-chave, como ocorre no Brasil com os PCNEM e as OCEM, não há uma clara definição conceitual, portanto, nem conflitos teóricos-metodológicos, como ocorrem aqui. O fato é que sem conceitos claramente definidos e coerentes, a capacidade de uma ciência interpretar o mundo fica limitada. A Geografia ainda assegurou plenamente isso: nem lá, nem cá. 
$\mathrm{Na}$ Espanha, a reforma mais recente passa a falar em competências básicas (nenhuma reforma anterior tratou desse tema). A LOE introduz nos currículos mínimos as competências com base no quadro de referência definido pelo programa Educação e Formação 2010 do Conselho de Educação da União Européia (ver quadro 14). Trata-se de oito competências básicas que deverão ser desenvolvidas em todas as disciplinas do currículo da ESO.

No Brasil as competências foram introduzidas pelos PCNEM. Há competências de representação e comunicação, de investigação e compreensão e de contextualização sociocultural. No documento há um quadro com essas 3 competências, que, por sua vez, articulam nove habilidades genéricas para as Ciências Humanas e suas Tecnologias (BRASIL, 1999, p. 39). Há também quadros com as habilidades específicas para cada uma das disciplinas da área, como as nove de Geografia, articuladas pelas três competências acima (ver anexo $\mathrm{C}$ ). Nas OCEM, consta um novo quadro com seis competências que articulam doze habilidades (ver anexo D). Enfim, essa profusão e indefinição de competências cria dificuldades para sua implementação no currículo real.

Aqui há uma diferença importante em comparação com as competências em vigor na Espanha desde a LOE. Lá, como vimos no capítulo anterior, há um quadro enxuto com apenas oito competências básicas que devem ser desenvolvidas por todas as disciplinas da ESO (ver página 263).

No Brasil, em termos de princípios, o que se aproxima mais do quadro de competências da União Européia, no qual a Espanha se baseou para construir o seu, são as cinco competências do ENEM (ver página 203). Elas, juntamente com as 21 habilidades que articulam, são válidas para todas as disciplinas do ensino médio. Como vimos, o ENEM pretende ter um papel conformador do currículo em nível nacional, entretanto, sua matriz de competências é diferente do quadro de competências proposto pelo PCNEM e pela OCEM.

Em meio a esses conflitos e indefinições, o currículo real segue sendo definido pelos professores em seu trabalho cotidiano na sala de aula, tendo como referência muito mais o livro didático - em nível nacional - e o exame vestibular da 
universidade pública mais concorrida da cidade, estado ou região, do que os documentos oficiais. 


\section{(IN)CONCLUSÕES}

Com esse título inusitado, fecho este trabalho buscando manter a coerência com o subtítulo "reformareformareforma...", que utilizei na abertura do primeiro capítulo. Com esse neologismo, gostaria de indicar, por um lado, que o processo de reformas educacionais é inconclusivo e, por outro, que ao final cheguei a uma conclusão de certa forma aporética, a uma "inconclusão". O fato de utilizar uma palavra que não consta do dicionário para o título de encerramento serve também para indicar dificuldades lógicas e existenciais de encontrar soluções para os problemas educacionais levantados ao longo da pesquisa. Entretanto, a solução da aporia, como já nos mostrou Habermas, não se encontra apenas na teoria, no plano da lógica, mas na prática, no plano da existência. A vida é dialética, e o método adotado busca apreender isso. O próprio devir aponta as saídas; cabe ao sujeito, especialmente ao pesquisador, interpretá-las. Assim, não teria despendido tanto papel e tinta, tempo e palavras, se não acreditasse que existem soluções para os problemas apontados ao longo deste trabalho. Para ser coerente com o método de abordagem adotado, vou apontar algumas saídas que penso ter encontrado, mesmo que sejam apenas para o debate. Tenho consciência de que mudanças na realidade educacional são processos políticos e sociais complexos. Evidentemente não ousarei apontar nenhuma solução para os problemas espanhóis, o que seria pretensão desmesurada, nos dois sentidos que essa palavra tem na língua de Cervantes. A análise do sistema educativo espanhol é necessária para que possamos ver em perspectiva os problemas do sistema educacional brasileiro.

As reformas educacionais são, por definição, um processo inconclusivo como vimos ao longo da análise dos processos reformistas do Brasil e da Espanha porque a História é movimento e a Educação, como um processo práxico, é um "quefazer" permanente. Como a escola expressa as relações dialéticas educaçãosociedade-cultura, sempre será cobrada por mudanças, por adaptações, especialmente no que tange ao currículo, ainda mais na era informacional, quando $o$ conhecimento tornou-se um recurso extremamente valorizado. 
Por mais que haja fatores específicos de cada formação sócio-espacial que contribuem para maior recorrência de reformas, como é evidente no caso da Espanha com o antagonismo bipartidário e o hecho religioso, os fatores que induzem a mudanças nos sistemas educativos são globais, internacionais. Estão ligados ao momento de aceleração próprio da atual revolução tecnológica que vivenciamos em todos os setores da vida, em todos os países, em maior ou menor grau. Na tentativa de apreender isso e, ao mesmo tempo, induzir e/ou justificar as reformas, as "comunidades epistêmicas" criam expressões - ou se apropriam das já existentes - como sociedade do conhecimento, revolução do conhecimento, produção pós-industrial, globalização, competência... tão presentes nos documentos analisados. Entretanto, para que esses conceitos tenham potencial heurístico, para que nos auxiliem a compreender o mundo do presente e, conseqüentemente, a tomar decisões que orientem o futuro, torna-se necessário desvendar seu papel prescritivo e dissimulador.

Por exemplo, por enquanto o que temos é somente uma economia do conhecimento, tal o grau de instrumentalização do conhecimento socialmente produzido, visto como recurso para valorizar o capital - produtos, processos produtivos e território - e para alimentar disputas hegemônicas no interior de cada campo disciplinar e entre cada um deles. Para nos convertermos em uma verdadeira sociedade do conhecimento, é necessário que o saber socialmente produzido seja democratizado, seja acessível a todos os membros de cada formação sócioespacial, beneficiando todas as pessoas, independentemente de classe, gênero ou etnia. O conhecimento deve deixar de ser um poderoso instrumento de poder na economia e na academia. Mais que isso, deve deixar de ser um mecanismo de criação e perpetuação de desigualdades sociais.

A definição de competência segue na mesma direção. Esse conceito não pode ser instrumentalizado pelo capital, pelo sistema produtivo, pensado apenas como meio de aumentar a competitividade entre os trabalhadores, por empregos, e entre as empresas, por mercados. Deve ser pensado como meio de, em conjunto com os conteúdos de cada campo disciplinar, aumentar a compreensão do mundo do presente, permitindo, assim, melhor inserção nele, seja como trabalhador, seja 
como cidadão, enfim, como pessoa humana integral. Como a própria etimologia da palavra pessoa aponta, cada ser humano apresenta variadas faces, desempenha diversos papéis sociais. A discussão sobre conhecimento e competência nos remete à reflexão sobre o ensino médio, especialmente de sua modalidade curricular.

No ensino médio brasileiro há um ramo propedêutico de fato, reservado à minoria que estuda em escolas privadas, basicamente de classe média, e um ramo "propedêutico" reservado à maioria, a parcela mais pobre dos estudantes, que freqüenta escolas públicas. Da forma como está organizado, o ensino médio acaba contribuindo para a manutenção dos mecanismos de perpetuação das desigualdades sociais. Os estudantes de escolas privadas de ensino médio são a maioria dos ingressantes nas universidades públicas. Já os estudantes de escolas públicas, sem preparo adequado, não conseguem ingressar num curso superior, e os que conseguem vão, em sua maioria, para instituições privadas. O vestibular das universidades públicas tem excluído majoritariamente os estudantes oriundos das escolas públicas.

Como vimos, na conformação do currículo da educação média há uma mediação fortemente instrumental, os exames vestibulares no Brasil e as pruebas de acceso a la universidad na Espanha. Esses exames são bastante conteudistas e enciclopedistas. Isso dificulta a inovação do ensino em geral e da Geografia em particular e mesmo o desenvolvimento de processos de interdisciplinaridade, tanto no Brasil como na Espanha. Porém, no Brasil o vestibular ainda cumpre um papel seletivo, perpetuador das assimetrias sociais.

É importante que a educação média regular ofereça um ensino que propicie aos alunos uma formação geral para a vida e a cidadania, como pregam os documentos oficiais do MEC, mas também é preciso que tenham a opção de uma formação profissional que thes permita ingressar no mercado de trabalho. Como vimos, a dimensão conceitual da qualificação continua sendo necessária e a dimensão experimental, associada à competência, ganha importância depois que se está inserido no mercado.

Nesse sentido, o modelo em vigor no sistema educativo espanhol pode ser inspirador. Como vimos, lá há um tronco comprensivo, obrigatório e gratuito, que 
se estende até os 16 anos; em seguida, no ensino secundário pós-obrigatório, os estudantes podem seguir dois itinerários, um claramente propedêutico, outro profissionalizante. No Brasil, com a aprovação da Lei 11274, em 2006, o ensino fundamental passou a ter nove anos e, com isso, o tronco comum da escola básica (fundamental e médio) foi ampliado para 12 anos. Entrar na escola com 6 anos converge com os sistemas de ensino dos países desenvolvidos, como o espanhol, entretanto isso "obriga" os alunos das escolas públicas a permanecerem mais tempo no sistema de ensino sem que Ihes seja oferecida uma real possibilidade de inserção no mercado de trabalho ao final desse período, nem preparo suficiente para ingressar nos cursos superiores públicos. Tendo em vista essa realidade, seria melhor que os alunos da escola pública entrassem no ensino fundamental com 6 anos de idade, cumprissem oito anos de ensino fundamental, como era antes da Lei 11274, e depois quatro anos de ensino médio (um a mais do que hoje). Desses quatros anos do ensino médio, em três os estudantes teriam uma formação básica, igual para todos, completando 11 anos de ensino comum. No último ano, poderiam ser criados dois itinerários: um propedêutico e outro profissionalizante. Isso poderia abrir um canal formal de inserção dos jovens no mercado de trabalho, especialmente para os estudantes das camadas mais pobres da sociedade, que precisam trabalhar mais cedo, e paralelamente a possibilidade de melhor preparação para aqueles que pretendem prestar vestibular. Essa medida não contraria o Decreto 5154, de 2004, que regulamentou o $\S 2^{\circ}$ do artigo 36 e os artigos 39 a 41 da LDB 9394/96. Esse decreto prevê que a educação profissional técnica pode ser oferecida de forma integrada, concomitante ou subseqüente ao ensino médio regular, mas sem exceder a carga de 800 horas anuais (2400 horas nos três anos do curso), como prega o inciso I do artigo 24 da LDB. Isso apenas convergiria para uma realidade que já existe nos CEFET, nos quais a educação média profissionalizante integrada dura quatro anos, e no final os alunos saem com o certificado de conclusão do ensino médio e o diploma de técnico.

Nos três primeiros anos do ensino médio continuaria existindo o núcleo comum, composto pelas disciplinas básicas, para todos os estudantes do sistema, como é hoje. No último ano, para o itinerário propedêutico, poderia haver uma 
diferenciação por meio da qual os alunos optariam por disciplinas específicas em função do curso superior a ser prestado. No outro itinerário, a profissionalização poderia ser oferecida em parceria com empresas, sindicatos e outras entidades da sociedade, em função das necessidades da região. Isso abriria uma porta para a entrada dos jovens no mercado de trabalho. Como vimos, no Brasil a oferta de cursos profissionalizantes ainda é muito baixa.

Da forma como está organizado o ensino regular público atualmente, os jovens permanecem 12 anos no sistema - para os que conseguem chegar até o final do ensino médio - sem ter nenhuma profissão que os habilite a ingressar no mercado de trabalho e, ao mesmo tempo, sem preparo suficiente para disputar uma vaga nas universidades públicas - as mais concorridas - em pé de igualdade com os estudantes oriundos das escolas privadas, que tiveram um ensino de fato propedêutico. Essas opções provavelmente dariam mais estímulo aos estudantes para que permanecessem na escola, reduzindo a evasão do ensino médio público.

Embora tenha consciência das dificuldades de modificar leis, de mexer em uma estrutura tão complexa, não poderia, tendo em vista as constatações da pesquisa, deixar de expressar minha posição sobre essa questão. Com isso, mantenho a coerência com o método de abordagem adotado, no qual reflexão e ação ocorrem simultaneamente, não sendo aceita, portanto, a separação sujeitoobjeto, teoria-prática. Como mencionei na introdução, fiz colégio técnico e por isso sei da importância de uma profissão para se inserir no mercado de trabalho. Embora tenha desistido de ser agrimensor, muitos dos meus colegas ganham a vida com a profissão para a qual estudaram no colégio. Sei também a falta que faz a formação básica propiciada pelas disciplinas comuns. Até hoje tenho lacunas de formação geral, porque na época o ensino profissionalizante era regulado pela LDB 5692/71, e as matérias técnicas ocupavam o lugar das disciplinas comuns. Por exemplo, tive Geografia em apenas um ano de todo o curso colegial. Assim, o ideal seria conciliar a formação comum com a profissionalização, o que já é previsto pela LDB 9394/96 e pela Lei 5154. Isso poderia contribuir para que mais estudantes das escolas públicas concluíssem o ensino médio e assegurar uma real opção de formação profissional. 
Ao facilitar a entrada dos jovens no mercado de trabalho, colaboraria para reduzir os altos índices de desemprego nessa faixa de estudos, como vimos na tabela 7.

$\mathrm{Na}$ Espanha, a escola pública tem se enfraquecido e há uma tendência de os setores mais aquinhoados da sociedade matricularem seus filhos nas escolas privadas ou nas "concertadas", criando os "centros bolha" de que falou Fernández Enguita (2008), e de os pobres ficarem nas escolas públicas, os "centros gueto", que, além do aspecto socioeconômico, têm um componente étnico, já que os pobres são crescentemente os imigrantes, em especial os latino-americanos.

Ouve-se muito que a Espanha serviu de referência para a reforma brasileira ${ }^{119}$, mas parece que, nesse caso, é o Brasil que está sendo referência para os espanhóis. Claro, isso é apenas uma ironia, uma vez que esse cenário é fruto das contradições da sociedade espanhola, que corre o risco de avançar em direção a uma realidade que é bem conhecida nossa. Há tempos convivemos com escolas "bolha" e escolas "gueto", especialmente nos grandes centros urbanos, onde a desigualdade socioeconômica é gritante. Cumpre lembrar que a oposição "bolha" versus "gueto" ocorre em outros setores de nossa sociedade. Essa dicotomia é muito presente em nossa formação sócio-espacial, sendo bem visível nas paisagens urbanas, especialmente das metrópoles: "condomínios fechados" versus "favelas", "shopping centers" versus "camelôs", "carro blindado" versus "ônibus lotado" etc. Portanto, seria de estranhar que essa oposição não se manifestasse também na Educação, que é um subsistema da sociedade. É por isso que as reformas educacionais têm muito pouco poder para transformar a sociedade, daí seu caráter lampedusiano, como falam os espanhóis. O sistema educativo - a forma como está estruturado, sua organização curricular, suas relações de poder, sua inserção social - é reflexo do momento histórico da sociedade que o produziu.

Como diz Fernandez Enguita (2008), a vanguarda da sociedade do conhecimento, na Espanha, está cada vez mais concentrada na escola privada. Isso não é diferente no Brasil. Assim, os sistemas de ensino público, tanto lá quanto cá -

\footnotetext{
11 De fato os documentos espanhóis foram uma das referências para a reforma curricular no Brasil, especialmente da educação fundamental. Isso é visível, por exemplo, no linguajar dos PCN de ensino fundamental II, no qual há a separação dos conteúdos em conceitos, procedimentos e atitudes - divisão que os espanhóis chamam de "santíssima trindade" - como está em Coll (1991) e nos decretos de "enseñanzas mínimas" derivados da LOGSE.
} 
mais cá do que lá -, correm o risco de produzir "novos" analfabetos. Não mais aquele que não domina as letras, o alfabeto, como o "analfabeto" da origem etimológica; não mais apenas aquele que não entende, não interpreta as informações, como o "analfabeto funcional"; mas, cada vez mais, aquele que não sabe produzir e utilizar conhecimentos, o "analfabeto informacional". Em outras palavras, o problema no momento presente não é mais dominar a sintática, as letras; nem mesmo a semântica, o texto; mas participar das relações simbólicas, dominar o contexto. É isso que cada vez mais se coloca como necessidade na sociedade do conhecimento. Imagine então o que significa o fato de $1 \mathrm{em}$ cada 10 brasileiros com mais de 15 anos ainda serem simples e etimologicamente analfabetos. Isso dá uma medida dos desafios da sociedade brasileira, especialmente de seu sistema de ensino público, na transição para a era informacional, para uma sociedade do conhecimento democrática.

$\mathrm{Na}$ análise da modalidade curricular das reformas, percebe-se que a Geografia tem uma presença maior no ensino médio brasileiro, no qual aparece nos três anos, do que na ESO espanhola, na qual está diluída na área de Ciências Sociais, Geografia e História, e no bachillerato, em que aparece apenas no $2^{\circ}$ curso da modalidade Humanidades e Ciências Sociais. Como apontei no capítulo 2 da parte III, creio que isso contribui para enfraquecer a Geografia espanhola como campo disciplinar autônomo.

No Brasil, a Geografia é ensinada de forma autônoma no currículo do ensino médio - está presente também em todos os anos do ensino fundamental - e isso é um dos motivos de sua força como campo disciplinar, até mesmo na Universidade. A Geografia universitária brasileira é um campo disciplinar vigoroso e reconhecido internacionalmente. Por exemplo, Horacio Capel, que está para a Geografia espanhola como Milton Santos está para a brasileira, já expressou verbalmente isso mais de uma vez. Entretanto, para a Geografia ganhar mais vigor, tanto a produzida na universidade como a ensinada na escola básica, para ampliar seu potencial heurístico, sua capacidade de compreensão do mundo, de interpretação das relações sócio-espaciais, é fundamental que defina com clareza sua fundamentação teórico-metodológica, seja ela qual for. A pluralidade 
metodológica lhe fortalece, desde que defina com clareza e coerência seus conceitos e categorias. Isso é fundamental também para revigorar sua posição no ensino básico, especialmente no médio, já que a Geografia da escola básica se alimenta da produção da Geografia acadêmica. Além disso, essa é responsável pela formação dos professores de ensino fundamental e médio e pela definição do currículo da escola básica.

Não vou retomar o que foi apontado na análise das contradições e incoerências das propostas curriculares de Geografia dos documentos dos PCNEM e especialmente da OCEM, no capítulo I da parte III. Gostaria apenas de frisar que as críticas apontam caminhos e são um passo necessário para encontrá-los. Somente o avanço das pesquisas, a reflexão e o debate entre o MEC, os elaboradores dos documentos, a Universidade - de onde eles provêm -, os autores de livros didáticos e os professores do ensino médio, poderão definir os caminhos com maior clareza.

Uma questão parece certa: seja lá qual for o caminho a ser trilhado - e não existe apenas um -, com o advento da chamada sociedade do conhecimento, a Geografia também está sendo instada a rever seus conteúdos e, mais do que isso, seu arcabouço teórico-metodológico, para garantir sua capacidade explicativa e, conseqüentemente, seu lugar como disciplina escolar relevante. Para isso, torna-se fundamental, além da definição clara e coerente de conceitos e categorias, a seleção de conteúdos significativos, o levantamento de informações relevantes, que possam embasar a produção de conhecimentos geográficos, possibilitando aos alunos melhor compreensão do mundo em que vivemos da perspectiva desse campo disciplinar. Ou seja, a Geografia tem muito a contribuir para a construção de uma sociedade do conhecimento democrática.

Com base na análise da Educação no tempo presente, não vislumbro como o sistema educacional, da forma como está organizado na Espanha e especialmente no Brasil, possa contribuir para a real emancipação dos sujeitos envolvidos na relação ensino-aprendizagem. Não vejo muitas possibilidades de as reformas educacionais analisadas contribuírem efetivamente para a emancipação dos sujeitos aos quais preferencialmente se destinam: professores e alunos das 
milhares de escolas espalhadas pelo território desses dois Estados nacionais. É evidente que, ao dizer isso, não estou pensando a emancipação como revolução do proletariado, como o fizeram Marx e Engels e também Adorno e Horkheimer, até sucumbirem à aporia. Nem mesmo os partidos de origem operária que estão no poder no Brasil - o PT - e na Espanha - o PSOE - pensam a emancipação dessa perspectiva. Ou seja, adaptaram seu discurso e sua prática ao momento presente, à conjuntura. Além disso, a escola historicamente tem cumprido um papel mais conservador que transformador da realidade, especialmente se pensarmos a transformação como uma ruptura política e socioeconômica, como é próprio das revoluções sociais. De forma geral, a escola tende a perpetuar o status quo, não a transformá-lo. Nesse sentido, como apontaram diversos autores espanhóis - na Espanha esse debate é muito mais intenso -, as reformas educacionais têm muito mais um caráter lampedusiano.

Mesmo que reconceituemos a emancipação, como fez Habermas para escapar da aporia em que se meteram Adorno e Horkheimer, sob o marco do Estado democrático de direito, sob a perspectiva da ação comunicativa, ainda assim fica difícil vislumbrar sua realização sob os sistemas de ensino do momento presente nos países analisados. Isso é especialmente verdadeiro para o Brasil, país em que os problemas socioeconômicos e, conseqüentemente, educacionais são proporcionais ao seu tamanho demográfico e territorial.

Apesar de todas as diferenças que observamos ao longo deste trabalho, o que há em comum nas reformas educacionais elaboradas no Brasil e na Espanha, após os respectivos processos de abertura política, é que elas têm sido orientadas por um interesse técnico, mesmo sob governos de esquerda, mesmo quando falam em emancipação. A intenção que move essas reformas é o controle, a organização curricular calcada no/a discurso/prática de ensino eficaz, de objetivos de aprendizagem, de resultados, e não na formação de pessoas verdadeiramente emancipadas.

Os professores da educação média não têm um efetivo protagonismo nesses processos reformistas, não participam ativamente da elaboração das propostas curriculares produzidas sempre por docentes do ensino superior, em geral 
distantes da realidade da escola básica. Assim, essas propostas chegam prontas aos professores do ensino médio, por mais que o linguajar utilizado, cheio de eufemismos e passivizações, diga que não. Por exemplo, quando uma reforma curricular com caráter prescritivo, como as Orientações Curriculares para o Ensino Médio de 2006 - a prescrição está presente inclusive no linguajar com uso recorrente do verbo "dever" -, fala em emancipação do professor, é, no mínimo, uma profunda contradição. Como o professor se emancipará sob o jugo de reformas feitas de cima para baixo, da qual ele não se sente protagonista?

As reformas analisadas, tanto no Brasil como na Espanha, são orientadas por um interesse técnico, não primam pela dialogicidade como propugnaram tanto Paulo Freire quanto Jürgen Habermas, portanto pouco podem contribuir para o processo de emancipação dos sujeitos envolvidos na relação ensino-aprendizagem - professores e alunos.

A Educação tem sido fortemente instrumentalizada pelos interesses do capital, do sistema produtivo, do mercado; tem sido fortemente pressionada a dar respostas às necessidades do atual regime de acumulação, às demandas do capitalismo informacional-global. Em grande medida, a pessoa foi subsumida pelo trabalhador e há um déficit de cidadania, especialmente no Brasil, onde a desigualdade social é muito pronunciada. Como conseqüência, pode-se dizer que tanto aqui como na Espanha o potencial emancipador da Educação tem sido bloqueado por essa instrumentalização, pela hegemonia do interesse técnico em detrimento do interesse emancipador. A escola, como está estruturada, especialmente no Brasil, tem contribuído mais para a perpetuação de uma realidade marcada por assimetrias sociais e oportunidades desiguais do que para sua superação.

Mas, como a emancipação é um processo a ser conquistado e como a vida sócio-histórica é dialética, a própria escola pode ser o locus de enfrentamento dessas contradições, dessa aporia. Assim, a Educação como parte da sociedade é dialética: ao mesmo tempo que tem um papel conservador, hegemônico, também tem, embora cheio de limitações, um papel transformador. Aí reside a esperança, porque pior do que estar numa escola instrumentalizada é estar fora de qualquer 
escola. Para isso, entretanto, é preciso também haver uma revisão do conceito de emancipação, talvez de uma perspectiva mais realista, mais terrena.

No Brasil de hoje ainda é premente conquistar a emancipação dos primórdios da razão iluminista (nem Horkheimer, Adorno ou Habermas negaram sua importância, apenas criticaram sua faceta instrumental), como a libertação das injunções da natureza, a libertação das arbitrariedades, a consolidação plena da democracia e do Estado de direito, a garantia do respeito aos direitos e deveres da cidadania, o acesso a conquistas básicas da modernidade, como saúde pública universal, educação pública, gratuita e de qualidade para todos; enfim, a libertação propiciada pela razão moderna, que entre nós ainda é só um projeto.

Para não abrir demais o leque, fiquemos apenas no campo educacional. $\mathrm{Na}$ Educação, a emancipação passa pela formação de alunos e alunas verdadeiramente críticos e autônomos, portanto preparados para enfrentar os desafios da sociedade contemporânea como trabalhadores, cidadãos e especialmente como pessoas integrais. Para isso, é fundamental que a educação escolar como um todo, e cada disciplina em particular, como a Geografia, Ihes proporcione o domínio de conhecimentos - conceitos e competências - que possibilitem a compreensão do mundo em que vivemos segundo o recorte epistemológico de cada um dos campos disciplinares do currículo, ainda que possa ser de forma interdisciplinar.

É importante que os estudantes-cidadãos-trabalhadores-pessoas saiam da menoridade intelectual, libertem-se das parcialidades da ignorância. Para tanto, a Educação no país deveria ser prioridade máxima, a começar pelo fortalecimento da escola pública, na qual se deveria oferecer um ensino de boa qualidade problematizador e crítico - para todos os estudantes, independentemente de sua origem socioeconômica ou étnica, e não apenas um ensino voltado para a formação de trabalhadores para suprir o mercado. Embora, como apontamos, não se possa desprezar essa vertente da formação pessoal. Enfim, a escola pública deveria propiciar uma Educação verdadeiramente democrática e esclarecedora que, portanto, pudesse contribuir para a desalienação, para a compreensão do momento 
presente, para a inserção no mundo do trabalho e para a consolidação da cidadania, em resumo, para a libertação.

Hoje em dia esse é o significado de emancipação para grandes parcelas da sociedade brasileira que permanecem excluídas das conquistas básicas da modernidade, muitas ainda mergulhadas no obscurantismo do iletramento em plena era informacional, com graves déficits de conhecimento e, conseqüentemente, de qualificação e de cidadania. No futuro, a emancipação certamente será outra. Como nos lembra Freire (2005), a Educação é um "quefazer" permanente, por causa da inconclusão dos homens e do devenir da realidade, e necessariamente problematizadora, porque comprometida com a mudança.

Pensar que não há uma saída é não pensar dialeticamente. Lembremos que Habermas apontou caminhos para superar a aporia de Adorno e Horkheimer. Entretanto, esses caminhos não foram apontados de forma idealista pelo pensamento do filósofo, mas de forma práxica. Ou seja, os caminhos são apontados pelo pensamento, pela reflexão, mas em relação dialética com a realidade, com a prática. Noutras palavras, os caminhos são apontados pela práxis. A saída efetivamente se dará pela relação dialética entre as pessoas e o mundo vivido.

Talvez a "emancipação" seja a "utopia" da modernidade. Ao apontar um futuro melhor, encoraja as pessoas e os grupos sociais na luta permanente pela transformação da injusta realidade presente. 


\section{REFERÊNCIAS BIBLIOGRÁFICAS}

ABBAGNANO, Nicola. Diccionario de Filosofía. 3. ed. México, D.F.: Fondo de Cultura Económica, 1998.

ADORNO, Theodor W. Educação e emancipação. 3. ed. Rio de Janeiro: Paz e Terra, 2003.

ADORNO, Theodor W.; HORKHEIMER, Max. Dialética do esclarecimento: fragmentos filosóficos. Rio de Janeiro: Jorge Zahar, 1985.

APPLE, Michael W. Ideologia e currículo. 3. ed. Porto Alegre: Artmed, 2006.

ARON, Raymond. O marxismo de Marx. 2. ed. São Paulo: Arx, 2005.

ARROYO LLERA, Fernando. La formación de profesores de geografía en el nuevo plan de estudios de la convergencia europea. Íber Didáctica de las Ciencias Sociales, Geografía e Historia, Barcelona, n. 42, año X, p. 76-87. Octubre 2004. ASOCIACIÓN DE GEÓGRAFOS ESPAÑOLES. La Geografía en los libros de textos de enseñanza secundaria. Madrid: AGE, 2000. Disponível em: <http://age.ieg.csic.es/docs/00-12-libros-text.PDF>. Acesso em: 6 ago. 2008. ASSOCIAÇÃO BRASILEIRA DE NORMAS TÉCNICAS. NBR 6023: informação e documentação: referências: elaboração. Rio de Janeiro, 2002a.

ASSOCIAÇÃO BRASILEIRA DE NORMAS TÉCNICAS. NBR 10520: informação e documentação: citações em documentos: apresentação. Rio de Janeiro, 2002b.

ASSOCIAÇÃO BRASILEIRA DE NORMAS TÉCNICAS. NBR 14724: informação e documentação: trabalhos acadêmicos: apresentação. Rio de Janeiro, 2005.

BAUD, Pascal et al. Dicionário de Geografia. Lisboa: Plátano Edições Técnicas, 1999.

BELL, Daniel. El advenimiento de la sociedad post-industrial: un intento de prognosis social. 6. ed. Madrid: Alianza Editorial, 2006.

BELTRÁN DUARTE, Remedios. Función del discurso en las reformas

educativas: principios y contexto escola en la ESO. Málaga: Universidad de Málaga, 2000. (Estudios y ensayos, 40).

BRANDÃO, Carlos da Fonseca. LDB passo a passo: Lei de Diretrizes e Bases da Educação Nacional (Lei n. 9394/96), comentada e interpretada, artigo por artigo. 3. ed. São Paulo: Avercamp, 2007.

BRASIL. Constituição da República Federativa do Brasil de 1988. Presidência da República. Casa Civil. Subchefia para Assuntos Jurídicos, Brasília, 1988. Disponível em: <www.planalto.gov.br/ccivil_03/Constituicao/Constituiçao.htm>. Acesso em: 10 set. 2008. 
BRASIL. Decreto n. 2208, de 17 de abril de 1997. Regulamenta o $\S 2^{\circ}$ do art. 36 e os arts. 39 a 42 da Lei n. 9394, de 20 de dezembro de 1996, que estabelece as diretrizes e bases da educação nacional. Presidência da República. Casa Civil. Subchefia para Assuntos Jurídicos, Brasília, 1997. Disponível em: <www.planalto.gov.br/ccivil_03/decreto/D2208.htm>. Acesso em: 2 out. 2008.

BRASIL. Decreto n. 5154, de 23 de julho de 2004. Regulamenta o $\S 2^{\circ}$ do art. $36 \mathrm{e}$ os arts. 39 a 41 da LDB 9394, de 20 de dezembro de 1996, que estabelece as diretrizes e bases da educação nacional, e dá outras providências. Presidência da República. Casa Civil. Subchefia para Assuntos Jurídicos, Brasília, 2004b. Disponível em: <www.planalto.gov.br/Ccivil_03/_Ato2007-2010/2007/Lei/L11494.htm>. Acesso em: 2 out. 2008.

BRASIL. Lei n. 4024, de 20 de dezembro de 1961. Fixa as Diretrizes e Bases da Educação Nacional. Presidência da República. Casa Civil. Subchefia para Assuntos Jurídicos, Brasília, 1961. Disponível em: <www.planalto.gov.br/ccivil_03/LEIS/L4024.htm>. Acesso em: 10 set. 2008.

BRASIL. Lei n. 5692, de 11 de agosto de 1971. Fixa Diretrizes e Bases para o ensino de $1^{\circ}$ e $2^{\circ}$ graus, e dá outras providências. Presidência da República. Casa Civil. Subchefia para Assuntos Jurídicos, Brasília, 1971. Disponível em: <www.planalto.gov.br/ccivil_03/LEIS/L5692.htm>. Acesso em: 10 set. 2008.

BRASIL. Lei n. 7044, de 18 de outurbro de 1982. Altera dispositivos da Lei n. 5692, de 11 de agosto de 1971 , referentes a profissionalização do ensino de $2^{\circ}$ grau. Presidência da República. Subchefia para Assuntos Jurídicos, Brasília, 1982. Disponível em: <www.planalto.gov.br/ccivil_03/Leis/L7044.htm>. Acesso em: 23 set. 2008.

BRASIL. Lei n. 9394, de 20 de dezembro de 1996. Estabelece as Diretrizes e Bases da Educação Nacional. Presidência da República. Casa Civil. Subchefia para Assuntos Jurídicos, Brasília, 1996. Disponível em: <www.planalto.gov.br/ccivil_03/LEIS/l9394.htm>. Acesso em: 10 set. 2008.

BRASIL. Lei n. 11494, de 20 de junho de 2007. Regulamenta o Fundo de Manutenção e Desenvolvimento da Educação Básica e de Valorização dos Profissionais da Educação - FUNDEB. Presidência da República. Casa Civil. Subchefia para Assuntos Jurídicos. Brasília, 2007. Disponível em: <www.planalto.gov.br/Ccivil_03/_Ato2007-2010/2007/Lei/L11494.htm>. Acesso em: 10 set. 2008.

BRASIL. Ministério da Educação. Secretaria de Educação Média e Tecnológica. Parâmetros curriculares nacionais do ensino médio: ciências humanas e suas tecnologias. Brasília: MEC; SEMTEC, 1999. (vol. 4).

BRASIL. Ministério da Educação. Secretaria de Educação Média e Tecnológica. Parâmetros curriculares nacionais: ensino médio. Brasília: MEC; SEMTEC, 2002a. 
BRASIL. Ministério da Educação. Secretaria de Educação Média e Tecnológica.

Ciências humanas e suas tecnologias. Brasília: MEC; SEMTEC, 2002b. (PCN + ensino médio: orientações complementares aos parâmetros curriculares nacionais).

BRASIL. Ministério da Educação. Secretaria de Educação Básica. Orientações curriculares do ensino médio. Brasília: MEC; SEB, 2004a. Disponível em: <http://portal.mec.gov.br>. Acesso em: 21 jun. 2005.

BRASIL. Ministério da Educação. Secretaria de Educação Básica. Ciências humanas e suas tecnologias. Brasília: MEC; SEB, 2006. (Orientações curriculares para o ensino médio; vol. 3).

BRASIL. Portaria Ministerial n. 438, de 28 de maio de 1998. Ministério da Educação e do Desporto, Brasília, 1998. Disponível em: <www.inep.gov.br/basica/ enem/legislacao/p438_280598.htm>. Acesso em: 23 set. 2008.

BRASIL. Presidência da República. Secretaria de Imprensa. Discurso do presidente da República, Luiz Inácio Lula da Silva, na cerimônia de sanção de projetos de lei na área de educação: piso salarial nacional dos professores e programa de apoio a planos de reestruturação e expansão das universidades federais - Reuni. Brasília, 16 jul. 2008. Disponível em:

$<w w w . i n f o . p l a n a l t o . g o v . b r / d o w n l o a d / d i s c u r s o s / p r 784-2 @ . d o c>$. Acesso em: 26 set. 2008.

BRASLAVSKY, Cecilia; COSSE, Gustavo. Las actuales reformas educativas en América Latina: cuatro actores, tres lógicas y ocho tensiones. REICE - Revista electrónica iberoamericana sobre calidad, eficacia y cambio en educación, Madrid, v. 4, n. 2e, p. 1-26, 2006. Disponível em: <www.rinace.net/vol4num2e.htm>. Acesso em: 28 jul. 2007.

BRUNET, Roger et al. Les mots de la géographie: dictionnaire critique. 3. ed. Montpellier-Paris: Reclus, 2005.

CACETE, Núria Hanglei. A AGB, os PCNs e os professores. In: CARLOS, Ana Fani Alessandri; OLIVEIRA, Ariovaldo Umbelino de (Orgs.). Reformas no mundo da educação: parâmetros curriculares e geografia. São Paulo: Contexto, 1999. p. 36-42.

CAPEL, Horacio; LUIS, Alberto; URTEAGA, Luis. La geografía ante la reforma educativa. Geocrítica: cuadernos críticos de geografía humana, Barcelona, n. 53, sep. 1984.

CAPEL, Horacio. La didáctica de las ciencias sociales en la educación básica española. Una tesis doctoral sobre el diseño curricular de ciencias sociales en la educación secundaria obligatoria. Biblio 3W - Revista bibliográfica de Geografía y Ciencias Sociales, Barcelona, n. 49, 30 sep. 1997. Disponível em: <www.ub.es/geocrit/b3w-49.htm>. Acesso em: 4 set. 2007.

CASASSUS, Juan. A reforma educacional na América Latina no contexto da globalização. Cadernos de pesquisa, São Paulo, n. 114, p. 7-28, nov. 2001. Disponível em: <www.scielo.br/pdf/cp/n114/a01n114.pdf>. Acesso em: 28 jul. 2007. 
CASTELAR, Sonia Maria Vanzella. O ensino de geografia e a formação docente. In: CARVALHO, Anna Maria Pessoa de (Coord.). Formação continuada de professores: uma releitura das áreas de conteúdo. São Paulo: Pioneria Thomson Learning, 2003. p. 103-121.

CASTELLS, Manuel. A sociedade em rede. 3. ed. São Paulo: Paz e Terra, 2000. (A era da informação: economia, sociedade e cultura; v. 1).

CASTELLS, Manuel. A sociedade em rede. 7. ed. São Paulo: Paz e Terra, 2003. (A era da informação: economia, sociedade e cultura; v. 1).

CASTRO, Jorge Abrahão de. Financiamento e gasto público na educação básica no Brasil: 1995-2005. Educação \& Sociedade, Campinas, vol. 28, n. 100, Especial, p. 857-876. out. 2007. Disponível em: <www.scielo.br>. Acesso em: 19 set. 2008.

CHEPTULIN, Alexandre. A dialética materialista: categorias e leis da dialética. São Paulo: Alfa-Ômega, 1982.

CHESNAIS, François. A mundialização do capital. São Paulo: Xamã, 1996.

CHIZZOTTI, Antonio. Pesquisa em ciência humanas e sociais. 6. ed. São Paulo: Cortez, 2003.

CLIMENT LÓPEZ, Eugenio. Las pruebas de acceso a la universidad y la enseñanza de la Geografía en el Bachillerato español. In: MARRÓN GAITE, María Jesús (Ed.). La formación geográfica de los ciudadanos en el cambio de milenio. Madrid: Asociación de Geógrafos Españoles; Associação de Professores de Geografia de Portugal; Universidad Complutense de Madrid, 2001.

COLL, César. Psicologia y Currículum: una aproximacion psicopedagógica a la elaboración del currículum escolar. Barcelona: Paidós, 1991.

COLL, César. La reforma del Sistema Educativo Español: la calidad de la enseñanza como objetivo. Quito: Instituto Fronesis/Libresa, 1992.

COMISIÓN EUROPEA. Eurybase. La base de datos sobre los sistemas educativos de Europa. Organización del sistema educativo español, 2007/2008. Madrid: Dirección General de Educación y Cultura. 2008. Disponível em: $<$ www.mepsyd.es/cide/espanol/investigacion/sistemaeducativo/files/Eurybase.pdf>. Acesso em: 22 out. 2008.

COMISSÃO DAS COMUNIDADES EUROPÉIAS. Proposta de recomendação do Parlamento Europeu e do Conselho sobre as competências-chave para a aprendizagem ao longo da vida. Bruxelas: Comissão Européia, 2005. (European Commission. Education \& Training). Disponível em:

$<$ http://ec.europa.eu/education/policies/2010/doc/keyrec_pt.pdf>. Acesso em: 1 set. 2008.

CONSELHO DA UNIÃO EUROPÉIA. Relatório do Conselho (Educação) para o Conselho Europeu: "Os objetivos futuros concretos dos sistemas de educação e formação". Bruxelas: Comissão Européia, 2001. (European Commission. Education \& Training). Disponível em: 
$<$ http://ec.europa.eu/education/policies/2010/doc/rep_fut_obj_pt.pdf $>$. Acesso em: 1 set. 2008.

CORRÊA, Roberto Lobato. Espaço, um conceito-chave da Geografia. In: CASTRO, Iná Elias de; GOMES, Paulo Cesar da Costa; CORRÊA, Roberto Lobato (Org.).

Geografia: conceitos e temas. Rio de Janeiro: Bertrand Brasil, 1995.

DELORS, Jacques (coord.). Educação: um tesouro a descobrir. Relatório para a UNESCO da Comissão Internacional sobre Educação para o século XXI. 6. ed. São Paulo: Cortez; Brasília: MEC; UNESCO, 2001.

DESCARTES, René. Discurso del método. Meditaciones metafísicas. 14. ed. México D.F.: Espasa-Calpe Mexicana, 1978.

DIEESE - Departamento Intersindical de Estatísticas e Estudos Socioeconômicos. Anuário da qualificação social e profissional 2007. São Paulo: DIEESE, 2007. Disponível em: <www.mte.gov.br/dados_estatisticos/anuario_qual_prof.asp >. Acesso em: 19 set. 2008.

DRUCKER, Peter. Sociedade pós-capitalista. 6. ed. São Paulo: Pionera. 1997. DUROZOI, Gérard; ROUSSEL, André. Dicionário de filosofia. 2. ed. Campinas: Papirus, 1996.

EAGLETON, Terry. Ideologia. Uma introdução. São Paulo: Editora UNESP; Boitempo, 1997.

ECO, Umberto. O professor aloprado. Entrevistador: Juan Cruz. Folha de S. Paulo, São Paulo, 11 maio 2008, p. 6. Mais!

EINSTEIN, Albert. A teoria da relatividade especial e geral. Rio de Janeiro: Contraponto, 1999.

ENGELS, Friedrich. A dialética da natureza. 6. ed. Rio de Janeiro: Paz e Terra, 2000.

ENGELS, Friedrich. Anti-Dühring: filosofia, economia política, socialismo. 3. ed. Rio de Janeiro: Paz e Terra, 1990.

ESCAMILLA, Amparo; LAGARES, Ana Rosa. La LOE: perspectivas pedagógicas e histórica. Glosario de términos esenciales. Barcelona: Graó, 2006.

ESCUDERO, Juan Manuel (coord.). Diseño y desarrollo del curriculum en la educación secundaria. Barcelona: ICE Universitat de Barcelona; Editorial Horsori, 1997. p. 19-46.

ESPAÑA. Constitución Española de 1978: aprobada por las cortes en sesiones plenarias del Congreso de los Diputados y del Senado celebradas el 31 de octubre de 1978. Madrid: Imprensa Nacional del Boletín Oficial del Estado, 1996.

ESPAÑA. Jefatura del Estado. Ley 14/1970, de 4 de agosto, General de Educación y Financiamiento de la Reforma Educativa. Boletín Oficial del Estado, Madrid, n. 187, p. 12525-12546, 6 ago. 1970. Disponível em: <www.boe.es/g/es>. Acesso em: 2 out. 2008. 
ESPAÑA. Jefatura del Estado. Ley Orgánica 8/1985, de 3 de julio, Reguladora del Derecho a la Educación. Boletín Oficial del Estado, Madrid, n. 159, p.

21015-21022, 4 jul. 1985. Disponível em: <www.boe.es/g/es>. Acesso em: 2 out. 2008.

ESPAÑA. Jefatura del Estado. Ley Orgánica 1/1990, de 3 de octubre, de Ordenación General del Sistema Educativo. Boletín Oficial del Estado, Madrid, n. 238, p. 28927-28942, 4 oct. 1990. Disponível em: <www.boe.es/g/es>. Acesso em: 2 out. 2008.

ESPAÑA. Jefatura del Estado. Ley Orgánica 10/2002, de 23 de diciembre, de Calidad de la Educación. Boletín Oficial del Estado, Madrid, n. 307, p. 45188-45202, 4 dic. 2002. Disponível em: <www.boe.es/g/es>. Acesso em: 2 out. 2008.

ESPAÑA. Jefatura del Estado. Ley Orgánica 2/2006, de 3 de mayo, de Educación. Boletín Oficial del Estado, Madrid, n. 106, p. 17158-17207, 4 mayo 2006a. Disponível em: <www.boe.es/g/es>. Acesso em: 2 out. 2008.

ESPAÑA. Ministerio de Educación y Ciencia. Real Decreto 1007/1991, de 14 de junio, por el que se establecen las enseñanzas mínimas correspondientes a la educación secundaria obligatoria. Boletín Oficial del Estado, Madrid, n. 152, p. 21193-21195, 26 jun. 1991a. Disponível em: <www.boe.es/g/es>. Acesso em: 2 out. 2008.

ESPAÑA. Ministerio de Educación y Ciencia. Real Decreto 1007/1991, de 14 de junio, por el que se establecen las enseñanzas mínimas correspondientes a la educación secundaria obligatoria. Boletín Oficial del Estado, Madrid, suplemento $n$. 152, anexo I, p. 41-46, 26 jun. 1991b. Disponível em: <www.boe.es/g/es>. Acesso em: 2 out. 2008.

ESPAÑA. Ministerio de Educación y Ciencia. Real Decreto 1178/1992, de 2 de octubre, por el que se establecen las enseñanzas mínimas del bachillerato. Boletín Oficial del Estado, Madrid, n. 253, anexo I, p. 35583-35585, 21 oct. 1992a. Disponível em: <www.boe.es/g/es>. Acesso em: 2 out. 2008.

ESPAÑA. Ministerio de Educación y Ciencia. Real Decreto 1178/1992, de 2 de octubre, por el que se establecen las enseñanzas mínimas del bachillerato. Boletín Oficial del Estado, Madrid, suplemento n. 253, anexo I, p. 40-42, 21 oct. 1992b. Disponível em: <www.boe.es/g/es>. Acesso em: 2 out. 2008.

ESPAÑA. Ministerio de Educación, Cultura y Deporte. Real Decreto 3473/2000, de 29 de diciembre, por el que se modifica el Real Decreto 1007/1991, de 14 de junio, por el que se establecen las enseñanzas mínimas correspondientes a la educación secundaria obligatoria. Boletín Oficial del Estado, Madrid, n. 14, p. 1810-1858, 16 enero 2001a. Disponível em: <www.boe.es/g/es>. Acesso em: 2 out. 2008.

ESPAÑA. Ministerio de Educación, Cultura y Deporte. Real Decreto 3474/2000, de 29 de diciembre, por el que se modifican el Real Decreto 1700/1991, de 29 de noviembre, por el que se establece la estructura del bachillerato, y el Real Decreto 1178/1992, de 2 de octubre, por el que se establecen las enseñanzas mínimas del 
bachillerato. Boletín Oficial del Estado, Madrid, n. 14, p. 1858-1922, 16 enero 2001b. Disponível em: <www.boe.es/g/es>. Acesso em: 2 out. 2008.

ESPAÑA. Ministerio de Educación y Ciencia. Una educación de calidad para todos y entre todos: propuestas para el debate. Madrid: Secretaría General de Educación, 2004. Disponível em: <www.mec.es>. Acesso em: 21 jun. 2005.

ESPAÑA. Ministerio de Educación y Ciencia. Secretaría General de Educación. Ley Orgánica 2/2006, de 3 de mayo, de Educación; Ley Orgánica 8/1985, de 3 de julio, Reguladora del Derecho a la Educación. Madrid: Ministerio de Educación y Ciencia, 2006b.

ESPAÑA. Ministerio de Educación y Ciencia. Real Decreto 1631/2006, de 29 de diciembre, por el que se establecen las enseñanzas mínimas correspondientes a la educación secundaria obligatoria. Boletín Oficial del Estado, Madrid, n. 5, p. 677-773, 5 enero 2007a. Disponível em: <www.boe.es/g/es>. Acesso em: 2 out. 2008.

ESPAÑA. Ministerio de Educación y Ciencia. Real Decreto 1467/2007, de 2 de noviembre, por el que se establecen la estructura del bachillerato y se fijan sus enseñanzas mínimas. Boletín Oficial del Estado, Madrid, n. 266, p. 45381-45477, 6 nov. 2007b. Disponível em: <www.boe.es/g/es>. Acesso em: 2 out. 2008.

ESPAÑA. Ministerio de Educación y Ciencia. Secretaría General Técnica. Datos Básicos de la Educación en España en el Curso 2007/2008. Madrid: Secretaría General Técnica, 2007c.

ESPAÑA. Ministerio de Educación y Ciencia. Secretaría General de Educación. Instituto de Evaluación. Panorama de la Educación. Indicadores de la OCDE 2007. Informe Español. Madrid: Secretaría General Técnica, 2007d.

FAIRCHILD, Henry Pratt (ed.). Diccionario de Sociología. 2. ed. México, D.F.: Fondo de Cultura Económica, 1997.

FERNANDES, Florestan (Org.). Marx / Engels. 3. ed. São Paulo: Ática, 2003. (Grandes cientistas sociais, 36).

FERNÁNDEZ ENGUITA, Mariano. En defensa de la educación pública amenazada. El País, Madrid, p. 14, 17 jun. 2002. Opinión.

FERNÁNDEZ ENGUITA, Mariano. Igualdad, equidad, solidariedad. In: ALANíS FALANTES, Leonardo (coord.). Debate sobre la ESO: luces y sombras de uma etapa educativa. Madrid: Universidad Internacional de Andalucía: Akal, 2003. p. 17-34.

FERNÁNDEZ ENGUITA, Mariano. Educar em tempos incertos. Porto Alegre: Artmed, 2004.

FERNÁNDEZ ENGUITA, Mariano. La escuela a examen: un análisis sociológico para educadores y otras personas interesadas. Madrid: Ediciones Pirámide, 2006a.

FERNÁNDEZ ENGUITA, Mariano. Iguales, ¿Hasta dónde? Complejidades de la justicia educativa. In: GIMENO SACRISTÁN, José (Comp). La reforma necesaria: 
entre la política educativa y la práctica escolar. Madrid: Ediciones Morata, 2006b. p. 81-93.

FERNÁNDEZ ENGUITA, Mariano. Escuela pública y privada en España: la segregación rampante. Profesorado - Revista de currículum y formación del profesorado, Granada, v. 12, n. 2, jun.jul. 2008. p. 1-28.

FREIRE, Paulo. Pedagogia do oprimido. 44. ed. Rio de Janeiro: Paz e Terra, 2005. FREIRE, Paulo. Pedagogia da esperança. 13. ed. Rio de Janeiro: Paz e Terra, 2006.

FREITAG, Barbara. A teoria crítica: ontem e hoje. São Paulo: Brasiliense, 2004.

FRIGOTTO, Gaudêncio. Educação e a crise do capitalismo real. 5. ed. São Paulo: Cortez, 2003.

GARCÍA ALMIÑNANA, Eugenio. La Geografía, en la reforma de la reforma: sus consecuencias en los niveles de la ESO y bachillerato. In: MARRÓN GAITE, María Jesús (Ed.). La formación geográfica de los ciudadanos en el cambio de milenio. Madrid: Asociación de Geógrafos Españoles; Associação de Professores de Geografia de Portugal; Universidad Complutense de Madrid, 2001.

GARCÍA ALMIÑANA, Eugenio. La Geografía en el actual bachillerato español. In: MARRÓN GAITE, María Jesús et al. (Ed.). La enseñanza de la geografía ante las nuevas demandas sociales. Toledo: Grupo de Didáctica de la Geografía (AGE); Universidad de Castilla-La Mancha; Escuela Universitaria de Magisterio de Toledo, 2003.

GARCIA, Bianco Zalmora. Escola pública, ação dialógica e ação comunicativa: a radicalidade democrática em Paulo Freire e Jürgen Habermas. São Paulo: FEUSP, 2005. Originalmente apresentada como tese de doutorado, Faculdade de Educação da Universidade de São Paulo, 2005.

GARCÍA DE CORTÁZAR, Fernando; GONZÁLEZ VESGA, José Manuel. Breve Historia de España. Madrid: Alianza Editorial, 1994. (Humanidades).

GARDNER, Howard. Inteligências múltiplas: a teoria na prática. Porto Alegre: Artmed, 2000.

GARDNER, Howard. Ml after twenty years. Cambridge: Howardgardner.com, 2006. Disponível em: <www.howardgardner.com/Papers/papers.html>. Acesso em: 12 mar. 2008.

GHIRALDELLI Jr., Paulo. Neopragmatismo, Escola de Frankfurt e Marxismo. Rio de Janeiro: DP\&A, 2001.

GIMENO SACRISTÁN, José. De las reformas como política a las políticas de reforma. In: GIMENO SACRISTÁN, José. (Comp). La reforma necesaria: entre la política educativa y la práctica escolar. Madrid: Ediciones Morata, 2006. p. 23-42.

GIMENO SACRISTÁN, José. 0 currículo: uma reflexão sobre a prática. 3. ed. Porto Alegre: Artmed, 2000. 
GIMENO SACRISTÁN, José. Poderes instáveis em educação. Porto Alegre: Artmed, 1999.

GOODSON, Ivor F. Currículo: teoria e história. 7. ed. Petrópolis, RJ: Vozes, 2005. GORZ, André. O imaterial: conhecimento, valor e capital. São Paulo: Annablume, 2005.

GRUNDY, Shirley. Producto o praxis del curriculum. 2. ed. Madrid: Ediciones Morata, 1994.

GUIJARRO GUTIÉRREZ, Alfonso. El peso del pasado. Posibilidade y límites de algunas propuestas innovadoras para la enseñanza de las Ciencias Sociales en la Educación Secundária Obligatoria. Con-Ciencia Social, Madrid, n. 1, p. 13-49, año 1997.

HABERMAS, Jürgen; HALLER, Michael [entrev.]. Passado como futuro. Rio de Janeiro: Tempo Brasileiro, 1993. (Tempo universitário, 94).

HABERMAS, Jürgen. Técnica e ciência como "ideologia". Lisboa: Edições 70, 1994.

HABERMAS, Jürgen. Teoría de la acción comunicativa, I. Racionalidad de la acción y racionalización social. 4. ed. Madrid: Taurus Humanidades, 2003.

HABERMAS, Jürgen. Diagnósticos do tempo: seis ensaios. Rio de Janeiro: Tempo Brasileiro, 2005. (Biblioteca Colégio do Brasil, 11).

HARGREAVES, Andy. 0 ensino na sociedade do conhecimento: educação na era da insegurança. Porto Alegre: Artmed, 2004.

HARVEY, David. A justiça social e a cidade. São Paulo: Hucitec, 1980.

HARVEY, David. A condição pós-moderna: uma pesquisa sobre as origens da mudança cultural. 2. ed. São Paulo: Edições Loyola, 1993.

HAWKING, Stephen W. Uma breve história do tempo: do big bang aos buracos negros. 2. ed. Rio de Janeiro: Rocco, 1988.

HORKHEIMER, Max. Teoria tradicional e teoria crítica. In: Walter Benjamim, Max Horkheimer, Theodor W. Adorno, Jürgen Habermas. São Paulo: Abril Cultural, 1980a. (Os Pensadores). p. 117-154.

HORKHEIMER, Max. Filosofia e teoria crítica. In: Walter Benjamim, Max

Horkheimer, Theodor W. Adorno, Jürgen Habermas. São Paulo: Abril Cultural, 1980b. (Os Pensadores). p. 155-161.

HOUAISS: dicionário da língua portuguesa. Rio de Janeiro: Instituto Antonio Houaiss; Editora Objetiva, 2008. Disponível em:

<http://houaiss.uol.com.br/busca.jhtm>. Acesso em: 10 set. 2008.

IANNI, Octavio. Nação: província da sociedade global? In: SANTOS, Milton et al. (Orgs.). Território: globalização e Fragmentação. São Paulo: Hucitec; Anpur, 1994. IAROZINSKI, Maristela Heideman. Contribuições da teoria da ação comunicativa de Jürgen Habermas para a educação tecnológica. Curitiba: CEFET-PR, 2000. 
Originalmente apresentada como dissertação de mestrado, Centro Federal de Educação Tecnológica do Paraná, 2000.

INEP - Instituto Nacional de Estudos e Pesquisas Educacionais Anísio Teixeira. Exame Nacional do Ensino Médio (Enem): documento básico. Brasília : MEC/INEP, 1998. Disponível em: <www.enem.inep.gov.br/arquivos/Docbasico.pdf>. Acesso em: 25 set. 2008.

INEP - Instituto Nacional de Estudos e Pesquisas Educacionais Anísio Teixeira. Exame Nacional do Ensino Médio (Enem): fundamentação teórico-metodológica. Brasília : O Instituto, 2005. Disponível em: <www.publicacoes.inep.gov.br>. Acesso em: 25 set. 2008.

INEP - Instituto Nacional de Estudos e Pesquisas Educacionais Anísio Teixeira. Investimentos Públicos em Educação. Brasília, 2008. Disponível em: <www.inep.gov.br/estatisticas/gastoseducacao>. Acesso em: 25 set. 2008.

INEP - Instituto Nacional de Estudos e Pesquisas Educacionais Anísio Teixeira. Sinopse estatística da educação básica - 1991-1995. Brasília: O Instituto, 2003. Disponível em: <www.inep.gov.br/basica/censo/Escolar/Sinopse/sinopse.asp>. Acesso em: 10 set. 2008.

INEP - Instituto Nacional de Estudos e Pesquisas Educacionais Anísio Teixeira. Sinopse estatística da educação básica 2005. Brasília: O Instituto, 2006. Disponível em: <www.inep.gov.br/basica/censo/Escolar/Sinopse/sinopse.asp>. Acesso em: 10 set. 2008.

INEP - Instituto Nacional de Estudos e Pesquisas Educacionais Anísio Teixeira. Sinopse estatística da educação básica 2006. Brasília: O Instituto, 2007a. Disponível em: <www.inep.gov.br/basica/censo/Escolar/Sinopse/sinopse.asp>. Acesso em: 25 set. 2008.

INEP - Instituto Nacional de Estudos e Pesquisas Educacionais Anísio Teixeira. Sinopse estatística da educação superior - graduação 2006. Brasília: O Instituto, 2007b. Disponível em: $<$ www.inep.gov.br/basica/censo/Escolar/Sinopse/sinopse.asp >. Acesso em: 10 set. 2008.

JAPIASSU, Hilton; MARCONDES, Danilo. Dicionário básico de filosofia. 4. ed. Rio de Janeiro: Jorge Zahar, 2006.

JOHNSON, Allan G. Dicionário de Sociologia: guia prático da linguagem sociológica. Rio de Janeiro: Jorge Zahar, 1997.

JUDT, Tony. Pós-guerra: uma história da Europa desde 1945. Rio de Janeiro: Objetiva, 2008.

KEMMIS, Stephen. El curriculum: más allá de la teoría de la reproducción. 3. ed. Madrid: Ediciones Morata, 1998.

KRÜGER, Karsten. El concepto de 'sociedad del conocimiento'. Biblio 3W - Revista bibliográfica de Geografía y Ciencias Sociales, Barcelona, v. XI, n. 683, 25 oct. 2006. Disponível em: <www.ub.es/geocrit/b3w-683.htm>. Acesso em: 22 ago. 2007. 
KUENZER, Acacia (Org.). Ensino médio: construindo uma proposta para os que vivem do trabalho. 3. ed. São Paulo: Cortez, 2002.

KUMAR, Krishan. Da sociedade pós-industrial à pós-moderna: novas teorias sobre o mundo contemporâneo. Rio de Janeiro: Jorge Zahar, 1997.

LACOSTE, Yves. A Geografia - isso serve, em primeiro lugar, para fazer a guerra. Campinas: Papirus, 1988.

LÁZARO Y TORRES, María Luisa de. La Geografía en el bachillerato y en la enseñanza secundaria obligatoria. In: MARRÓN GAITE, María Jesús (Ed.). La formación geográfica de los ciudadanos en el cambio de milenio. Madrid: Asociación de Geógrafos Españoles; Associação de Professores de Geografia de Portugal; Universidad Complutense de Madrid, 2001.

LEFEBVRE, Henri. Espacio y política: el derecho a la ciudad. Barcelona: Peninsula, 1976.

LEFEBVRE, Henri. Lógica formal, lógica dialética. 5. ed. Rio de Janeiro: Civilização Brasileira,1991.

LEPARGNEUR, Hubert. Introdução aos estruturalismos. São Paulo: Herder; Edusp, 1972.

LERENA, Carlos. Formas del sistema de enseñanza: escolástico, liberal y tecnocrático. In: FERNÁNDEZ ENGUITA, Mariano. (Ed.). Sociología de la educación: lecturas básicas y textos de apoyo. Barcelona: Ariel, 1999. p. 701-720.

LEYSHON, Andrew. Annihilating space?: the speed-ip of communications. In: ALLEN, John; HAMNETT, Chris. A shrinking world? Global unevenness and inequality. Milton Keynes: the Open University; Oxford: Oxford University Press, 1995. p. 11-54.

LIPIETZ, Alain. Audácia: uma alternativa para o século 21. São Paulo: Nobel, 1991.

LOJKINE, Jean. A revolução informacional. São Paulo: Cortez, 1995.

LOPES, Alice Casimiro. Os parâmetros curriculares nacionais para o ensino médio e a submissão ao mundo produtivo: o caso do conceito de contextualização.

Educação \& Sociedade, Campinas, SP. vol. 23, n. 80, p. 389-403, set. 2002.

LOPES, Alice Casimiro. Quem defende os PCN para o Ensino Médio?. In: LOPES, Alice Casimiro; MACEDO, Elizabeth (Orgs.). Políticas de currículo em múltiplos contextos. São Paulo: Cortez, 2006. p. 126-158. (Cultura, Memória e Currículo; v.7).

LÓPEZ DOMECH, Ramón. La Geografía en la reforma de la LOGSE. In: MARRÓN GAITE, María Jesús (Ed.). La formación geográfica de los ciudadanos en el cambio de milenio. Madrid: Asociación de Geógrafos Españoles; Associação de Professores de Geografia de Portugal; Universidad Complutense de Madrid, 2001. p. 661-669.

LÓPEZ RUPÉREZ, Francisco. El legado de la LOGSE. Madrid: Gotaagota, 2006.

MAAR, Wolfgang Leo. Educação crítica, formação cultural e emancipação política na Escola de Frankfurt. In: PUCCI, Bruno (Org.). Teoria crítica e educação: a questão 
da formação cultural na Escola de Frankfurt. 3. ed. Petrópolis, RJ: Vozes; São Carlos, SP: Editora da UFSCar, 2003. p. 59-81.

MACHADO, Nílson José. Epistemologia e didática: as concepções de conhecimento e inteligência e a prática docente. 4. ed. São Paulo: Cortez, 2000.

MACHADO, Nílson José. Sobre a idéia de competência. In: PERRENOUD, Philippe et al. As competências para ensinar no século XXI: a formação dos professores e o desafio da avaliação. Porto Alegre: Artmed, 2002. p. 137-155.

MACHADO, Nílson José. Conhecimento e valor. São Paulo: Moderna, 2004. (Educação em pauta: teorias e tendências).

MANETTO, Francesco. La enseñanza más privada. El País, Madrid, p. 36, 3 oct. 2007. Sociedad.

MARCHESI, Álvaro. Controversias en la educación española. 4. ed. Madrid: Alianza Editorial, 2005.

MARCHESI, Álvaro; MARTíN, Elena. Qualidade do ensino em tempos de mudança. Porto Alegre: Artmed, 2003.

MARCONI, Marina de Andrade; LAKATOS, Eva Maria. Fundamentos de metodologia científica. 6. ed. São Paulo: Atlas, 2005.

MARINA, José Antonio. Teoria da inteligência criadora. Lisboa: Editorial Anagrama, 1995. (Caminho da ciência).

MARTINS, José de Souza. Henri Lefebvre e o retorno à dialética. São Paulo: Hucitec, 1996.

MARX, Karl. Manuscritos econômico-filosóficos e outros textos escolhidos; seleção de textos de José Arthur Gianotti. 2. ed. São Paulo: Abril Cultural, 1978. (Os Pensadores).

MARX, Karl; ENGELS, Friedrich. A ideologia alemã. Lisboa: Edições Avante, 1981. (Biblioteca do Marxismo-Leninismo, 16).

MARX, Karl; ENGELS, Friedrich. Manifesto comunista. 6. ed. São Paulo: Nova Stella, 1985.

MATA I GARRIGA, Marta. L'Escola de Mestres Rosa Sensat de Barcelona.

Perspectivas, Paris, v. XV, n. 1, 1985. Disponível em: <www.rosasensat.org>. Acesso em: 9 out. 2008.

MATTELART, Armand. Historia de la sociedad de la información. Barcelona: Paidós, 2007. (Bolsillo Paidós, 12).

MICHAELIS: moderno dicionário da língua portuguesa. São Paulo: Companhia Melhoramentos, 1998. (Dicionários Michaelis).

MORA, José Ferrater. Dicionário de filosofia. 4. ed. São Paulo: Martins Fontes, 2001. 
MORAES, Antonio Carlos Robert; COSTA, Wanderley Messias da. Geografia crítica: a valorização do espaço. 2. ed. São Paulo: Hucitec, 1987. (Teoria e realidade).

MORAES, Antonio Carlos Robert. Capitalismo, geografia e meio ambiente. São Paulo: FFLCH-USP, 2000. Originalmente apresentada como tese de livre docência, Departamento de Geografia da Faculdade de Filosofia, Letras e Ciências Humana da Universidade de São Paulo, 2000.

MORAES, Antonio Carlos Robert. Geografia: pequena história crítica. 20. ed. São Paulo: Annablume, 2005. (Geografias).

MOREIRA, Antonio Flávio; SILVA, Tomaz Tadeu da (Orgs.). Currículo, cultura e sociedade. 8. ed. São Paulo: Cortez, 2005.

MORIN, Edgar. Mal-estar de maio de 68 é ainda mais profundo hoje. Entrevistador: Samy Adghirni. Folha de S. Paulo, São Paulo, p. A14, 28 abr. 2008. Entrevista da $2^{\mathrm{a}}$.

NOBRE, Marcos. A teoria crítica. Rio de Janeiro: Jorge Zahar, 2004. (Filosofia passo-a-passo, 47).

NOBRE, Marcos. Max Horkheimer: a teoria crítica entre o nazismo e o capitalismo tardio. In: NOBRE, Marcos (Org.). Curso livre de teoria crítica. Campinas, SP: Papirus, 2008. p. 35-52.

OHMAE, Kenichi. 0 fim do Estado-nação: a ascensão das economias regionais. Rio de Janeiro: Campus, 1996.

PACHECO, José Augusto. Currículo: teoria e práxis. Porto, Portugal: Porto Editora, 1996. (Ciências da educação).

PACHECO, José Augusto. Escritos curriculares. São Paulo: Cortez, 2005.

PASSARINHO, Jarbas. Uma análise da política educacional na época do Al-5.

Folha Dirigida: especial dia do professor, Rio de Janeiro, 2001. Disponível em: $<$ www.folhadirigida.com.br/professor/Cad06/EntJarbasPassarinho.htm >. Acesso em: 24 mar. 2008.

PERRENOUD, Philippe. Construir as competências desde a escola. Porto Alegre: Artmed, 1999.

PIMENTA, Selma Garrido; GONÇALVES, Carlos Luiz. Revendo o ensino de $2^{\circ}$ grau: propondo a formação de professores. 2. ed. São Paulo: Cortez, 1992. (Magistério, $2^{\circ}$ grau).

PINO, Ivany. A Lei de Diretrizes e Bases da Educação: a ruptura do espaço social e a organização da educação nacional. In: BRZEZINSKI, Iria (Org.). LDB interpretada: diversos olhares se entrecruzam. 10. ed. São Paulo: Cortez, 2007. p. 19-42.

PINTO, José Marcelino de Rezende. O ensino médio. In: OLIVEIRA, Romualdo Portela de; ADRIÃO, Theresa (Orgs.). Organização do ensino no Brasil: níveis e 
modalidade na Constituição Federal e na LDB. 2. ed. São Paulo: Xamã, 2007. p. 47-72.

PNUD - Programa das Nações Unidas para o desenvolvimento. Relatório de Desenvolvimento Humano 2007/2008. Combater as alterações climáticas: solidariedade humana num mundo dividido. Nova York: PNUD; Coimbra: Edições Almedina, 2007.

PONTUSCHKA, Nídia Nacib. A Geografia: pesquisa e ensino. In: CARLOS, Ana Fani Alessandri (Org.). Novos caminhos da Geografia. São Paulo: Contexto, 1999a. p. 111-142. (Caminhos da Geografia).

PONTUSCHKA, Nídia Nacib. Parâmetros Curriculares Nacionais: tensão entre Estado e escola. In: CARLOS, Ana Fani Alessandri; OLIVEIRA, Ariovaldo Umbelino de (Orgs.). Reformas no mundo da educação: parâmetros curriculares e geografia. São Paulo: Contexto, 1999b. p. 11-18.

PONTUSCHKA, Nídia Nacib; PAGANELLI, Tomoko lyda; CACETE, Núria Hanglei. Para ensinar e aprender Geografia. São Paulo: Cortez, 2007. (Docência em formação; ensino fundamental).

POSTMAN, Neil. Tecnopólio: a rendição da cultura à tecnologia. São Paulo: Nobel, 1994.

PT - Partido dos Trabalhadores. Textos. Estatuto do Partido dos Trabalhadores (aprovado pelo DN em 11/03/01). Brasília, 2001. Disponível em: <www.pt.org.br/portalpt/images/stories/textos/estatutopt.pdf>. Acesso em: 21 out. 2008.

PT - Partido dos Trabalhadores. Documentos que contam a história. Manifesto de lançamento do PT. São Paulo, 10 fev. 1980. Disponível em:

<www.pt.org.br/pt25anos/anos80/documentos/80_manifesto.pdf>. Acesso em: 21 out. 2008.

PUCCI, Bruno (Org.). Teoria crítica e educação: a questão da formação cultural na Escola de Frankfurt. 3. ed. Petrópolis, RJ: Vozes; São Carlos, SP: Editora da UFSCar, 2003.

PUELLES BENITEZ, Manuel de. Los hitos reformistas: la viabilidad de las reformas y la perversión de las leyes. In: GIMENO SACRISTÁN, José (Comp.). La reforma necesaria: entre la política educativa y la práctica escolar. Madrid: Ediciones Morata, 2006. p. 61-80.

RAMOS, Marise Nogueira. A pedagogia das competências: autonomia ou adaptação? 2. ed. São Paulo: Cortez, 2002a.

RAMOS, Marise Nogueira. A educação profissional pela pedagogia das competências e a superfície dos documentos oficiais. Educação \& Sociedade, Campinas, SP. vol. 23, n. 80, p. 405-427, set. 2002b.

RAMOS, Marise Nogueira. O ensino médio ao longo do século XX: um projeto inacabado. In: STEPHANOU, Maria; BASTOS, Maria Helena Camara (Orgs.). 
Histórias e memórias da educação no Brasil, vol. III: século XX. 2. ed. Petrópolis, RJ: Vozes, 2005. p. 229-242.

REAL ACADEMIA ESPAÑOLA: diccionario de la lengua española. Madrid: RAE, 2008. Disponível em: <www.rae.es>. Acesso em: 10 set. 2008.

ROITH, Christian. La teoría crítica en la pedagogía alemana y su recepción en España. Alcalá de Henares: Universidad de Alcalá, 2005. (Ciencias de la educación, $3)$.

ROMERO MORANTE, Jesús; LUIS GOMES, Alberto. La historia del currículum y la formación del profesorado como encrucijada: por una colaboración entre la historia de la educación y una didáctica crítica de las ciencias sociales. In: JIMÉNEZ EGUIZÁBAL, A. et al. (Coords.). Etnohistoria de la escuela. XII Coloquio Nacional de Historia de la Educación. Burgos: Servicio de Publicaciones de la Universidad de Burgos; Sociedad Española de Historia de la Educación, 2003. p. 1009-1020. Disponível em: <www.ub.es/geocrit/sv-95.htm>. Acesso em: 10 set. 2008.

ROMERO MORANTE, Jesús; LUIS GOMES, Alberto. El conocimiento sóciogeográfico en la escuela: las tensiones inherentes a la transmisión institucionalizada de cultura y los dilemas de la educación para la democracia en este mundo globalizado. Scripta Nova - Revista electrónica de Geografía y Ciencias Sociales, Barcelona, v. XII, n. 270 (123), 1 agosto 2008. Disponível em:

<www.ub.es/geocrit/sn/sn-270/sn-270-123.htm>. Acesso em: 10 set. 2008.

ROSSI, Clóvis. "Casa dos Artistas" afegã. Folha de S. Paulo, São Paulo, p. A2, 20 nov. 2001. Opinião.

ROZADA, José Maria. Las reformas y lo que está pasando. Con-ciencia Social. Sevilla, n. 6, p. 15-57, 2002.

RUSSELL, Bertrand. La educación y el orden social. Barcelona: Edhasa, 2004. SANDRONI, Paulo. Novíssimo dicionário de economia. 7. ed. São Paulo: Best Seller, 2001.

SANTOS, Milton. A natureza do espaço. Técnica e tempo. Razão e emoção. São Paulo: Hucitec, 1996a.

SANTOS, Milton. Espaço do cidadão. 3. ed. São Paulo: Nobel, 1996b. (Espaços).

SANTOS, Milton. Espaço e método. 4. ed. São Paulo: Nobel, 1997. (Espaços).

SANTOS, Milton. Espaço e sociedade: ensaios. Petrópolis, RJ: Vozes, 1979.

SANTOS, Milton. Por uma Geografia nova. Da crítica da Geografia a uma Geografia crítica. 2. ed., São Paulo: Hucitec, 1980.

SANTOS, Milton. Sociedade e espaço: a formação social como teoria e como método. Boletim Paulista de Geografia, n. 54. São Paulo: AGB - Seção São Paulo, Jun. 1977.

SÃO PAULO (Estado). Secretaria da Educação. Coordenadoria de Estudos e Normas Pedagógicas. Proposta curricular para o ensino de Geografia; $1^{\circ}$ grau. São Paulo: SE/CENP, 1988. 
SÃO PAULO (Estado). Secretaria de Estado da Educação. Proposta curricular do Estado de São Paulo. Geografia: ensino fundamental - ciclo Il e ensino médio. São Paulo: SEE, 2008.

SARTRE, Jean-Paul. Crítica da razão dialética: precedido por questões de método. Rio de Janeiro: DP\&A, 2002.

SAVIANI, Demerval. A nova lei da educação: trajetória, limites e perspectivas. 9. ed. Campinas, SP: Autores Associados, 2004. (Educação contemporânea).

SAVIANI, Dermeval. Política e educação no Brasil: o papel do Congresso Nacional na legislação do ensino. 6. ed. Campinas, SP: Autores Associados, 2006. (Educação contemporânea).

SCHULTZ, Theodore W. La inversión en capital humano. In: FERNÁNDEZ ENGUITA, Mariano. (Ed.). Sociología de la educación: lecturas básicas y textos de apoyo. Barcelona: Ariel, 1999. p. 85-96.

SENE, Eustáquio de. Globalização e espaço geográfico. 3. ed. São Paulo: Contexto, 2007. (Contexto Acadêmica).

SEVERINO, Antonio Joaquim. A pesquisa em educação: a abordagem críticodialética e suas implicações na formação do educador. Contrapontos - Revista de Educação da Universidade do Vale do Itajaí. Ano I, n. 1, p. 11-22, jan./jun. 2001.

SEVERINO, Antonio Joaquim. Metodologia da pesquisa científica. 22. ed. São Paulo: Cortez, 2002.

SEVERINO, Antonio Joaquim. Os embates da cidadania: ensaio de uma abordagem filosófica da nova lei de diretrizes e bases da educação nacional. In: BRZEZINSKI, Iria (Org.). LDB interpretada: diversos olhares se entrecruzam. 10. ed. São Paulo: Cortez, 2007. p. 57-68.

SILVA, Armando Corrêa da. As categorias como fundamentos do conhecimento geográfico. In: SANTOS, Milton; SOUZA, Maria Adélia A. de (Coord.). O espaço interdisciplinar. São Paulo: Nobel, 1986.

SILVA, De Placido e. Vocabulário jurídico. 24. ed. Rio de Janeiro: Forense, 2004.

SIMON, Imre. A revolução digital e a sociedade do conhecimento. Curso ministrado no IME-USP, 1999. Disponível em: <www.ime.usp.br/ is/ddt/mac333>. Acesso: 27 jun. 2005.

SMITH, Neil. Desenvolvimento desigual: natureza, capital e a produção de espaço. Rio de Janeiro: Bertrand Brasil, 1988.

SOJA, Edward W. Geografias pós-modernas: a reafirmação do espaço na teoria social crítica. Rio de Janeiro: Jorge Zahar, 1993.

SOUSA SANTOS, Boaventura de. A crítica da razão indolente: contra o desperdício da experiência. 4. ed. São Paulo: Cortez, 2002. (Para um novo senso comum: a ciência, o direito e a política na transição paradigmática; v. 1).

SOUTO GONZÁLEZ, Xosé Manuel. ¿Qué sentido tienen la educación geográfica e histórica en el umbral del siglo XXI? Biblio 3W - Revista Bibliográfica de Geografía y 
Ciencias Sociales, Barcelona, n. 63, 9 feb. 1998. Disponível em: <www.ub.es/geocrit/ b3w-63.htm>. Acesso em: 4 set. 2007.

SOUTO GONZÁLEZ, Xosé Manuel. Didáctica de la Geografía: problemas sociales y conocimiento del medio. 2. ed. Barcelona: Ediciones del Serbal, 1999. (La estrela polar, 11)

SOUTO GONZÁLEZ, Xosé Manuel. Las reformas escolares y la geografía en el umbral del siglo XXI. In: MARRÓN GAITE, María Jesús et al. (Ed.). La enseñanza de la geografía ante las nuevas demandas sociales. Toledo: Grupo de Didáctica de la Geografía (AGE); Universidad de Castilla-La Mancha; Escuela Universitaria de Magisterio de Toledo, 2003. p. 277-298.

SOUTO GONZÁLEZ, Xosé Manuel. La Geografía escolar en el período 1990-2003. In: COMITÉ ESPAÑOL DE LA UNIÓN GEOGRÁFICA INTERNACIONAL. La

Geografía española ante los retos de la sociedad actual: aportación española al XXX Congreso de la Unión Geográfica Internacional. Madrid: Comité Español de la Unión Geográfica Internacional, 2004a.

SOUTO GONZÁLEZ, Xosé Manuel. Uma proposta para o ensino da geografia na Espanha. In: VESENTINI, José William (Org.). O ensino de geografia no século XXI. Campinas, SP: Papirus, 2004b. (Papirus Educação).

SPOSITO, Eliseu Savério. Geografia e filosofia: contribuição para o ensino do pensamento geográfico. São Paulo: Editora UNESP, 2004.

SPOSITO, Maria Encarnação Beltrão. Parâmetros Curriculares Nacionais para o ensino de geografia: pontos e contrapontos para uma análise. In: CARLOS, Ana Fani Alessandri; OLIVEIRA, Ariovaldo Umbelino de (Orgs.). Reformas no mundo da educação: parâmetros curriculares e geografia. São Paulo: Contexto, 1999. p. 19-35.

STIELTJES, Cláudio. Jürgen Habermas: a desconstrução de uma teoria. São Paulo: Germinal, 2001.

TAMBURRI, Pascual. Genocidio educativo: las víctimas y verdugos de la LOGSE. Barcelona: Áltera, 2007.

TERRÓN, Aída. Hacia una genealogía del sistema público de enseñanza español. In: BARREIRO, Herminio; TERRÓN, Aída. La institución escolar: una creación del estado moderno. Madrid: MEC; Octaedro; Fies, 2006. (La escuela del nuevo siglo, 1).

THOMPSON, John B. Ideologia e cultura moderna: teoria social crítica na era dos meios de comunicação de massa. 4. ed. Petrópolis, RJ: Vozes, 2000.

UNAMUNO, Miguel de. Del sentimiento trágico de la vida. Madrid: Sarpe, 1984. (Los grandes pensadores).

UNWIN, Tim. El lugar de la geografia. Madrid: Cátedra, 1995.

VALDEÓN BARUQUE, Julio. La licenciatura de Historia en las universidades europeas del futuro. Íber didáctica de las Ciencias Sociales, Geografía e Historia, Barcelona, n. 42, año X, p. 68-75, octubre 2004. 
VERÍSSIMO, Luis Fernando. Misoginias. O Estado de S. Paulo. São Paulo, 9 nov. 2001. Caderno 2.

VILANOVAS RIBAS, Mercedes; MORENO JULIÀ, Xavier. Atlas de la evolución del analfabetismo en España de 1887 a 1991. Madrid: Centro de Publicaciones del Ministerio de Educación y Ciencia; CIDE, 1992. (Premios, 72). Disponível em: $<$ www.mepsyd.es/cide/espanol/publicaciones/colecciones/investigacion/col072/col07 2pc.pdf>. Acesso em: 22 set. 2008.

VIÑAO, Antonio. La educación comprensiva. Experimento con la utopía... tres años después. In: ALANÍS FALANTES, Leonardo (Coord.). Debate sobre la ESO: luces y sombras de uma etapa educativa. Madrid: Universidad Internacional de Andalucía / Akal, 2003. p. 35-66.

VIÑAO, Antonio. El éxito o fracaso de las reformas educativas: condicionantes, limitaciones, posibilidades. In: GIMENO SACRISTÁN, José (Comp). La reforma necesaria: entre la política educativa y la práctica escolar. Madrid: Ediciones Morata, 2006. p. 43-60.

THE WORLD BANK. World Development Report 2008: agriculture for development. Washington, DC: The World Bank, 2007. 


\section{Anexos}

\section{Anexo A - Anúncio do simulado aberto do Curso Anglo}

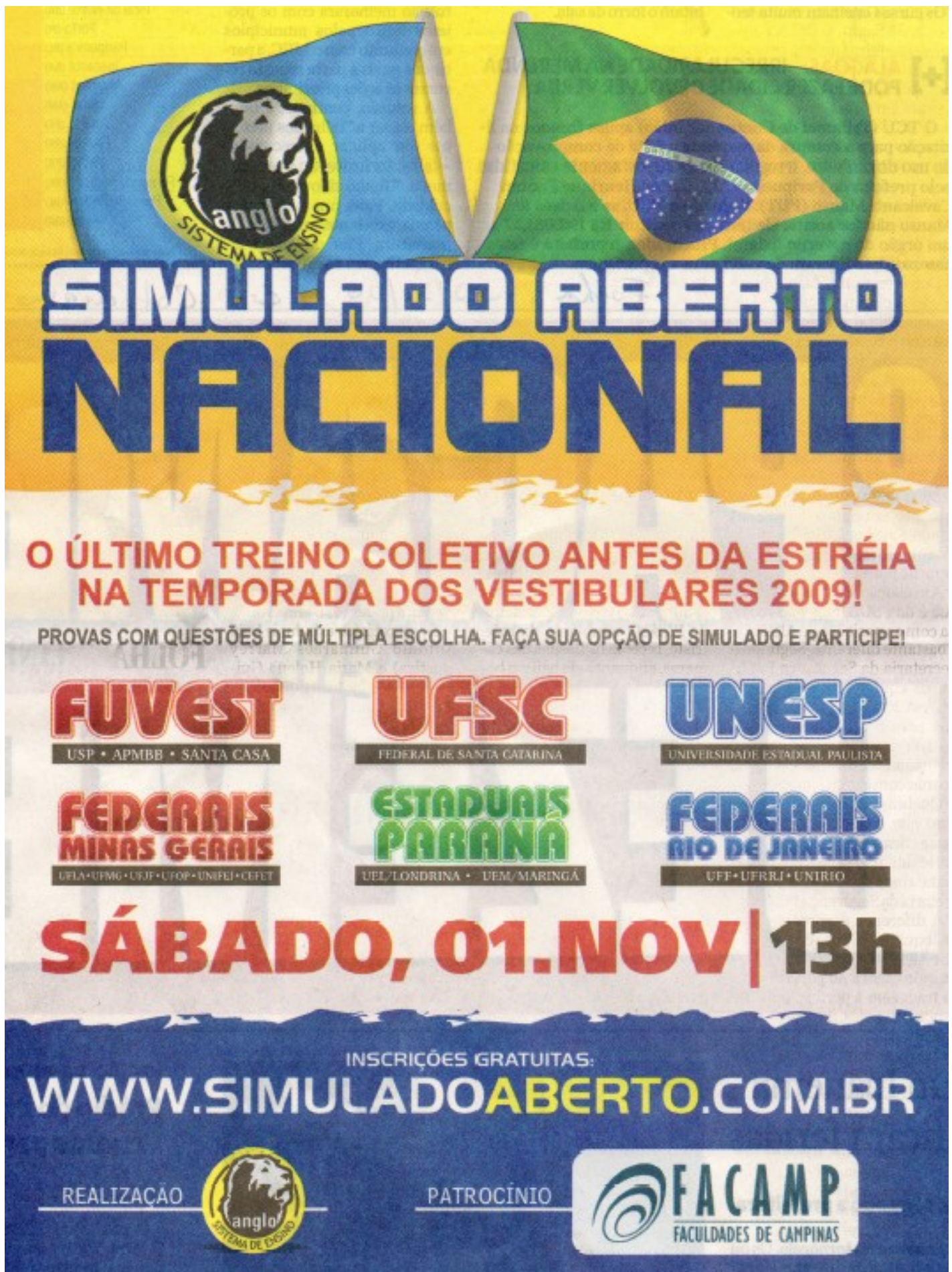

Fonte: Folha de S. Paulo, 22 out. 2008, p. C5. Cotidiano.

Obs. O Curso Anglo, sediado na cidade de São Paulo (SP), realizou no dia $1^{\circ}$ de novembro de 2008 o simulado aberto dos vestibulares de algumas das universidades públicas (federais e estaduais) mais concorridas do centro-sul do país. O interessante é que o patrocínio desta empreitada é de uma faculdade privada. 


\section{Anexo B - Eixos temáticos PCN+ Ensino Médio}

\begin{tabular}{|c|c|}
\hline \multicolumn{2}{|r|}{ Eixos temáticos } \\
\hline \multicolumn{2}{|r|}{ A dinâmica do espaço geográfico } \\
\hline Temas & Subtemas \\
\hline $\begin{array}{l}\text { 1. A fisionomia da } \\
\text { superfície terrestre }\end{array}$ & $\begin{array}{l}\text { - Tempo geológico; tempo histórico } \\
\text { - Dinâmica da litosfera. } 0 \text { relevo } \\
\text { - Dinâmica da superfície hídrica } \\
\text { - Os seres vivos e sua dinâmica }\end{array}$ \\
\hline $\begin{array}{l}\text { 2. As conquistas } \\
\text { tecnológicas e a } \\
\text { alteração do } \\
\text { equilíbrio natural }\end{array}$ & $\begin{array}{l}\text { - } 0 \text { ser humano, ser natural } \\
\text { - A cultura humana e suas conquistas } \\
\text { - Técnicas; tecnologia. Alteração da paisagem } \\
\text { - } 0 \text { ser humano e a utilização dos recursos naturais }\end{array}$ \\
\hline $\begin{array}{l}\text { 3. Ações em defesa } \\
\text { do substrato } \\
\text { natural e da } \\
\text { qualidade de vida }\end{array}$ & $\begin{array}{l}\text { - Os problemas ambientais e sua origem } \\
\text { - Grandes catástrofes ambientais e suas causas } \\
\text { - Consciência ambiental. Movimentos e mobilização } \\
\text { - Conferências internacionais. Resistência política. } \\
\text { Os caminhos do problema ambiental }\end{array}$ \\
\hline $\begin{array}{l}\text { 4. Informações e } \\
\text { recursos: } \\
\text { representação dos } \\
\text { fatos relativos à } \\
\text { dinâmica terrestre }\end{array}$ & $\begin{array}{l}\text { - Recursos disponíveis para o registro de problemas } \\
\text { ambientais } \\
\text { - Teledetecção: satélites a serviço da questão ambiental } \\
\text { - A produção cartográfica sobre a questão ambiental }\end{array}$ \\
\hline
\end{tabular}




\begin{tabular}{|c|c|}
\hline \multicolumn{2}{|c|}{0 mundo em transformação: as questões econômicas e os problemas geopolíticos } \\
\hline Temas & Subtemas \\
\hline 1. Um mundo que se abre & $\begin{array}{l}\text { - Redes, técnicas, fluxos } \\
\text { - O fim da Guerra Fria e a expansão do capitalismo } \\
\text { - A ONU como poder decisório em questão } \\
\text { - A moderna diplomacia }\end{array}$ \\
\hline 2. Um mundo que se fecha & $\begin{array}{l}\text { - Desenvolvimento e subdesenvolvimento: } \\
\text { distâncias que aumentam } \\
\text { - Blocos econômicos. Interesses políticos } \\
\text { - Nacionalismos e separatismos } \\
\text { - A América em busca de novos caminhos }\end{array}$ \\
\hline $\begin{array}{l}\text { 3. Tensöes, } \\
\text { conflitos, guerras }\end{array}$ & $\begin{array}{l}\text { - Oriente Médio } \\
\text { - A África: seus problemas e suas soluções } \\
\text { - Novos rumos do Leste Europeu } \\
\text { - Ásia do Sul e do Sudeste }\end{array}$ \\
\hline 4. Mapas, índices, taxas & $\begin{array}{l}\text { - Documentando o mundo político. Os mapas. Os gráficos } \\
\text { - Índices de desempenho e sua utilização } \\
\text { - A representação do local e do global } \\
\text { - O mapa como instrumento ideológico }\end{array}$ \\
\hline
\end{tabular}




\begin{tabular}{|c|c|}
\hline \multicolumn{2}{|c|}{0 homem criador de paisagem/modificador do espaço } \\
\hline Temas & Subtemas \\
\hline $\begin{array}{l}\text { 1. } 0 \text { espaço geográfico } \\
\text { produzido/apropriado }\end{array}$ & $\begin{array}{l}\text { - } 0 \text { espaço das técnicas: sistemas de objetos; sistemas de ações } \\
\text { - Fluxos, estradas, redes de comunicação } \\
\text { - A produção e o uso da energia } \\
\text { - Divisão internacional do trabalho e da produção }\end{array}$ \\
\hline 2. A paisagem rural & $\begin{array}{l}\text { - O meio rural tradicional } \\
\text { - O campo e a invasão do capital industrial } \\
\text { - Produção agrícola e tecnologia } \\
\text { - Produção agrícola e persistência da fome }\end{array}$ \\
\hline 3. A paisagem urbana & $\begin{array}{l}\text { - A cidade como espaço de transformação industrial } \\
\text { - A cidade prestadora de serviços } \\
\text { - Metrópoles. Metropolização } \\
\text { - Problemas urbanos. Serviços básicos na cidade }\end{array}$ \\
\hline $\begin{array}{l}\text { 4. A população mundial: } \\
\text { estrutura, dinâmica e } \\
\text { problemas }\end{array}$ & $\begin{array}{l}\text { - Ricos e pobres. A concentração das riquezas. A fome } \\
\text { e as doenças } \\
\text { - Etnias, religiōes, culturas } \\
\text { - Migrações. A população em movimento } \\
\text { - A população e o acesso aos bens produzidos }\end{array}$ \\
\hline
\end{tabular}




\begin{tabular}{|c|c|}
\hline \multicolumn{2}{|c|}{0 território brasileiro: um espaço globalizado } \\
\hline Temas & Subtemas \\
\hline $\begin{array}{l}\text { 1. Nacionalidade } \\
\text { e identidade cultural }\end{array}$ & $\begin{array}{l}\text { - População brasileira e sua identidade } \\
\text { - Crescimento populacional e dinâmica: migrações } \\
\text { - Urbanização. Periferização } \\
\text { - Transformações culturais da população brasileira } \\
\text { - As minorias étnicas e sua integração na sociedade brasileira }\end{array}$ \\
\hline $\begin{array}{l}\text { 2. A ocupação produtiva } \\
\text { do território }\end{array}$ & $\begin{array}{l}\text { - } 0 \text { campo brasileiro e suas transformações } \\
\text { - Os caminhos da industrialização brasileira } \\
\text { - } 0 \text { delineamento e a estrutura da questão energética no Brasil } \\
\text { - As cidades brasileiras e a prestação de serviços }\end{array}$ \\
\hline $\begin{array}{l}\text { 3. } 0 \text { problema das } \\
\text { comunicações num } \\
\text { território muito extenso }\end{array}$ & $\begin{array}{l}\text { - } 0 \text { modelo brasileiro de rede de transportes } \\
\text { - } 0 \text { transporte nas áreas urbanas e metropolitanas } \\
\text { - A circulação de valores e do pensamento. } \\
\text { O Brasil no contexto internacional } \\
\text { - Transportes, comunicações e integração nacional }\end{array}$ \\
\hline $\begin{array}{l}\text { 4. A questão ambiental } \\
\text { no Brasil }\end{array}$ & $\begin{array}{l}\text { - Os interesses econômicos e a degradação ambiental } \\
\text { - A degradação ambiental nas grandes cidades } \\
\text { - Dependência econômica e degradação ambiental } \\
\text { - O Brasil e os acordos ambientais internacionais }\end{array}$ \\
\hline
\end{tabular}

Fonte: Brasil (2002b, p. 66-68). 


\section{Anexo C - Competências e habilidades a serem desenvolvidas em Geografia: PCNEM}

\begin{tabular}{|c|c|}
\hline $\begin{array}{l}\text { Representação e } \\
\text { comunicação }\end{array}$ & $\begin{array}{l}\text { - Ler, analisar e interpretar os códigos específicos da Geografia } \\
\text { (mapas, gráficos, tabelas etc.), considerando-os como } \\
\text { elementos de representação de fatos e fenômenos espaciais e/ } \\
\text { ou espacializados. } \\
\text { - Reconhecer e aplicar o uso das escalas cartográfica e } \\
\text { geográfica, como formas de organizar e conhecer a } \\
\text { localização, distribuição e freqüência dos fenômenos naturais e } \\
\text { humanos. }\end{array}$ \\
\hline $\begin{array}{l}\text { Investigação e } \\
\text { compreensão }\end{array}$ & $\begin{array}{l}\text { - Reconhecer os fenômenos espaciais a partir da seleção, } \\
\text { comparação e interpretação, identificando as singularidades ou } \\
\text { generalidades de cada lugar, paisagem ou território. } \\
\text { - Selecionar e elaborar esquemas de investigação que } \\
\text { desenvolvam a observação dos processos de formação e } \\
\text { transformação dos territórios, tendo em vista as relações de } \\
\text { trabalho, a incorporação de técnicas e tecnologias e o } \\
\text { estabelecimento de redes sociais. } \\
\text { - Analisar e comparar, interdisciplinarmente, as relações entre } \\
\text { preservação e degradação da vida no planeta, tendo em vista o } \\
\text { conhecimento da sua dinâmica e a mundialização dos } \\
\text { fenômenos culturais, econômicos, tecnológicos e políticos que } \\
\text { incidem sobre a natureza, nas diferentes escalas - local, } \\
\text { regional, nacional e global. }\end{array}$ \\
\hline $\begin{array}{l}\text { Contextualizaçã } \\
\text { o sócio-cultural }\end{array}$ & $\begin{array}{l}\text { - Reconhecer na aparência das formas visíveis e concretas do } \\
\text { espaço geográfico atual a sua essência, ou seja, os processos } \\
\text { históricos, construídos em diferentes tempos, e os processos } \\
\text { contemporâneos, conjunto de práticas dos diferentes agentes, } \\
\text { que resultam em profundas mudanças na organização e no } \\
\text { conteúdo do espaço. } \\
\text { - Compreender e aplicar no cotidiano os conceitos básicos da } \\
\text { Geografia. } \\
\text { - Identificar, analisar e avaliar o impacto das transformações } \\
\text { naturais, sociais, econômicas, culturais e políticas no seu } \\
\text { "lugar-mundo", comparando, analisando e sintetizando a } \\
\text { densidade das relações e transformações que tornam concreta } \\
\text { e vivida a realidade. }\end{array}$ \\
\hline
\end{tabular}

Fonte: Brasil (1999, p. 69; 2002a, p. 315). 


\section{Anexo D - Competências e habilidades para a Geografia no ensino médio: OCEM}

\section{COMPETÊNCIAS}

- Capacidade de operar com os conceitos básicos da Geografia para análise e representação do espaço em suas múltiplas escalas.

- Capacidade de articulação dos conceitos.

- Capacidade de compreender o espaço geográfico a partir das múltiplas interaçōes entre sociedade e natureza.

- Domínio de linguagens próprias à análise geográfica.

- Capacidade de compreender os fenômenos locais, regionais e mundiais expressos por suas territorialidades, considerando as dimensöes de espaço e tempo.

- Estimular o desenvolvimento do espírito crítico

\section{HABILIDADES}

- Articular os conceitos da Geografia com a observação, descrição, organização de dados e informações do espaço geográfico considerando as escalas de análise.

- Reconhecer as dimensões de tempo e espaço na análise geográfica.

- Analisar os espaços considerando a influência dos eventos da natureza e da sociedade.

- Observar a possibilidade de predomínio de um ou de outro tipo de origem do evento.

- Verificar a inter-relação dos processos sociais e naturais na produção e organização do espaço geográfico em suas diversas escalas.

- Identificar os fenômenos geográficos expressos em diferentes linguagens.

- Utilizar mapas e gráficos resultantes de diferentes tecnologias.

- Reconhecer variadas formas de representação do espaço: cartográfica e tratamentos gráficos, matemáticos, estatísticos e iconográficos.

- Compreender o papel das sociedades no processo de produção do espaço, do território, da paisagem e do lugar.

- Compreender a importância do elemento cultural, respeitar a diversidade étnica e desenvolver a solidariedade.

- Capacidade de diagnosticar e interpretar os problemas sociais e ambientais da sociedade contemporânea.

- Capacidade de identificar as contradiçöes que se manifestam espacialmente, decorrentes dos processos produtivos e de consumo.

Fonte: Brasil (2006, p. 45). 
Anexo E - Enseñanzas Mínimas Real Decreto 1007/1991. Educación Secundaria Obligatoria. Ciencias Sociales, Geografía e História: contenidos

[textos a seguir]

Fonte: España (1991b, p. 42-44). 